\author{
Universidade de São Paulo - USP \\ Faculdade de Filosofia, Letras e Ciências Humanas \\ Departamento de Letras Orientais
}

HIROKO HASHIMOTO DA SILVA

\title{
A ESTÉTICA DO ESPAÇO NA OBRA PÔR-DO-SOL, DE DAZAI OSAMU
}

São Paulo, SP

2008 


\section{Hiroko Hashimoto da Silva}

\section{A Estética do Espaço na Obra Pôr-do-Sol, de Dazai Osamu}

Dissertação apresentada ao Departamento de Letras Orientais da Faculdade de Filosofia, Letras e Ciências Humanas da Universidade de São Paulo, como exigência parcial para obtenção do título de Mestre.

Área de concentração: Língua, Literatura e Cultura Japonesa.

Orientadora:

Prof. a Dra. Luiza Nana Yoshida 


\section{AGRADECIMENTOS}

À minha orientadora, Profa. Dra. Luiza Nana Yoshida, que me conduziu com muito profissionalismo, sabedoria, dedicação e paciência; pela possibilidade da troca de conhecimentos e experiências, que nortearam a minha busca e foram fundamentais para as análises e reflexões sobre a literatura e a cultura japonesa. Em especial, agradeço o incentivo e apoio dado, principalmente nos momentos de dificuldade, motivando-me à realização deste trabalho.

Aos Profs. Drs. Madalena Natsuko Hashimoto Cordaro, Homero Freitas de Andrade e Neide Hissae Nagae pela atenção dada nos momentos de incerteza, pelas sugestões e indicações de referências bibliográficas, que muito contribuíram para o aprimoramento das leituras e pesquisas desenvolvidas neste trabalho.

Ao Centro de Estudos Japoneses da Universidade de São Paulo (USP), e à Fundação Japão de São Paulo pela valiosa contribuição dada a esta pesquisa, através do acesso aos seus acervos bibliográficos, possibilitando assim a construção dos conhecimentos contidos neste estudo.

Ao amigo Pedro Moreira de Godoy pelo incentivo, paciência e apoio emocional, acima de tudo pelo auxílio técnico dado no uso das tecnologias da informação e comunicação, que muito permearam o trabalho de finalização do relato final da pesquisa e na execução das inserções das imagens no trabalho.

Ao marido José Antonio e filha Cintia pelo carinho e apoio concreto durante a minha trajetória; pela compreensão da ausência nos momentos de convívio familiar, nesses anos de dedicação aos estudos, que foram primordiais para que este trabalho de pesquisa fosse concluído a contento. 
Eu nunca guardei rebanhos, Mas é como se os guardasse, Minha alma é como um pastor, Conhece o vento e o sol E anda pela mão das Estações A seguir e a olhar.

Toda a paz da Natureza sem gente Vem sentar-se a meu lado.

Mas eu fico triste como um pôr-de-sol

Para a nossa imaginação, Quando esfria no fundo da planície

E se sente a noite entrada Como uma borboleta pela janela. 


\section{RESUMO}

SILVA, Hiroko Hashimoto da. A estética do espaço na obra Pôr-do-Sol, de Dazai Osamu. 2008. 255 f. Dissertação (Mestrado em Língua, Literatura e Cultura Japonesa) - Departamento de Letras Orientais, Faculdade de Filosofia, Letras e Ciências Humanas, Universidade de São Paulo, São Paulo, 2007.

Esta pesquisa visa analisar a estética do espaço e a estética literária empregadas na narrativa da obra Pôr-do-Sol, de Dazai Osamu, bem como resgatar a essência da cultura japonesa contemporânea de um Japão devastado pela Segunda Guerra Mundial, onde o autor expressa toda a sua sensibilidade poética. Este trabalho baseia-se na pesquisa biográfica de Dazai Osamu, com ênfase ao momento histórico que o autor testemunhou e onde realizou suas escritas, visando o levantamento da iconografia, pictografia e metonímia na linguagem de sua obra. Através deste estudo buscam-se os elementos que o enquadrem no gênero literário denominado Romance do Eu e as influências exercidas pelo Naturalismo europeu e movimentos sociais em sua carreira literária por meio da análise da hereditariedade, das influências do meio social no ambiente da obra e a estética literária empregada em sua técnica narrativa. O estudo desenvolvido demonstra as interferências ocidentais na Literatura Japonesa através da intertextualidade de obras japonesas e ocidentais, que dialogam entre si, e apresentam uma narrativa ao redor da estética do espaço na obra Pôr-do-Sol, retratando a essência humana, o irracional, as emoções, o onírico, as alegrias e desilusões inerentes a todos os seres humanos, principalmente na sociedade japonesa do período histórico do pós-guerra.

Palavras-chaves: Shayô. Estética do espaço. Estética literária. Romance do Eu. Literatura japonesa. 


\section{ABSTRACT}

SILVA, Hiroko H. Spatial aesthetics in Setting Sun by Osamu Dazai. 2008. 255 p. Dissertation (Master degree in Language, Literature e Japanese Culture) - Department of Orientals Literati, School of Philosophy, Literati e Human Science, Universidade de São Paulo (São Paulo University), São Paulo, 2008.

This research seeks analyze Dazai Osamu's spatial aesthetics and his literary style, which was used in his novel Setting Sun, besides to bring off essence of Japan Contemporary Culture, that was devastated in this country due to World War II. Another point of this study is the narrative aesthetics, where the writer expresses his poetic sensitiveness. This study is based on Dazai Osamu's autobiographic research, emphasizing a historical moment of Japan, which he witnessed and finished his writings despite of war; in his novel, Dazai aimed the language of: iconography survey, pictorial survey and metonymy language. This study will search for elements that fit in the literary genre named I Novel, as well as influences the writer suffered from European Naturalism and social movements in his literary carrier; Dazai analyzed the heredity and the influences of social means described in atmosphere of his work and the literary aesthetic (spatial) carried out in his narrative techniques. The study developed here points out western interference in Japanese literature, which can be noticed in the inter-textuality of literary works between west and east, that inter-act itself; therefore introduces a narrative related to spatial aesthetic in the Setting Sun which the writer describes the essence of human beings 'nature such as: irrational feelings, the emotions, the day-dreams, the cheerfulness and disappointments, inherent in whole human beings, especially in the Japanese society in certain historical time after war.

Keywords: Setting Sun. Aesthetic spatial. Literary aesthetic. I Novel. Japanese literature. 


\section{LISTA DE ILUSTRAÇÕES}

Figura 01 Dazai: vida e obra ................................................................... 38

Figura 02 Árvore genealógica da família Tsushima ................................... 40

Figura 03 Foto da Família Tsushima ........................................................ 41

Figura 04 Monte Iwaki visto do Castelo de Hirosaki ....................................... 42

Figura 05 Rota de Dazai: o retorno a Tsugaru .......................................... 52

Figura 06 Take com idade avançada ...................................................... 54

Figura 07 Nakamura Teijirô, Koshino Take e Nakabata Keikichi no Memorial de Dazai ..................................................... 57

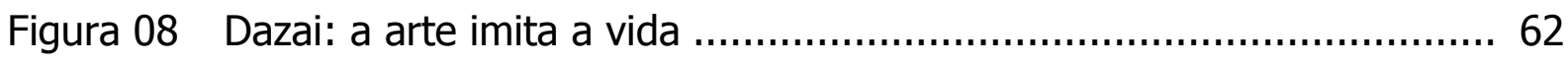

Figura 09 Desqualificado Como Ser Humano (Ningen Shikkaku)...................... 64

Figura 10 Jardim do Pôr-do-Sol, na antiga casa de Dazai................................ 68 


\section{SUMÁRIO}

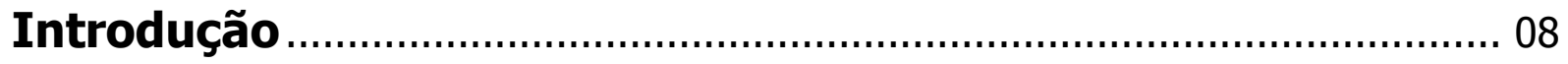

\section{Capítulo I}

\section{Panorama Histórico-Literário do Pós-guerra}

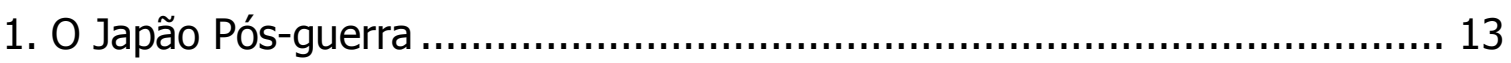

2. O Surgimento dos Romances do Pós-guerra ............................................. 21

3. Dazai Osamu e a Burai-ha (Corrente dos Decadentes) ............................. 28

4. Dazai Osamu e o Romance do Eu ............................................................ 31

\section{Capitulo II}

Dazai Osamu: vida e obra

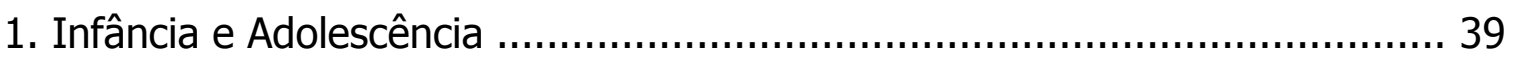

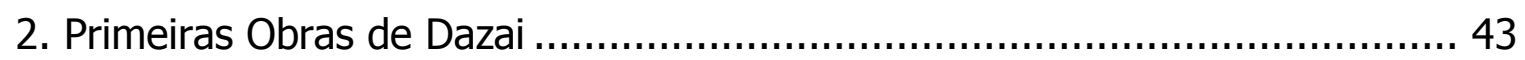

3. Consolidação como Escritor e Atividades Durante a Guerra ..........................45

4. Retorno para Tsugaru: o cronotopo de Dazai ........................................ 52

5. Atividades no Pós-guerra ......................................................................... 58

\section{Capítulo III}

\section{Análise da Estética do Espaço em Pôr-do-Sol}

1. Análise do Espaço e do Tempo ................................................................ 70

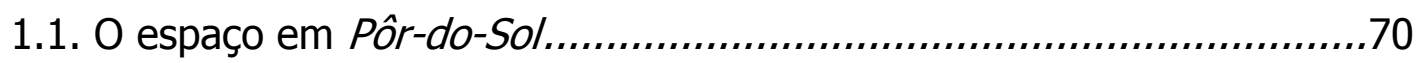

1.2. O tempo em Pôr-do-Sol................................................................ 79

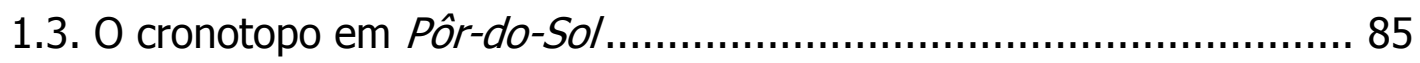

2. Análises dos Elementos Estéticos............................................................ 93

2.1. A estética dos elementos simbólicos em Pôr-do-Sol........................ 93

2.2. A estética do espaço pictórico e poético em Pôr-do-Sol.................. 105

2.3. A estética do espaço musical em Pôr-do-Sol................................. 119

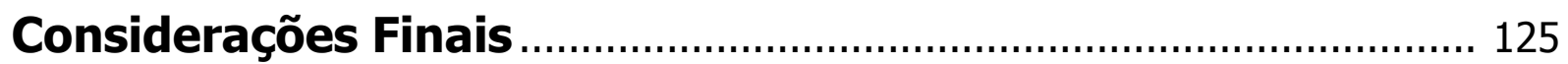

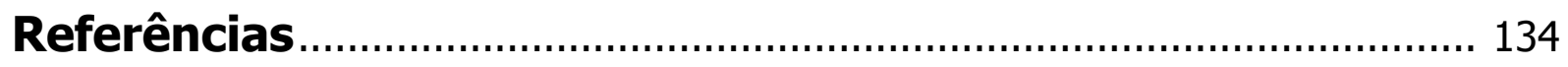

Apêndices

Apêndice A - Cronologia da Vida de Dazai Osamu e suas obras ....................144

Apêndice B - Tradução da Obra Shayô (Pôr-do-Sol) ......................................164 


\section{Introdução}

Ao iniciar a pesquisa para a escolha dos modernos autores literários japoneses, deparei-me com uma grande incerteza. Essa incerteza recaía sobre a escolha de um autor que representasse o Japão do período pós-guerra, mas que traduzisse em linguagem universal a literatura desse período e que estivesse dentre os escritores renomados no mundo literário japonês, desde os laureados pelo prêmio Nobel de Literatura, como Kawabata Yasunari e Kenzaburo Ôe, do eixo Yamato ou Hondo (ilha principal), aos diversos escritores representativos da literatura Okinawana, também já laureados com o prêmio literário Akutagawa, como Ôshiro Tatsuhiro e Matayoshi Eiki

Inicialmente, buscava-se um autor que pudesse despertar grande interesse por parte dos aficionados pela cultura japonesa e do público em geral. Sendo assim, a escolha se deu pelas obras de Dazai Osamu, tanto por ele representar o período pós-guerra quanto pela riqueza literária de sua obra, pouco conhecida no Brasil. Sua obra Shayô (Pôr-do-Sol) causou grande impacto no Japão Pós-Guerra e é também sua única obra que foi traduzida para o português por Antonio Nojiri, em 1974.

Apesar da sua curta trajetória de vida, Dazai conseguiu se sobressair como um dos maiores escritores modernos da Literatura Japonesa. Pela sua versatilidade em descrever o atormentado espírito do ser humano, segundo Phyllis Lyons (1985), ele pode ser igualado a Dostoiévski.

Durante a Segunda Guerra Mundial, era comum que os escritores japoneses, mesmo os renomados, não conseguissem publicar suas produções devido ao racionamento de recursos financeiros e materiais. Para Dazai, no entanto, a guerra constitui período de intensa atividade literária. Foi durante a guerra que Dazai reescreveu Otogizôshi (Fábulas), cujas narrativas originais foram escritas no período Muromachi (1392-1573). Otogizôshi é uma compilação de quatro contos: Kobutori 
Jiisan (O Removedor de Calombos), Kachikachi Yama (A Montanha Crepitante), Shitakiri Suzume (O Pardal da Língua Cortada) e Urashima San (O Senhor Urashima).

As narrativas acima foram produzidas num abrigo antiaéreo durante o conflito mundial, atendendo a solicitação da filha, que lhe pedira uma leitura para entretê-la. Embora na criação de suas obras no pós-guerra ele tenha conseguido captar a atmosfera vívida da derrota, seus romances e contos são atemporais, na medida em que, através de sua sensibilidade, descrevem a situação do indivíduo que busca encontrar o seu próprio caminho em seu próprio tempo e lugar.

Pôr-do-So/foi escrito após a derrota do Japão, quando o país ainda estava sob a ocupação de tropas norte-americanas, e publicado em 1947. Nele temos retratado o período de decandência da sociedade japonesa no pós-guerra e encontramos na leitura uma nação deprimida, em ruínas, testemunhando o declínio de sua classe aristocrática. Essa situação é personificada por meio de uma família que representa o declínio das conseqüências financeiras, políticas, literárias e espirituais. Dazai descreve a desagregação dessa família e o destino de cada um dos membros diante de uma nova situação social que se vêem obrigados a enfrentar. Alguns desses personagens, como Uehara e Naoji, buscam na decadência a solução de seus problemas, enquanto outros, como Kazuko, apóiam-se no amor e na revolução.

Atualmente, no Japão, existem várias versões de Shayô contendo notas comentadas com a interpretação das idéias de Dazai pela visão de diversos críticos. A obra foi traduzida para o inglês como The Setting Sun, por Donald Keene, em 1981, objetivando uma maior divulgação da cultura do povo japonês junto ao público americano e enfatizando a importância de Dazai na Literatura Japonesa.

Segundo Keene (1981),

[...] Pôr-do-Sol não pode ser considerado como um documento sociológico de ajuda àqueles que desejam conhecer mais sobre um obscuro ou distante país. É um poderoso e belo romance, de um dos mais brilhantes recentes escritores japoneses, e permance como tal no mundo da literatura. (KEENE, 1981, p. xvi, tradução nossa) 
Após a leitura de Pôr-do-Sol, de Antonio Nojiri, e ao tomar contato com a tradução de Donald Keene, consideramos de suma importância um aprofundamento da análise das obras de Dazai. O objetivo inicial da pesquisa, em um primeiro aspecto, era o de fazer a divulgação da cultura japonesa no Brasil mediante o resgate histórico da literatura moderna do Japão, pesquisando suas tendências e influências, e num segundo aspecto, o aprofundamento da linguagem estilística de Dazai Osamu, bem como traçar o perfil do autor e de sua obra.

Percebe-se que o estilo de Dazai em Pôr-do-So/trazia com riqueza de detalhes os elementos da natureza: flores, signos da cultura japonesa, as estações do ano em um movimento cíclico (temporal), nascimento, vida e morte. Esses elementos são a recriação lingüística do autor e descrições do pano de fundo do cenário da trama, e por isso era necessário comprovar se essa estética do espaço, verificada em Pôr-doSol, fazia parte do estilo literário do autor e se havia influências do Impressionismo. Em outro aspecto, era preciso verificar o porquê dos estrangeirismos e citações de vários autores europeus e de elementos do Cristianismo, que não faziam parte da cultura japonesa naquele momento, estarem presentes na obra.

A presente pesquisa visa destacar a sensibilidade poética de Dazai Osamu ao descrever a natureza, a estética do espaço e a essência humana de seus personagens em Pôr-do-Sol, fundamentadas pelas influências que o autor teve em sua técnica narrativa. Há citações de Jardim das Cerejeiras e Gaivota, de Anton Tchekhov, na obra Pôr-so-Sol, e segundo Yanagi Tomiko (1970), Dazai utilizou-as como inspiração. Em outros momentos, Dazai recorre à obra de Michelângelo, para expressar a beleza feminina, e alguns críticos, como Jinzai Kiyoshi (1968), afirmam que sua obra possui musicalidade e a associam a um Quarteto de Cordas, de Mozart.

A pesquisa faz também referências à influência do gênero literário Watakushi shôsetsu ou Shishôsetsu (Romance do Eu), pertencente à forma narrativa da literatura moderna e contemporânea japonesa, na qual o autor insere aspectos autobiográficos. Nessa obra, Dazai faz uso de recursos da literatura clássica japonesa denominada Nikki bungaku (Literatura de Diários), citando os Yûgao Nikki (Diário de 
Yûgao) e Sarashina Nikki (Diário de Sarashina). Nessa narrativa, além dos diários, faz uso de cartas e testamento como se fossem os elos entre o passado e o presente.

Segundo Kenne (1981, p. xi, tradução nossa), "o autor Dazai Osamu recorria a vários tipos de técnicas de flashback (incluindo diários, cartas e testamento) para criar para o leitor figuras tridimensionais". Esse recurso, em que o autor recorre ao passado para explicar o presente, é analisado pela estética literária como cronotopo (tempo-espaço). Assim, o uso do cronotopo reforça a estética do espaço existente em Pôr-do-Sol, tornando-a, para o leitor, um ambiente mental quadridimensional.

Inicialmente, a metodologia embasou-se na pesquisa teórico-bibliográfica através da leitura e tradução da obra Shayô, organizada e compilada por Ito Sei e publicada em 12 de setembro de 1957 pela Editora Shûeisha, de Tóquio, em sua primeira edição, obra esta que compõe uma compilação de várias obras de Dazai. $\mathrm{A}$ escolha se deu pelo fato de que esta foi a versão do original mais antigo a que se teve acesso, ou seja, dez anos após a publicação do original, e por conter notas comentadas, explicativas e interpretativas das idéias contidas na obra, o que muito nos ajudou na análise e tradução. Por precaução, foi comparada com outras leituras da mesma obra, sendo: Pôr-do-Sol (DAZAI, 1974), em português, tradução de Antonio Nojiri; The Setting Sun (DAZAI, 1981), em inglês, tradução de Donald Keene; e Shayô (DAZAI, 1969, 1979), em japonês, organizado pela Editora Shinchô. As notas comentadas de Ito Sei forneciam dados significativos para decifrar os termos empregados por Dazai que não eram comuns ao público japonês da época, por esse motivo, foram mantidas na tradução, pois julgamos serem também importantes para a compreensão do público brasileiro.

Em uma segunda fase, foi elaborado um panorama histórico-literário, no qual se encontram alicerçados o processo de criação do autor e suas influências. Esse estudo também abrangerá a pesquisa autobiográfica, relacionando-a com o momento histórico em que o autor realizou seus escritos, para estabelecer possíveis conexões entre seu estilo literário, seus personagens e a vida do autor, principalmente em relação à análise da obra Pôr-do-Sol. Haverá ênfase também para a descrição do universo feminino das personagens Kazuko e sua mãe, devido ao fato 
de terem seus hábitos descritos por Dazai com muita desenvoltura, como se ele tivesse o conhecimento da alma humana feminina.

Em uma terceira fase, foi feita a busca de diversos autores da teoria literária e estética literária, buscando o embasamento dos seguintes aspectos: a natureza, o tempo e o espaço, cronotopo, por Mikhail Bakhtin (2000); o tempo no romance, por Jean Pouilon (1974); a natureza, o Naturalismo, o Impressionismo e a musicalidade, por Arnold Hauser (2003); a tipologia do romance, por Wolfgang Kayser (1958); as categorias da narrativa literária, por Tvetan Todorov (1971); os elementos da natureza (ar, água, fogo e terra) e o espaço poético, por Betina Cunha (2000) e Gaston Bachelard (1978); entre outros autores. Buscou-se, assim, a fundamentação teórica para melhor compreensão da relação entre natureza (espaço) e homem como a possível influência na construção das imagens, figuras tridimensionais, na obra Pôrdo-Sol.

Os métodos de pesquisa aplicados buscaram trazer à tona a estética do espaço, o tema central do trabalho, mas nem por isso ignoraram os aspectos que influenciaram a obra e seu processo de composição. Nenhum elemento da narrativa pode ser analisado isoladamente, pois todos estão interligados para resultar numa unidade que torna forma e conteúdo indissociáveis. E assim, apresentamos o trabalho estruturado em três capítulos, sendo: Capítulo I - Panorama HistóricoLiterário do Pós-Guerra; Capítulo II - Dazai Osamu: Vida e Obra; e Capítulo III Análise da Estética do Espaço. 


\section{Capítulo I}

\section{Panorama Histórico-Literário do Pós-Guerra}

\section{O Japão do Pós-guerra}

De acordo com Shuichi Kato (1979), nos anos posteriores ao final da Segunda Guerra Mundial aconteceram grandes mudanças no cenário político-social japonês sob o jugo das forças de ocupação americanas. Uma das mudanças ocorridas na época foi a desmilitarização do Japão, imposta pelos americanos e caracterizada no Art. 90 da nova Constituição no que tange o tratado de paz. Outra mudança foi a democratização do estado burocrático imperial, com a restrição do poder legal do Imperador, além da instituição da democracia parlamentar, a garantia de liberdade de atividades para os partidos políticos e a garantia de liberdade de expressão. Contudo, essas mudanças abruptas no sistema político não foram acompanhadas pelas mudanças no comportamento e na consciência política. O relacionamento entre as províncias e capital ainda permanecia com todas as características do centralismo, que havia começado no governo Meiji, e a autonomia local permanecia fraca.

A mudança mais considerável ocorrida desde 1945 se deu na vida social, com a propagação do igualitarismo e o relaxamento da rigorosa hierarquia seguida pelas famílias, escolas, empresas e outras organizações. A sociedade japonesa permaneceu um grupo unido desde a guerra. Mas, ao mesmo tempo, permanece altamente igualitária, com intenso senso de competição entre grupos e grupos de membros individuais e também com forte tendência para a integração do indivíduo dentro do grupo.

A grande mudança nas relações exteriores tem sido o relacionamento com os Estados Unidos desde a ocupação. A influência marcante dos americanos tem surtido efeito em quase todas as áreas, como política, economia, relação militar, informação, 
escolaridade e cultura popular. O Japão nunca tinha sido influenciado tão amplamente por um país estrangeiro antes da guerra. A influência da China sobre 0 Japão antigo era ampla e profunda, mas não era marcada por pressões econômicas nem políticas por parte da China. Quando o Japão abriu os portos no século XIX, estava sob pressão militar, mas o processo de ocidentalização que se seguiu não foi adequado como modelo de um país avançado. Essa ocidentalização não afetou significativamente o modo de vida das massas, diferente do que ocorreu desde a guerra.

É possível considerar a história da economia do pós-guerra japonesa como sendo dividida em duas fases. Os primeiros quinze anos foram um período no qual a economia japonesa foi beneficiada pela ajuda americana. Mais tarde, foram as condições econômicas criadas pelo conflito coreano que ajudaram a recuperar os prejuízos ocorridos com a devastação causada pela Guerra do Pacífico. Após o isolamento de anos de guerra, havia considerável curiosidade dos japoneses sobre as obras ocidentais. As traduções de livros europeus e americanos eram largamente lidas.

O segundo período de quinze anos foi de rápido crescimento para o comércio além-mar, e o mercado doméstico para produtos industriais expandiu dramaticamente, o que fez com que o padrão de vida dos japoneses se elevasse. Havia televisores em quase todos os lares, e muitos cidadãos possuíam carro próprio. Havia turistas estrangeiros por toda parte. Ao mesmo tempo, os japoneses demonstravam menos interesse em traduções literárias, sobretudo pelos intelectuais ocidentais. Esse era o período da Guerra do Vietnã e do movimento estudantil de esquerda, que chamou a atenção da juventude.

A Literatura Japonesa foi vigorosa na primeira metade desses trinta anos, 0 período de recuperação econômica, mas perdeu seu vigor criativo na segunda metade, o período economicamente próspero. Em contraste, a Alemanha - outra nação derrotada - se recobrou rapidamente em termos econômicos após a guerra, mas quase paralisou sua atividade criativa durante esse período. Foi só a partir dos anos '60 que a atividade criativa alemã começou a florescer no campo da literatura e 
das artes. Os fatores que condicionaram a Literatura Japonesa no período pós-guerra foram, no primeiro período, a experiência pessoal da guerra e a experiência de o país se abrir para outros países, e, depois de 1960, a Guerra do Vietnã e o alto crescimento dos consumidores da sociedade.

\section{Renovação na cultura}

O longo processo de renovação dos sistemas social, tecnológico, industrial e dos métodos acadêmicos do Japão foi baseado em modelos ocidentais e começou com a Restauração Meiji (1868-1912). Esse processo significou, para os japoneses, a assimilação de um grande número de conceitos traduzidos de linguagens ocidentais, e, ao mesmo tempo, criou nos japoneses o hábito da utilização da sociedade ocidental como um parâmetro quando se referissem à história da sociedade japonesa. O supernacionalismo japonês diminuiu após a guerra e intensificou a curiosidade e reflexão dos japoneses sobre o entendimento da cultura ocidental. Entre os temas para a reconsideração da cultura ocidental estavam as diferenças entre conceitos traduzidos para o japonês e o mesmo conceito expressado na linguagem original (estrangeira). $O$ entendimento dos conceitos estrangeiros pelos japoneses esbarrava na fraqueza de conexão entre o povo japonês e os sistemas intelectuais que eles (japoneses) tinham importado, fato que ocorria devido à falta de experiência direta com a sociedade ocidental que tinha produzido o pensamento.

Diante da falta de intercâmbio cultural com o Ocidente, foi necessário que o Japão se aproximasse da cultura ocidental. Essa aproximação cultural foi adotada com entusiasmo pelo escritor Mori Arimasa (1911-1976). Em 1950, Mori mudou-se de Tóquio para Paris, aos quarenta anos, com o intuito de estudar Descartes. 0 primeiro contato dele com a sociedade ocidental foi um "choque cultural". Com o passar do tempo, ele conseguiu superar esse choque adotando o seu lema, que era o de não explicar conceitos franceses baseados na sua experiência japonesa - que poderia ser uma mera tradução. O que ele fez foi compreender os conceitos franceses através das suas experiências oriundas da cultura francesa. Em sua obra 
Tôzakaru Nôtorudamu (Notre Dame Mais Distante, 1974), ele relata a dificuldade de compreender a cultura francesa e as suas experiências na França. Ele relata também quais as partes que ele considerou serem mais decisivas em relação aos contatos com a cultura estrangeira. Além desse trabalho, Mori escreveu os romances Babiron no Nagare no hotori nite (Pelas Águas de Babilônia, 1957) e Harukanaru Nôtorudamu (Remota Notre Dame, 1976). Esse último foi escrito em um estilo lírico e incisivamente analítico.

No Japão pós-guerra não faltaram escritores que absorvessem a herança literária da Europa Ocidental. Muitos escritores e dramaturgos encontraram apoio dos literatos ocidentais para produzir trabalhos criativos na tradição japonesa. Um desses exemplos pode ser o dramaturgo Kinoshita Junji (1914 ---). Para a criação de seu trabalho ele combinava o aprendizado adquirido através da moderna dramaturgia européia. Kinoshita tinha grande familiaridade com o folclore japonês. Com base nessa experiência ele produziu uma das peças teatrais mais bem sucedidas no Japão, Shigosen no Matsuri (Festival de Meridiano), primeira peça apresentada em 1979.

Além desses escritores, outro literato que se destacou nesse período foi Terada Tôru (1915 ---). Enquanto ele assimilava a literatura francesa, concentrava sua atenção também na cultura japonesa, particularmente na figura do monge budista da Idade Média Dôgen. Terada, em sua peça teatral Dôgen no Gengôchû (O Universo Lingüístico de Dôgen, 1974), examinou o relacionamento inseparável entre o pensamento e personalidade. Um dos pontos altos da crítica literária do pós-guerra é o produto da fusão dessas duas aproximações que Dôgen faz em seu trabalho. Há vários outros escritores que se destacaram nesse período pós-guerra como sendo testemunhas da nova onda de abertura cultural não somente com o Ocidente, mas com a China também.

Outro romancista pós-guerra que se destacou na Literatura Japonesa foi Nakamura Shin'ichirô (1918-). Em 1957, ele produziu um trabalho baseado na Literatura Heian, além de diversos romances. Em 1971, ele concluiu o romance Rai San'yô to Sono jidai (Rai San'yô e Sua Época). Esse é um trabalho que mostra a 
influência de Marcel Proust (1871-1922). Os personagens de Proust freqüentavam os salões refinados da época. A similaridade desse refinamento, comparada em termos de época, segundo Nakamura pode se igualar ao Japão do final do período Tokugawa (1603-1868), porque a vida e costumes da Tóquio contemporânea são deselegantes e emergidas das cinzas de destruição da guerra, e a cidade é totalmente avessa à época de salões refinados de Proust.

O envolvimento dos escritores (Kinoshita, Terada e Nakamura) com a cultura ocidental é profundo, apesar de eles terem feito opção pela tradição literária japonesa. Cada um desses autores trilhou o seu próprio caminho. Como exemplo, a preocupação de Terada era com os trabalhos escritos de Dôgen, o interesse de Kinoshita recaía sobre o folclore japonês, e o de Nakamura era com as Narrativas de Genji (literatura clássica japonesa).

Outro romancista japonês que teve seu trabalho e pensamento diretamente influenciados pelas escritas dos EUA foi Tsurumi Shunsuke (1922-). Tsurumi foi residir nos EUA ainda jovem, em 1938. Após a conclusão universitária por lá, ele retornou ao Japão durante a Guerra do Pacífico (Segunda Guerra) juntamente com outros compatriotas repatriados. Tsurumi, em seu livro Nihon Shisô no Kanôsei (As Possibilidades de Pensamento dos Japoneses, 1964), justifica o seu retorno para a terra natal declarando o seu sentimento de que no tempo da derrota, seu lugar era no Japão. Esse sentimento de nacionalismo foi traduzido por Tsurumi como sendo a realização de que havia somente um lugar para trabalhar para aqueles que se associaram com a linguagem e cultura japonesas.

Não foram somente intelectuais urbanos e os pseudo-intelectuais que se juntaram devido à linguagem e cultura japonesas. Todos os cidadãos comuns que sentiam orgulho de serem japoneses também aderiram ao movimento. Para Tsurumi, não importava a sua experiência acumulada na América, ele estava preocupado com a sociedade contemporânea japonesa. Ele discutia sobre o seu país com seus compatriotas de uma maneira positiva, defendendo os trabalhos de todos os intelectuais japoneses. Ele argumenta ser particularmente difícil escrever liricamente 
em japonês, mas isso não significa que seja fácil escrever com rigor intelectual. 0 estilo literário de Tsurumi contribuiu para a prosa japonesa.

Pode ser destacado, dentro do cenário literário japonês do pós-guerra, o escritor que testemunhou a abertura do Japão para o Ocidente e para a China, Takeuchi Yoshimi (1910-1977). No seu trabalho Hyôronshû (Coletânea de Críticas), publicado em 1966, o autor relata, através da China, a sua visão da moderna história do Japão. Em 1948, Takeuchi escreveu Chûgoku no Kindai to Nihon no Kindai (Era Moderna Chinesa e Era Moderna Japonesa). Nesse trabalho o autor aponta a diferença existente entre a China e o Japão. A China resistiu e rejeitou a cultura ocidental, ao passo que o Japão, desde a Restauração Meiji, aceitou sem resistência a cultura ocidental. $O$ Japão planejou a sua modernização baseada nessa política, tornando-se, assim, um imperialismo japonês. Takeuchi criticava a burocracia e o conservadorismo acadêmico japonês, além das atitudes dos líderes do Partido Comunista japonês.

\section{O rápido crescimento japonês e a sociedade controlada}

A recuperação econômica japonesa foi seguida pela expansão econômica através dos anos '60 e '70. Nesse período houve o decréscimo de trabalhadores rurais e a expansão de assalariados urbanos no país. A sociedade privilegiava a prosperidade econômica, particularmente a indústria. A rápida expansão nesse setor tem chamado a atenção de alguns escritores e de grupos minoritários de cidadãos, levantando dúvidas e críticas sobre a sociedade como um todo. As atitudes deles revelam nostalgia em relação ao tempo anterior à democratização do país. A democratização do Japão, na visão dos escritores tradicionais, deveria ser levada a sério, porque "os bons e velhos tempos" e as democracias significam coisas diferentes para diferentes pessoas.

Dentre os escritores que estavam protestando contra a ocidentalização e pregando o retorno ao Japão tradicional estava Yukio Mishima (1925-1970). Ele foi o exemplo extremo de manifestação da resistência conservadora diante das rápidas 
transformações do país. Para demonstrar a sua insatisfação, ele cometeu seppuku (suicídio de acordo com o código samurai; abrir o abdômem com uma espada) diante da mídia, em 1970, dentro de um quartel general. Mishima havia nascido em 1925, em plena efervescência do nacionalismo japonês. Seu suicídio expressa a dificuldade de muitos japoneses em conviver com os paradoxos do Japão do pósguerra. Para Mishima, "os bons e velhos tempos" significavam os anos '30, a era em que o Imperador japonês era considerado divino e era o centro da unidade cultural.

Outro escritor que descreve a instabilidade do sistema social existente após 1960 é Ôe Kensaburô (1935-). Em seus trabalhos Hiroshima Nôto (Notas de Hiroshima, 1965) e Okinawa Nôto (Notas de Okinawa, 1970), Ôe questiona sobre as vítimas das bombas e as sociedades locais esmagadas pela guerra, assim como o estabelecimento de bases americanas - em outras palavras, o Terceiro Mundo dentro do Japão.

\section{Modernização pós 1945}

As publicações literárias durante a guerra foram reduzidas drasticamente devido à falta de recursos financeiros e materiais, situação que se agravou com a destruição das indústrias de publicação que estavam concentradas em Tóquio. Com o término da guerra, muitas editoras foram se reerguendo rapidamente, aproveitando a euforia da ocupação americana e da liberdade de expressão. A expressão apropriada para esse período seria "vida nova", com a restauração da política e da literatura da esquerda, que havia sido brutalmente reprimida nos anos '30. Com certeza, a política da ocupação dos Estados Unidos foi benéfica para a mobilização dos escritores de esquerda que haviam sido desmantelados. Esses mesmos escritores eram gratos pela ocupação pela sua benevolência em patrocinar a liberdade e ideais de democracia.

Segundo afirma Alan Wolfe (1990): 
Isso não significava que todos os líderes da esquerda literária eram nacionalistas. As reações dos intelectuais contra a guerra eram complexas. Nas reuniões, estavam em pauta a derrota e a presença americana. Esses temas refletiam em intensos debates sobre a responsabilidade da guerra nas relações culturais e políticas, e também sobre devassar a ficção agridoce que procurava exorcizar a culpa advinda do orgulho. Essas reflexões intensas, contudo, eram atribuídas somente aos intelectuais, e não à população. Alavancado pela recuperação do material literário, o humor popular tinha sido direcionado, especialmente, para a perspectiva do milagre do Japão do pós-guerra, retratado como um desenvolvimento otimista. Apesar de a economia japonesa ter sido afetada por uma desastrosa inflação e assombrada pelo espectro da fome, o alívio do povo por conviver com um Estado sem guerra e pelo retorno da vida quotidiana, da normalidade, forneceu um senso de esperança em relação às novas oportunidades. (WOLFE, 1990, p. 173, tradução nossa)

A recuperação da indústria de publicação, apesar de sua quase dizimação pela guerra e da escassez dos produtos básicos, incrementou a expansão de novos jornais com títulos sintomáticos de ânimos como Vida Nova, Novo Japão, Nova Humanidade, Liberdade, Revolução. Além de tudo, aos editores foi dada a permissão para criticar ou escrever sobre diversos temas, desde o Imperador até assuntos relacionados ao sexo, exceto falar da ocupação em si. O público respondia com apetite voraz pela leituras, como se isso compensasse a falta de comida.

Na realidade, as mudanças impostas pela ocupação tinham afetado somente áreas restritas da vida do povo em relação ao trabalho e ao lazer. $O$ intuito agora era restabelecer a vida diária familiar. Na literatura, a preferência dos editores e leitores estava focada na família. O expurgo dos escritores que colaboraram com a propaganda da guerra levou três anos para a preparação, período que coincidiu com a expulsão dos colaboradores da guerra ou de quem ignorou o crescente poder dos ex-líderes zaibatsu (acordo financeiro) ${ }^{1}$. Com certeza, o curso inverso estava reassumindo o poder dos elementos expurgados no tempo. $O$ ânimo dos céticos agora sinalizava que a restauração democrática estava por um fio.

\footnotetext{
${ }^{1}$ Aliança entre governo e famílias ricas; dinheiro em troca de ajuda governamental. Ex: Mitsubishi.
} 
Renovação na economia

No rol das reformas estavam ainda a reforma agrária e a redefinição dos zaibatsu. Com as novas regras para o campo, as terras nas quais os proprietários não residiam ou que ultrapassavam em tamanho o limite de referência foram compradas compulsoriamente pelo governo. Assim, as grandes propriedades foram divididas, e o poder de seus proprietários diminuiu consideravelmente. Com essas medidas, novos pequenos proprietários ajudaram a criar alicerces para a formação de um mercado interno estável.

Com relação aos zaibatsu, as forças de ocupação exigiram a quebra da hegemonia das famílias poderosas nos cargos de direção dos conglomerados. A partir daí, como na burocracia do Estado, as empresas privadas também sofreram uma espécie de expurgo de elementos agora indesejáveis. A idéia era diminuir a força política dos conglomerados, pois até o final da guerra haviam contribuído de muitas formas para a definição dos destinos do país graças à concentração do poderio econômico. Seus interesses é que haviam empurrado os exércitos japoneses em varias direções na Ásia. Com as novas normas, sua força se diluiu. Em julho de 1947, foi instituída a Lei Anti-Monopólio, com a qual os conglomerados apenas se tornaram matrizes de referência para pequenas empresas prestadoras de serviço, cada uma com gestão própria. Elas se especializaram na fabricação de algum componente ou de um setor da produção, que era então vendido à matriz. Essa forma de administração prosseguiria nas décadas seguintes, sendo, a partir de então, uma das características do modo japonês de gerir negócios.

\section{O Surgimento dos Romances do Pós-Guerra}

Para compreender a aura psicológica das personagens da obra analisada, fazse necessário uma revisitação ao período de intensas buscas ideológicas e de 
decadências financeiras e morais. Embora o tema seja o espaço, ou mais precisamente a estética desse espaço, a pesquisa pretende tocar, ainda que sutilmente, o modelo social em que as personagens poderiam estar inseridas.

Kazuko, a narradora-protagonista de Shayô presenciou importantes alterações históricas, e Dazai era um autor muito voltado para as questões do seu tempo e de seu país. Tais informações levam a crer na influência do espaço ideológico nas opções estéticas feitas pelo autor para descrever o espaço físico.

Com o final da Segunda Guerra, em 15 de agosto de 1945, o povo japonês evitava usar a palavra haisen (derrota), substituindo-a por shûsen (término da guerra). Os dois anos do pós-guerra foram um período de extraordinária atividade literária, que havia sido limitada durante o período de conflito.

Em conseqüência do conflito havia o racionamento de papéis, obrigando, muitas vezes, a editora a recorrer ao mercado negro, pagando preços inflacionados. $O$ índice de inflação era galopante, e a verba que deveria ser suficiente para o ano todo de publicação das revistas esgotava-se logo na primeira tiragem. Antes e durante a guerra, a censura era rígida. Nesse período, as revistas eram obrigadas a cessar as publicações devido à pressão governamental, sendo reativadas no final de ' 45 e no começo de '46. Nesse intervalo, surgiram inúmeras revistas, embora somente algumas tivessem conseguido sobreviver após duas ou três edições.

A publicação das referidas revistas ficava a cargo de um grupo particular de escritores, a fim de alimentar os próprios ideais. No entanto, algumas delas visavam apenas fins lucrativos. A primeira revista literária, intitulada Shinsei (Vida Nova), que iniciou a sua tiragem em novembro de 1945, publicava obras de escritores consagrados, como Nagai Kafû e Tanizaki Jun'ichirô, que haviam permanecido em silêncio durante os anos da guerra. A revista Shinsei foi um fenômeno de vendagem. O sucesso de vendas foi como um termômetro que indicava o quanto o leitor japonês estava ávido por obras literárias de qualidade. Muitos escritores consagrados do pré-guerra que estavam no anonimato agora estavam reativando as suas 
atividades literárias ${ }^{2}$. O primeiro volume do livro de Tanizaki, As Irmãs Makioka, impresso particularmente durante a guerra, foi colocado no mercado em 1946 e logo se tornou um best seller. Os romancistas mais famosos do pós-guerra eram Dazai Osamu, Tanizaki Jun'ichiro, Nagai Kafû, Shiga Naoya e outras dezenas também conhecidos do pré-guerra.

Como Nakamura Mitsuo enfatiza, o período denominado "pós-guerra" não foi exatamente estabelecido. Ele prefere utilizar o termo "literatura de ocupação", designado para as publicações de trabalhos no período compreendido entre 15 de agosto de 1945 a abril de 1952, quando o tratado de paz entre Japão e Estados Unidos entrou em vigor. Outros críticos insistiram, dizendo que "literatura pósguerra" era um termo apropriado, embora tivesse acabado em 1950, com a eclosão da Guerra da Coréia.

Ignorando a opinião dos críticos em relação à literatura de ocupação ou literatura do pós-guerra, os escritores não se referiam ao mais popular, nem aos melhores livros publicados pós '45, mas àqueles livros que tipificavam o período pósguerra. As atenções estavam enfocadas nos escritores que eram filiados aos mesmos pensamentos e idéias, e muitos deles eram de esquerda em suas conviç̧ões políticas, embora não necessariamente em seus trabalhos. Esses romancistas recorriam a métodos melancólicos e atormentados em suas descrições literárias, a fim de expressar os seus sentimentos vivenciados na sociedade decorrente do caos da guerra. Provavelmente, para os leitores não era agradável ler trabalhos tão obscuros que se identificavam com a vida real. Os romances do pós-guerra raramente tornavam-se favoritos do público, mas a obra Pôr-do-Sol, de Dazai Osamu, foi uma exceção.

Quando a guerra finalmente chegou ao seu final, com a declaração do Imperador, a Literatura Japonesa passava por um momento crucial, desde o começo da era Meiji. É verdade que os três livros de Dazai, todos escritos durante a guerra, tinham sido publicados no final de '45. Um desses livros foi Sekibetsu (O Pesar da Separação), editado em cooperação com a Associação Patriótica Japonesa, cujo

\footnotetext{
${ }^{2}$ Nakamura Shin'ichirô declarou que o "mais brilhante exemplo" na literatura pós-guerra tinha sido a volta de Nagai Kafû. (KATO, NAKAMURA, FUNAGAWA, 1964, p. 184)
} 
lançamento coincidiu com a chegada das tropas de ocupação. O patrocínio de tal organização ao livro de Dazai fez com que os americanos entendessem isso como uma afronta à dominação. Com a liberdade de imprensa do pós-guerra, os jornais publicavam ousadamente informações até então consideradas sigilosas pelo governo japonês. Uma dessas informações era o número de mortes de japoneses durante o conflito. Não havia mudanças na política japonesa, mas o militarismo tinha caído em descrédito.

Segundo Donald Keene (1998, p. 968), Takami Jun, autor de Haisen Nikki (Diário da Derrota), escreveu em seu diário informações importantes sobre a reação dos intelectuais japoneses às mudanças do pós-guerra. Ele, Takami, ao se defrontar com o primeiro soldado americano, em oito de setembro de 45 , referiu-se a ele como sendo um "cara imprevidente" e "malicioso". A imposição da censura por parte das tropas de ocupação se deveu ao temor ao ressurgimento do militarismo japonês. O povo ainda carregava o senso de feudalismo e patriotismo. Mas essa censura não era nada se comparada com a do tempo de guerra ou mesmo antes dela. Não havia dúvidas de que isso irritava os jornalistas, que eram obrigados a adequar os seus artigos à nova norma para atender ao código jornalístico. Os autores e editores estavam imunes a essa ameaça, pois os trabalhos literários rejeitados por um censor poderiam ser aprovados, na íntegra, alguns meses mais tarde, por outro censor. A mudança imposta pela política de ocupação acabou trazendo esse tipo de benefício.

Para muitos japoneses do mundo literário, a derrota significou "alforria" para a expressão. Kawakami Hajime (1879-1946) ressaltou que os americanos e ingleses tinham conseguido outorgar a liberdade de imprensa num curto período, coisa que os japoneses não conseguiram em dez anos. Outro feito foi a abolição da polícia especial (tokkô), cuja função era a de espionar pessoas tidas como suspeitas, bem como a revogação da Lei da Preservação da Paz e a promulgação da liberdade de imprensa. A partir de então, qualquer artigo que não fosse barrado pelo Código de Imprensa podia ser publicado. Assim, as informações jornalísticas dadas aos japoneses ficaram mais acessíveis, abrindo a possibilidade de tratar de temas até então considerados tabus, mudando radicalmente a atmosfera do mundo literário. 
Segundo Donald Keene (1998), Takami Jun anotou em seu diário de 29 de agosto de 1945:

[...] sinto que o discurso, publicações, reuniões, associações e todo o resto tornaram-se livre. É como se tivessem tirado um peso dos meus ombros. Tenho agora a consciência de que estávamos mergulhados na Idade Média, vivendo a política daquela era de escuridão e de terror - mas eu não acho que a verdadeira liberdade possa ser outorgada. O Japão terá de crescer muito mais [...]. (KEENE, 1998, p. 1021, tradução nossa)

A ocupação japonesa pelos estrangeiros irritou Takami. Ele se sentiu envergonhado pela obtenção da liberdade não concedida pelo seu próprio governo, mas através de um poder de ocupação. E é esse sentimento que ele descreve em seu diário de guerra. Já segundo o crítico Kawakami Tetsutarô, essa liberdade, independente de sua fonte, foi aceita com alegria e gratidão, especialmente no mundo literário. A liberdade de imprensa significou, por exemplo, que os trabalhos da literatura clássica estavam finalmente "liberados". Obras como Narrativas de Genji (Genji Monogatari), que não podiam ser publicadas livremente durante a guerra, agora estavam liberadas. A tradução da obra em língua moderna feita por Tanizaki Jun'ichirô tinha sido censurada, por tocar em questões referentes à família imperial. Os trabalhos de Saikaku que tiveram expressões ou trechos considerados ofensivos à moral e que foram "tarjados" agora podiam ser impressos na íntegra. Mesmo cenas que retratassem a relação física entre homem e mulher não eram censuradas. Críticos comentavam que a liberdade que os escritores agora gozavam era similar à liberdade dos chônin do período Edo. Houve de certa forma, um clima de entusiasmo pelo renascimento da Literatura Japonesa pós-guerra.

A criação de novas revistas, todas ansiosas por matérias, elevou alguns autores ao status de escritores literários. O crítico Nakamura Mitsuo escreveu que na pré-guerra os escritores japoneses eram tratados pela sociedade como sendo escravos fugitivos ou foras-da-lei, mas após a guerra, muitos deles foram elevados à categoria estelar de galã de cinema. Muitos pais que antes proibiam seus filhos de se tornarem escritores agora os incentivavam. Mas como lembra Nakamura, a mudança de status tinha o seu lado negativo. Iniciou-se a comercialização da literatura, a 
proliferação do que foi chamado de chûkan shôsetsu (ficção mediana), que atendia os leitores com trabalhos comerciais, sem privilegiar a estética literária.

A crítica feita por Nakamura sobre a literatura pós-guerra foi contestada pelos críticos progressistas, especialmente aqueles ligados à revista Kindai Bungaku (Literatura Moderna), que tiveram papel fundamental na criação da nova Literatura Japonesa. A crítica de Nakamura teve um efeito devastador por ter vindo de alguém tão influente como ele. O tempo mostrou, no entanto, que os trabalhos da Kindai Bungaku eram sérios e em momento algum foram armas para a comercialização da literatura ${ }^{3}$.

A revista Kindai Bungaku foi fundada em 1946, alguns meses após o fim da Segunda Grande Guerra. Seus sete fundadores eram marxistas ou comunistas que estavam decididos, principalmente, a não permitir que a revista caísse no dogmatismo do movimento literário proletário. O editor Honda Shûgo fez a lista dos princípios básicos a serem observados pela revista na admissão dos membros (dônin):

1. Crença no princípio da "arte pela arte" e espírito de nobreza.

2. Persistência na perspectiva histórica.

3. Respeito pelo ser humano.

4. Garantia de liberdade provinda de facções e partidos políticos.

5. A busca pela verdade literária, independente de facção ou ideologia.

6. Rejeição ao utilitarismo na literatura.

7. Olhar voltado para o futuro, sem estar atado às tendências atuais.

8. A missão deve ser executada pela geração atual (faixa etária por volta dos 30 anos).

O propósito expresso de evitar o compromisso político não era uma mera promessa, embora em seu primeiro número o entrevistado tenha sido o crítico marxista Kuhara Korehito, um dos raros literatos que tinha sido preso. No segundo número, o entrevistado foi Kobayashi Hideo. Ele era um crítico bastante admirado

\footnotetext{
${ }^{3}$ A maioria dos críticos tinha enfatizado a importância da Kindai Bungaku no desenvolvimento da literatura do pós-guerra. Miyoshi Yukio, em Nihon Kindai Bungaku Daijiten, p. 77, comparou sua importância à das revistas literárias Bungakkai da era Meiji e Shirakaba da era Taishô.
} 
pela sua recusa em aceitar a introdução de idéias políticas em seus trabalhos. Em pouco tempo, os membros da revista passaram de cinco para sete. Dentre os novos membros estava Odagiri Hideo, de 29 anos. Dos sete membros, somente Haniya Yutaka era escritor de ficção. Ele publicou em série o seu romance Shirei (Fantasma), que se tornaria o trabalho mais importante de Kindai Bungaku (Literatura Moderna). Os capítulos subseqüentes foram publicados entre '46 e '49. 0 romance Shirei foi considerado o único Shisô Shôsetu (Romance de Idéias) escrito no Japão. Haniya era anarquista e, mais tarde, membro do partido comunista. Foi preso em 1932 por violação às Leis da Preservação da Paz. Em 1933, converteu-se, e em 1938, foi solto em conseqüência da saúde debilitada. Após a soltura, Haniya fundou a revista literária Kôsô juntamente com Hirano Ken, Sasaki Kiichi, entre outros. O romance Shirei foi escrito e reescrito por longos anos, e é considerado um dos romances de mais difícil compreensão da Moderna Literatura Japonesa.

A revista rival, Shin Nihon Bungaku, criada alguns meses depois da Kindai Bungaku, teve uma vida mais longa devido ao apoio recebido do Partido Comunista japonês. O objetivo da revista era a criação de uma minshu shugi bungaku (literatura democrática), conceito que foi além da literatura proletária. Essa literatura destacava-se por ter entre seus membros escritores do proletariado e simpatizantes pertencentes a outras classes. A inauguração da Shin Nihon Bungaku (Associação da Nova Literatura Japonesa) contou com a presença proeminente de não-comunistas, como Shiga Naoya, Masamune Hakuchô e Uno Kôji. Todos eles estavam cadastrados como membros de apoio devido às contribuições do passado para o desenvolvimento democrático da Literatura Japonesa. A democracia foi definida como uma conduta do Partido Comunista. Por um tempo, a Associação da Nova Literatura Japonesa tentou, como o velho movimento literário proletário, encorajar a literatura operária, mas as contribuições advindas de fábricas eram irrisórias. Portanto, a Shin Nihon Bungaku começou a captar artigos somente de escritores profissionais e de intelectuais. Em 1950, seus líderes foram denunciados pelos próprios companheiros. Nesse mesmo ano, com a divisão dentro do próprio partido, houve a criação da revista literária marxista denominada Jinmin Bungaku (Literatura do Povo), cuja literatura era 
unicamente feita pelo proletariado. Essa disputa de poderes não trouxe nenhum resultado positivo para os leitores.

A experiência da derrota do Japão refletiu direta ou indiretamente nos trabalhos de alguns escritores. A nítida simbolização desse período está nos romances de Dazai Osamu Pôr-do-Sole Desqualificado Como Ser Humano, de 1948. Dazai começou sua carreira literária muito jovem e depois se juntou à escola romântica japonesa na década de 1930 . Ao término do seu colégio e ingresso na universidade, tomou parte em atividades ilegais do Partido Comunista, que estava em plena atividade naquela época. Depois de dois anos, em 1932, ele se desligou do partido por pressões governamentais. Dazai escreveu Pôr-do-Sol justamente na época em que o Sol do Império Japonês estava se pondo, e Desqualificado Como Ser Humano quando o Japão se encontrava inabilitado para ser uma nação independente.

\section{Dazai Osamu e a Burai-ha (Corrente dos Decadentes)}

Dazai Osamu é considerado um dos representantes do Burai-ha (Corrente dos Decadentes), apesar de sua forte tendência ao Shishôsetsu (Romance do Eu). Logo após o término da Segunda Guerra, alguns escritores com renomada reputação adquirida na pré-guerra começaram a publicar trabalhos de ficção, com a adesão de escritores do pós-guerra que produziam obras com uma identidade própria. Dentre eles destacam-se, além de Dazai Osamu, Sakaguchi Ango, Oda Sakunosuke e Ishikawa Jun. O grupo mereceu atenção de críticos como Itô Sei.

Inicialmente, o grupo era conhecido como gesaku ${ }^{4}$ ou neo-gesaku, provavelmente por apresentarem características semelhantes aos escritores do período Tokugawa que introduziam críticas à sociedade de uma maneira

\footnotetext{
${ }^{4}$ Gesaku prosa de ficção composta entre 1770 a 1870 significava literalmente composição cômica.
} 
deliberadamente cômica, até mesmo burlesca. O escárnio dos escritores neo-gesaku implicou rejeição por parte dos auto-satisfeitos escritores do grupo Shirakaba.

Os escritores neo-gesaku vinham de famílias abastadas, embora fossem associados à classe mais inferior, e eram notórios em beber demasiadamente, muitas vezes mostrando comportamentos desordeiros. Embora muitos deles fossem atraídos pelo Comunismo, alguns se desiludiram com a teoria marxista e com as atividades diárias de membros do partido. Uma implícita rejeição ao presente por parte dos escritores neo-gesaku freqüentemente levava-os a manifestar um grande interesse pelo passado, especificamente o passado relacionado aos escritores gesaku da era Edo.

O desespero existencial dos romancistas não era reconhecido pela sociedade e muitos deles, inclusive Dazai, cometeram suicídio ou sucumbiram. A compleição da combinação de uma depressão intensa normalmente produzida pela perda de esperança e repulsa aos valores estabelecidos pela sociedade foi expressa por eles como uma grande indignação e farsa.

O termo Burai tem sua origem na China. Na ocasião da cerimônia de conclusão do palácio Wei Yang, do Imperador Han Kao-Tsu, este relatou que, quando jovem, tinha sido um Burai, ou seja, tinha sido incapaz de conduzir os negócios familiares e tinha-se mostrado menos cauteloso em relação a seus irmãos. Muito antes de o grupo ser chamado de Buraiha, Dazai adaptou o termo francês libertins, utilizado especialmente por Francois Villon, cuja vida libertina alimentou-o com ricos materiais para a composição literária. A vida desregrada dos membros do Buraiha e a sua falta de uma política filosófica sustentável contribuíram para o débil interesse mostrado pelos críticos literários de pós-guerra.

Destacam-se como características dos escritores Buraiha a falta de objetivo e a tendência a se embebedar enquanto podiam estar escrevendo. Outro atributo essencial ao termo acima seria o espírito de rebeldia contra a sociedade e sua criação literária.

Dazai Osamu pode ter sido o primeiro a utilizar o termo Buraiha numa carta enviada em resposta a Kishi Yamaji (1899-1973), em maio de 1946. Kishi era um ex- 
proletário que se tornara escritor. Ele fora forçado a interromper a carreira literária temporariamente, em obediência ao período de silêncio imposto pela guerra, retomando a atividade após a guerra. A resposta de Dazai a Kishi seria para dar esclarecimento sobre as críticas que o último havia feito sobre o seu livro Sekibetsu (Pesar da Separação).

Dazai, durante o período da guerra, ciente da nova e deplorável tendência do jornalismo japonês, em protesto, chegou a não ler jornais e revistas. Segundo Keene (1998, p. 1024), as mentiras jornalísticas desse período haviam chegado à tona, o que o levou a declarar: "Um país que esquece o seu senso de vergonha não é um país civilizado. O que você diria da União Soviética hoje? O que você acha do Partido Comunista japonês?". Apesar de apoiar a guerra, ele rejeitava as "regras do jogo" e por isso, alguns de seus trabalhos haviam sido proibidos pelos militares, e novos manuscritos foram reduzidos à míngua.

Dazai foi mais longe ao dizer, conforme traz Keene (1998):

Eu gostaria de saber se o romance ideológico vai ser popular novamente. Não será aterrador como um romance da direita que era publicado durante a guerra, mas ele será capaz de irritar. Eu sou 'libertin', eu rejeito a repressão. Eu zombo das pessoas que compartilham um olhar prazeroso entre si. Por isso, estou predestinado a nunca ter sucesso, não importa quanto tempo eu espere. (apud KEENE, 1998, p. 1024, tradução nossa)

Dazai associou os caracteres chineses Buraiha à pronúncia Libertin. Logo após a guerra, em 1945, escreveu o livro $A$ Caixa de Pandora, onde faz referência ao Libertins, tema utilizado como prova de liberdade dos pensamentos e de menosprezo às convenções sociais. No livro, ele faz referência à obra de Cyrano de Bergerac, como um exemplo francês de um membro do Buraiha.

Um rebelde que vai contra as convenções e a moralidade imposta por militares tende a ser mais popular entre os jovens. Os Buraiha têm sido populares especialmente entre aqueles que se recusam a admitir a sabedoria do passado. Sakaguchi Ango, cujo trabalho é escrito em forma de ensaio, enaltece a decadência e recorre ao público jovem. Oda Sakunosuke, um escritor menos conhecido, é mais lembrado pela sua breve e caótica vida do que pelos seus trabalhos. Embora não 
tenha muitos trabalhos, ele narra a vida do povo de classes mais baixas de Osaka. Ishikawa Jun foi um importante escritor Buraiha que teve uma vida longa, diferentemente dos outros membros. Em suas obras existe humor, especialmente naqueles trabalhos escritos no período pós-guerra.

\section{Dazai Osamu e o Romance do Eu}

A influência marcante no estilo de Dazai e no Romance do Eu japonês remonta ao passado da Literatura Japonesa. Para compreender seu estilo e sua obra temos de compreender o movimento naturalista, que ocorreu no Japão entre 1906 e 1910 e teve desdobramentos nos anos posteriores até o Romance do Eu. O Naturalismo exerceu influência direta nas tradições que dominaram a literatura moderna da época, mas alguns autores, como Natsume Sôseki, Mori Ôgai, Nagai Kafu, Tanizaki Jun'ichirô e Kawabata Yasunari, ou eram indiferentes ou ativamente contrários ao Naturalismo.

Segundo afirma Donald Keene (1998),

[...] o Naturalismo japonês desenvolveu-se paralelamente numa linha bastante diferente de qualquer exemplo europeu. O Naturalismo europeu surgiu, em grande parte, como reação ao excessivo individualismo da literatura romântica, mas no Japão, a característica mais marcante da escrita naturalista era a procura pelo indivíduo. Essa procura foi intensificada depois que o breve florescer de uma literatura especificamente romântica tinha passado, e alcançou máxima expressão no Romance do Eu, que era uma forma de estabelecer a individualidade dos autores. O Naturalismo de Zola ou Maupassant não chegou a ser interpretado como um método de examinar os seres humanos com caracterização científica, mas como uma reprodução absolutamente fiel de reais eventos, sem admissão de ficção ou até mesmo de imaginação. (KEENE, 1998, p. 221, tradução nossa)

Como pode ser observado, no Naturalismo japonês, normalmente estava retratada a vida dos próprios escritores e suas angústias individuais. Esses escritores eram impiedosamente sinceros, nem mesmo acrescentavam elementos fictícios para 
evitar que a família passasse pelo constrangimento de estar sendo exposta em seus escritos. Com a adoção do Naturalismo, os adeptos do Watakushi Shôsetsu (Romance do Eu), que estabelecia a individualidade na Literatura Japonesa, beneficiaram-se dessa nova técnica literária. Até os escritores que eram contrários ao Naturalismo, por ser uma tendência estrangeira, como Natsume Sôseki, Mori Ôgai, entre outros, também aderiram a essa nova corrente (Romance do Eu).

O Naturalismo japonês estava principalmente associado ao Naturalismo de Emile Zola, que usou o termo em defesa de um estudo científico da sociedade humana na literatura. Seus romances dedicaram atenção particular aos efeitos da hereditariedade e do ambiente na formação do caráter que eram, geralmente, tirados dos extratos de poder da sociedade. Ao referir-se aos romances de Zola, Donald Keene (1998) afirma que:

[...] Os romances naturalistas de Zola e de seus seguidores foram caracterizados como 'cheios de brutalidade, feiúra e degradação'. Um romance sobre o cortiço que mostre esposas espancadas, embriaguês e a promiscuidade sexual é, normalmente, naturalista [...] (KEENE, 1998, p. 221, tradução nossa)

Mori Ôgai (1862-1922) reprovava Zola por escolher a verdade em lugar da beleza e a crítica em lugar da técnica. Ele foi mais longe ao definir os personagens de Zola como sendo uma coleção de loucos, bêbados e idiotas. A crítica feita por Ôgai a Zola estava baseada em fontes que ele havia lido em retraduções, ou que ele havia lido dentro do resumo das obras daquele autor. Muitas vezes, o sentido lato da palavra era distorcido devido aos romances principais de Zola serem longos e apresentarem problemas na tradução. Poucos japoneses eram capazes de ler em francês, e as traduções inglesas de Zola eram difíceis para a maioria dos leitores, E, ao passar pela mão de tradutores, acontecia de a palavra original ser deturpada. A primeira apresentação sistemática do Naturalismo para o japonês foi feita por Ôgai em um artigo publicado em 1889, desaprovando uma aproximação da medicina experimental de Claude Bernard com os romances de Zola.

Os trabalhos de Zola foram bem recebidos por alguns escritores, como Uchida Roan, conforme afirma Keene (1998): 
Ele foi o primeiro escritor a traduzir e escrever de forma apreciável sobre Zola. Uchida exaltou Zola por ter estudado o tipo humano cientificamente e por ter descrito os seres humanos e a natureza sem moral ou preconceitos religiosos. (KEENE, 1998, p. 224)

Por outro lado, obras de Guy de Maupassant, geralmente através de traduções indiretas do inglês, eram bastante conhecidas, havendo muitas adaptações dos seus trabalhos. De acordo com Keene (1998):

\begin{abstract}
A imitação não somente de seus temas eram freqüentes, mas das suas técnicas, que contribuíram diretamente para a criação de uma nova literatura japonesa. Até mesmo os escritores totalmente desinteressados no Naturalismo foram atraídos por Maupassant. (KEENE, 1998, p. 224, tradução nossa)
\end{abstract}

Tamanha era a aceitação de Maupassant por parte dos leitores japoneses que eles começaram a basear-se nas traduções inglesas para poder lê-lo, devido à escassez de leitores capazes de ler o original em francês. Para facilitar a leitura e assimilação de Maupassant foi adquirida pelo escritor Ueda Bin, em 1896, uma coleção completa de traduções inglesas de histórias de Maupassant intitulada 0 Número Estranho. Os exemplares passaram das mãos de Ueda para as de Yanagita Kunio, Tayama Katai, Kunikida Doppo e, por fim, Masamune Hakuchô. Além desses autores, os exemplares foram entregues a outras figuras importantes envolvidas no movimento naturalista.

Pelo que pôde ser observado e pelo interesse despertado nos escritores japoneses por Maupassant, indubitavelmente as suas obras foram influenciadas pelo Naturalismo francês. A atração desses jovens escritores por Maupassant reside na sua maneira não emotiva e imparcial de descrever as tragédias ordinárias das vidas diárias. Esse seria o assunto da maior parte da ficção naturalista japonesa.

Para Kobayashi Hideo (1902-1983), um dos mais influentes críticos literários da Moderna Literatura Japonesa, os escritores japoneses de Naturalismo tinham em mente que os conceitos provenientes dos escritores franceses naturalistas eram muito difíceis de serem digeridos e de difícil compreensão. E que os japoneses ainda não estavam preparados para conviver com conceitos ocidentais, porque a Literatura 
Japonesa possuía uma antiga e poderosa tradição. Conscientemente ou não, esses escritores naturalistas japoneses conviviam com uma técnica milenar, por essa razão, não queriam se apoiar em conceitos ocidentais infundados para impulsionar as suas carreiras. Portanto, eles (naturalistas japoneses) possuíam um senso perfeito de uma estética literária própria. Para esses mesmos escritores, não havia meio mais natural e agradável de escrever do que diluir um conceito importado recentemente e fazer a fusão de técnicas literárias nativas. Os naturalistas japoneses estavam posicionados para desempenhar esse experimento de fusão de conceitos ocidental e oriental. Esse posicionamento desses naturalistas estava, seguramente, mirando os conceitos e a prática literária, e estes não estavam interessados nas vidas reais dos autores.

Os romancistas japoneses importaram as técnicas de romancistas naturalistas europeus sem entender as forças sociais que os tinham conduzido para as suas criações. Para Kobayashi Hideo, no Japão, todos os romancistas modernos haviam começado como naturalistas, com a rara exceção de Mori Ôgai e Natsume Sôseki.

Kobayashi Hideo (1902-1983), referindo-se ao Romance do Eu europeu, cita uma das passagens da obra de Jean Jacques Rousseau intitulada Confissões, onde ele declara que não estava se expondo diante da sociedade e não estava preocupado em descrever a sua vida privada. Ao contrário, ele queria questionar a posição e o significado do indivíduo na sociedade. $\mathrm{O}$ argumento de Kobayashi foi que o recente movimento europeu Romance Confessional era exemplificado nos trabalhos de André Gide, Marcel Proust e James Joyce que apareceram depois do Naturalismo europeu (representado por Emile Zola e seus seguidores). O Romance do Eu japonês foi espelhado no Romance Confessional europeu e estabeleu-se como uma corrente opressiva. Escritores como Gide tentaram restabelecer a humanidade (ningensel) que havia desmoronado sob a impressionante pressão ideológica do Naturalismo e do Positivismo do século XIX.

Na segunda metade da época Taishô aconteceram diversos fatos importantes no Bundan (Mundo Literário) que delinearam a trilha de "fugitivos sociais" para a 
autodestruição (hametsugata) ${ }^{5}$. A primeira trilha pode ser vista como resultado direto do princípio de unidade entre a vida do escritor e sua obra, que era o ponto máximo no Bundan. Os escritores sentiram a necessidade de transformar as suas vidas em material adaptável literário que se encaixasse em termos do Romance do Eu, e assim satisfazer as expectativas dos leitores, com destaque ao lado sombrio da vida humana.

Entre o final do período Taishô e 1935, dois eventos marcaram o debate sobre o Romance do Eu:

1. A introdução e domínio intelectual do marxismo, que forçaram os intelectuais japoneses a refletir criticamente e reconsiderar a noção do auto-individualismo que se configurava atrás da democracia Taishô.

2. A importação e tradução de romances autobiográficos contemporâneos de André Gide, Marcel Proust e James Joyce. No final do período Taishô, especialmente de 1926 até o começo de 1930, o marxismo atraiu um grande número de intelectuais e escritores literários como Dazai Osamu. Contudo, o movimento comunista foi prontamente reprimido pelo governo dos anos '20, e alguns marxistas denominados "escritores proletários" abandonaram o comunismo. Eles seguiram os seus líderes do partido como uma renúncia pública ao "comunismo estrangeiro", em 1933. O fato é que esses ex-escritores proletários começaram a escrever romances confessionais sobre sua renúncia ao comunismo, deixando os leitores cientes da persistência da tradição do Romance do Eu.

Ao mesmo tempo em que Dazai utilizava-se de procedimentos do Romance do Eu, estava também próximo à literatura proletária, simpatizante que era da revolução marxista. A corrente proletária surgiu no final da era Taishô (1912-1926) e no começo da era Shôwa (1926-1989). Sua visão pessimista da vida fê-lo incapaz de corresponder à visão idealista marxista da sociedade, e a sua atividade de esquerda

\footnotetext{
${ }^{5} \mathrm{O}$ termo Hametsugata foi utilizado por Itô Sei para descrever escritores do Shishôsetsu (Romance do Eu), cuja atitude básica de fuga havia transformado gradualmente suas vidas em autoaniquilamento, culminando na morte.
} 
teve duração curta. Além do mais, a disciplina rígida de um movimento ilegal, em combinação com as pressões exercidas pela polícia, fez com que Dazai abandonasse as participações ativas no movimento marxista.

O movimento literário proletário era brutalmente reprimido, e os escritores proletários eram obrigados a se converter (tenkô). Com poucas exceções, os convertidos se afundavam no desespero niilístico e apatia, ou mudavam as suas devoções para a política de ideologia imperialista.

De acordo com Itô Sei, as obras do Romance do Eu pertencia aos não privilegiados. No conteúdo de um Romance do Eu havia a privação do amor de mãe, a traição da esposa, a pobreza, a saúde debilitada, a rejeição por todos, o fracasso social e o abandono. Escritores como Kasai Zenzô, Kamura Isota e Dazai Osamu esforçaram-se para retratar esses aspectos através da realidade de suas vidas, que era testemunhada por amigos e familiares. O Romance do Eu exigia do autor um constante enfoque de crises ou dramas existenciais em sua vida pessoal.

O Romance do Eu autodestrutivo reflete a atmosfera de decadência e degeneração e utiliza-se do auto-escárnio, como a obra Kokyô Wasurerubeki (Esquecer a Terra Natal, 1936), de Takami Jun, ou Dôke no Hana (Flores de Palhaço, 1935), de Dazai Osamu. Esta obra, embora um típico exemplo autodestrutivo de natureza histriônica, é um produto fracassado do movimento proletário. Hirano Ken (1975) sugere que a atitude histriônica de autodestruição que caracterizou a vida e obra de Dazai se devia, em parte, ao seu profundo sentimento de fracasso pessoal no movimento revolucionário. Algumas de suas obras, como Dôke no Hana, podiam ser lidas como uma variante da Literatura Tenkô ("de conversão").

Dazai é considerado a última vítima mais notável do "método de Romance do Eu". Ao longo de sua vida, Dazai parece ter ido além dessa categoria da fuga social. Dá a nítida impressão de ter direcionado a sua vida para a autodestruição. Esta constatação está patente na sua relação familiar rompida, uma vida de libertinagem em Tóquio, insegurança financeira e psicológica, saúde arruinada, drogas, débitos e diversas tentativas de suicídio fracassadas. 
As obras de Dazai são ficcionais com alguns aspectos naturalistas, mas escritas com o espírito do Romance do Eu. Isso significa que os fatos descritos em seus romances não aconteceram necessariamente na sua vida, mas acompanham fatos da realidade da vida de pessoas do seu convívio através de relatos do cotidiano, diários, etc. Os sentimentos da época inseridos na sua obra eram aceitos pelos críticos e leitores como sendo do Romance do Eu.

No final da Segunda Guerra Mundial, os escritores do Romance do Eu, como Kasai Zenzô e Kamura Izota estavam mortos. Em 1948, Dazai cometeu suicídio. Anos mais tarde, seu discípulo e amigo, Tanaka Hidemitsu, também o fez. Dazai deixou escrito Ningen Shikkaku (Desqualificado como Ser Humano), logo reconhecido como um Romance do Eu "autodestrutivo". A morte desses importantes escritores levou críticos, como Hirano Ken (1907-1978), a refletirem sobre a vida dos romancistas, bem como sobre a relação existente com suas obras. Hirano fez a seguinte observação: "Eu tento dar uma visão panorâmica dos trabalhos de um autor em particular a fim de aprender como ele viveu a sua vida".

A nova era de pós-guerra, de riqueza e liberdade política, trouxe a mentalidade de tôbô dorei (escravos fugitivos), que deu uma redefinição dos valores literários e do papel dos homens literários na sociedade. Mas o suicídio de Dazai, bem como dos demais romancistas, marca o início do fim de uma época na tradição da Moderna Literatura Japonesa. 


\section{Capítulo II}

\section{Dazai Osamu: vida e obra}

Neves de Tsugaru

Neve fina neve dura

Neve granulosa neve áspera

Neve macia neve congelada

Neve aquosa. (Dazai Osamu)

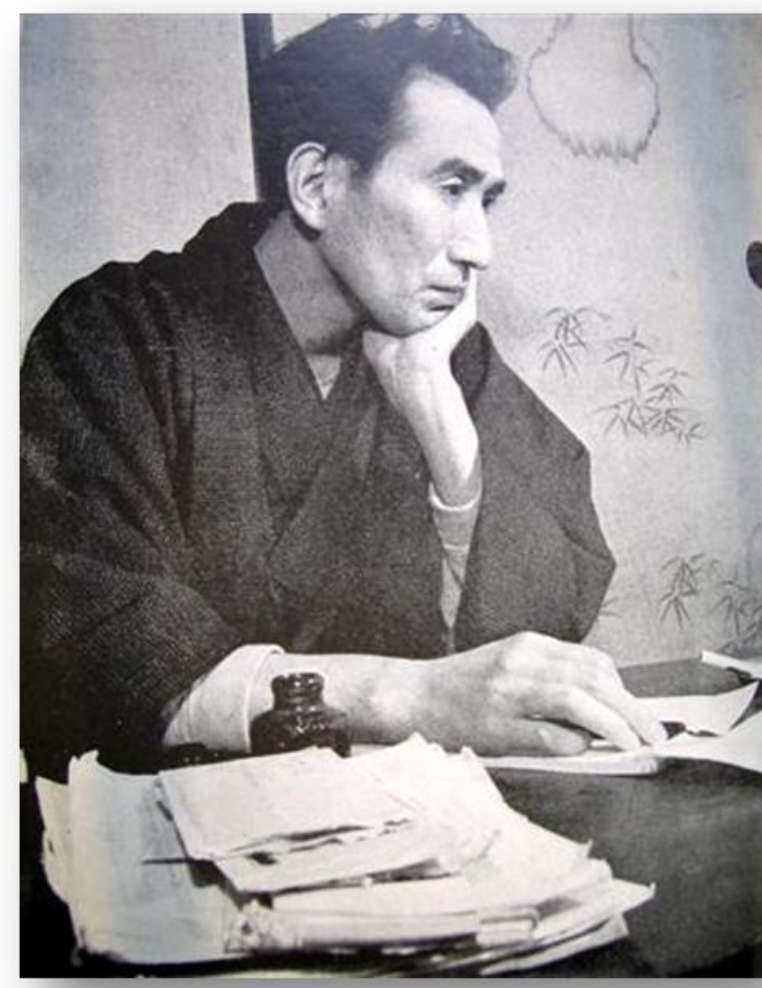

Figura 01 - Dazai: vida e obra. ${ }^{6}$

Fonte: SHINCHÔ, 1969, p. 2

\footnotetext{
${ }^{6}$ Dazai após ter escrito Shayô (Pôr-do-Sol), em 1947.
} 


\section{Infância e Adolescência}

Dazai Osamu, romancista e escritor de ficção e contos, cujo nome verdadeiro era Tsushima Shûji. Nasceu em 19 de junho de 1909, em Kanagi, perto da planície de Tsugaru, no extremo norte do Japão, na província de Aomori. Era o décimo filho, entre onze, de Tsushima Gen'emon e de Tane.

No final do século XIX, a família Tsushima era uma das mais poderosas em Tsugaru. O pai, Gen'emon, era membro da Casa dos Nobres. Era um político muito respeitado e influente na região. Dazai sempre se incomodou que seus ancestrais fossem fazendeiros, por isso ele mesmo sempre afirmava que não passava de um camponês ignorante. Dazai pertencia decididamente à classe média alta. Isso significava que numa região de extrema pobreza como Tsugaru, quem era portador de alguma fortuna como a do seu pai era considerado um aristocrata.

Apesar da fortuna da família, Dazai não teve uma infância feliz. Ele se sentia uma criança solitária, deslocada em relação aos outros irmãos, numa imensa casa que sempre estava cheia de gente. Viviam ali mais ou menos 30 pessoas. Dentro desse imenso território, Dazai era uma criatura insignificante, pois a mãe estava sempre doente e ausente para cuidar da sua prole. Dazai foi criado pela sua tia Kie e dividia o quarto com as quatro filhas dela, que Dazai tinha como irmãs.

Em abril de 1912, veio morar na casa dos Tsushima a ama seca chamada Take, na época com 14 anos. Ela era a empregada pessoal de Kie. Take sempre afirmava que Dazai era filho da sua patroa Kie, que tinha um carinho especial pelo garoto. Esse boato confundiu a cabeça do pequeno Dazai. Com isso, ele nunca conseguia discernir corretamente quem seria a sua verdadeira mãe até os seus sete ou oito anos de idade. 


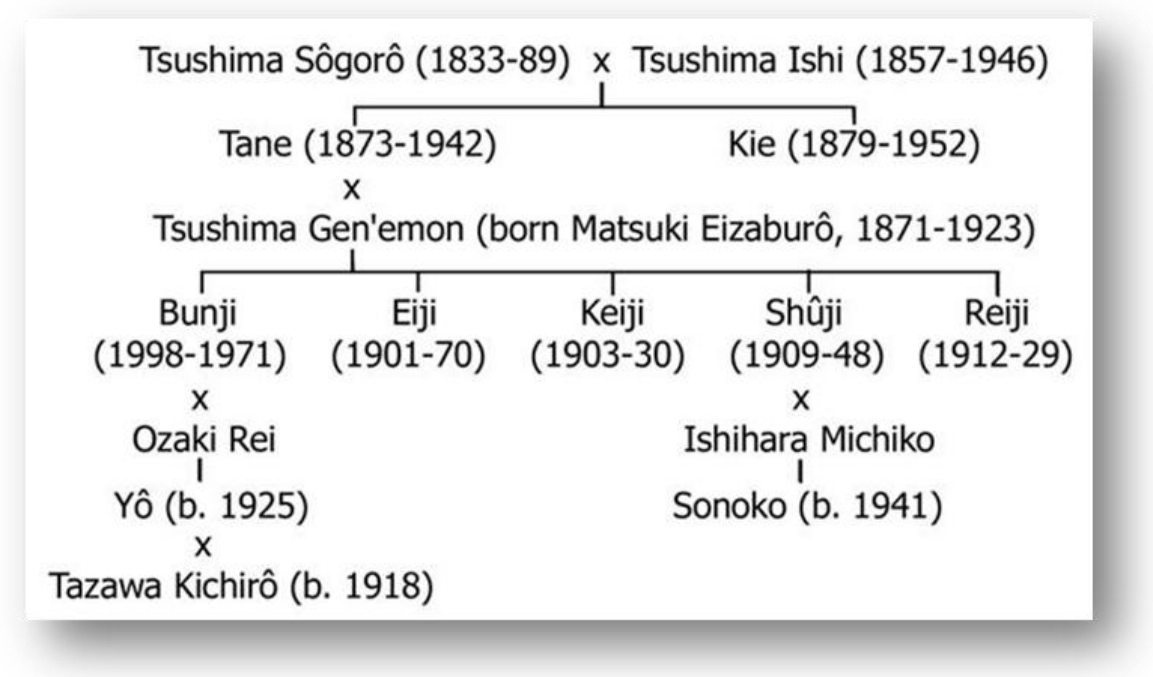

Figura 02 - Árvore genealógica da família Tsushima. Fonte: DAZAI, 1985, p. xvii.

Tsushima Sôgorô (1833-89) casou-se com Tsushima Ishi (1857-1946), e desse casamento nasceram Tane (1873-1942) e Kie (1879-1952). Tane casou-se com Tsushima Gen'emon (nome de nascimento Matsuki Eizaburô, 1871-1923) ${ }^{7}$. Desse enlace nasceram os filhos Bunji (1898-1973), Eiji (1901-1970), Keiji (1903-1930), Shûji (Dazai) (1909-1948) e Reiji (1912-1929) e mais seis irmãs. Pode-se dizer que a história da família Tsushima na metade do século XX é a história de dois irmãos: Bunji (irmão mais velho) e Shûji (Dazai).

Quando o pai, Gen'emon, faleceu em 4 de março de 1923, o filho mais velho, Bunji, sucedeu-o nos negócios familiares, trilhando inclusive o caminho político de seu pai. Em 1925, aos 27 anos, Bunji se elegeu como prefeito de Kanagi, chegando à Assembléia da prefeitura de Aomori até a eclosão da Segunda Guerra Mundial.

Quando a família Tsushima, assim como os outros senhores de terras, perdeu o status de aristocracia em decorrência da reforma agrária durante a ocupação, Bunji recuperou as perdas elegendo-se governador de Aomori. Ele sempre esteve envolvido em atividades políticas até a sua morte. Tendo o irmão dominador e a figura materna quase nula, Dazai nunca se sentiu em casa na família Tsushima. Ele

\footnotetext{
${ }^{7}$ Como na família de Tane e Kie não havia homens para suceder e herdar o nome Tsushima, Gen'emon adotou o sobrenome da mulher. Nessa época, era comum o marido ser adotado pela família da esposa.
} 
via Bunji com respeito, mas não se deixava intimidar pela sua figura autoritária. Bunji se achava o dono da verdade e tinha Dazai como um rebelde, e sempre reprovava as atitudes do irmão.

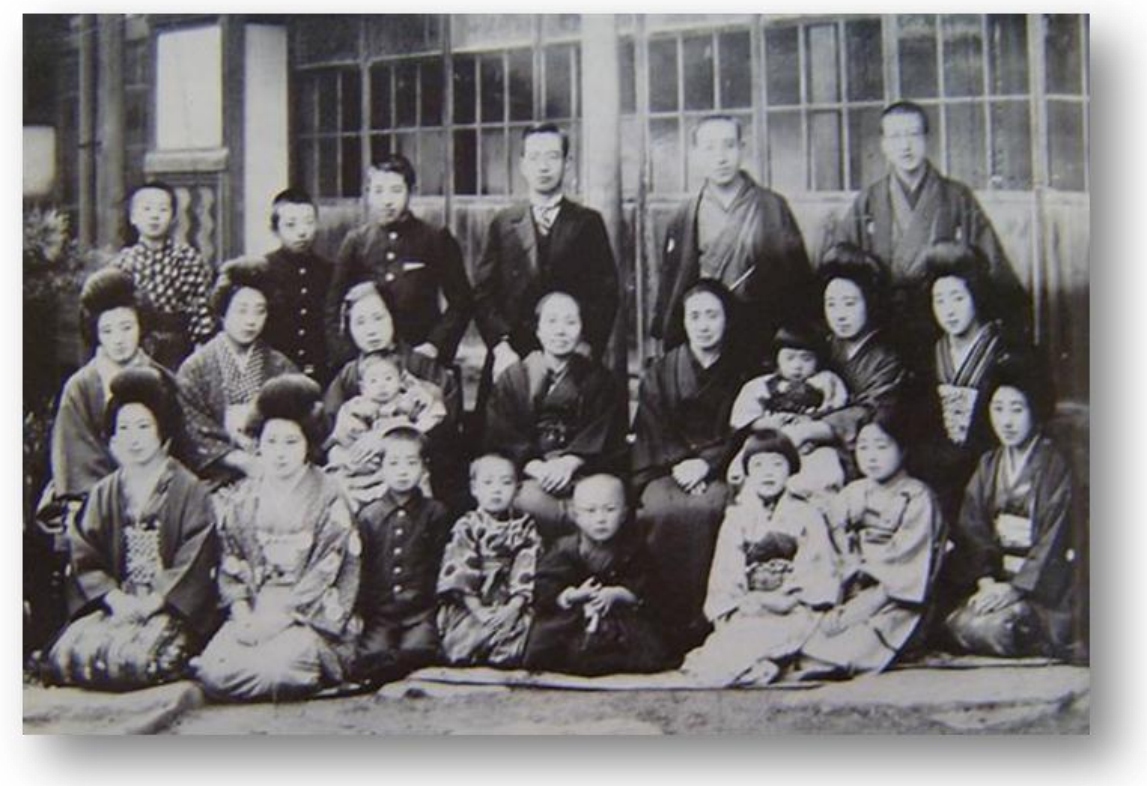

Figura 03 - Foto da Família Tsushima. ${ }^{8}$ Fonte: DAZAI, 1985, p. 98b.

Ao ingressar na escola primária em Kanagi, Dazai sofreu uma mudança drástica em sua vida. Essa mudança permaneceu indelével na sua memória, mesmo na idade adulta: a separação com a pessoa que mais ele amava, Take, sua ama. Ela deixou a família Tsushima para se casar e mudou-se para outra localidade. Também Kie, sua tia, por quem ele tinha grande consideração, mudou-se para outra cidade.

Embora Dazai não comentasse os seus sentimentos de perda com ninguém, freqüentar a escola significava perda, assim como ausência de um ente querido no seu círculo. O pesar da separação foi maior porque as duas mulheres mais importantes da sua vida nem aos menos se despediram do pequeno e inseguro menino. Dazai faz referência a isso no conto Omoide (Lembranças), enfatizando que essa ruptura abrupta levou-o a odiar a escola. Como se não bastasse a perda desses

\footnotetext{
${ }^{8}$ Explicação original da foto: "A casa da família Tsushima, 1925. Fileira traseira, da direita para a esquerda: Shûji [Dazai], Eiji, Bunji, Reiji. Fileira do meio, da direita para a esquerda: Rei, esposa de Bunji, sua irmã Toshi com sua filha Yô, Tane, Ishi, Kie." (DAZAI, 1974, p. 98b, tradução nossa). Fotografia cedida por Tsugaru Shobô.
} 
dois entes queridos, Take e Kie, enquanto cursava o ginásio e o colégio, ele teve que deixar o lar e morar com parentes distantes.

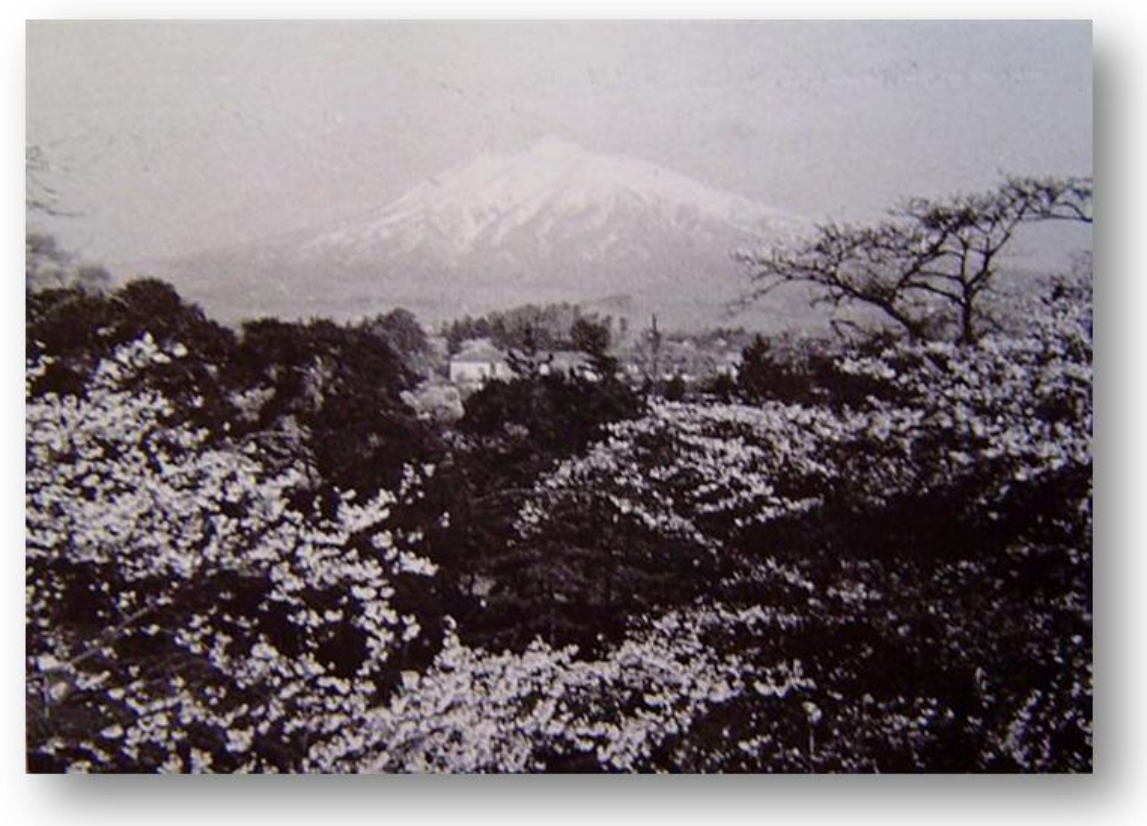

Figura 04 - Monte Iwaki visto do Castelo de Hirosaki ${ }^{9}$ Fonte: DAZAI, 1985, p. 98 I.

Em 1927, Dazai ingressou no colégio da cidade de Hirosaki, hoje Universidade de Hirosaki. Nessa época ele já demonstrava um enorme interesse pela criação literária. Em Kanagi, ele já havia trabalhado na revista literária local e depois, juntamente com amigos, tinha começado um jornal chamado Shinkirô (Miragem). Como sempre, seu irmão Bunji reprovava sua atividade literária, temendo que com isso ele pudesse negligenciar os seus estudos, o que acabou acontecendo quando Dazai começou a se envolver com as atividades políticas de esquerda.

O envolvimento de Dazai com o Comunismo, segundo Sôma Shôichi, tem três fases: a primeira fase é o período no colégio de Hirosaki, no ano de 1928; a segunda fase foi no ano de ingresso na Universidade Imperial de Tóquio, no ano de 1930; a terceira fase foi no ano de 1931.

\footnotetext{
${ }^{9}$ Explicação original da foto: "Monte Iwaki visto do Castelo de Hirosaki. 'Eu estava de pé observando o Monte Iwaki no canto de um espaço aberto em frente do ponto principal, de repente eu notei que silenciosamente a cidade dos sonhos envolvia os meus pés."' (DAZAI, 1985, p. 98I, tradução nossa). Fotografia de Hanada Chiaki.
} 
Em 1930, aos 21 anos, Dazai deixou a provinciana e remota Tsugaru para ir à grande metrópole, Tóquio, centro cultural ativo, um reduto de escritores famosos, centro da atividade política borbulhante. Dazai ingressou na Universidade Imperial de Tóquio, no Departamento de Literatura Francesa, sem nunca ter estudado a referida língua. Segundo James O'Brien (1985), foi nesse período que Dazai teve contato com o pensamento marxista. A origem desse pensamento vinha do modelo europeu, e ele se encantou com esse ideal, atraído pelas ações sociais do marxismo.

Em outubro de 1930, uma jovem chamada Hatsuyo, que Dazai conhecera em Hirosaki, mudou-se também para Tóquio. Dazai anunciou aos seus familiares que se casaria com Hatsuyo. Bunji foi contra e ameaçou retirar o apoio financeiro que lhe dava mensalmente. Em retaliação, Dazai embebedou-se com uma desconhecida garçonete no bar de Ginza e fez um pacto de morte com ela. Os dois se atiraram no rio. Dazai sobreviveu, mas a garota acabou morrendo.

Após esse incidente, decepcionado e desiludido com a vida, Dazai foi se envolvendo cada vez mais com o Partido Comunista. Todo mês dava a sua contribuição monetária ao partido, e para arcar com essas e demais despesas, solicitava envio de dinheiro ao irmão Bunji, pois o que ele ganhava escrevendo mal dava para o sustento. Comparecia raras vezes à universidade, até que acabou desistindo dela, mas não comunicou o fato ao irmão. Dazai precisava de um álibi para que o irmão continuasse a lhe enviar o dinheiro. Só anos mais tarde é que o irmão Bunji tomou conhecimento dos atos de Dazai.

\section{Primeiras Obras de Dazai}

No começo de 1933, Dazai, com apoio de outro escritor, Kon Kan'ichi, foi introduzido no círculo de jovens escritores. Esse grupo já estava engajado em publicações literárias no jornal Kaihyô (Leão Marinho). Essa interação foi a primeira prova frutífera na vida literária do escritor iniciante Dazai. Nesse grupo, ele 
encontrou veteranos escritores, como Dan Kazuo e Yamagishi Gaishi, e nesse jornal, Dazai conseguiu o apoio para a publicação de Omoide (Lembranças). Desde então, Dazai ficou sendo um membro regular do círculo literário. Além de Dan Kazuo e Yamagishi, constavam também veteranos, como Ima Harube, Nakamura Jibei, Kitamura Kenjirô.

As obras de Dazai foram bem recebidas pelos leitores de Leão Marinho, e desde então, ele começou a despontar como um proeminente escritor no mundo literário de Tóquio. Apesar do glamour literário de Tóquio, Dazai nunca se esqueceu da sua terra natal, Tsugaru, e tudo que se referia à sua terra tinha uma importância ímpar para ele. Quando o jornal Tôô Nippô (Notícias Diárias de Norte), de Tsugaru, patrocinou um concurso literário para os escritores nascidos lá, Dazai foi inscrito como um legítimo filho de Tsugaru, tendo sido premiado com a obra Ressha (O Trem).

Em 1935, Dazai teve peritonite, e durante a sua internação ele viciou-se no medicamento Pabinal. No mesmo ano, ocorreu a segunda tentativa fracassada de suicídio.

Dazai foi grande leitor da Bíblia, e a influência do Cristianismo está presente em suas obras, como em Pôr-do-Sol, onde se encontra um grande número de citações do Evangelho Segundo São Mateus. Para justificar o seu conhecimento religioso, necessário se faz um breve relato.

Em 1936, Dazai foi internado no hospital de Shiba Akabane Chô, para a desintoxicação de Pabinal. Tão logo ele recebeu alta, seguindo o conselho do seu mentor, Ibuse Masuji, Dazai internou-se em outro hospital, Itabashi Ekoda, e lá permaneceu por um mês. Nesse período de internação ele tomou contato com a Bíblia e leu o Novo Testamento. Segundo Takeo Okuno (1968):

Dentre os escritores contemporâneos, talvez não haja um como Dazai que tenha lido a Bíblia com tanto afinco. Ao ler a sua obra, o leitor se depara com as palavras do evangelho com naturalidade e começa a questionar se as citações da Bíblia não seriam do próprio autor. Pelas leituras do trecho referente à Bíblia, pode se sentir como a palavra sagrada penetrou no seu coração. (OKUNO, 1968, p. 55, tradução nossa) 
Ainda segundo Okuno, Dazai teria se espelhado no autor russo Dostoiévski, que, preso na Sibéria durante quatro anos, voltou-se para a leitura da Bíblia. Tendo como destino certo a morte, Dostoiévski teria se apegado às palavras sagradas.

Em 1938, a família de Dazai contatou o consagrado escritor Ibuse Masuji, por quem Dazai tinha grande admiração, para que fosse o intermediário no omiai (casamento arranjado). Ibuse apresentou-Ihe a professora Ishihara Michiko, de 26 anos, da cidade de Kôfu, na província de Yamanashi. Em 08 de janeiro de 1939, eles se casaram na casa de Ibuse, em Tóquio.

A nova estabilidade familiar garantiu a Dazai o seu primeiro prêmio literário em Tóquio, pelo trabalho Ôgon Fûkei (Cenário Dourado). Outro prêmio, Tôkoku, foiIhe aferido pela obra Joseito (A Estudante). Assim, Dazai rodava o país, a fim de atender aos pedidos das universidades, como palestrante. Sabe-se, contudo, que a grande finalidade dessa jornada seria a coleta de materiais para as suas histórias.

\section{Consolidação como Escritor e Atividades Durante a Guerra}

A extinção da literatura política de esquerda ocorreu com a morte de Kobayashi Takiji, em 1933, após a polícia tê-lo torturado durante um interrogatório. Esse foi o estopim para os exemplos mais notórios desse período, que conduziram os literatos para a conversão ideológica (Tenkô) aninhados sob as "asas" da linha governamental da direita.

Em 1934, a Revista Trimestral do círculo de Dazai publicou dois contos de sua autoria: no primeiro número, Ha (Folhas), e no segundo número, Sarumen Kaja (Cara de Macaco). A revista Seiki (Século) publicou a obra Kare wa Mukashi no Kare Narazu (Ele Não é Mais o Mesmo Homem).

Em dezembro de 1934, Dazai e os amigos Yamagishi Gaishi, Dan Kazuo, Ima Harube, Kon Kan'ichi, Kitamura Kenjirô e o poeta e crítico Nakahara Chûya 
desligaram-se da Revista Trimestral e fundaram a revista Aoi Hana (Flores Azuis), inicialmente com forte influência da Escola Romântica, da qual se desligaram no ano seguinte. Pode-se dizer que a consolidação de sua carreira teve início no começo de 1938, aos 29 anos, quando ele decidiu que seguiria a carreira de escritor.

No começo do ano de 1939, o jornal Kokumin Shimbun (Notícias Nacionais) concedeu a Dazai um prêmio pela sua obra Ôgon Fûkei (Cenário Dourado). Após o recebimento do prêmio, Dazai foi para as termas de Izu e depois para o resort de Kamisuwa, localizados na província de Shizuoka, no intuito de tratar da sua saúde.

Dazai nutria uma atração especial pela Península de Izu, que tem uma importância histórica para o Japão. No período Edo (1603-1868), era um ponto de parada dos viajantes entre a antiga capital Quioto e Tóquio (antiga Edo).

Em julho de 1940, Dazai voltou à Izu, onde escreveu Tôkyô Hakkei (Oito Vistas de Tóquio), obra publicada em 1941. Em novembro do mesmo ano, fez uma visita à Ilha Sado e escreveu, posteriormente, o conto Sado (Sado). Em 1941, Dazai voltou novamente a Izu, ocasião em que escreveu Shin Hamuretto (O Novo Hamlet). Visitou também o Monte Fuji.

A peregrinação de Dazai abrangia locais turísticos e históricos do Japão. Da sua jornada nascia a sensibilidade de extrair do tempo e do espaço ferramentas para a criação literária. Essa viagem inspirou-lhe a escrever Kokyô (Terra Natal). Em novembro de 1941, Dazai recebeu a convocação para servir o exército, mas acabou sendo dispensado devido à sua debilitada saúde.

Mesmo durante o conflito mundial, Dazai conseguia dedicar-se à sua produção literária. As obras Shinrô (Os Recém-Casados) e Jûnigatsu Yôka (Oito de Dezembro) são desse período. Em 1942, o conto Hanabi (Fogos de Artifício) foi censurado e publicado no pós-guerra sob o novo título Hinode Mae (Antes do Amanhecer). Nesse mesmo ano (1942), Udaijin Sanetomo (Sanetomo, Ministro da Direita), que relata a história do xogun Sanetomo, foi concluído na província de Shizuoka. 
Em 1943, como resultado da maturidade literária de Dazai, após ter escrito a obra Fugaku Hyakkei (Cem Visões do Monte Fuji, 1939), é publicada pela Shinchôsha, uma das maiores editoras do Japão. A obra é mencionada em Shôwa Meisaku Zenshû (ObrasPrimas de Shôwa) como uma das melhores da literatura do período Shôwa (1926-1989).

Uma vez finalizada a guerra, o problema de colaboração com as autoridades durante a guerra foi um dos maiores problemas enfrentados pelo mundo literário japonês. Muitos escritores que contavam com o respaldo de direitos autorais, e que tinham o seu próprio rendimento durante a dura fase da guerra, obedeciam aos apelos das autoridades para a conversão, permanecendo em completo silêncio. Dazai, como poucos escritores, ficava à margem da dúvida se ele aceitaria a situação imposta pela autoridade ou continuaria com a sua liberdade de expressão criativa e repressão pela força governamental. Sendo a imposição da autoridade maior, Dazai foi obrigado a aquiescer com a situação prevalecente. Uma vez terminada a guerra, Dazai deixou claro que a sua lealdade ainda estava com o povo japonês e que ele agia em consonância com as suas crenças naquilo que fosse necessário.

Dazai (1946) escreveu:

O Japão se rendeu incondicionalmente. Tudo que senti foi vergonha. Eu estava tão envergonhado que não pude dizer nada. $O$ número de pessoas que tinha coisas péssimas a dizer sobre 0 Imperador crescia dramaticamente. Mas quando eu vi o que estava acontecendo, percebi o quanto amava o Imperador. Eu proferi então, o meu ponto de vista conservador para os meus amigos. (apud LYONS, 1985, p.44, tradução nossa)

Dazai tinha selado sua política de paz com o governo para evitar que suas publicações fossem censuradas quando deixou o mundo político da esquerda e passou a se dedicar mais à vida pessoal. Agora ele estava encontrando a sua própria voz em suas obras, sem ser influenciado pelas correntes da esquerda. Para que Dazai não fosse contaminado pelas mazelas da guerra, ele foi buscar inspiração em trabalhos clássicos da Literatura Japonesa. Com o objetivo de atestar esssa intenção de não retratar a crueldade quotidiana do conflito, a maioria dos seus trabalhos desse período (durante a guerra) mantém certo distanciamento da realidade, 
enfatizando mais a literatura ficcional, evitando, assim, introduzir em suas narrativas experiências diretas da guerra.

Na obra Udaijin Sanetomo (Sanetomo, Ministro da Direita), o tempo e o espaço referem-se ao século XIII, e a história foi baseada na crônica Azuma Kagami (O Espelho do Leste), sobre a vida do terceiro xogun de Kamakura, Minamoto Sanetomo (1192-1219). De acordo com Donald Keene (1998), Sanetomo foi um tema popular de estudos durante a guerra devido à sua dupla carreira como guerreiro e poeta, o que inspirava figuras literárias no período da guerra. Dazai fez uso desse recurso para criar o retrato ideal de aristocrata, fazendo com que se admirasse Sanetomo como xogun. Algumas vezes a fala de Dazai assemelha-se à fala de Sanetomo, quando esse diz, segundo Lyons (1985, p. 44): "[...] saquê foi feito para se embebedar. Não tem outro mérito." Contudo, Sanetomo representa ideais que Dazai nunca tentou imitar. O método em que Dazai se baseava era o de citar alguns trechos do original de Azuma Kagami e de dar a sua própria interpretação às descrições originais, no caso da visita que Kamono Chômei ${ }^{10}$ fez a Sanetomo no décimo mês do ano 1211 (mencionado em apenas duas linhas de Azuma Kagami). Nos relatos de Chômei, a visita foi descrita em oito páginas. Essa visita consistia de perguntas feitas por Sanetomo e respondidas por Chômei. Uma dessas perguntas seria o que Chômei admirava na poesia de Sanetomo e o conselho dado pelo primeiro ao segundo sobre as influências sofridas pelos poetas da Corte. $O$ narrador que presenciou a conversa dos dois relata que havia possibilidades de que a visita feita por Chômei a Sanetomo tivesse inspirado o primeiro a escrever Relatos da Minha Cabana (o mais famoso trabalho de Chômei), e, finalmente, qual efeito teve o conselho dado por Chômei a Sanetomo.

O narrador relata que o auge da carreira de Sanetomo foi o período dos 20 aos 21 anos de idade. Logo após, ocorreram rebeliões populares que ameaçaram a

${ }^{10}$ Poeta e crítico de poesia, ele é conhecido também pelo seu ensaio Hôjôki (Relatos da Minha Cabana), escrito em 1212. Nesse trabalho Chômei enaltece com grande beleza de estilo sua conviç̧ão de que ser eremita era a única possibilidade de se refugiar dos desastres do mundo. Em todo o seu trabalho, Chômei utilizou a imagem da casa para representar a vaidade do ser humano. Ele descreve a dor das pessoas que perderam suas casas em terremotos, conflagrações ou tempestades e por outro lado a alegria de um eremita cuja cabana é uma moradia modesta e temporária que mesmo sendo destruída pelas intempéries da natureza não the traria nenhum aborrecimento. (KEENE, 1999, p.759. tradução nossa). 
sua autoridade. Apesar da sua generosidade em perdoar os rebeldes, a desordem social era crescente, e Sanetomo foi perdendo interesse pela política do Estado, dando início ao alcoolismo. Entretanto, apesar da sua profunda apatia, ele sempre mantinha imenso respeito pelos deuses e pela família imperial. Dazai insistia em negar que fora afetado pela ideologia do período da guerra. O tema da obra Sanetomo, o Ministro da Direita identifica-se com Dazai por ele ter dado à obra um tom autobiográfico. Além do mais, ele era um admirador da indiferença às convenções aristocráticas de Sanetomo. Aventa-se a idéia de que essa sua indiferença às convenções sociais originou a criação do romance Pôr-do-Sol.

Em Shinshaku Shokoku Banashi (Reintepretação de Relatos das Províncias), há uma releitura da obra de Ihara Saikaku intitulada Saikaku Shokoku Banashi (Relatos de Províncias de Saikaku, 1685), uma das mais notáveis do século XVII.

Dazai fez também adaptações baseadas em Otogizôshi (Fábulas), uma coletânea de narrativas da época Muromachi voltadas para o entretenimento. Otogizôshi de Dazai reúne quatro narrativas: Kachi kachi Yama (A Montanha Crepitante), Shitakiri Suzume (O Pardal da Língua Cortada), Kobutori Jiisan, (O Removedor de Calombos), Urashima Tarô (Urashima San). Essas histórias foram compostas a fim de entreter a pequena filha, que se encontrava no abrigo antiaéreo durante o bombardeio.

Mais tarde, a filha de Dazai lembra-se do pai como:

O papai estava vestido com simplicidade. Ele aparentava ser uma pessoa estúpida, mas no fundo ele era uma pessoa notável. Ele tinha dentro de si um verdadeiro e extraordinário dom de criar contos de fadas [...]. (apud LYONS, 1985, p. 46, tradução nossa)

De acordo com Donald Keene (1999), as histórias do período Muromachi foram consideradas pelos literatos como sendo uma literatura marcante do passado. $\mathrm{E}$, mesmo na era pós-guerra, o povo japonês tem demonstrado um grande interesse em Otogizôshi (Fábulas). Com o final da guerra, a democratização do Japão estava muito presente na mente do povo japonês. Sendo assim, as fábulas foram exaltadas como exemplos de "literatura do povo", e histórias como Hachikazuki, Monokusa Tarô, Issun Bôshi, Urashima Tarô, Yokobue no Sôshi e Shuten Dôji ainda estavam 
sendo lida como histórias infantis (dôwa), mesmo no Japão contemporâneo indiferente às críticas dos literatos. As atenções do povo japonês têm sido focadas em 23 histórias da coleção original de Otogi Bunko. A maior parte das histórias dessa coleção ainda permanece inacessível aos leitores em geral.

Durante o período da guerra, Dazai escreveu ainda Seigi to Bishô (Justiça e Sorriso) história baseada no diário do irmão do amigo. Nesse período, evitava escrever sobre temas polêmicos que o colocassem na mira das autoridades. Em 1944, ele escreveu Sekibetsu (Pesar da Separação), patrocinada justamente pelo governo. A história é baseada num estudante de medicina, Lu Hsün, revolucionário chinês que participara na revolta nacional chinesa contra o imperialismo japonês. Dazai, nesse período, evitava o confronto com a censura, mas segundo Lyons (1985, p.45) dizia: "[...] como eu gostaria de gritar, mas a minha voz fraca se perderia no meio desse tumulto geral...". No fundo, ele não poderia ir contra o sistema governamental, pois dependia dos recursos provenientes de suas publicações para manter a sua família. Ele não poderia ficar antagonizando ou ignorando as autoridades. Dazai diz em Ha (Folhas), segundo Lyons (1985, p. 45, tradução nossa): "A beleza da arte é, acima de tudo, servir o povo". Esse pensamento sintetiza a influência do meio em sua obra. Ele escrevia de acordo com o que a situação exigia, recorrendo ao tom ameno nas suas escritas, mas aferindo a obra à sua estética literária. Seu trabalho do período de guerra pode ser considerado propaganda de governo. Ele via o seu trabalho como um dever para tentar trazer ânimo para as vidas sombrias dos seus compatriotas.

Como todo artista tem o seu ápice, poder-se-ia dizer que o período áureo de Dazai deu-se entre 1939 e 1948. O crítico literário Phyllis Lyons (1985) refere-se à importância do Dazai no panorama literário japonês:

Estudos críticos sobre o seu trabalho transbordam nos jornais literários. Mesmo revistas populares publicam regularmente artigos sobre a sua vida. A notoriedade alcançada por Dazai iguala-se à de Elvis Presley neste país. Desde a sua morte, em 1948, têm sido editadas seis edições completas do seu trabalho. Muitas delas com diversas tiragens. Dazai é sempre mencionado em antologias da Moderna Literatura Japonesa. Suas obras são publicadas em edições das maiores publicações em circulação. Muitos dos 
renomados críticos literários detêm pelo menos um ensaio sobre o seu trabalho. (LYONS, 1985, p. vii, tradução nossa)

A Segunda Guerra Mundial foi um dos períodos mais negros para a humanidade. Entretanto, ao contrário de muitos escritores que viam os seus trabalhos decaírem nesse período devido à falta de recusos, falta de interesse pela leitura de romances e falta de criatividade dos escritores, nesse cenário de baixa auto-estima do povo japonês, Dazai manteve-se ativo e produtivo, escrevendo várias obras, inclusive para crianças. Nos anos pós-guerra, 1946, 1947 e 1948, Dazai definiu o seu estilo literário recorrendo ao Romance do Eu. E também foi nesse período que as suas obras mais significativas foram lançadas no mundo literário japonês. 


\section{Retorno para Tsugaru: o cronotopo de Dazai}

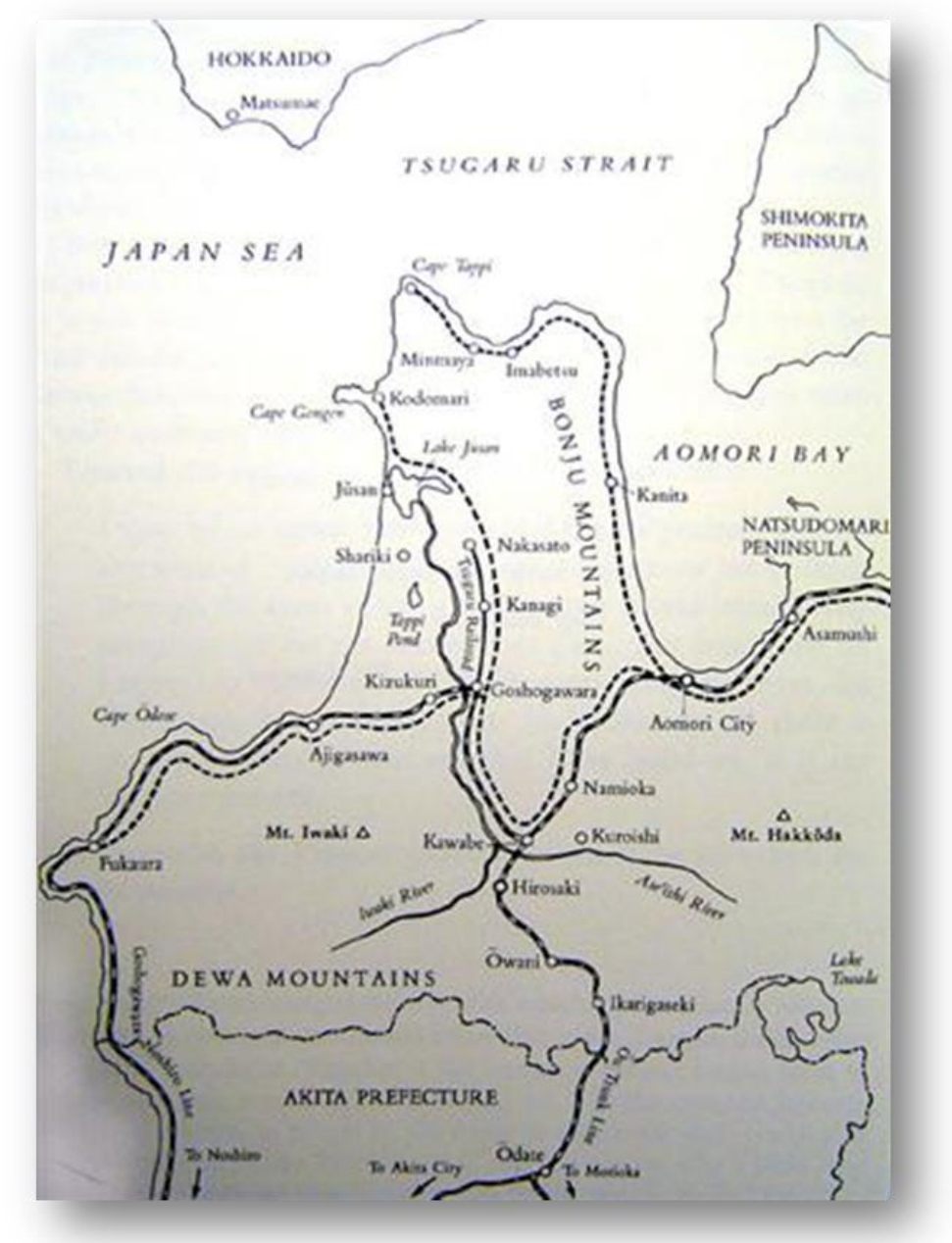

Figura 05 - Rota de Dazai: o retorno a Tsugaru Fonte: DAZAI, 1985, p. xxx.

Eu pensava que Dazai fosse a única pessoa nascida em Tsugaru que carregava no fundo da alma o aroma de família e de terra natal, mas cheguei à conclusão de que isso era uma característica especial de todo nativo de Tsugaru. (TSUSHIMA, tradução nossa). ${ }^{11}$

Em 1944, Dazai recebeu uma proposta de Koyama Kiyoshi, proprietário de Koyama Shoten (Livraria Koyama), para escrever um livro sobre Tsugaru. Dazai permaneceu na cidade de 12 de maio a 05 de junho do mesmo ano, para a coleta de material. Essa jornada foi para Dazai uma das mais significativas da sua vida. 0

\footnotetext{
${ }^{11}$ TSUSHIMA, Michiko. Omoidasu mama ni (Minhas Lembranças). Apud Lyons, 1985, p. 127.
} 
retorno à sua terra natal, o reencontro com as suas raízes, a família e os antigos amigos, tudo isso lhe tocou profundamente a alma. A obra Tsugaru (Tsugaru) foi publicada em novembro de 1944, e é o trabalho mais introspectivo do autor.

Essa obra foi narrada com um toque de humor, sem autopiedade. A narrativa é repleta de expressões carinhosas sobre aquelas pessoas que foram muito importantes na sua vida. Essa jornada ofereceu a Dazai a chance de encontrar o dialeto único de Tsugaru.

Numa das conversas com os amigos, Dazai declarou:

Sinto um desconforto comigo mesmo como um homem da cidade grande, e espero agarrar essa oportunidade de demonstrar que eu sou um nativo de Tsugaru [...] Meu estudo aqui não é Tsugaru, e sim o que o homem chama de amor, a relação sentimental mútua. (apud LYONS, 1985, p. 47, tradução nossa)

Nessa sua jornada, reencontrou amigos de infância que haviam permanecido em Tsugaru, como Nakamura Teijirô, que teria sido o modelo do personagem ' $N$ 'em Tsugaru. Visitou também Nakabata Keikichi, amigo íntimo da família. Apesar da distância, Nakabata Keikichi sempre esteve atento aos passos do amigo Dazai durante sua escalada em Tóquio. Durante essa jornada sentimental, o clímax emocional foi o reencontro com sua antiga ama seca, Take, após trinta anos de separação.

O reencontro com Take

Tsugaru é um romance autobiográfico que mescla realidade e ficção, uma rememoração literária da própria existência. 


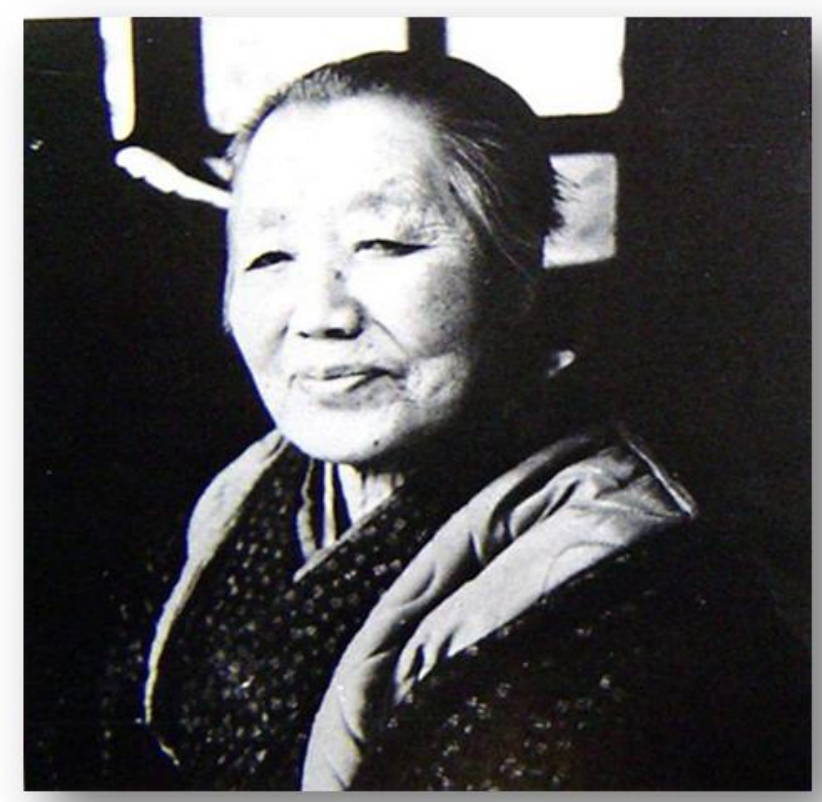

Figura 06 - Take com idade avançada. ${ }^{12}$ Fonte: DAZAI, 1985, p. 98p.

Numa das passagens de Tsugaru narra-se o reencontro do escritor com a antiga ama, Take. Ao se encontrarem, ficam mudos, e o silêncio foi preenchido pela emoção. Os dois caminharam para o templo do Deus Dragão, e Take confessou, em lágrimas, que sentira muitas saudades dele. Dazai passou uma noite na casa de Take na cidade de Kodomori. Era a oportunidade que ele precisava para ficar sozinho com a antiga babá.

Ele perguntou a Take:

"- Eu sou realmente irmão de Bunji? - E continuei. Eu não sou filho da tia Kie?."

Take respondeu:

"- É verdade que a sua tia Kie Ihe criou, mas quem Ihe deu à luz foi sua mãe, Tane, e você é irmão legítimo de Bunji."

12 Explicação original da foto: "Take em idade avançada. 'Talvez eu seja tendencioso, mas parece-me que Take é melhor que as outras mães dessa aldeia". (DAZAI, 1985, p. 98p, tradução nossa).

Fotografia cedida por Koshino Take 
Nessa época, Dazai estava com quase 35 anos. Durante toda a sua vida, sentira-se atormentado pelas circunstâncias do seu nascimento.

As raízes

Dazai encontrou a sua raiz, a origem de tudo, em Tsugaru, mas antes precisou exilar-se em terras distantes e peregrinar pelos espaços mais variados, como Tóquio, Izu, Niigata, para que ele pudesse achar a essência da sua vida. Seu olhar sobre Tsugaru é romantizado, não um olhar realístico.

É inegável que o apego do autor pelo local em que passou a sua infância tenha um valor sentimental, e isso pode estar ligado a uma gaveta, uma porta ou um retrato, conforme Gaston Bachelard:

\footnotetext{
Para analisar nosso ser na hierarquia de uma ontologia, para psicanalisar nosso inconsciente entrincheirado nas moradias primitivas, é preciso, à margem da psicanálise normal, dessocializar nossas grandes lembranças e atingir o plano dos devaneios que trazíamos conosco nos espaços de nossas solidões. Para tais indagações, os devaneios são mais úteis que os sonhos. $\mathrm{E}$ tais indagações mostram que os devaneios podem ser bem diferentes dos sonhos. (BACHELARD, 1979, p. 203)
}

Tudo é justificável para a longínqua jornada de Dazai. Como o poeta andarilho Bashô, autor de Oku no Hosomichi (Caminho Estreito Para o Longínquo Norte), que fez o registro das jornadas a pé pelo território japonês, Dazai sentiu a necessidade de retroagir no tempo para explicar o espaço do presente.

A importância da descoberta de suas raízes em Tsugaru fica evidente na obra Jûgonen Kan (Durante Quinze Anos):

O que eu descobri durante essa jornada foi a rudeza, a maneira desajeitada e rústica de Tsugaru. A inépcia de se expressar culturalmente. Senti também a mesma inépcia em mim próprio. Mas, ao mesmo tempo, senti algo saudável. Daqui não surgiria uma cultura (tenho pavor da palavra "cultura"...) nova? [...] Eu retornei para Tóquio com sentimento de autoconfiança e orgulhoso por ter nascido lá, pois nas minhas veias corre o verdadeiro caráter de Tsugaru. Em outras palavras, estou aliviado por descobrir que em Tsugaru não existe cultura, e conseqüentemente, eu, 
como cidadão de Tsugaru, não sou uma "pessoa com cultura". Sinto que as histórias que escrevi após essa descoberta são um pouco diferentes das que escrevi até então. (DAZAI, 1985, p. XXVII) (tradução nossa)

A descoberta de que em Tsugaru não existe uma cultura (pelo menos a cultura que ele diz ter pavor) leva-o a conhecer-se melhor à medida em que ele se identifica como cidadão de Tsugaru, como se vê na obra Durante Quinze Anos.

[...] talvez eu não passe de um estúpido camponês de Tsugaru, sem nenhum senso de cultura. Eu sei que se você me visse andando com as minhas galochas sobre a neve, você me reconheceria imediatamente, por ser eu um provinciano. Mas, a partir de agora, pretendo cultivar o meu modo desajeitado e provinciano e simples de ser. Se existe algo no próprio eu atual, que eu possa construir de agora em diante, será o camponês de Tsugaru. (DAZAI, 1985, p. XXVIII)

Infelizmente, o camponês de Tsugaru não se deu com os demônios que moravam em Dazai. Ele conseguiu harmonizar o tempo e o espaço através da busca de suas raízes na longínqua terra natal, mas antes ele precisou cultivar o exílio de Tsugaru e aventurar-se na jornada de diversas terras distantes para encontrar o seu verdadeiro Eu. Dazai, ao mergulhar no passado, conseguiu explicar o seu presente. Ele precisou retornar às origens para desvendar o fantasma da infância que durante toda a vida o perseguiu, levando-o a angustiar-se, pois a sua mente estava recheada de dúvidas, vividas durante a sua infância, por desconhecer quem seria a sua verdadeira mãe. Seria Take, Tane ou Kie? Essa dúvida indelével que ficou gravada na sua memória durante longo período de sua vida, foi decifrada somente na sua vida adulta, cuja existência na Terra, teve curta duração.

\section{A obra inacabada}

Na noite do dia 13 de junho de 1948, Dazai desapareceu. Deixou inacabados os capítulos 10, 11 e 13 de Guddobai (Adeus), além de muitos bilhetes para seus amigos e familiares, sendo um, em especial, para o seu velho e íntimo amigo Ima Harube. Os corpos de Dazai e Yamazaki Tomie, a amante que o acompanhou para cometer suicídio, mais tarde apelidada de (O Anjo da Morte) foram resgatados do 
canal Tamagawa na manhã do dia 19 de junho de 1948 . Era o seu $40^{\circ}$ aniversário. Suas cinzas permanecem no templo Zenrinji, perto da sua casa, em Mitaka. Seu túmulo fica em frente ao de Mori Ôgai, autor admirado por Dazai.

Para homenagear Dazai, realizam-se todos os anos, no templo Zenrinji, o culto denominado Ôtô ou Memorial de Cerejeiras, em alusão à última obra escrita pelo autor Ôtô (Cerejeiras). Em outubro de 1953, um monumento comemorativo foi erguido na estação Misaka, em frente ao Monte Fuji, e em 1956, no monte Kanran. O jornal Tenbô publicou a obra Desqualificado Como Ser Humano no ano da sua morte. O mesmo jornal estabeleceu o prêmio Dazai Osamu, em 1965. No mesmo ano, também Kanagi foi reconhecida oficialmente como cidade natal de Dazai. Finalmente Tsugaru ficou conhecida em todo o Japão e pelos estrangeiros através do seu mais ilustre filho, Dazai Osamu.

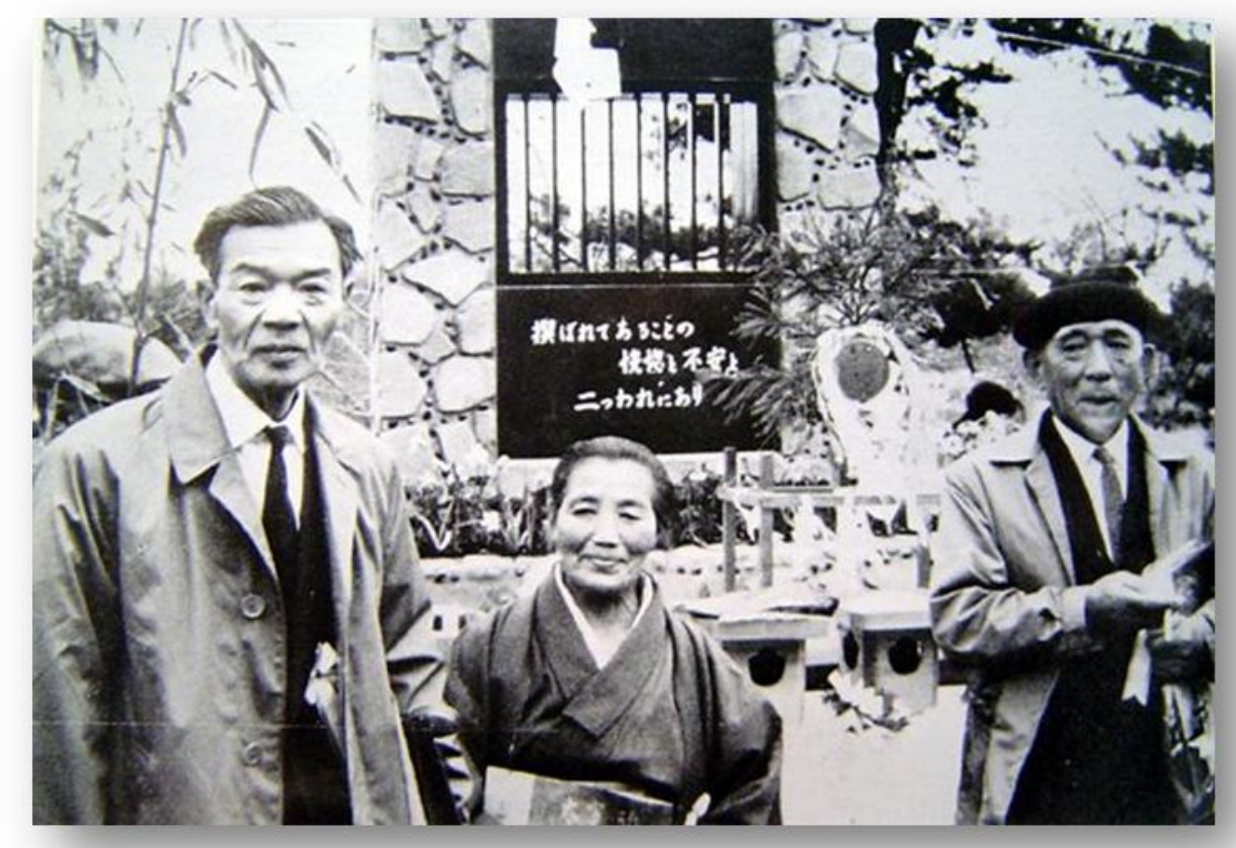

Figura 07 - Nakamura Teijirô, Koshino Take e Nakabata Keikichi no Memorial de Dazai. ${ }^{13}$ Fonte: DAZAI, 1985, p. 98p.

13 Explicação original da foto: "Nakamura Teijirô [o personagem ' $\mathrm{N}$ ' de Tsugaru], Koshino Take, e Nakabata Keikichi em visita ao Memorial de Dazai no Parque Ashino, Kanagi, em 1965. A inscrição e a tradução da frase favorita de Dazai: 'Eu tenho êxtase e eu tenho terror de ser escolhido; os dois sentimentos vivem dentro de mim'. (Verlaine, Sagesse)." (DAZAI, 1985, p. 98p, tradução nossa). Fotografia cedida por Ono Masafumi. 


\section{Atividades no Pós-guerra}

Após a guerra, os dois maiores romances de Dazai, Pôr-do-Sol (1947) e Desqualificado Como Ser Humano (1948), tiveram grande sucesso, e Dazai alcançou enorme reputação.

De certa maneira, a geração dele diferia daquela de Kafû, Tanizaki e Kawabata. Dazai possuía uma formação ocidental e eclética, tendo consciência de que recorria a métodos ocidentais na composição dos seus trabalhos. Tinha influências de Dostoiévski, Tchekhov e do Naturalismo francês. Além do mais, era um profundo conhecedor da arte e literatura ocidental. $O$ fenômeno de popularidade dele no pós-guerra foi impressionante. O desespero e niilismo romântico expressados na obra Pôr-do-Sol foram reconhecidos pelos críticos como sendo o estilo irrefutável de Dazai.

Dazai pertencia ao que se pode ser chamado de terceira geração de modernos escritores japoneses. A primeira geração fez um grande movimento em prol de novos temas literários. No final do século XIX, novas técnicas de narrativa foram utilizadas com a entrada de obras ocidentais no Japão. Nesse período, para alguns escritores a palavra "ocidental" era modelo de ser moderno.

Nos anos 1880, escritores e críticos, como Tsubouchi Shôyo e Futabatei Shimei, estavam ainda assimilando a nova linguagem literária. Dentro de pouco tempo, um número considerável de escritores passou a viver no exterior, com o objetivo de experienciar a modernidade ocidental. O escritor Mori Ôgai estudou na Alemanha enviado pelo exército nos meados de 1880 ; Natsume Sôseki foi enviado a Inglaterra pelo governo, no período de 1901 a 1903; Nagai Kafû foi enviado pela família aos EUA (1903 a 1907) e depois foi para a França (1907).

Estes e outros autores centralizaram as suas atenções num novo tipo de personagem literária: um homem comum, solitário e perplexo perante a sociedade, algumas vezes, mal-compreendido. 
Durante a época da segunda geração, nos anos de 1910 a 1920, a modernização foi aceita pelos escritores como um fato consumado. Nos romances japoneses, a comparação entre o Ocidente e o Oriente era inevitável. Os leitores viam essa transformação como modernidade. Com a modernidade o passado da própria cultura estava sendo relegado ao segundo plano.

A preocupação dos escritores da escola romântica era com a descoberta da individualidade dos autores. A preocupação do Naturalismo estava na posição do crescimento isolado do indivíduo na sociedade. O objetivo das escolas literárias estava voltado para a criação literária baseada na concepção de "arte pela arte".

Os principais escritores da segunda geração literária são Shiga Naoya, Arishima Takeo, Tanizaki Jun'ichirô, Satô Haruo e Akutagawa Ryûnosuke, e mais tarde vieram os neo impressionistas, como Yokomitsu Riichi e Kawabata Yasunari. Mas, naturalmente, passaram por várias fases durante sua atividade literária. Tanizaki, por exemplo, começou a publicar em 1910, e escreveu até a sua morte, em 1965.

Quando Dazai estava ascendendo em sua carreira, nos anos 1920 e no começo de 1930, muitos desses escritores da segunda geração já eram famosos. Dazai começou dentro do movimento literário proletário, que era muito mais uma perspectiva social do que uma escola ou corrente literária. No início da carreira de Dazai, a literatura proletária estava no seu auge, no final dos anos de 1920, e ele foi o primeiro literato a enfrentar o desafio em termos da literatura proletária. Os políticos de direita e a censura dos anos '30 puseram fim às agitações e exortações sociais do movimento proletário. Nessa época, Dazai tinha se afastado do envolvimento político de qualquer natureza.

Dazai ainda estava engatinhando no mundo moderno, mas aos poucos foi ganhando reconhecimento. Nomes de escritores ocidentais, como Ibsen, Strindberg, Verlaine, Baudelaire, Tchekhov, Tolstoi e Dostoiévsky são freqüentemente citados em suas obras sem explicação ou somente como uma referência alusiva, como se fossem familiares aos leitores. 
No Japão, todos os caminhos literários levam a Tóquio. Todas as publicações literárias estavam concentradas na capital, e no início de sua carreira, Dazai foi rotulado como sendo o "intelectual provinciano de Tsugaru que veio para a grande metrópole".

Os escritores novatos tinham que ter um mentor para serem patrocinados mesmo que o patrocínio não fosse formal. Havia diversos mentores na carreira de Dazai, incluindo Ibuse Masuji e Satô Haruo. Com este último, Dazai tinha um relacionamento conturbado. Os escritores novatos eram criticados pelos mais poderosos, como Kawabata e Shiga (Dazai chamava-os ironicamente de rôtaika, grandes escritores veneráveis). Dazai nunca pertenceu seriamente a uma escola. Se pertenceu, foi por um breve momento em qualquer delas, mas colecionou um público de devotados, fiéis editores e leitores. Alguns dos seus amigos mais íntimos eram escritores, mas a sua relação com o Bundan era distante.

\section{O Romance do Eu e a sinceridade de Dazai}

Dazai, em sua trajetória, pertenceu a diversos movimentos literários, iniciando na escola romântica japonesa, depois na Burai-ha (Corrente dos Decadentes), Hametsugata (Corrente de Autodestruição) e Watakushi Shôsetsu (Romance do Eu). Mas em sua história autobiográfica fica evidente que o gênero que mais influenciou suas obras foi o Romance do Eu.

O Romance do Eu é uma corrente dominante na Moderna Literatura Japonesa desde 1907. O marco acontece com a publicação de Futon (O Acolchoado), de Tayama Katai. No Romance do Eu, em primeira ou terceira pessoa, existe uma clara identificação entre os fatos narrados e os fatos da vida do autor.

Embora alguns críticos contemporâneos considerem a história de Dazai como auto-indulgente, James O'Brien (1981, p. 16) entende que Dazai buscava escrever através do registro e do seu próprio senso das coisas, ou seja, analisando o mundo através de sua própria vivência. Dazai contribui bastante para esse gênero literário, e 
a mensagem que transmite é dotada de humor mordaz e ironia. Segundo o crítico Gotô Meisei, os trabalhos de Dazai eram tidos como uma "paródia do Romance do Eu", como se existisse uma "quarta pessoa" narradora observando o escritor, e este, por sua vez, observando o personagem ${ }^{14}$.

Com o acirramento da guerra, iniciou-se um processo de falências de várias empresas, incluindo várias no seguimento jornalístico e editorial. Esse desastre financeiro repercutiu em forma de escassez de recursos monetários para Dazai. Outro elemento que contribuiu para as dificuldades enfrentadas por Dazai foi a censura implacável sobre seus trabalhos. E nesse contexto caótico, Dazai inicia uma nova relação amorosa com a amante Ôta Shizuko. Segundo Chiba Sen'ichi (1988), o diário particular de Ôta Shizuko, denominado por ela mesma como Shayô Nikki (Diário de Pôr-do-Sol), serviu de inspiração para criação da obra Shayô (Pôr-do-Sol).

Segundo James O'Brien (1981, p 186), Dazai era um produto da sua era, e em especial do período da guerra presenciada por ele. Com a publicação da obra Pôr-doSol, em 1947, o autor provocou entre os leitores o sentimento de nilismo pósguerra. De fato, Dazai inspirou o uso da palavra Shayô (Pôr-do-Sol) entre os seus leitores, e a partir daí, deu-se origem à palavra Shayôzoku (Tribo do Pôr-do-Sol), em referência ao grupo da aristocracia empobrecida. A palavra Shayôzoku, atualmente, pertence ao conjunto de verbetes encontrados nos dicionários da língua japonesa. Muitos críticos ressaltam que a vida e a obra de Dazai estão intimamente entrelaçadas, e quanto mais o leitor mergulha na vida do autor, mais ele se convence dessa premissa.

No romance Pôr-do-Sol, essa "família" fictícia é representada pelos três sobreviventes: a mãe, a última da linhagem aristocrática, uma classe que se extinguira no pós-guerra; Naoji, seu filho, um intelectual de esquerda viciado em entorpecentes; e Kazuko, sua filha, que busca lutar e adaptar-se aos novos tempos que inevitavelmente ela terá que encarar. A criação literária de Dazai alcança seu auge especialmente após a publicação do Pôr-do-Sol. O seu reconhecimento como a

\footnotetext{
${ }^{14}$ Gotô atribui o termo "quarta pessoa" a Yokomitsu Riichi.
} 
mais importante voz da literatura moderna japonesa ecoou por todo o território japonês.

No entanto, junto com a fama veio também a pressão das editoras, com cobranças de mais produções. Dazai, que tinha um histórico de embriaguez constante, começou a exagerar nas bebidas. Nesse mar de turbulências, com insatisfações pela pressão das editoras e pelo excesso de trabalho, Dazai concluiu, em maio de 1948, Ningen Shikkaku (Desqualificado Como ser Humano), que, depois de Pôr-do-Sol, foi o trabalho que mais projetou o autor no mundo literário.

Segundo Keene:

[...] No severo jornal de crítica literária Times Literary Suplement, fizeram comentário de que Desqualificado Como Ser Humano alcançou um alto grau de rudeza irônica típica do estilo de Dazai. E vai mais longe. $O$ autor japonês foi comparado ao autor russo Dostoiévski, no quesito concernente ao trabalho consumado de arte. (KEENE, 1972, p. 186, tradução nossa)

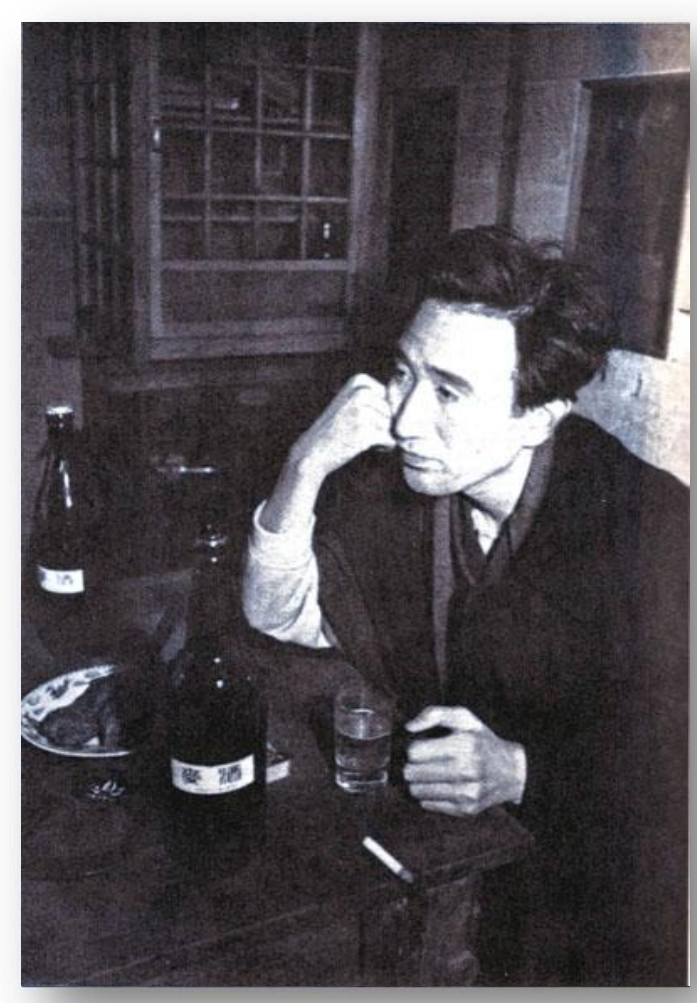

Figura 08 - Dazai: a arte imita a vida. ${ }^{15}$ Fonte: LYONS, 1986, p. 76.

${ }^{15}$ Dazai após ter escrito (Pôr-do-Sol), em 1947. 
O trabalho de Dazai atravessou fronteiras, como se ele fosse a metonímia do Japão. Segundo Phyllis Lyons (1985, prefácio), ler Dazai é ver o Japão por dentro, em suas nuances do cotidiano, de seu povo e seus costumes. É como sentir um lugar de sentimentos extremos, como uma casa de pessoas com laços fortes entre si, mas de necessidades conflitantes. Diferentementes das de Kawabata e Mishima, autores consagrados pelo público ocidental, as histórias de Dazai não contemplam elementos ficcionais ou que extrapolam o senso cotidiano, como terroristas ultranacionalistas, princesas lésbicas, monges insanos que incendeiam templos ou velhos que se deitam com ninfetas drogadas. As obras de Dazai são literalmente baseadas em fatos reais, comuns aos japoneses em seu cotiadiano, muitas vezes contendo personagens com nomes de pessoais reais. Esses personagens externam angústias, frustrações, inseguranças e crises existenciais. Amam uns aos outros e também brigam. Ironicamente, torna-se uma dificuldade exportar tal material familiar de uma cultura à outra sem as devidas adaptações sócio-culturais. Por isso, há uma grande dificuldade em traduzir o que se passa na mente do autor para leitores ocidentais. Mesmo assim, Dazai não é taxado como um escritor oriental exótico ou obscuro. 


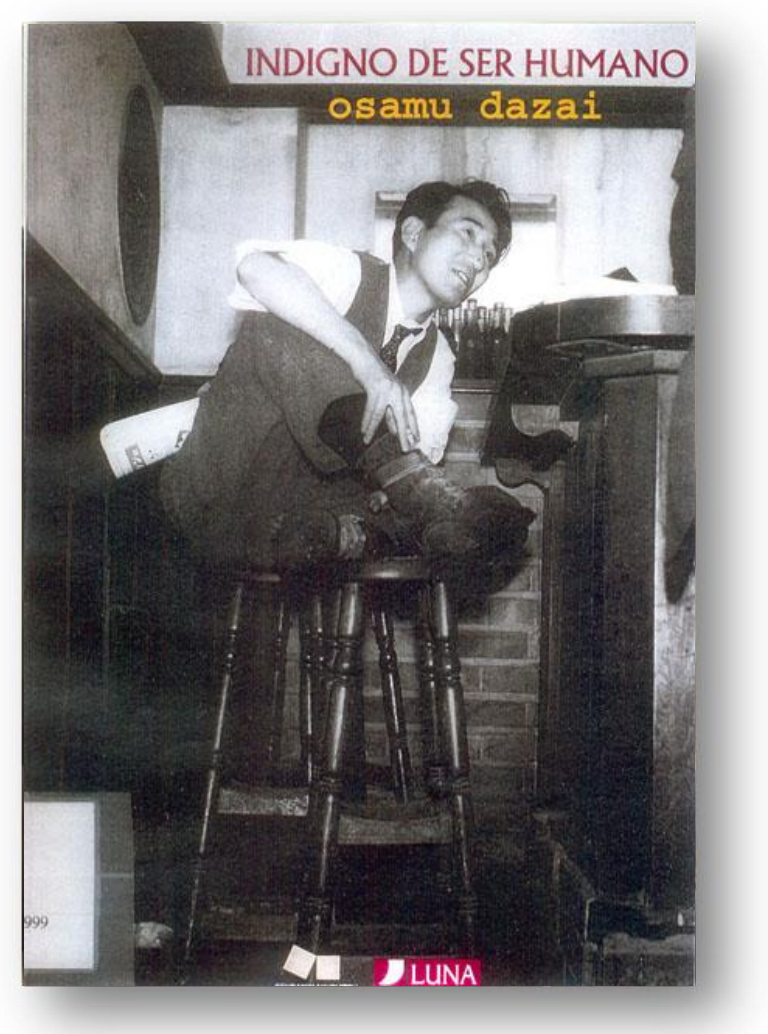

Figura 09 - Desqualificado Como Ser Humano (Ningen Shikkaku). ${ }^{16}$ Fonte: DAZAI, 1999.

Para registrar o nível de aceitação da obra de Dazai entre os estudantes das quatro maiores universidades do Japão, foi feita uma enquete no pós-guerra, segundo relata Lyons (1985, prefácio). A obra que mais influenciou os estudantes universitários foi Desqualificado Como ser Humano, ocupando o nono lugar na pesquisa feita por um dos jornais mais importantes do Japão, o Asahi Shimbum. Outras obras que tiveram grande influência sobre os jovens universitários japoneses foram Guerra e Paz, de Tolstoi; O Estrangeiro, de Alberto Camus; e Crime e Castigo, de Dostoiévski.

Em fevereiro de 1947, houve o declínio da vida pessoal de Dazai. Ele foi à cidade de Shimo Soga, em Izu, e lá passou os dias com sua amante Ôta Shizuko. Durante sua estadia nessa cidade, Dazai começou a escrever Pôr-do-Sol.

\footnotetext{
${ }^{16}$ Foto utilizada na capa de "Indigno de Ser Humano", na versão em espanhol. (DAZAI, 1999). Fotografia de Tadahiko Hayashi.

Explicação original da foto: "Dazai em um bar de Ginza, outono de 1947". (DAZAI, 1985, p. 98d, tradução nossa).
} 
A amante de Dazai, Ôta Shizuko, como se viu, mantinha um diário intitulado Diário do Pôr-do-Sol. Segundo os críticos, Dazai tinha em mente Shizuko ao criar as personagens Kazuko em Pôr-do-Sol, e Kazue em Fuyu no Hanabi (Fogos de Artifícios de Inverno). Os outros personagens de Pôr-do-Sol, Naoji e Uehara, nasceram da própria imaginação e experiência do autor.

Nohara Kazuo (1980) afirma que Kazuko foi inspirada em Ôta Shizuko. Ôta nasceu em 1913, na cidade de Echigawa, localizada na província de Shiga, em Kyûshû. Estudou o colegial na cidade de Echigawa, transferindo-se posteriormente para o colégio de Tóquio, no bairro de Shibuya. Casou-se com uma pessoa de codinome " $M$ ". Mais tarde, engravidou. A criança veio a falecer, e, desolada, Ôta acabou se divorciando de " $M$ ". Para Nohara (1980), há uma similaridade entre a vida da personagem Kazuko, em Pôr-do-Sol, e a vida real de Shizuko.

Em um trecho do diário de Shizuko, segundo Nohara (1980, p.55-56), ela descreve uma conversa que teve com seu ex-marido, " $\mathrm{M}$ ", da seguinte forma:

Eu estou amando um homem. Ele retruca: Estou sabendo. Na certa deve ser o Hosoda, não é? Será que você não consegue esquecer esse cara? E essa criança no seu ventre? É dele, não é? Depois desse incidente Shizuko retornou ao seu lar junto da mãe. (Apud NOHARA, 1980, p. 55-56, tradução nossa)

Como no diário de Shizuko, na obra Pôr-do-Sol (DAZAI, 1957), Kazuko diz ao marido:

- Tenho um namorado - Certo dia fui assaltada pela melancolia por receber críticas do meu marido e, de repente, disse aquilo.

-- Estou sabendo, na certa, é o tal de Hosoda, não é? Não consegue esquecê-lo, não é?

Fiquei calada.

Esse problema surgia toda vez que aconteciam coisas desagradáveis entre nós. Pensei comigo mesma que não dava mais. É como se cortasse de maneira inadequada um tecido novo para um vestido, e não houvesse como remendar o corte errôneo, a não ser jogando fora e reiniciando tudo com tecido novo.

- Não vá me dizer que esse filho na sua barriga... (DAZAI, 1957, Apêndice B, p. 201). 
Shizuko também vivenciava as desavenças irreconciliáveis com o marido e diz que os dias tenebrosos de convivência continuaram. Dessa união nasceu a filha, Mariko, que faleceu logo em seguida. Tanto Shizuko como Kazuko carregaram essa culpa na consciência como se tivessem matado as respectivas filhas.

Ainda de acordo com Nohara Kazuo (1980), outra semelhança existente com o fato real e o romance Pôr-do-Sol é a forma de brindar cantando num ritual de Dazai com os amigos, dizendo:

A cor da estrela do amor, como a pureza do coração do homem...

A estrela solitária brilha no céu noturno...

Se imaginarmos, no fundo o coração do homem é um abismo mortal.

(Apud NOHARA, 1980, p. 74, tradução nossa ${ }^{17}$ )

Na vida real, os amigos de Dazai repetem: "Omoikondara inochigake otoko no kokoro." A semelhança em Pôr-do-Sol (DAZAI, 1957, Apêndice B, p. 233) fica exposta assim: 'Guilhotina, guilhotina, zuuuuup' - o grupo continuou a fazer ruídos, cantando a canção e brindando com os copos". Segue-se o refrão e o gesto de brindar, é reproduzido o som de atrito dos copos e ele vira a bebida de uma vez garganta abaixo, tanto na vida real como no romance, associando a semelhança entre "abismo mortal" com a "guilhotina", que é fatal.

O romance Pôr-do-So/ foi finalizado na cidade de Izu, localizada na península de mesmo nome. Nesse mesmo ano, Dazai escreveu outra história, Viyon no Tsuma (A Mulher de Villon), tendo como heroína uma mulher. Foi nessa época também que Dazai se envolveu com outra mulher, Yamazaki Tomie, a fatal e última mulher na vida do escritor, apelidada de "Anjo da Morte."

Após a publicação do Pôr-do-Sol, Dazai iniciou uma nova fase. Até 1947, o Romance do Eu predominava nas suas narrativas. Com a inserção nas histórias de um pouco da sua vida. Após Pôr-do-Sol, parece ter chegado à conclusão de que seria melhor desviar-se da verdade do que confrontá-la. A mulher passou a ser um tema recorrente e central.

17 Dan junjô no ai no hoshi no iro...

Oete yozora ni tada hitotsu...

Omoikondara inochigake otoko no kokoro. (NOHARA, 1980, p. 74) 
As personagens femininas destacam-se pela sua determinação. Embora desiludidas com relação ao homem, mostram-se determinadas a sobreviver. A derrota do Japão na guerra precisava ser simbolizada pela mulher forte e corajosa, para contrastar com os homens fracos e tomados por ódio e paralisia, imagem exibida pelos personagens masculinos nas histórias. Dazai descobre personagens femininas que conseguem sobreviver diante das grandes adversidades do ambiente e também diante da figura fraca e homens que são derrotados pela vida.

Em histórias que enfocam personagens femininas, como Pôr-do-Sol e Fogos de Artifícios de Inverno, Dazai faz uso da palavra "revolução" como uma palavra distante da política. As personagens Kazuko e Kazue falam de "revolução moral." Essa revolução dá-lhes ímpeto para quebrar o padrão convencional da moralidade. Do ponto de vista de Dazai, especialmente para o homem, a morte é imanente em uma revolução. A dedicação de Kazuko à "revolução moral" tem uma sutil diferença daquela que o jovem Shûji (Dazai) tinha buscado nas causas da esquerda no final dos anos '20 e no começo de '30.

Ao mesmo tempo, existe algo vital e palpável na revolução das mulheres, simbolizada pelo bebê que Kazuko carrega no seu ventre e também pela filha de Kazue. Pela ausência desse símbolo (maternidade), a morte era a única saída para a abstração masculina. As mulheres podiam passar por degradação. As personagens femininas, nas últimas obras, são mães. As crianças dessas mulheres não são abstratas, elas são "reféns do destino". Essas crianças são aliadas, um talismã que garante a sobrevivência das mulheres, as quais, nas últimas obras de Dazai, se vêem como vítimas mas vitoriosas.

A importância de Fogos de Artifícios de Inverno é que se mostra o desenvolvimento da personagem Kazue. Em dezenas de detalhes, Dazai nos mostra Kazue como uma escala que servira para a criação de Pôr-do-Sol. Além de a vida de Ôta Shizuko e seu diário ter sido o meio de inspiração para a criação do romance escrito por Dazai, também se extraiu inspiração da obra Jardim das Cerejeiras, de Tchekhov que tem como pano de fundo a queda da nobreza e a reforma agrária no país. 
Segundo Yanagi Tomiko (1970, p. 166):

[...] ao ler Pôr-do-Sol, não se pode deixar de relacionar Tchekhov com a obra do autor japonês. Tchekhov está intimamente ligado à criação da obra Pôr-do-Sol. Ao escrever a referida obra, Dazai tinha em mente o Jardim das Cerejeiras ${ }^{18}$ de Tchekhov. (YANAGI, 1970, 166, tradução nossa).

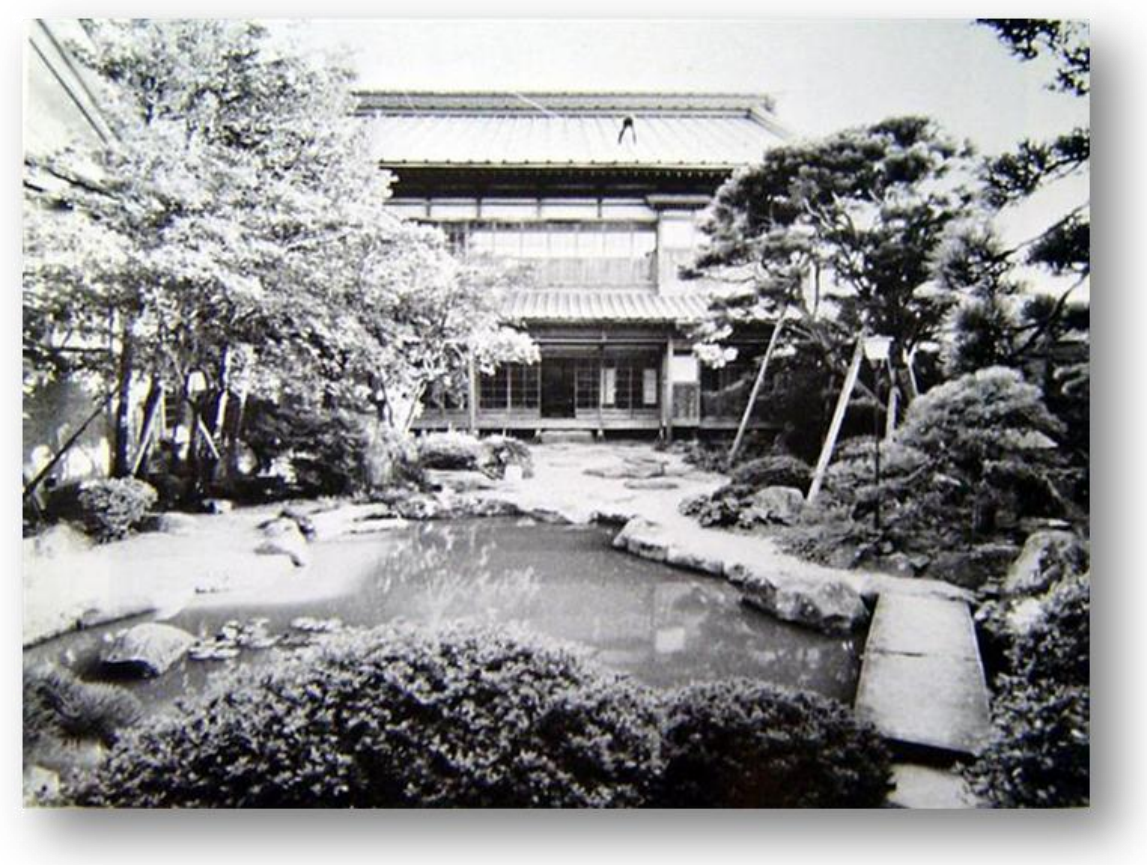

Figura 10 - Jardim do Pôr-do-Sol, na antiga casa de Dazai. ${ }^{19}$ Fonte: DAZAI, 1985, p. $98 \mathrm{f}$.

Conforme afirma Yanagi Tomiko (1970), o romance Pôr-do-Sol teria se baseado na peça de teatro de Anton Tchekhov (1904), que é um painel social da Rússia pré-revolucionária e do processo de transformação por ela sofrido a partir de 1900. Tchekhov preza algumas das qualidades da velha aristocracia: a delicadeza, e a sensibilidade.

Entre os dois romances, Pôr-do-Sol e Fogos de Artifícios de Inverno, há similaridades, a começar pelo nome das personagens heroínas, Kazuko e Kazue,

${ }^{18} \mathrm{Em}$ Jardim das Cerejeiras, o fio narrativo conta a história de um cerejal pertencente a uma família de aristocratas em decadência e que está prestes a ser vendido. As personagens fazem de tudo para salvá-lo, e cada uma delas vê naquele pomar um valor sentimental, cultural ou social. O cerejal acaba sendo vendido num leilão a Lopakhin, filho de antigos servos da família, que havia se tornado um próspero burguês. (TCHEKHOV, 1981. p. xviii).

${ }^{19}$ Explicação original da foto: "Jardim do Pôr-do-Sol, antiga residência de Dazai. 'Na tarde fiz uma caminhada solitária e contemplei o jardim, num dia chuvoso, sob minha sombrinha'. (DAZAI, 1985, p. 98f, tradução nossa). Fotografia de Kimura Katsunori. 
respectivamente, e as duas personagens têm 29 anos. Essa similaridade deixa evidente a relação entre as duas obras. Em ambas as histórias, o pai está lá, dando suporte ao enredo, mas não como um personagem de caracterização. A mãe é uma parte essencial do enredo. Kazue acusa sua mãe de gostar mais do irmão do que dela. Kazuko também acusa a mãe de gostar mais do seu irmão. Nos dois romances, o irmão está ausente da ação. 


\section{Capítulo III}

\section{Análise da Estética do Espaço em Pôr-do-Sol}

Os lugares que conhecemos não pertencem somente ao mundo do espaço onde nós os mapeamos por nossa própria conveniência. Nenhum deles foi mais do que um infimo pedaço, suspenso entre impressões contíguas, que compôs nossa vida naquele momento; a lembrança de uma imagem particular não é nada mais que pesar para um momento particular; $e$ as casas, as estradas, as avenidas são efêmeras como os anos. (Marcel Proust)

\section{Análise do Espaço e do Tempo}

\subsection{O espaço em Pôr-do-Sol}

O conceito de espaço é muito amplo porque abrange praticamente todas as áreas de estudo, e muitos pensadores se dedicaram ao estudo do seu significado. Debruçar em cada um deles e citá-los aqui seria inviável e acarretaria o risco do reducionismo. As definições de espaço dão-se de acordo com a linha de estudo e até mesmo com o tempo em que estas foram desenvolvidas. Cada estudioso pretende flagrar um determinado ângulo do assunto, e em muitos casos existem convergências até desnecessárias, pois as definições dependem da lente ideológica do estudioso e do que, efetivamente, ele pretende provar.

Segundo Mikhail Bakhtin (2000):

A aptidão para ver o tempo, para ler o tempo no espaço, e, simultaneamente, para perceber o preenchimento do espaço como um todo em formação, como acontecimento, e não como um pano de fundo imutável ou como um dado preestabelecido. A aptidão para ler, em tudo - tanto na natureza quanto nos costumes do homem e até nas suas idéias (nos seus conceitos abstratos) -, os indícios da marcha do tempo. O tempo se revela acima de tudo na natureza: no movimento do sol e das estrelas, no canto do 
galo, nos indícios sensíveis e visuais das estações do ano. Tudo isso é relacionado com os momentos que the correspondem na vida do homem (com seus costumes, sua atividade, seu trabalho) e que constituem o tempo cíclico [...] (BAKHTIN, 2000, p. 243)

A diversidade de aspectos que o espaço, sob o ponto de vista narrativo, ocupa dentro do romance Pôr-do-Sol constitui um dos pontos chaves da narrativa. A descrição da metrópole Tóquio frente à recatada e provinciana Izu desdobra-se em amplas possibilidades de representação espacial. Contudo, vale ressaltar que o espaço nas narrativas recebe influências diretas de outras áreas, além da literária, como, por exemplo, da psicanálise, filosofia e sociologia. Carlos Reis (1994), em Dicionário de Narratologia, nos apresenta diversas noções de espaço. A idéia elementar do autor é que:

O espaço constitui uma das mais importantes categorias da narrativa, não só pelas articulações funcionais que estabelece com as restantes das categorias, mas também pelas incidências semânticas que 0 caracterizam. Entendido como domínio especifico da história, o espaço integra, em primeira instância, os componentes físicos que servem de cenário ao desenrolar da ação e à movimentação das personagens: cenários geográficos, interiores, decorações objetos, etc.; em segunda instância, o conceito de espaço pode ser entendido em sentido translato, abarcando então tanto atmosferas sociais (espaço social) como até psicológicas (espaço psicológico). 0 destaque de que se pode revestir o espaço atesta eloqüentemente na concepção de tipologias que compreendem o romance do espaço como uma das suas possibilidades, tomada efetiva naquele gênero narrativo, por força das suas dimensões e configuração estrutural. (REIS, 1994, p. 135)

O espaço pode, então, assumir uma variedade de aspectos, podendo ser o de uma metrópole ou o da privacidade de um recatado e pequeno vilarejo. Ao comparar um e outro, Reis (1994, p. 135) afirma que "[...] desdobra-se em amplas possibilidades de representação e descrição espacial [...]". Sendo assim, o espaço de uma narrativa abrange uma pluralidade de significados, visto que a noção espacial muda de acordo com alguns fatores estéticos e culturais. Para se ter uma idéia, o espaço no Romantismo recebia certo tratamento, e no Naturalismo ele era vinculado a outros fatores, portanto, abordado de outra maneira.

Para apresentar um conceito de espaço é preciso também considerar o lugar da produção da obra, o seu tempo, a origem do autor, a corrente literária e as 
tendências estéticas. A descrição de um espaço feita por William Faulkner nem de longe é semelhante às descrições de Guimarães Rosa, porque cada autor irá fornecer uma topografia do lugar conforme a sua experiência literária, territorial e humana.

Milton Hatoum (1993), em O Espaço no Romance Brasileiro, analisa os relatos de viagem e reconhece que, mesmo neste gênero, os autores escapam da visão puramente geográfica e caem na armadilha da autobiografia. Ou seja, ao falar do espaço exterior, o escritor — de qualquer corrente literária - deixa involuntariamente, às vezes, o seu Eu escapar das rédeas narrativas.

[...] as expedições dos naturalistas europeus não pretendiam apenas classificar a fauna e a flora do mundo natural e retificar sua geografia. Os viajantes desejavam também conhecer o Outro, já que para dominar e colonizar é necessário conhecer o território e o idioma de quem nele habita.

[...] No entanto convém lembrar que os relatos de viagem não apresentam uma construção ficcional. Narrada na primeira pessoa, a literatura dos viajantes às vezes se desvia de seu objeto de estudo e adquire um tom de confissão e autobiografia, pois o narrador evoca as suas origens (a pátria, a infância, a paisagem) enquanto viaja através do território que está observando, mas se existe na maioria destes relatos uma estreita cumplicidade entre literatura e informação científica, o que resulta de sua representação é antes um discurso pautado na objetividade científica, sobretudo na literatura dos viajantes do séc. XIX. (HATOUM, 1994, p. 38)

Zola foi a figura central do Naturalismo francês, cuja teoria proclamava que a psicologia e a ação humana são determinadas pela vida social. Com ele, o espaço recebeu uma atenção digna de nota. O autor influenciou praticamente toda a literatura universal. No Brasil temos o exemplo de Aluísio de Azevedo.

Outra maneira de focalizar o espaço é pela lente de Wolfgang Kayser (1958, p. 133-134), que diz existir três tipos de romance: romances de ação ou acontecimento, de personagem e de espaço. Como o enfoque aqui é sobre o espaço, e sendo a base desta pesquisa, será discorrido somente na tipologia de romance de espaço, aquele que se caracteriza, essencialmente, pelo destaque que se dá ao momento histórico e ao contexto social em que ocorre a narrativa. Talvez seja este tipo de romance um dos mais fluidos quanto à sua classificação.

No romance Pôr-do-Sol, apesar de referir ao período histórico da guerra, o autor não deixa transparecer em sua narrativa o contexto social degradante do 
conflito. A sua sutileza em não relatar a guerra diretamente é externado através dos personagens, especialmente nas lembranças da Kazuko ao dizer que os jika tabi foram as únicas lembranças daquele período triste da sua vida. Outro exemplo pode ser observado quando ela se refere a Tóquio como sendo "convulsiva."

Em determinadas narrativas o espaço é rarefeito e impreciso, enquanto em outras a espacialidade é densa e bem definida. Isso dependerá das tendências estéticas assumidas por cada escritor. René Wellek e Austin Warren (2003), ao analisarem esta questão, afirmam que alguns autores raramente descrevem interiores ou exteriores e que os ambientes, especialmente os interiores domésticos, podem ser vistos como expressões metonímicas e metafóricas da personagem. A casa de um homem é uma extensão dele. A casa não vive somente o dia-a-dia de uma história na narrativa de nossa história. Pelos sonhos, as diversas moradas de nossa vida se interpenetram e guardam os tesouros dos dias antigos. Kazuko, na nova casa, volta às lembranças das antigas moradias, e ela viaja até o país da sua infância imóvel, imóvel como o imemorial. Para ela, as lembranças do mundo exterior nunca terão a mesma tonalidade das lembranças da casa. Ao lembrar-se da sua antiga moradia, ela revive os devaneios do passado, que são, para ela, imperecíveis. No devaneio de Kazuko, a sua casa de Nishikata é um grande berço.

Embasado nas afirmações acima, o recurso literário de Dazai quanto ao uso da metáfora ganha espantoso relevo, porque a metáfora permite uma visão privilegiada devido ao fato de atingir, além das aparências, a essência das coisas. É um instrumento de visão do mundo que permite a recuperação de sensações distanciadas no tempo graças ao recurso da analogia.

Essa metáfora pode ser constatada no romance. Quando Kazuko refere-se à sua casa de Tóquio, ela não descreve os cômodos em detalhes, apenas descreve-a como sendo o local onde havia proteção e onde se sentia agasalhada no seio da casa. Essa casa de Tóquio está distante geograficamente, porém, na mente de Kazuko, está sempre presente como a metonímia do Japão que restou após a guerra. Em contrapartida, o interior da casa de Izu é sempre referido como um ambiente minúsculo que comporta somente os elementos familiares, que são apenas 
três pessoas, Naoji, Kazuko e a mãe. Essa casa está representada metaforicamente como o microcosmo no universo de Kazuko, e como a metonímia do Japão pósguerra, representada como o empobrecimento da nobreza e a reforma agrária ocorrida nesse período. Kazuko representa o empobrecimento do povo japonês mas ainda carrega o ideal de lutar pela reconstrução. A morte da mãe, o desaparecimento da classe aristocrática. Naoji é portador de fraqueza, de insegurança social e da própria consciência do fracasso que o impede de continuar a desvendar a vida.

Leyla Moisés (2000, p. 71) analisa o espaço na obra Em Busca do Tempo Perdido, de Marcel Proust, da seguinte forma:

Para ele, os lugares não existem como puros referentes; eles ganham existência graças a um forte investimento de afetos e de alusões culturais. Proust jamais descreve uma paisagem no sentido de reconstruir um verossímil espacial, como o faziam os escritores realistas. A descrição objetiva, em Busca, nunca vai além de uma frase. A seguinte já é divagação, projeção e transfiguração. (MOISÉS, 2000, p. 71)

O enfoque dado à decadência da classe aristocrática em Pôr-do-sol tem similaridade com a obra de Marcel Proust (1871-1922), Em Busca do Tempo Perdido. Nessa obra, Proust narra o declínio da nobreza, o mundo refinado dos Guermantes e a ascensão, nem sempre elegante, da burguesia rica que começa a freqüentar os salões outrora fechados, exclusivos e preconceituosos ao extremo. Mais do que isso, é uma obra que fala do tempo, da memória e da recuperação de ambos pelo narrador da história. Dazai também recorre ao passado para explicar o presente através de memórias da Kazuko, as leituras de diários de Naoji, que remetem a reminiscências da vida passada. O autor faz referência à atmosfera clássica do período Heian ao citar Diário de Sarashina, conhecida como Dama Sarashina.

O espaço proustiano prioriza a atmosfera afetiva que envolve lembranças, faltas e outros sentimentos que ele recupera através da memória. Por ser uma obra que enfatiza essa busca no tempo, grande parte dos espaços da obra são tratados com teor de subjetividade. A relação do narrador com o espaço é íntima, profunda e catalisadora. 
A perspectiva narrativa é outro elemento que influencia o espaço narrativo. Na visão de Carlos Reis (1994):

Uma das categorias da narrativa que mais decisivamente interfere na representação do espaço é a perspectiva narrativa. Quer quando o narrador onisciente prefere uma visão panorâmica, quer quando se limita a uma descrição exterior e rigorosamente objectual, quer, sobretudo, quando ativa a focalização interna de uma personagem, é óbvio que o espaço descrito se encontra fortemente condicionado na imagem que dele é facultada. (REIS, 1994, p. 137)

Para ilustrar esse argumento, o referido autor apresenta o exemplo da obra $A$ Cidade e as Serras, de Eça de Queirós. Nesse romance, o protagonista é um ser que vive em duas dimensões: a rural e a urbana. O narrador vive o típico conflito do homem do século XIX, que, com o surgimento da indústria, ficou dividido entre os valores habituais e a nova proposta de modernização dos costumes.

Segundo Antônio Cândido (2006):

[...] Observada no conjunto mesmo de maneira superficial, a obra de Eça de Queirós se apresenta, em grande parte, como diálogo entre campo e cidade, - ora predominando a nota urbana, ora fazendo-se ouvir mais forte a nota rural. Numa sociedade européia do século XIX, como a portuguesa, cidade deveria significar vida moderna, intercâmbios sociais intensos na participação na civilização capitalista do ocidente. Campo significaria tradicionalismo, economia agrária, sentido paternal nas relações entre classes. (CANDIDO, 2006, p. 39)

Além disso, existem inter-relações intrínsecas entre o homem e a natureza. Isso pode ser sentido mais intensamente pelos mais românticos. Para René Wellek e Austin Warren (2003, p. 299), "o ambiente pode ser a expressão de uma vontade humana. Se for um cenário natural, pode ser uma projeção da vontade [...]". Eles exemplificam isso dizendo: "[...] Um herói turbulento, tempestuoso, atira-se à tormenta. Um temperamento radiante procura a luz do Sol."

Todas essas definições ficam evidenciadas em Pôr-do-Sol por meio das interações de suas personagens com o meio. A dinâmica das duas cidades, a metrópole Tóquio e a rural e recatada Izu, está onipresente em Pôr-do-Sol, mas é evidenciada pelo desdobramento das personagens de destaque. O espaço fica 
caracterizado pelas ações dos personagens. Em Izu, o espaço da narrativa concentra-se em cenário mais reduzido, como a casa, o quintal, o aroma das floradas, etc. Ela representa o eixo microscópico em função do qual vão se definindo as condições históricas e sociais das personagens. O espaço urbano Tóquio é a antítese da vida suburbana em Izu. Contudo, entre as duas cidades há um fio condutor invisível que as une aos personagens.

O espaço social Tóquio configura-se, sobretudo, por ambientes que ilustram vícios e deformações da sociedade. O autor Dazai, ao retratar Tóquio, descreve-a de uma maneira sombria, cheia de lugares mal iluminados e esfumaçados de ambientes exíguos. Nesse ambiente habita o personagem decadente que vai sobrevivendo sob efeito da bebida em meio a desilusões e fracassos. $O$ ambiente urbano funciona também como tendo uma estreita conexão com as personagens para culminar no espaço psicológico.

Esse espaço é a causa determinante em evidenciar atmosferas densas e perturbadoras. Ele se projeta sobre o comportamento das personagens, normalmente conturbado, potencializado pela ação do tempo. Dazai, ao relatar o ambiente urbano em que a personagem habita, descreve-o como local de perdição, de vício. Como no caso de Uehara, que é descrito como sendo um escritor fracassado, decadente, libertino e bêbado. Ele ainda está predestinado a morrer de tuberculose, e, em razão da sua doença, até a sua fala demonstra desesperança em relação a tudo que ele diz (DAZAI, 1957, Apêndice B, p. 235): "É o crepúsculo da vida. O crepúsculo da arte. O crepúsculo da humanidade". Através dessas frases percebe-se que a ação do tempo sobre ele foi implacável, pois ele se acha em franca decadência. Kazuko, ao reencontrar o seu homem, com quem sonhara durante seis anos, fica estarrecida, tomada pelo choque. Ela não tem palavras românticas para descrever o estado deplorável de Uehara, e nada consegue a não ser comparar o seu amado ao caricaturesco macaco. Ao compará-lo a um animal, o sonho de Kazuko, em contato com a realidade, desmorona. Os anseios de outrora desaparecem instantaneamente. Essa ação sobre Uehara, em Pôr-do-Sol, vem descrita da seguinte forma: 
[...] Não era possível, ele estava diferente... seis anos! Ele se transformara numa pessoa completamente diferente. [...] Seis anos! Os cabelos soltos e desgrenhados do Sr. Uehara continuavam os mesmos de antigamente, mas estavam ralos e desbotados na tonalidade ruiva; o rosto amarelado e inchado; ao redor dos olhos havia irritações avermelhadas; ele estava banguela; ele movia e removia a boca continuamente, como se mascasse algo; parecia um velho macaco sentado no canto com as costas arqueadas. (DAZAI, 1957, Apêndice B, p. 230-231)

A razão da existência e do devaneio da Kazuko estava ali, como um ser grotesco conjugado a um ambiente degradante, num cubículo esfumaçado e abarrotado de beberrões. $\mathrm{O}$ ambiente tipificava a metrópole arrasada pela guerra e era habitado por seres desesperançados e descrentes do futuro. É comum os autores naturalistas usarem essas comparações com a natureza para reforçar uma imagem em seus personagens. Nesse aspecto, o Evolucionismo de Charles Darwin influenciou o Naturalismo. De acordo com Samira Campedelli (2001), nessa corrente literária,

o homem passa a ser visto especialmente sob o aspecto biofisiológico, tomado como ser animal, regido pelo instinto biológico, pelas mesmas leis que regem todos os animais. Dessa noção, decorre o gosto dos autores do Naturalismo pela zoomorfização, que consiste na aproximação, através de símiles, entre o homem e o animal, com o propósito de depreciar o humano. (CAMPEDELLI, 2001, p. 155)

Observando o exemplo de descrição de Uehara, pode-se notar que ocorre a aproximação do homem com um animal, enfatizando, por hipérbole negativa, a comparação a um ser inferior, como um macaco, para a decepção de Kazuko.

Podem-se constatar essas influências do meio e do tempo na caracterização dos personagens e dos aspectos narrativos no seguinte pensamento de Kazuko (DAZAI, 1957, Apêndice B, p. 230): "Eu estava em pé na entrada e, de repente, avistei Uehara. Logo que eu o vi, senti-me num sonho. Não era possível, ele estava diferente... seis anos! Ele se transformara numa pessoa completamente diferente. Era este, então, o meu arco-íris, o M.C., a razão da minha existência? Seis anos! [...]". A presença da figura decadente de Uehara leva a personagem ao estado de angústia e decepção.

A atmosfera é uma designação associada à idéia de espacialidade, sendo invariavelmente de caráter abstrato - de angústia, de alegria, de exaltação ou de 
violência -, e consiste em algo que envolve e penetra de maneira sutil as personagens. Mas não decorre necessariamente do espaço, embora surja com freqüência como emanação desse elemento, havendo casos em que ele se justifica exatamente pela atmosfera que evoca.

Para Antonio Dimas (1994), espaço e ambientação podem ser diferenciados:

\begin{abstract}
Por ambientação entenderíamos o conjunto de processos conhecidos ou possíveis destinados a provocar, na narrativa, a noção de um determinado ambiente. Para aferição do espaço levamos a nossa experiência do mundo; para ajuizar sobre a ambientação, onde transparecem os recursos expressivos do autor se impõe um certo conhecimento da arte narrativa. [...] o espaço é conotado e a ambientação é denotada. O primeiro contém dados da realidade que, numa instância posterior, podem alcançar uma dimensão simbólica [...] (DIMAS, 1994, p. 20)
\end{abstract}

A interpretação do espaço focalizado por Dazai Osamu na obra Pôr-do-Sol, a península de Izu, surge como metáfora da solidão e da beleza e como encorajamento para o renascimento. É um olhar descritivo sobre a terra japonesa. A apreciação da paisagem se torna pretexto para a construção poética, permitida por meio da personagem Kazuko. As descrições incorporam os registros dos hábitos da terra, dos costumes locais, da perenidade dos gestos. A topografia japonesa guarda uma história densa e milenar e a linguagem poética é uma maneira de perpetuar esse mundo imutável. As relações de homem e espaço não se baseiam na apropriação, mas numa cultura intocada que permite o reconhecimento mais original da sabedoria e dos hábitos do povo ligado aos ciclos da natureza.

Outro aspecto peculiar é que as únicas mudanças possibilitadas nesse espaço de permanência são justamente causadas pelo tempo. A linguagem poética expressa bem isso, pois enquanto a personagem - através da linguagem - intermedia 0 passado, o presente e o futuro, a natureza se mantém intocável, apenas à espera da ação do tempo sobre ela.

Izu aparece como uma região de forças adormecidas. Tais forças são despertadas através das imagens descritas pelo autor. A tarefa do escritor não é descrever pelo simples fato de descrever, mas para criar visões do que é ou do que pode vir a ser, ou seja, transformar a realidade do presente por meio da linguagem. 
No plano da linguagem, o poeta goza de autoridade, com o qual expressa a relação entre sujeito e espaço por meio de uma ação estética que vem também incorporar dados inter-humanos apreendidos do cotidiano, da história traçada pelos povos e de um saber transmitido há tempos. A protagonista do Pôr-do-So/vive quase isolada em Izu, ligada à natureza, que aparece como o único elemento que tem algum domínio sob aquela vida ilhada. Alheia às mudanças, Kazuko se sente marginalizada pelo urbano e sem identificação com ele, mesmo tendo dele feito parte um dia. Na nova situação, na península de Izu, a personagem busca novamente pertencer a algum lugar: aquele que possa abrigá-la e reconhecê-la como integrante. Banida de um espaço pela força das circunstâncias, ela tenta se entender novamente com outro lugar.

\subsection{0 tempo em Pôr-do-Sol}

Ao referir-se ao tempo e espaço no romance Pôr-do-Sol, é necessário definir primeiramente o que é o tempo. Segundo Arnold Hauser (2003, p. 954), o pensamento impressionista encontra expressão mais pura na filosofia de Bergson, sobretudo em sua interpretação do tempo - o vínculo que constitui o elemento vital do Impressionismo. A natureza ímpar do momento que nunca existiu antes e nunca se repetirá foi a experiência básica do século XIX, e todo romance naturalista, especialmente o de Flaubert, foi a descrição e análise dessa experiência. Mas a principal diferença entre a filosofia de Flaubert e a de Bergson era que Bergson ainda via o tempo como elemento de desintegração, por meio do qual a substância ideal da vida é destruída. A mudança em nossa concepção de tempo e, por conseguinte, em toda nossa experiência de realidade ocorreu passo a passo na pintura impressionista, depois na filosofia de Bergson e, finalmente, de modo mais explícito e significativo entre todos, na obra de Proust. 
O ponto de vista de Mikhail Bakhtin (1990) referente ao tempo e espaço, comparado com o de Hauser, difere significativamente. O primeiro trata o tempo mais objetivamente, como se pode observar pelas definições.

Nesse sentido, Bakhtin (1990) afirma que:

Em literatura, o processo de assimilação do tempo, do espaço, e do indivíduo histórico real que se revela neles tem fluído complexa e intermitentemente. [...]

A interligação fundamental das relações temporais e espaciais, artisticamente assimiladas na literatura, chamaremos cronotopo (que significa 'tempo-espaço') [...]. (BAKHTIN, 1990, p. 211)

Para Bakhtin (1990), esses dois elementos são indissociáveis. Ao analisar a obra de um só autor existem diversos cronotopos, que ao longo da história vão se entrelaçando como uma teia que se vai tecendo. Essa teia, no decorrer da narrativa, vai crescendo até o clímax, e no final da história os cronotopos caminham juntos. Os cronotopos não existem isoladamente no tempo e espaço reais que situam a obra.

Segundo Bakhtin (1990, p. 358), "[...] entre o mundo real representante e o mundo real representado na obra, passa uma fronteira rigorosa e intransponível. Isto nunca se pode esquecer; não se pode confundir [...]". Nesse sentido, percebe-se que muitas vezes o leitor confunde os tempos do autor-criador da obra com o do autorindivíduo. Entre a obra e o ouvinte-leitor está a mão do autor-criador do texto. Esse criador viveu um longo tempo atrás, porém o leitor o encontra no tempo e espaço dentro do texto.

O tempo urbano de Tóquio pode ser desdobrado em dois períodos: o tempo da protagonista Kazuko nas reminiscências do divórcio até o final da Segunda Guerra, e no reencontro com Uehara após o falecimento de sua mãe. E o do vilarejo Izu também em dois. Bem ou mal, Izu aparece como um espaço de poesia e tranqüilidade no primeiro tempo, momento em que a protagonista vai encontrando no campo alento para a sua inquietude e descoberta do seu verdadeiro Eu. $O$ segundo tempo é a revelação de que Naoji não morrera e que retornará para o lar. Esse fato se sucede quando a mãe de Kazuko revela um segredo a ela, dizendo: 
- Há muito tempo gostaria que me ouvisse, esperando uma ocasião em que nós nos encontrássemos com boa disposição. Até hoje esperei essa chance. De qualquer modo, não é uma conversa agradável, mas hoje posso falar sem rodeios, portanto, peço-lhe que tenha paciência e me ouça até o fim. Na verdade, Naoji está vivo. (DAZAI, 1957, Apêndice B, p. 185)

Com essa dinâmica temporal da narrativa, o espaço é afetado como se fosse uma cena teatral. Devido a uma disposição temporal de fatos históricos, da realidade e da ficção, o ambiente muda de tom para uma disposição espacial. A partir dessa revelação da mãe, o enredo romanesco atinge o seu ápice, como se mudasse toda a estrutura serena da narrativa. O comportamento psicológico da protagonista é abalado, trazendo à tona, através de flashback, todas as agruras passadas na ocasião da convivência com o seu desregrado irmão Naoji. Por parte da mãe, essa reação tão abrupta de Kazuko, recheada de revoltas e angústias, era inesperada. Para Kazuko, só de pensar em reviver um passado tão amargo desencadeia no seu íntimo uma relação de disputa pelo amor materno, e ela se sente excluída desse carinho, acusando a mãe de dedicar o seu amor mais ao irmão. No seu destempero de atitude, ela ameaça mudar-se para longe daquele lugar. Kazuko, para que a mãe sinta o quanto ela está magoada, faz um imenso drama, encenando estar profundamente ferida nos seus sentimentos, dizendo que ela dera a vida para que a mãe não se sentisse desemparada durante a ausência do filho e que a tinha acompanhado em sua transferência para uma nova moradia. Kazuko exterioriza toda a sua revolta e contrariedade com a nova situação.

Esse elemento fica claro na seguinte passagem escrita por Dazai (1957, Apêndice B, p. 189), no trecho do diário de Kazuko: "Ao recordar, vejo que foram esses os dias em que, pela última vez, brilhou o derradeiro lampejo da nossa felicidade. Desde então, com o regresso de Naoji, teve início o nosso verdadeiro inferno". Pelo tom das palavras proferidas por Kazuko em seu flashback, o leitor pode antever que um futuro dramático a espera, sabendo que a dura convivência com o problemático Naoji será inevitável, pois ele retornará a Izu viciado em entorpecentes. O tema desse fato gerador da mudança de cenário é a linguagem dramática expressada pelo romancista ao descrevê-lo. 
Somente a utilização do recurso lingüístico do romancista sugere um futuro negro para ambas as protagonistas, mãe e filha. A presença do funesto irmão de Kazuko já define o destino fatídico de todos os envolvidos na trama. Toda a imagem da arte literária é cronotópica, sua linguagem é como tesouro de imagens, em analogia a Lessing ${ }^{20}$, na afirmativa de Bakhtin (1990):

O princípio de cronotopia da imagem artístico-literária foi descoberto, pela
primeira vez, com toda clareza, por Lessing no seu Laocoonte. Ele
estabelece o caráter temporal dessa imagem. Tudo o que é estático-espacial
não deve ser descrito de modo estático, mas deve ser incluído na série
temporal dos acontecimentos representados da própria narrativa da
imagem. (BAKHTIN, 1990, p. 356)

Dazai possuía um profundo conhecimento da arte ocidental e do Cristianismo em suas particularidades. Isso fica claro na descrição que ele faz da morte da mãe de Kazuko. A imagem apresentada nesta cena é como o objeto de uma descrição estática, mas possui a força de uma narrativa dinâmica. Quando Kazuko (DAZAI, 1957, Apêndice B, p. 226) profere: "[...] mamãe aparentava estar mais encantadora do que em vida. Achei que ela se assemelhava a Maria de Pietà". Dazai conseguiu dar mobilidade à cena do referido falecimento da genitora. Ao aproximar um símbolo do catolicismo da morte da mãe de Kazuko, Dazai conseguiu a assimilação do tempo real, ou seja, ele conseguiu agregar uma realidade histórica à imagem poética da mãe, comparando-a com a Virgem Maria, remetendo, assim, à afirmação de Bakhtin sobre Lessing. O tempo futuro de Kazuko se dá, após o falecimento de sua mãe, quando ela vai até Tóquio reencontrar-se com Uehara. É como se findasse, nesse momento, o segundo período de Izu.

O tempo no espaço de Izu pode ser calculado de acordo com a medição dos acontecimentos temporais de Kazuko (DAZAI, 1957, Apêndice B, p. 181) quando ela diz: "No ano passado não houve nada. No ano retrasado não houve nada. $E$ no ano anterior ao retrasado, também nada". O ponto de intersecção das séries espaciais e

\footnotetext{
${ }^{20}$ Lessing, em Laocoonte, de 1766 (publicado no Brasil em 1996), define que cada modalidade das artes deveria adequar os objetos de sua imitação aos seus meios. Assim, caberia à literatura a imitação de ações, já as artes plásticas deveriam ter por objeto temas corpóreos, espaciais, e não a narrativa de histórias.

LESSING, G. E. Laocoonte ou Sobre as Fronteiras da Pintura e da Poesia. Tradução: Márcio Segligmann-Silva. São Paulo: Iluminuras, 1996.
} 
temporais do romance pode ser constatado através das cartas que Kazuko escreve para Uehara. Além desses motivos, ela ainda faz as reminiscências do passado temporal e espacial. Para embasar esse descarrilamento temporal dos fatos, lembremos Benedito Nunes (2002):

\footnotetext{
Enquanto o tempo físico se traduz com mensurações precisas, que se baseiam em instalações unitárias constantes, para o cômputo da duração, o psicológico se compõe de momentos imprecisos, que se aproximam ou tendem a fundir-se, o passado indistinto do presente, abrangendo, ao sabor de sentimentos e lembranças, 'intervalos heterogêneos incomparáveis' [...] (NUNES, 2002, p. 19)
}

O tempo físico é bem definido dentro do romance Pôr-do-Sol, mas não no sentido cronológico. Ele aparece, por exemplo, em forma de estações do ano, e no texto, o binômio tempo-espaço nunca é referido através do calendário gregoriano. É descrito em forma de floradas, como no caso de ameixeira que floresce no final do inverno no Japão, correspondente ao final de março e começo de abril. Há uma profusão de espécies florais, como peônias, rosas, crisântemos, etc.

Quando a personagem Kazuko quer referir-se ao tempo, recorre às suas reminiscências. Segundo Jean Pouillon (1974), o tempo presente determina o futuro. No caso de Naoji, pode-se dizer que com a leitura de seu diário no presente, o autor permite que o leitor anteveja o futuro da personagem. Por outro lado, Kazuko toma conhecimento da angústia de Naoji pela leitura do diário dele, no tempo presente dela. Através de flashbacks, Kazuko transporta para o presente as suas frustrações do passado, como o seu casamento fracassado e a perda do seu filho. Então, é possibilitado ao leitor entrar em sincronia com o tempo de Kazuko através do envolvimento com os fatos ocorridos na leitura de suas lembranças. Em uma mesma analogia, o tempo passado explica o presente.

No espaço de Izu, os personagens são os produtos do meio em conseqüência de um acontecimento social, como a decadência da família que teve como origem a guerra ocorrida no primeiro período na cidade de Tóquio. Jean Pouillon (1974, p. 22 
e 113) ao analisar o espaço, relaciona-o ora como uma contigência ${ }^{21}$ ora como fatalidade. Nesse sentido, o espaço de Izu, ao analisarmos o passado dos personagens, representaria uma fatalidade com forte influência do meio. No caso da mãe de Kazuko, a mudança para Izu foi uma antecipação da fatalidade, assim sua saúde começou a declinar logo após a chegada, culminando em sua morte. No caso de Naoji, em Izu agrava-se o seu declínio psicológico, e ele se mostra totalmente fragilizado, conforme se nota na seguinte fala de Naoji (DAZAI, 1957, Apêndice B, p. 196): "[...] Prefiro morrer por conta própria". O aparecimento de Naoji em Izu foi uma contingência, pois ele já carregava um destino sombrio quando da sua residência em Tóquio. A contingência não impede o destino. A contingência permite, não obstante, que o tempo, muitas vezes, se tranforme em destino.

Naoji segue uma conduta linear, sempre rebelde, e a sua caracterização aproxima-se à de um anti-herói. As descrições a respeito de sua atitude aparecem no tempo passado em forma de diário e nas reminiscências de Kazuko. O leitor vê Naoji com os olhos do romancista e também pela ótica de Kazuko, mas o seu verdadeiro caráter é revelado através do diário, onde ele externa toda a sensiblidade poética e romântica ao descrever a sua amada. São raras as ocasiões em que Naoji aparece no tempo presente, havendo ênfase em seus defeitos, que parecem anular suas virtudes, ao passo que a mãe de Kazuko se sente insegura em enfrentar um novo desafio em Izu. Ela sabe que irá se defrontar com uma vida cheia de privações. Essa insegurança, segundo Bakhtin (1990, p. 354), é conhecida como cronotopo da "soleira", sempre metafórico e simbólico quando Kazuko (DAZAI, 1957) narra o seguinte:

Com uma voz embargada e fraca, e para o meu espanto, mamãe falou:

- Sabe? Kazuko vou a Izu, porque você está comigo, viu? É porque você está comigo!

Senti-me estremecer e, sem querer, perguntei:

- E se eu não estivesse?

De repente, mamãe caiu em prantos.

- Seria melhor morrer. Eu também queria morrer nesta casa em que seu pai morreu.

${ }^{21}$ A contingência não é a pura e simples posição acidental no espaço; é uma inserção de um determinado gênero no tempo, e esta inserção só parece paradoxal quando esquecemos que se trata precisamente de uma inserção no tempo, e não de uma projeção no espaço. A fatalidade é uma característica fundamental e inexplicável da temporalidade. 
Disse isso aos soluços e começou a chorar aos prantos. (DAZAI, 1957, Apêndice B, p. 172)

A insegurança da mãe se reflete nos seus atos. Ela está ciente do futuro que a espera na nova vida e que Izu irá mudar radicalmente a sua existência. Izu é similar ao cronotopo da "soleira". Ao atravessá-la, não haverá retorno, pois seu antigo lar em Tóquio fora destruído.

\subsection{O cronotopo em Pôr-do-Sol}

$\mathrm{Na}$ análise do conceito de cronotopo salienta-se que o tempo comunica seu fluxo através do espaço, ou mais precisamente das figuras que compõem esse espaço. Tudo que existe e ocupa um lugar no espaço sofre a ação do tempo. Sem a esfera espacial a temporalidade não encontraria formas de se materializar. Ela se materializa no universo que anuncia suas transformações, ou seja, qualquer dimensão espacial só pode ser alterada pelo tempo quando sujeito ou objeto se movem, como também todas as noções espaciais podem ser explicadas em função do tempo. Para Bakhtin (2000):

O tempo se revela acima de tudo na natureza: no movimento do sol e das estrelas, no canto do galo, nos indícios sensíveis e visuais das estações do ano. Tudo isso é relacionado com os momentos que lhe correspondem à vida do homem (com seus costumes, sua atividade, seu trabalho) que constituem o tempo cíclico. O crescimento das árvores e do rebanho, as idades do homem, todos eles indícios visíveis que se referem a períodos mais amplos. Por outro lado teremos os sinais visíveis, mais complexos, do tempo histórico propriamente dito, as marcas visíveis da atividade criadora do homem, as marcas impressas por sua mão e por seu espírito: cidades, ruas, casas, obras de arte e de técnica, estrutura social, etc. (BAKHTIN, 2000, p. 243).

O tempo em Pôr-do-Sol é determinado pela natureza no sentido cíclico, isso quer dizer que é definido pelas floradas e pelas estações do ano. $O$ tempo não segue a ordem cronológica dos acontecimentos. Ele é constituído de monólogos interiores 
da protagonista, é o entrecruzar de acontecimentos presentes e de reminiscências de acontecimentos passados. Esse entrecruzamento é apresentado de diversas maneiras. A evocação do passado pelo presente, onde a protagonista vai revelando a personalidade de outro personagem Naoji através dessas evocações. Analisando Goethe - mais especificamente a percepção do tempo em Goethe -, Bakhtin (2000) afirma que o escritor possuía extrema habilidade para reconhecer o tempo por intermédio do espaço e afirma:

\begin{abstract}
Uma forma de ver o tempo é olhando ao redor e percebendo a evolução, a formação e a história.[...]

Goethe tinha vista aguda para todos os indícios e sinais do tempo na natureza: determinava muito depressa, a olho, a idade de uma árvore, conhecia o tempo de crescimento de diversas espécies de árvores, sabia ver as épocas e as idades. Tinha a vista aguçadíssima para os indícios visíveis do tempo da vida humana (desde o tempo cotidiano de uma jornada do homem medido pelo sol e pela ordem das coisas até o tempo de uma vida humana inteira). (BAKHTIN, 2000, p. 249)
\end{abstract}

O que predomina na obra Pôr-do-Sol é a coexistência do passado e do presente. Além disso, é todo o passado que pesa sobre o presente. O passado forma um bloco na cabeça de Kazuko. Esse tempo passado não segue também uma ordem cronológica. O que predomina é de certa forma intemporal, somente alguns fatos a protagonista retira da temporalidade à medida em que ela quer se referir a exatos momentos no caso em que se lembra do Uehara, dizendo que fora há seis anos. 0 passado, para Kazuko, não é mais um passado temporal, que deixou de ser e que ela pode apenas lembrar. É algo presente, atual. À medida em que ela revive esse passado, ele deixa de ser pretérito, tornando-se presente, como uma coisa que subsiste e que corrói a sua alma. Jean Chevalier e Alain Gheerbrant (1999, p. 876) fornecem um sentido mais simbólico para o tempo, oferecendo algumas representações para o tempo cíclico - bastante usado em várias narrativas que utilizam como recurso estético este tipo de tempo, o que define a visão agostiniana do tempo, "imagem móvel da imóvel eternidade." Todo movimento toma forma circular a partir do momento em que se inscreve em uma curva evolutiva entre um começo e um fim e cai sob a possibilidade de uma medida que é senão a do tempo. 
A morte da mãe de Kazuko demonstra que o passado constitui a realidade presente, o passado se faz presente durante todo o tempo, a dimensão fundamental do tempo. No passado, a mãe foi o ícone da nobreza. Apesar da decadência dessa classe social, ela carrega esse título ainda no presente. A descrição da mãe dentro do romance como sendo a dama da aristocracia é simbolizada como a força propulsora que move os personagens Kazuko e Naoji. O falecimento da mãe não obedece ao tempo cronológico, apenas é citado como o entardecer de um outono.

Essa visão de tempo indicada por Jean Chevalier e Alain Gheerbrant aparece no capítulo O Espaço e o Tempo, de Bakhtin, em que este apresenta a tendência estética do tempo histórico:

É nele que se especificam os indícios e as categorias do tempo cíclico - o tempo natural, cotidiano e agrário do idílio. [...] o tema das "estações do ano", dos ciclos agrários, das idades do homem, atravessa todo o século XVIII e tem muita importância na produção poética. Este tema, aliás, o que é muito importante, não se restringe estritamente a uma temática, tem um valor estruturante e organizador. (BAKHTIN, 2000, p. 244)

Ainda sobre a integração tempo-espaço, Bakhtin (2000) usa o termo cronotopo, como se viu. Para ele, no cronotopo literário tem lugar a fusão dos conotados espaciais e temporais num todo dotado de sentido e concretude. $\mathrm{O}$ tempo que se faz denso e compacto torna-se artisticamente visível. O espaço intensifica-se, insinua-se no movimento do tempo, no entrecho da história.

O tempo e o espaço são elementos indissociáveis em um romance. Para se referir ao tempo no espaço específico do romance é necessário retroagir no tempo histórico. A história de Izu remonta a uma série temporal e espacial da história japonesa. Como define Bakhtin (1990):

O castelo está repleto de tempo, que por sinal é histórico no exato sentido da palavra, ou seja, o tempo do passado histórico. O castelo é o lugar onde vivem os senhores feudais (por conseguinte, também as figuras históricas do passado) as marcas dos séculos e das gerações estão depositadas sobre as armas, na galeria de retratos dos ancestrais. (BAKHTIN, 1990, p. 351)

O temporal e espacial podem ser representados por um castelo. Em Pôr-doSol pode-se ressaltar que Izu, na província de Shizuoka, é um espaço de extrema 
importância histórica para o Japão. No período Edo (1603-1868), Izu foi o principal portão de monitoramento de entrada e saída dos transeuntes que viajavam pela única ligação entre Edo (atual Tóquio) e Quioto (antiga capital japonesa), em uma via denominada Tôkaidô. Por ela dava-se a passagem de ancestrais de samurais, senhores feudais, servidores da corte, comerciantes e artesãos que pernoitavam na aldeia Izu.

A aldeia de Izu, em Pôr-do-Sol, é análoga à Roma de Goethe, onde, na visão de Bakhtin, coexistem dois tempos. Assim também, em Izu coexistem o passado e o presente. Um vilarejo bucólico, com casas de veraneio da antiga nobreza japonesa do período antes da guerra, possui os mesmos solos, as mesmas colinas, os mesmos rios, as mesmas ruas, e o povo conserva ainda os vestígios do antigo caráter. De acordo com Bakhtin (2000):

A realidade do tempo histórico no interior de um pequeno espaço em Roma, a coexistência visível de diversas épocas, fazem o contemplador sentir-se participante do grande conselho dos destinos universais. Roma é o grande cronotopo da história humana. [...]

A sincronia, a coexistência dos tempos num único ponto do espaço, revela para Goethe a 'plenitude do tempo' tal como ele a percebia durante seu período clássico. [...] (BAKHTIN, 2000, p. 260-261)

Continuando-se a analogia de Izu a Roma de Goethe, acentue-se que a historicidade clássica do tempo da aldeia está repleta de lembranças do passado, principalmente das ocorridas após a abertura dos portos para o Ocidente na Restauração Meiji (1868-1912). A intensidade histórica desse cronotopo imprime a trajetória de prosperidade das pessoas que habitavam esse importante eixo TóquioQuioto. É também da região de Hakone e Izu que se pode ter uma visão privilegiada do maior ícone do símbolo imagético do Japão, o Monte Fuji que também agrega valores do passado.

Em Pôr-do-Sol o tempo é sempre entrecortado entre uma lembrança de Kazuko e a apresentação do diário de Naoji. Segundo Bakhtin (1990):

[...] Eles (cronotopo) são os centros organizadores dos principais acontecimentos temáticos do romance. É no cronotopo que os nós do enredo são feitos e desfeitos. Pode-se dizer francamente que a eles pertence o significado principal gerador do enredo. (BAKHTIN, 1990, P. 355) 
Seguindo a definição de cronotopo de Bakhtin o tempo e espaço de Pôr-do-sol não seguem uma linealidade de fatos. A narrativa é interrompida com a inserção de diários e cartas que remetem ao passado. Eles são elementos reveladores dos sentimentos de Naoji que a protagonista Kazuko toma conhecimento ao ler esses instrumentos manuscritos.

O autor, ao se referir ao espaço Tóquio, recorre a flashbacks da protagonista Kazuko, em lembranças da infância, da casa, das relações com o pai e outros parentes numa época de prosperidade. Em uma dessas lembranças, Kazuko (DAZAI, 1957, Apêndice B, p. 181) diz: "Pensei que nossas vidas haviam terminado quando saímos da casa em Nishikata [...]", referindo-se à perda do poder aquisitivo e da nobreza ocorrida em Tóquio. Assim, o leitor fica ciente dos fatos vivenciados pela personagem, podendo compreender suas angústias e frustações, sucessos e derrotas.

Para Bakhtin (1990):

É natural que o tema do idílio destruído pode variar bastante. Essas diferenças são determinadas tanto por compreensão e julgamento diferentes do mundo idílico destruído, como também por julgamento diferente da força destruidora, ou seja, do novo mundo capitalista. (BAKHTIN, 1990, p. 340)

No caso de Pôr-do-Sol a principal causa do idílio destruido é a guerra que acarretou na desagregação familiar de todas as relações humanas de outrora como amor, família, amizade. Outra força destruidora do idílio está nas relações humanitárias de fundo patriarcal. Uma delas ocorre em Tóquio no momento do falecimento do patriarca da família. Em outro momento, a força destruidora do idílio está na relação conflituosa entre Kazuko e Naoji, desencadeada com a disputa pelo amor da mãe, principalmente nos momentos em que sua mãe superprotege Naoji e Kazuko se vê obrigada a vender seus bens para sustentar os vícios do irmão, que era irresponsável e levava uma vida perdulária. Existem várias passagens onde Kazuko apresenta esses flashbacks relacionados ao cronotopo do mundo idílico destruído, ou seja, Tóquio, como quando Kazuko (DAZAI, 1957, Apêndice B, p. 198) lembra: "Desde então, já se passaram seis anos. O vício de Naoji em entorpecentes foi o pivô 
para o meu divórcio. Não, não posso dizer desse modo". Uma outra passagem de reminiscências de Kazuko (DAZAI, 1957, Apêndice B, p. 199): "Era o entardecer de começo de inverno. O vento estava gelado. Dava a sensação de que vinha soprando do rio Sumida $[\ldots]^{\prime \prime}$.

Em outro aspecto, Izu representa um novo cronotopo em Pôr-do-Sol: o do espaço de exílio onde a família fora alojada, distante do universo familiar e da gigantesca metrópole. Essa metrópole que outrora foi o centro cultural e do convívio com a aristocracia e de aconchego familiar. Nessa nova localidade proviciana e bucólica, Izu, Kazuko e sua mãe buscam a reconstrução da família, agora com reduzido número, restando apenas a mãe e o irmão. Acostumadas a ter as regalias da grande cidade, elas se sentem deslocadas socialmente nesse novo espaço. $\mathrm{Na}$ afirmativa de Bakhtin (1990):

\footnotetext{
Os aspectos idílicos estão esporadicamente espalhados no romance familiar. Aqui sempre ocorre uma luta entre a 'estrangeirice' desumana nas relações com as pessoas e as relações humanitárias sobre um fundo ora patriarcal, ora abstratamente humanista. No vasto mundo gelado e estrangeiro estão espalhados recantos calorosos de humanidade e bondade. (BAKHTIN, 1990, p. 340)
}

Diante desse fato, ao analisar a obra, constata-se que existem humanidade e bondade por parte dos aldeãos de Izu nesse novo momento de suas vidas, que ficam caracterizados pela solidariedade prestada à sua família na cena do combate ao incêndio, cena esta que marca um novo ciclo de vida para Kazuko.

O tempo de Tóquio, para Kazuko, pode se caracterizar pela destruição das relações idílicas familiares e patriarcais do passado. Contudo, continuava sendo o local em que ela poderia vislumbrar um futuro melhor. A esperança de Kazuko estava depositada em Uehara, através de seus pedidos para que ele a engravidasse. Portanto, Tóquio representava a possibilidade da maternidade e de sua felicidade futura.

Segundo Bakhtin (1990), o homem positivo do mundo idílico torna-se cômico, lamentável e supérfluo, ou transforma-se num abutre egoísta. Naoji, ao contrário de 
Kazuko, se enquadra nesta figura cômica, lamentável e supérflua ao transformar-se em fingidor, quando Naoji (DAZAI, 1957) confessa:

Quando fingi precocidade, as pessoas comentaram que eu era precoce. Quando fingi ser indolente, as pessoas comentaram que eu era preguiçoso. Quando fingi não saber escrever romances, as pessoas comentaram que eu não sabia escrevê-los. Quando eu fingi ser mentiroso, as pessoas comentaram que eu era de fato. Quando eu fingi ter dinheiro, as pessoas comentaram que eu era rico. Quando fingi ser insensível, as pessoas comentaram que eu era um cara insensível. (DAZAI, 1957, Apêndice B, p. 196).

Por mais que Naoji se esforçasse para revelar o seu verdadeiro Eu, todos os homens não conseguiram acreditar nele. Para ser aceito na sociedade o personagem precisou fingir para agradar a todos. Na verdade, o seu círculo de amizades estava ciente da sua fraqueza e os amigos sabiam do seu fingimento.

No idílio há uma relação do tempo com o espaço. A vida está intimamente ligada a um lugar. No caso de Pôr-do-Sol, a unidade de lugar limita-se à casa urbana de Tóquio. Lá está o ancestral familiar, a parte imóvel da propriedade capitalista e pertencente às antigas tradições da nobreza. No romance, o espaço idílico foi destruído, os membros da família aristocrática foram expulsos para Izu, localidade pacata a 100 quilômetros de Tóquio. Nesse pequeno mundo provinciano de Izu, o círculo familiar vai se reduzindo. Já sem o pai, restam, inicialmente, Kazuko, a mãe e Naoji. Com a morte da mãe e o suicídio de Naoji, resta só Kazuko, porém com uma nova vida em seu ventre. O próprio mundo vai se reduzindo ao espaço de Izu.

Segundo Bakhtin (1990):

[...] o romance deve educar o homem para a vida numa sociedade burguesa. Esse processo de educação está ligado à ruptura de todos os velhos laços idílicos, à expatriação do indivíduo. Aqui (expatriação) o processo da reeducação pessoal se entrelaça com o processo de destruição e de reconstrução de toda a sociedade, ou seja, com o processo histórico. (BAKHTIN, 1990, p. 341)

O cronotopo idílico em Tóquio é um marco que separa os tempos real e o das lembranças de um passado abastado. O tempo no espaço de Izu marca o recomeço da vida da família falida. Os personagens fazem um imenso esforço para superar a 
tragédia da guerra, do "exílio" em Izu e da reconstrução da vida. Nesse sentido, a classificação temporal em Pôr-do-So/se divide em dois tempos antagônicos: o tempo no espaço de Tóquio e o tempo no espaço de Izu.

Espaço de Tóquio - há agitação, destruição, e lá está o barômetro da vida política onde são tomadas as grandes decisões. Em Pôr-do-Sol, os dois mundos antagônicos, Tóquio e Izu, estão onipresentes na narrativa. A cidade de Tóquio é descrita pelo autor como uma cidade cinzenta, em caos. Apesar de essas duas cidades ocuparem lugares opostos na narrativa, Kazuko e seu irmão mantêm um laço íntimo com Tóquio. Tóquio, para Kazuko, será o espaço para a materialização do seu sonho de ser mãe.

A casa de Tóquio permanece na memória de Kazuko como o espaço em que ela passou a sua infância. A casa de Nishikata em Tóquio - o seu quarto, o jardim - ainda permanece como se fosse o seu ninho. O tempo e espaço de Tóquio são como um local dinâmico. Em contrapartida, Izu é o local onde o tempo permanece na mesmice. Esse marasmo pode ser verificado pela observação da natureza pela protagonista, como a primavera, o verão, o outono e o inverno. Lembremos que Bakhtin observa em relação aos espaços menores:

\footnotetext{
Essa cidadezinha ${ }^{22}$ é o lugar do tempo cíclico dos costumes. Nela não há acontecimentos, há apenas 'o ordinário' que se repete. O tempo é privado do curso histórico, progressivo, ele se move por círculos estreitos: o círculo do dia, da semana, do mês, de toda a vida. Dia após dia se repetem os mais habituais atos, os mesmos temas de conversa, as mesmas palavras, etc. [...] É o tempo cíclico comum, ordinário e cotidiano. (BAKHTIN, 1990, p. 353)
}

A Izu pode ser comparada a cidadezinha citada pelo Bakhtin porque nela não há acontecimentos relevantes nem grandes sobressaltos como em Tóquio. A natureza pulsa no ritmo das estações. Nascimento, vida, e morte. Aqui, o tempo é viscoso e rasteja no espaço. Através da personagem Kazuko (DAZAI, 1957) o leitor pode sentir a monotonia e o descompasso da vida:

\footnotetext{
${ }^{22}$ Em Madame Bovary de Flaubert, o lugar da ação é uma cidadezinha provinciana.
} 
[...] mesmo estando a tricotar na varanda com mamãe, sentia-me estranhamente sufocada, com falta de ar. Por outro lado, eu me sentia mais confortável cavanda a terra da horta.

[...] Pensando bem, a guerra não tem nenhum sentido.

No ano passado não houve nada.

No ano retrasado não houve nada.

E no ano anterior ao retrasado, também não houve nada. (DAZAI, 1957, Apêndice B, p. 181)

O autor expressa, através de Kazuko, a morosidade da vida. Para ela, o tempo se arrasta num ritmo vagaroso, beirando o insuportável. Até a companhia da mãe torna-se tediosa. Até nas suas lembranças o tom de monotonia se repete. No ritmo da vida de Kazuko o autor deixa transparecer o niilismo em que a protagonista se envolveu ao lembrar-se da guerra sem sentido. É o retrato da vida miserável do povo do pós-guerra. Kazuko é aqui representada como um trabalhador rural calçado com tabis que luta diáriamente revolvendo as terras da horta.

\section{Análise dos Elementos Estéticos}

\subsection{A estética dos elementos simbólicos em Pôr-do-Sol}

A simbologia da cobra - O cronotopo das cobras

A cobra, no romance, está onipresente em toda a narrativa. Ela é o fio condutor do enredo. Ela desempenha a função de interagir com a personagem principal, Kazuko, manipulando o estado emocional da mesma. De acordo com Jean Chevallier e Alain Gheerbrant (1999, p. 815), Bachelard define a serpente, no plano humano, como um símbolo duplo da alma e da libido: "[...] é um dos mais importantes arquétipos da alma humana". A cobra é uma personagem tão importante quanto a personagem principal, carregando o significado simbólico que representa o inconsciente do ser humano. 
Para Chevallier e Gheerbrant (1999, p. 814-815), ela não apresenta um único arquétipo, mas um complexo de arquétipos ligado à noite fria, pegajosa e subterrânea das origens. Ela é enigmática, secreta. É impossível prever-lhe as decisões, que são tão súbitas quanto as suas metamorfoses. Rápida como o relâmpago, a serpente visível sempre surge de uma abertura escura, fenda ou rachadura, para cuspir a morte ou a vida antes de retornar ao invisível, ou então abandona os ímpetos masculinos para fazer-se feminina. Enrosca-se, beija, abraça, sufoca, engole, digere e dorme. Esta serpente fêmea é a invisível "serpenteprincípio", que mora tanto nas profundas camadas da consciência humana quanto nas da terra.

Segundo o dicionário de símbolos de Baird (2001),

\begin{abstract}
A cobra, segundo o folclore japonês, é vista como tendo o poder de se transformar em forma humana feminina. A lenda popular atribui o fato da transformação como sendo de características femininas, isso quer dizer, volúpia, dolo, inveja e ódio. Devido a tais características do réptil, existe a crença de que elas são capazes de prevenir uma jornada pacífica de suas almas para o céu. Histórias de transformações de humanas-serpentes geralmente envolvem fantasmas. (BAIRD, 2001, p. 163, tradução nossa)
\end{abstract}

Os incidentes envolvendo as cobras são relatados pela ótica de Kazuko com certa perturbação, e até insanidade, ao visualizar o animal como portador de mau agouro. Ela associa-as como sendo as causadoras de toda a sua angústia e inquietude, e julga que a maldição da cobra atingiu sua mãe pelo seu (de Kazuko) ato inconseqüente de queimar os ovos do réptil. Esse pesar por seu ato impensado persegue-a até o final da trama. $O$ ato de queimar os ovos fez com que a víbora se alojasse em seu peito, e Kazuko (DAZAI, 1957, Apêndice B, p. 227) toma como lema: "[...] sede prudentes como as serpentes e símplices como as pombas". Ela se apega a esse provérbio bíblico cristão a fim de dar a si coragem para continuar a sua própria vida.

Qualquer que seja o significado da cobra (morte ou renovação), ela representa uma imagem perturbadora que evoca uma estranha beleza onde quer que apareça na narrativa. O estado emocional que ela sugere é mais poderoso do que as próprias imagens. Caso o leitor siga o conceito de Kazuko em relação à 
aparição da cobra, ele poderá confundir o simbolismo da mesma, porque no decorrer da trama o leitor fica ciente de que a cobra tem significado simbólico e poético.

No inicio do enredo do romance, a cobra é tida como um elemento inofensivo pela ótica de Kazuko. Ela a vê como um animal que está presente nos funerais apenas para se despedir dos mortos. Consequentemente a cobra ainda não traz perturbações no inconsciente dela. Isso pode ser constatada na passagem da narrativa quando Kazuko relembra o episódio da aparição da serpente dez anos antes: "Todavia, a mim não me amedrontavam tanto. Nisso veio-me à mente que, como eu, as cobras também estavam tristes pelo passamento do papai e elas saíram das suas tocas a fim de se despedir do morto". (DAZAI, 1957, Apêndice B, p. 169). Mas, passados dez anos ela cometeu um ato impensado de queimar os ovos das cobras. Desde então a narrativa do romance carrega uma dramaticidade em razão da culpa pelo ato infantil praticado pela protagonista. Kazuko começa a sentir remorsos por ter destruído o embrião do réptil, e com isso ela transfere no seu inconsciente essa culpa, dizendo que a maldição tomou conta do seu corpo e do de sua mãe. Na mente de Kazuko a cobra não é mais um animal inofensivo, mas, passa a ser associada a maldições e mau presságio.

A presença da cobra fica evidenciada nas seguintes falas de Kazuko:

\footnotetext{
Ah, o rosto triste da mamãe tem semelhança com aquela cobra de agora há pouco. Há uma víbora que habita o meu peito e essa víbora será capaz, de um dia, matar a cobra mãe... não sei porque tive esse mau presságio. (DAZAI, 1957, Apêndice B, p. 170).

[...]

Mamãe finge estar animada e feliz, no entanto, dia após dia, ela vai enfraquecendo e meu peito hospeda uma serpente peçonhenta que engorda com o sacrifício dela, e, por mais que eu a contenha, ela vai engordando. [...]. (DAZAI, 1957, Apêndice B, p. 176)
}

Kazuko, ao ver que não poderia mais contar com a fonte de renda do seu tio, começa a se tornar uma mulher áspera e desiludida, e isso é expresso através da imagem da cobra: "[...] em meu peito hospeda uma serpente peçonhenta que engorda com o sacrifício dela". O mesmo questionamento é feito pela protagonista do romance Osan quando ela diz que em seu peito aloja-se uma serpente. As 
citações abaixo são do dramaturgo Chikamatsu Monzaemon, que criou a personagem original $^{23}$.

De acordo com Lyons (1985), o relacionamento de Kazuko com sua mãe é, da mesma forma, um tema central de Pôr-do-Sol. Sua ambivalência com respeito à mãe é uma combinação da necessidade infantil que ela chama de "amor" e do ressentimento para com ela pelo fato de a mãe sempre tê-la censurado por não ter tido um filho. Na cobra, Dazai encontrou uma imagem vívida para concretizar e enfatizar essas emoções. Ambas as imagens são usadas simbólica e concretamente. Kazuko acredita que a cobra peçonhenta foi aninhar-se em seu peito e atribui a culpa da morte do seu bebê recém-nascido a essa mesma cobra, acusando-a de ter devorado o seu filho e de que esse réptil maldoso, a cada dia que passava, ia tomando conta do seu lado bondoso, dando a Kazuko a sensação de que esse animal já estava incontrolável dentro do seu peito. Por extensão, a maldição da queima dos ovos teria passado para a mãe. Na sua mente, a cobra que se apossou do seu corpo a cada dia torna-se mais forte, sugando toda a força da mãe, que enfraquece rapidamente. Para Lyons (1985), o temor de Kazuko é constatado nessa passagem:

Desde que Kazuko queimara os ovos da serpente, a sua mãe começou a ter pavor de cobras, e ela (Kazuko) lembra de ter visto algumas delas sob circunstâncias misteriosas no dia em que seu pai faleceu. Ela lembra claramente de uma agourenta cobra acompanhando a morte do seu pai (ela tinha dezenove anos na ocasião). Agora ela é atormentada pelo pensamento de que, inconscientemente, ela tenha estendido a maldição para a sua mãe. (LYONS, 1985, p. 166-168, tradução nossa)

Segundo Kayser (1958, p. 85), na análise de uma obra literária pode-se fazer a diferenciação entre motivos centrais e motivos subordinados. O motivo central dentro do enredo de Pôr-do-Sol foi a mudança de espaço de Tóquio para Izu, ocasionado pela guerra e conseqüentemente pela queda da aristocracia. Os motivos subordinados seriam a queima de ovos de cobra pela Kazuko, que desencadeia a ação da culpa, remorso e angústia, e o regresso de Naoji, irmão de Kazuko, aquele que se julgava morto.

${ }^{23}$ Osan é a personagem da peça Shinjû ten no Amijima, do teatro de bonecos Bunraku, cujo marido comete suicídio com uma cortesã. (KEENE, 1961, p. 387-425) 
Kayser (1958) chama a atenção ainda para o aparecimento recorrente de um determinado objeto em lugar significativo: a cobra como o objeto central e norteador de todas as emoções envolvidas nas duas personagens femininas da narrativa. Elas detêm o mesmo temor concernente à víbora, o que traz sensações de arrepio e nojo ao se defrontarem com esse réptil. Em Pôr-do-Sol encontramos o aparecimento da cobra em diversas ocasiões junto ao quintal:

[...] desde a morte de papai, na casa de Nishikata, mamãe começou a temer as cobras. Um pouco antes do seu falecimento, mamãe viu caído em sua cabeceira algo que pensou ser um cordão preto e foi pegá-lo, mas era uma cobra. [...]

Entretanto, ao entardecer do dia do falecimento do papai, eu havia realmente visto cobras em todas as árvores próximas ao lago [...]. Em todas as plantas, sem exceção, havia cobras enroladas por todo lado. [...] (DAZAI, 1957, Apêndice B, p. 169)

Desde o episódio dos ovos, a cobra não é vista por Kazuko como um animal que transmite benevolência, ao contrário, ela aparece como um animal repulsivo, mau agourento e que impele certo temor. Até o capítulo cinco do livro, as descrições das cobras são constantes, salientando o aparecimento como se fosse um mau presságio. No final do mesmo capítulo, após a morte da mãe, a cobra deixa de ser descrita na trama. É como se a maldição do réptil que insidia sobre Kazuko tivesse terminado com a morte de sua mãe. Aqui vale lembrar, como descrito por Baird (2001, p. 163), que as cobras garantem "[...] uma jornada pacífica de suas almas para o céu". Aqui se reconhece nitidamente a sua função de ligação. São meios técnicos da construção e composição. A repetição do ato é motivo condutor da ação, e no desenrolar da história a cobra realiza a coesão de todo o enredo. A cobra compõe o pano de fundo, como para integrar as personagens Kazuko e sua mãe. Além de dar coesão, a cobra atua como um fio condutor de dramaticidade e tensão dentro da trama. 
A flor é um dos elementos que muito saltam aos olhos do leitor na obra Pôrdo-Sol, principalmente a peônia, a ameixeira e o crisântemo. Há uma coerência estética no uso desse elemento por Dazai, porque a flor é a inspiração da maioria dos poetas românticos para externar seus sentimentos mais íntimos. Esse interesse pela botânica está presente na literatura clássica japonesa. Para Baird (2001, p. 18), símbolos metafóricos envolvendo plantas e animais nativos foram empregados na arte e cultura do Japão desde os períodos Nara (710-794) e Heian (794-1185). Nesses períodos, os poetas recorriam às plantas a fim de simbolizar a emanação de angústia interior e descrever as emoções das condições humanas em geral. Exemplo de planta influindo no sentimento amoroso é descrito naquele período com a planta amareleja que crescia nos arredores de uma casa decrépita, representando simbolicamente a perda do parceiro amado de uma mulher, enquanto que os campos gramados eram associados à solidão e desolação de outono. $O$ outono é a estação do ano que muitos japoneses associam intimamente à tristeza.

Na época da antologia poética Man'yôshû (século VIII), a flor teve o poder de verbalizar as sensações percebidas pelos poetas quando do contato com a matéria poética. Um dos poetas e nobre desse período chamado Okura catalogou as flores que floresciam nos campos outonais citadas em seu poema ( $\left.n^{\circ} 645-6\right)$. As espécies florais eram: susuki (Miscanthus sinensis, chamado de obana); kuzu (Pueraria thunbergiana); Patrinia scabiosaefolia; cânhamo agrimonia (Eupatorium japonicum); e ipoméia. São citadas também pelo poeta Okura as lespedezas com flores púrpuras que cresciam em densas moitas.

As flores de pessegueiro foram negligenciadas pelos poetas do período Manyô. Eles preferiam as flores de cerejeiras, que floresciam em grandes profusões, e as pequenas violetas, que exalavam doce fragrância e certamente atraíam a atenção dos olhos dos poetas e cativavam os seus corações. Havia também a florescente camélia, simbolizando o prolongamento dos dias primaveris. Esse arbusto rastejante ainda é abundante na planície de Kasuga, assim como a azaléia selvagem, que se associava alegremente a outras flores primaveris, como as glicínias. No verão florescia a kakitsubata, espécie de íris, a qual era citada freqüentemente em poemas 
de amor devido à sua forma e cor, além de emanar uma fragrância doce que sugeria beleza feminina.

O salgueiro verde da primavera era admirado por pertencer ao mesmo grupo de flores. Havia plantas menos pomposas, como bambus e juncos, que atraíam a atenção dos poetas de Man'yôshû. Os pinheiros ocupavam um lugar de honra devido às suas características masculinas e de longevidade, além da nobreza das suas hastes robustas, ou porque produziam sons claros de sussurros provocados pelo vento ao soprar entre os seus galhos.

Como pode ser visto, desde os tempos primórdios a flor é motivo poético, cantado universalmente pelos poetas como símbolo para enaltecer a beleza feminina e relacioná-la ao amor. As flores guardam uma simbologia particular dependendo da obra em que ela é inserida. Na obra Pôr-do-Sol, Dazai privilegia a superioridade da natureza enfatizando as flores como espaço poético. No contexto do enredo do romance, a flor representa um ciclo natural da evolução da natureza, é portadora do embrião do fruto e também promessa de vida, de perpetuação da natureza, que vai se transformando. Dazai, ao descrever a mãe da protagonista, traça um pararelo entre o ciclo vital e o caráter efêmero de uma flor. A mãe já cumpriu o seu ciclo vital na terra e, aos poucos, ela caminha para o fim. Como a flor, a beleza tem curta duração, sendo essa beleza abdicada em função do fruto. Do ponto de vista existencial, o fruto pode ser descrita como a perpetuação da espécie.

Dazai, ao agregar a figura da mãe aos motivos florais, deixa claro aos leitores que a sua intenção seria que Kazuko perpetuasse a nobreza. A morte da mãe representa para os seus filhos, e para os leitores, o desaparecimento do passado. $O$ nascimento do seu filho, mesmo sendo ele bastardo, será a continuação da aristocracia, como o desejo de Kazuko (DAZAI, 1957, Apêndice B, p. 247) ao dizer no final do romance: "[...] esta é a criança que Naoji secretamente teve com certa mulher". Ao analisar Kazuko, metaforicamente percebemos que ela, do ponto de vista do ciclo da vida em relação à sua mãe, seria o fruto amadurecido que no futuro dara à luz uma nova vida, dando continuidade ao ciclo vital da existência humana.

Segundo Jean Chevalier (1982), a disposição regular e irradiante das pétalas do crisântemo faz dessa flor um símbolo essencialmente solar, associado, portanto, 
às idéias de longevidade e até mesmo de imortalidade. Isso explica o motivo de ele ser o emblema da casa imperial japonesa. O crisântemo heráldico japonês tem dezesseis pétalas, o que sobrepõe à imagem solar a de uma rosa dos ventos, no centro da qual o Imperador rege e resume as direções do espaço.

Do Japão à China e ao Vietnã, muitas homofonias dão-lhe um papel de mediador entre o céu e Terra, associando o crisântemo não apenas às noções de longevidade e de imortalidade como também às de plenitude, de totalidade. Assim, ele passa a ser igualmente símbolo de perfeição e, portanto, de alegria para os olhos.

Tanto na Ásia como na Europa, o crisântemo é, por excelência, a flor outonal, e o outono é a estação da vida tranqüila após a realização dos trabalhos dos campos. O poeta So-kong Tu, da dinastia T'ang da China, faz do crisântemo o emblema da simplicidade, da espontaneidade natural e discreta dos taoístas. Dentre as espécies florais relatadas no romance, a flor de crisântemo é a que carrega a simbologia mais forte metafóricamente, quando Kazuko (DAZAI, 1957, Apêndice B, p. 213) diz "[...] concretizar os meus planos para que houvesse uma floração linda e triunfal como a de um crisântemo". O crisântemo é associado à aristocracia devido ao fato de ele ter sido utilizado pela primeira vez como símbolo da família imperial japonesa do século XIII. O interesse despertado entre japoneses pelo crisântemo como tema para poetas foi desenvolvido também durante o período Heian (794-1185). Naquela época, com a evolução da sensibilidade artística nativa influenciada pelas estações passageiras, a flor adquiriu seu lugar de destaque como o símbolo de outono, o que aguçou mais a sensibilidade artística dos poetas influenciados pela passagem das estações. Dazai outra vez recorre do estilo poético quando Kazuko (DAZAI, 1957, Apêndice B, p. 213) diz: "[...] depois, quando começassem a florescer os crisântemos e perdurasse o clima sereno e seco, com belos dias outonais, certamente a febre baixaria, e mamãe se fortaleceria [...]". Kazuko deposita toda a sua esperança nos dias outonais para a recuperação da sua mãe. Ela espera vê-la recomposta, tão bela e elegante como a flor de crisântemo. Nesse contexto, o crisântemo representa a metonímia da aristocracia no Japão, e a morte da mãe reflete a morte de uma cultura. 
Para Baird (2001, p. 74-75), os chineses atribuíam qualidades humanas ao crisântemo. Essa flor representa as virtudes de resistência e integridade. É também considerada símbolo de reclusão e era associada particularmente aos poetas e aos taoístas que tinham se retirado nas montanhas. Portanto, Kazuko seria a personificação de "resistência" e "persistência" ao enfrentar a sociedade e impor o seu ideal de querer ser mãe solteira, e também cabe aqui a comparação dela ao crisântemo, símbolo de reclusão. Kazuko, ao se mudar para Izu a fim de cuidar de sua mãe, é comparada à reclusão dos monges taoístas. Ela fez com que sua estada naquela aldeia fosse um momento de reflexão e de despertar para a dura realidade de viver na pobreza.

Já a peônia, flor que mais se evidencia devido à repetição na narrativa de Pôrdo-Sol, floresce no outono, que é a estação associada a um clima de tristeza e melancolia. O uso repetido de imagens simbólicas de peônia juntamente com o outono denota ao texto uma repetição de angústias e sofrimentos dos personagens. O autor, ao associar a flor de peônia ao outono, deixa transparecer sutilmente a atmosfera de tristeza prevalecente no Japão do período da guerra. A comparação da lã cor de peônia feita por Kazuko é como se fosse o seu lamento de desespero existencial. No momento em que ela combinou as cores, conseguiu dar conta de que a sua vida estava tão pálida quanto a peônia, o despertar de Kazuko e de milhões de japoneses de sua geração, que permaneceram impotentes para encarar o militarismo pós-guerra. O Japão que Kazuko vivenciava estava, como ela descreve, idênticas as cores cinzentas do céu e à pálida cor de lã.

[...] O céu cinzento e a lã pálida cor de peônia; ao combinar os dois, surpreende que ambos pareçam tão vívidos ao mesmo tempo [...] aquela cor pálida harmonizava com o céu de inverno, que anuncia a neve. Ela escolhera a lã especialmente e eu, tola, rejeitei-a [...] (DAZAI, 1957, Apêndice B, p. 190191)

Segundo Kayser (1958), o verdadeiro significado das imagens poéticas não reside na sua visualidade, mas sim no seu conteúdo emocional e sugestivo. A imagem da peônia pálida e embotada transmite ao leitor uma imagem da profunda tristeza de Kazuko com reforço da repetição da palavra pálida sugere um ambiente sem coloração. 
Apesar de a peônia estar relacionada simbolicamente a uma atmosfera melancólica, Baird (2001) tem outro conceito dessa flor, dizendo que os chineses consideravam a árvore de peônica (botânica: Paeonis suffruticosa) 'o rei das flores', e essa pomposa flor era vista como o símbolo de boa sorte, alta honraria. No entanto, eles associavam-na ao amor erótico. A peônia era uma referência à atividade sexual feminina.

Em algumas partes da narrativa as imagens visuais das flores transbordam as páginas. Dazai explora esse recurso lingüístico para sensibilizar o leitor, sendo a flor de ameixeira além da peônia a que mais salta aos olhos do leitor. Dentre as espécies florais, a primeira a florir é a ameixeira, que é descrita como sendo uma árvore que oferece abrigo e hospitalidade para o rouxinol. Ou, utilizando a figura de linguagem, as pétalas da ameixeira caem tremulando juntamente com os flocos de neve. Os pés da ameixeira têm emanado um apelo especial de frescor e de charme. Nos raros momentos de devaneio, Kazuko vê a beleza dessa flor característica (DAZAI, 1957):

\footnotetext{
Em fevereiro, o florescer das ameixeiras tingiu toda a aldeia com suas flores. Mesmo entrando em março, elas continuaram a exibir a sua beleza até o final do mês, em decorrência da calmaria do vento, que se estendia desde o mês anterior. De a manhã até o anoitecer, as flores das ameixeiras estavam esplêndidas, a ponto de arrancar suspiros. $E$ ao abrir a porta de vidro da varanda, o perfume da flor adentrava na sala. Em fins de março ao entardecer sempre soprava um vento, e enquanto preparava a mesa para o jantar pétalas de ameixeiras entravam pela janela e se molhavam dentro da tigela. (DAZAI, 1957, Apêndice B, p. 176).
}

A flor de ameixeira, em questões de simbologia, ocupa um lugar preponderante no romance. Ela é retratada em tom poético, fornecendo à protagonista meio para divagar e contemplar a criação da natureza. Mesmo numa passagem aparentemente ingênua baseada na observação de Kazuko, como no momento da descrição da queda das pétalas de ameixeira, o autor relata com refinamento e estética os elementos em questão. Dazai consegue transmitir para o leitor raros momentos de introspecção de Kazuko, ressaltando o seu lado sensível e observador da natureza. Nas tradições japonesas, a ameixeira, a canela, o crisântemo e o narciso formam um grupo conhecido como "Os Quatro Aristocratas." A junção desses quatro elementos simboliza a nobreza. 
A flor de ameixeira como um dos símbolos da cultura japonesa remonta a séculos atrás:

\begin{abstract}
A ameixeira (ume) provavelmente foi introduzida da China no período Nara (712-793), inicialmente a flor era freqüentemente mencionada na poesia japonesa e era famosa por seu perfume doce, com delicadas flores, e tem como característica florescer no final de inverno. Entretanto, no período Heian (794-1186) a preocupação com a transitoriedade da vida [...] a flor de ameixeira foi se esvaindo de significado poético. Mas outra flor com a mesma duração de transitoriedade entrou em cena: a flor de cerejeira e as folhas de bordo (Momiji). A flor de cerejeira também é associada os outros símbolos de longevidade, como o pinheiro e o bambu, e ao taoísmo chinês, geralmente conhecido como vida imortal. Há um simbolismo sexual atribuído às flores de ameixeiras, especialmente com referência à perda de virgindade de uma mulher. (BAIRD, 2001, p. 64, tradução nossa)
\end{abstract}

As flores de ameixeiras eram associadas aos poetas da aristocracia do período Nara (712-793). O refinamento e o gosto eclético desses poetas da nobreza pela flor de ameixeira podem ser observados através da poesia amorosa escrita por esses poetas a fim de enaltercer a beleza dessa espécie. A exaltação da flor de ameixeira é de autoria do nobre Yamabe Akahito (volume 8, 1426), compilado na literatura clássica japonesa Man'yôshû.

\author{
O florescer das ameixeiras \\ Queria poder mostrá-lo ao meu amado \\ Agora não é possível ser contemplado \\ Por culpa \\ Da neve que cai (MIYATA, 2000, p. 154)
}

Em Pôr-do-Sol, a flor de ameixeira aparece conjugada com a imagem de Kazuko denotando o simbolismo sexual atribuído à mesma. Portanto, quando ela observa as referidas flores, no fundo simboliza a sua vontade de querer ficar junto ao seu amado Uehara. A Kazuko, apesar do embrutecimento do seu Eu interior ocasionado pela decadência de sua família e da dura realidade de empobrecimento e de seu exílio, restava ainda, no seu íntimo, o lirismo e romantismo. Ela era ainda capaz de se emocionar e sensibilizar diante das obras da natureza. Isso fica claro quando Kazuko (DAZAI, 1957, Apêndice B, p. 176) diz: "[...] as flores das ameixeiras estavam esplêndidas, a ponto de arrancar suspiros". Em contrapartida, a flor de peônia denota a sensação de tristeza e obscuridade da alma da protagonista. Kazuko 
(DAZAI, 1957, Apêndice B, p. 190) narra: "[...] O céu cinzento e lã pálida cor de peônia $[. .$.$] cor pálida harmonizava com o céu de inverno que anuncia a neve [. . .]^{\prime \prime}$. Ela associa o outono à tristeza representada simbolicamente pela cor da flor de peônia.

De acordo com Betina Cunha (2000), ao aproximar a vida da flor, por um processo de superposição, o poeta instaura um novo mundo articulado por elementos sensisitivos, gravitando em torno de um núcleo essencial, a própria imagem vida-flor. Esses elementos: forma, cor, aroma, caracterizam o conjunto dinâmico e harmônico que a flor representa e, ao mesmo tempo, despertam no homem que a percebe emoções e sentimentos inusitados. Inusitados, mas relevantes para uma compreensão mais aprofundada, fundamental, dos valores e lições que a Natureza deixa entrever.

Aqui, é bom lembrar que, em decorrência dessa dupla efemeridade instaurada na vida da flor e de Dazai, o importante passa a ser a qualidade e a intensidade das emoções percebidas a cada momento de integração com a natureza transformante. Cada detalhe, cada nuance será, sem dúvida, um acréscimo de sentido e emoção poética que alegram o autor. Eternizando o essencial e preterindo o superficial, o material redimensiona o espaço do autor e valoriza a sua experiência vital.

Ao se considerar o efêmero ciclo vital da flor, compreender-se-á a extensão do milagre da natureza. A efemeridade da flor lembra também a efemeridade histórica da vida de Dazai, sempre ameaçado pela tuberculose implacável, a sua vida sendo abreviada no auge da carreira, sua opção pelo suicídio. Esse auge pode ser comparado ao auge do desabrochar das flores. A repetição das espécies florais reforça a narrativa na passagem em que Kazuko nutre uma ponta de esperança ao falar de crisântemos:

Depois, quando começassem a florescer os crisântemos e perdurasse o clima sereno e seco com belos dias outonais, certamente a febre baixaria, e mamãe se fortaleceria. [...] e concretizar os meus planos para que houvesse uma floração linda e triunfal como a de um crisântemo. (DAZAI, 1957, Apêndice B, p. 213) 
No decorrer da história, a metáfora é uma constante, principalmente a da cobra, a do outono e a do crepúsculo. Segundo Kayser (1958), a metáfora é um dos meios mais eficazes para a ampliação do âmbito de significado e para pôr em movimento aquele que entra nela. Portanto, a simples verificação de que estamos na presença de uma metáfora diz-se muito pouco. A interpretação estilística tem de analisar para onde é que o escritor nos quer conduzir através da metáfora e que funções ela exerce em cada caso, e tem ainda de estudar a conexão.

Evidencia-se isso na seguinte fala de Uehara:

- Não adianta. Tudo o que escrevo agora é estúpido e me parece bobagem, só me entristece. É o crepúsculo da vida. O crepúsculo da arte. $\mathrm{O}$ crepúsculo da humanidade. (DAZAI, 1957, Apêndice B, p. 235)

São palavras que podem ser tomadas como a metáfora do decadentismo, do niilismo e da tristeza da vida medíocre de Dazai o escritor, tomado pela tuberculose. O crepúsculo da humanidade é o Pôr-do-So/ do Império Japonês com a rendição da guerra, é a desesperança refletida no personagem Uehara. Os três personagens da trama de Pôr-do-Sol - Uehara, Naoji e Kazuko - são as transmutações da vida de Dazai. Naoji é o Dazai na juventude, Kazuko é o Dazai intermediário e Uehara é o Dazai decadente.

\subsection{A estética do espaço pictórico e poético em Pôr-do-Sol}

Pode-se dizer que a estética do espaço no romance Pôr-do-Sol possui heranças do Naturalismo: o homem condicionado ao meio em que vive, subjulgado pelo fator da hereditariedade, a presença de personagens patológicas, ambientes degradantes, questões de adultério, problemas ligado ao sexo. Esses elementos, em contraste com a natureza de Izu e o ambiente degradante de Tóquio, exemplificam bem a atmosfera retratada por Dazai Osamu, buscando apresentá-la da forma mais fiel possível ao leitor. 
Do princípio do romance até a morte da mãe da protagonista, a história está repleta de descrições detalhadas da botânica, principalmente das espécies florais. 0 leitor é induzido a devaneios provocados pela utilização de estilo de linguagem do autor, detendo-se em minúcias das descrições de estações de ano. A natureza salta aos olhos do leitor. Lembremos que, referindo-se a Jean Jacques Rousseau, Mikhail Bakhtin (2000) destacou:

A imaginação criadora de Jean Jacques Rousseau do século XVIII é cronotrópica. Foi ele que descobriu para a obra literária (precisamente para o romance) um cronotopo específico e importante: a natureza [...] Rousseau percebe com profundidade o tempo na natureza; nele as estações do ano estão em estreita interpenetração com o tempo da vida humana [...] (BAKHTIN, 2000, p. 257)

Assim como Bakhtin percebeu em Rousseau, para a análise da estética do espaço em Pôr-do-Sol, a pesquisa leva em consideração os elementos da natureza caracterizados pelos quatro elementos: o ar, a água, o fogo e a terra, baseados na teoria de Gaston Bachelard (1962, p. viii), como fontes de arquétipos do imaginário poético ${ }^{24}$.

O ar subdivide-se em céu e ar marítimo. A água toma forma de chuva, lágrimas, mar e oceanos. $\mathrm{O}$ fogo pode queimar ou ser a metáfora do fogo da paixão. A terra pode ser arada para o cultivo ou ser interpretada como as raízes do ser humano. A estética do espaço está intimamente ligada ao homem, que o transforma.

O espaço, assim como o ar, é infinito. É uma extensão imensurável da qual não se conhece o centro. Dilata-se em todos os sentidos. Dá uma noção de amplitude, força e abrangência que envolve o pensamento. $O$ ar induz a imaginação criadora a trabalhar com sonhos. Izu é como o espaço poético, de natureza

\footnotetext{
${ }^{24} \mathrm{Na}$ sua obra $A$ Formação do Espírito Científico, ciência e poesia aparecem como dois mundos distintos que deveriam ser mantidos separados para o beneficio da objetividade do conhecimento científico. Cada vez mais, porém, o imaginário poético atrai Bachelard, que passa a estudá-lo e a valorizá-lo como uma forma própria de apreensão e de recriação da realidade. A esse tema dedica uma série de obras: A Água e os Sonhos, 1912; O Ar e os Sonhos, 1943; A Terra e os Devaneios da Vontade, 1948; A Terra e os Devaneios do Repouso, 1948; e $A$ Psicanálise do Fogo, 1938. Através das obras de Bachelard pode-se constatar a premissa de que os quatro elementos da natureza, água, ar, terra e fogo, suscintam devaneios e imaginário poético naqueles que observam a criação da natureza.
} 
exuberante, que possibilita a interiorização e reflexão, onde os personagens se autoavaliam e verificam a situação degradante em que se encontram. Tóquio é como um espaço caótico, cosmopolita, que possibilita exteriorização e expansão, onde os personagens dão vazão aos seus desejos mais íntimos, seus vícios e libertinagens. Portanto, a estética do espaço, pictórico e poético, analisada em função dos elementos da natureza, além da atmosfera que envolve seus personagens, é um convite à participação do leitor na trama, pelo "olhar através da janela". Em outro aspecto, propicia uma melhor interpretação das emoções dos personagens e das mensagens sócio-culturais contidas na obra.

\section{A natureza do ar na estética do espaço - cronotopos do ar}

O ser é, no início, meio fera, meio floresta; mas quando o ar quer se tornar espírito, o homem surge. (VICTOR HUGO, séc. XVI). ${ }^{25}$

O ar, de acordo com Jean Chevalier e Alan Gheerbrant (1982), é um dos quatro elementos, como a terra, a água e o fogo - segundo as cosmogonias tradicionais. É, como o fogo, um elemento ativo, masculino, ao passo que a terra e a água são consideradas elementos passivos, femininos. Enquanto estes dois últimos símbolos são materializantes, o ar é um símbolo de espiritualização.

O ar também é infinito, matéria não mensurável. O ar, por seu caráter dinâmico e pelos devaneios que provoca na emoção poética, vem a ser substância onírica por excelência, e é através dele que o homem chega às alturas e reconhece seu valor, a dimensão de sua liberdade. É através dele que o espírito se solta das amarras racionais e recupera a linguagem dos sentidos. 0 ar induz a imaginação criadora a trabalhar com sonhos, o ar também é móvel e diáfano. Bakhtin (2000) salienta que:

[...] Os sentimentos externos, as emoções internas, as especulações e os conceitos abstratos se concentram em torno do olho que vê, como centro, como primeira e última instância. Tudo que é substancial pode e deve ser

${ }^{25}$ Le Satyre, In: La legend des siècles, sec. XVI. 
visível; tudo o que é invisível não é substancial. Todos sabem a importância que Goethe atribuía à cultura do olho e em que profundidade situava esta cultura. Em seu modo de compreender o olho e o visível, Goethe estava tão afastado do sensualismo rudmentar como do estetismo tacanho. O visível representava para ele não só a primeira, mas também a última instância, aquela em que o visível já está enriquecido e imbuído de toda a complexidade do sentido e do conhecimento. (BAKHTIN, 2000, p. 245)

Sua afirmação com relação à Goethe pode ser constatada na descrição pictórica do espaço da natureza no romance e, no nosso caso, na emoção de Kazuko ao contemplar o momento mágico produzido pela observação da topografia paisagística que ela se defronta ao chegar à aldeia de Izu. 0 devaneio em que ela se emerge provocada pela descrição minuciosa do panorama:

\section{- E depois, vejam a vista da sala.}

Eram mais ou menos três da tarde, e o sol de inverno batia no gramado do quintal [...] Sentada, assim, na sala, parecia que a altura do mar na linha do horizonte vinha tocar as pontas dos meus seios.

- Que vista agradável - disse mamãe num tom languido.

- Será por causa do ar? Os raios do sol diferem completamente dos de Tóquio. Eles parecem filtrados por seda. (DAZAI, 1957, Apêndice B, p. 173174)

Nesse contexto, quando Kazuko compara o ar de Tóquio, poluído e cheirando a destruição, com o de Izu, o ar da narrativa dá um tom poético ao cenário no imaginário do leitor. Dazai recorre à antítese para ressaltar a beleza e a pureza do ar que possibilita a visualização dos raios do Sol. Essa pureza denota uma natureza virgem, sem a interferência humana para poluir o ar da montanha de Izu. $\mathrm{O}$ ar de Tóquio é como um paralelo à atmosfera cinzenta devido à degradação da natureza pela mão do homem.

O autor traça um número grande de nuances no espaço que, em alguns momentos, subentende-se como o da melancolia. Kazuko (DAZAI, 1957, Apêndice B, p. 190) narra: "[...] O céu cinzento e lã pálida, cor de peônia [...] aquela cor pálida harmonizava com o céu de inverno que anuncia a neve [...]". Através dessa repetição, dá-se ênfase ao espaço pictórico, com o ar da melancolia de inverno.

Todos os comentários sobre a técnica da narrativa apóiam-se sobre uma simples observação, reforçada pela afirmação de Tzvetan Todorov (1971), que diz: 
Em toda obra existe uma tendência à repetição, que concerne à ação, aos pensamentos ou mesmo a detalhes da descrição. Uma destas formas seria, por exemplo, a antítese, contraste que pressupõe, para ser percebida, uma parte idêntica em cada um dos dois termos. (TODOROV, 1971, p. 216)

A palavra "outono" aparece inúmeras vezes no decorrer do romance, dando ao leitor a impressão de tristeza, de repetição e de monotonia na vida das protagonistas instaladas na remota aldeia de Izu. Pela descrição repetitiva do outono, a vida não se desenvolve na rapidez do tempo cíclico em Izu. Com a repetição passa-se a impressão ao leitor de que a vida das duas protagonistas espera somente o outono chegar para que se concretize a melhora da saúde da mãe, como pode ser constatado na ocasião em que Kazuko (DAZAI, 1957, Apêndice B, p. 213) diz: "[...] se perdurar o clima sereno e seco, com belos dias outonais, certamente a febre baixaria, e a mamãe se fortaleceria[...]". As frases se repetem e fazem alusão ao outono, ou servem como metáfora do tempo cíclico da natureza. Podemos observar isso nas seguintes frases de Kazuko:

"O céu cinzento e a lã pálida cor de peônia." (DAZAI, 1957, Apêndice B, p. 190)

"As estrelas brilhavam sob o céu outonal [...]." (DAZAI, 1957, Apêndice B, p. 220)

Em outros momentos, temos as seguintes referências metafóricas:

"[...] O quintal está totalmente forrado de ares de outono." (DAZAI, 1957, Apêndice B, p. 213)

"[...] manhã calma de outono. Jardim de outono, onde batem suaves raios solares [...]." (DAZAI, 1957, Apêndice B, p. 223)

O outono se faz presente na obra em diversos momentos e sob diversas nuances. Além do outono, a palavra "cobra" também se faz presente na obra como se incorporasse uma personagem, agindo no subconsciente da protagonista, trazendo aflições e inquietações a cada aparição dela (cobra). A conjunção da cobra e do outono na trama traz dramaticidade e melancolia à narrativa, e justamente a 
imagem pictórica atribuída ao ápice do outono ocorre no relato da morte da mãe de Kazuko:

Depois, passadas uma três horas, ela faleceu. Esse fato ocorreu num entardecer tranqüilo de outono, com a enfermeira a medir-lhe as pulsações, na presença de duas únicas pessoas consangüíneas: eu e Naoji. Nossa bela mãe, que fora a última dos nobres do Japão, havia falecido. (DAZAI, 1957, Apêndice B, p. 225, grifo nosso)

De acordo com Betina Cunha (2000, p. 45), "[...] o espaço vem a ser, portanto, um espelho a refletir o universo interior do poeta e refletirá ainda o universo no qual se move o outro $[\ldots]^{\prime \prime}$. A cena da morte da mãe é complementada com a seguinte narrativa de Kazuko (DAZAI, 1957, Apêndice B, p. 234 B): "[...] seu rosto estava liso como cera, e os lábios finos, ligeiramente retorcidos, pareciam externar um tênue sorriso; mamãe aparentava mais encantadora que em vida. Achei que ela se assemelhava a Maria de Pietà". O poder lingüístico de Dazai ao relatar o "entardecer tranqüilo de outono" faz com que o leitor se sinta envolvido pelo poder mágico da descrição poética da cena.

Ainda segundo Cunha (2000), o espaço,

[...] vem traduzir uma organização espiritualizada da visão, uma vez que o poeta pretende ver no meio externo, que percebe, a expressão do meio interior que vive emocionalmente. Assim se exprime o processo da imaginação criativa carregada das paixões da alma e do infinito de sensações mágicas que povoam o universo criador e sensitivo do homem. (CUNHA, 2000, p. 44)

A personagem Kazuko não se deixou abater pelo sentimento do seu meio interior, como a tristeza e o desespero. Ao contrário, viu na mãe o poder mágico do seu olhar metamorfoseando-a em Maria de Pietà. O uso da linguagem poética criou um cenário estético, fazendo com que o leitor compreendesse a amenização de Kazuko.

O inverno é outro tema recorrente na narrativa, ainda sob a análise do elemento ar. Ao recorrer dele, o autor não o faz no sentido de melancolia, mas o faz a fim de ilustrar o espaço, estética e poeticamente, narrado por Naoji em seu diário: 
Depois disso, ao entardecer de um dia de inverno, fiquei impressionado com o seu perfil [...]. Abri os olhos com o leve roçar do cobertor, e vi que o céu do entardecer invernal em Tóquio estava límpido e azul. Visualizei a esposa do pintor sentada calmamente junto à janela, com a filha no colo. Os contornos do seu perfil, delicado ressaltavam com fundo azul do céu pálido e longínquo, cujas silhuetas emergiam brilhantes como nas pinturas de perfis do tempo da Renascença. Ela colocou o cobertor carinhosamente, sem malícia, nem interesse. Não teria a palavra 'humanidade' readquirido seu sentido exato, quando utilizada numa ação como essa? E ela contemplava o distante céu, numa calma postura, idêntica à das pinturas. (DAZAI, 1957, Apêndice B, p. 243, grifo nosso).

A descrição do céu de Tóquio na narrativa de Naoji é poética e visa criar um espaço estético que mostre a metrópole como um lugar aprazível. Idêntica à visão de Kazuko com relação ao entartecer no inverno da provinciana Izu, porém, é discordante no sentido de comparar que o céu de Tóquio não é como o céu de Izu. Percebe-se que cada um revela seu estado de espírito na visão que possui do meio ambiente exterior e que o autor recorre à linguagem poética e estética para caracterizar o espaço de seus personagens, sob o mesmo tema, para sensibilizar o leitor.

A cena de Naoji caracteriza o símbolo da revelação de sua paixão em Pôr-doSol e é demonstrado, na forma de um amor platônico, na imagem figurada da mulher desejada, perfil delicado em contraste com o fundo azul do céu pálido e longínquo. $\mathrm{O}$ olhar da personagem transcende a realidade, colocando a amada no pedestal da imaginação criativa, como nas pinturas de perfis do tempo da renascença.

O mesmo ocorre com Kazuko ao referir-se ao seu amado Uehara:

Meu homem. Meu arco-íris. My Child. Malvado. Espertinho. Como se não houvesse outro nesta vida, tão belo, tão belo me pareceu seu rosto, e como se o meu amor por ele tivesse ressuscitado e se renovado no meu peito, beijei-Ihe, acariciando os seus cabelos. Triste, triste realização do amor. (DAZAI, 1957, Apêndice B, p. 239)

A estética do espaço do elemento ar, neste caso, é uma referência ao devaneio de Kazuko. O amor que sente por Uehara é compreendido como uma metáfora do arco-íris. Está subentendido como um amor passageiro como o arco-íris 
quando Kazuko (DAZAI, 1957, Apêndice B, p. 204) diz: "[...] o arco-íris que desponta no céu, após o entardecer chuvoso, tem existência efêmera e logo se desvanece, por outro lado, o arco-íris que brota no coração da gente tem existência duradoura". o autor recorre à antítese da efemeridade do arco-íris com a ação duradoura do amor. As simbologias concernentes ao espaço estético variam de acordo com o momento do acontecimento, criando um cenário pictórico. Portanto, nesse sentido, o elemento ar contribui para a compreensão das emoções vividas pelos personagens da trama.

\section{A natureza da água na estética do espaço - cronotopos das águas}

Desde os primórdios, as significações simbólicas da água podem reduzir-se a três temas dominantes: fonte de vida, meio de purificação e meio de regeneração. $A$ água é a origem da vida e o elemento de regeneração corporal e espiritual, 0 símbolo da fertilidade e da pureza. A água também é símbolo da dualidade. A água da chuva, por ser um dom do céu, é purificadora, é o símbolo universal de fertilidade e fecundidade. A água do mar, por ser salgada e agitada, significa o mal, a desordem. As águas amargas do oceano designam amargura do coração. Enfim, a água simboliza a vida, a água da vida, que se descobre nas trevas e que regenera. Foi dado por Gaston Bachelard (1884-1962) o tom poético sobre a água, quando ele escreveu sutis variações sobre as águas claras, as águas primaveris, as águas correntes, as águas amorosas, as águas profundas, dormentes, mortas, compostas, doces, violentas, a água mestra da linguagem, etc., que são outras tantas facetas desse símbolo cambiante.

O elemento água, para fins de análise da obra Pôr-do-Sol, desdobra-se em mar, chuva e lágrima. Segundo Chevalier e Gheerbrant (1982), a definição de mar é símbolo da dinâmica da vida. Tudo sai do mar e tudo retorna a ele. Lugar dos nascimentos, das transformações e dos renascimentos. Já Cunha (2000) complementa a definição do mar como sendo: 
intimida e põe em xeque a segurança emocional, o equilíbrio psicológico. (CUNHA, 2000, p. 112)

Águas em movimento, o mar simboliza um estado transitório para Kazuko entre as possibilidades ainda informes e as realidades configuradas, uma situação de ambivalência, que é a de incerteza, de dúvida, de indecisão, e que pode se concluir bem ou mal. $O$ mar é, ao mesmo tempo, a imagem da vida e a imagem da morte. $O$ mar que Kazuko contempla é um mar revolto cheio de mistérios. A personagem Kazuko, ao contemplar o mar, diz:

[...] pensei: o que houve ontem a noite é coisa do passado, não vou mais ficar lamentando. Permaneci um longo tempo atrás da cadeira da mamãe contemplando o mar matinal de Izu, através da vidraça. Senti que a minha respiração estava em sintonia com a dela. Serena. [...]. (DAZAI, 1957, Apêndice B, p. 179)

Aqui o autor traçou um paralelo com os sentimentos dela. A sua segurança emocional estava em pedaços. O seu estado psicológico estava em turbulência, como as águas agitadas do mar. Ela estava encurralada em uma situação de ambivalência. Kazuko não vislumbrava um futuro feliz para ela. De um lado, a mãe em estado de depressão, de outro, o irmão, agora viciado em bebidas e mergulhado em niilismo, esperando somente uma oportunidade para dar fim à sua vida.

Ainda segundo Cunha (2000).

Água, cujas significações simbólicas percorrem as mais diferentes e antigas tradições, oferece uma multiplicidade de representações possíveis e variáveis que vão desde a simbologia da fecundidade e fertilidade, purificação ritual, fonte de vida, até o plano rigoroso oposto, fonte de morte e destruição. (CUNHA, 2000, p. 81)

O mar que Kazuko observa pode também representar o curso da existência humana e as flutuações dos desejos e dos sentimentos. A região submarina se torna, dessa forma, símbolo do subconstiente. $O$ autor traça um pararelo com o sentimento da protagonista associando a água como símbolo das energias inconscientes, das virtudes da alma, das motivações secretas e desconhecidas. A água é o símbolo do espírito ainda inconsciente, encerra o conteúdo da alma. A água da chuva, quando não utilizada no sentido de purificação, é indicada pela narrativa de Kazuko assim: 
Chovia no dia seguinte, e fomos obrigados a fazer fila no sopé da montanha de Tachikawa, onde ouvimos o primeiro sermão do oficial.

[...]

Chovia na montanha [...] A chuva já havia transpassado a capa, encharcando a jaqueta e, por fim, molhou as minhas roupas íntimas.

Transportei terra no balaio o dia todo e, dentro de trem de retorno, foi impossível conter as lágrimas [...] (DAZAI, 1957, Apêndice B, p. 182)

A personagem estava encharcada. Essa água gelada, falando metaforicamente, exprime a estagnação, a ausência de calor na alma, a ausência do sentimento vivificante e criador que é o amor. A água representa a completa estagnação psíquica, a alma morta. A passagem acima apresenta a chuva simbolizando o oposto de purificação. Aqui, denota o desconforto da personagem e a angústia causada pelo frio da umidade, gerando nela a sensação de insegurança, de fragilidade, aumentando, assim, a sua sensibilidade e emotividade por estar servindo num conflito tão insensato como a guerra. A água da chuva, em consonância com a lágrima de Kazuko, simboliza a tristeza, o desabafo.

Em outro momento, Dazai recorre ao lirismo ao narrar os momentos de grande emotividade, transformando os momentos tristes em uma narração poética de Kazuko:

Corri em direção ao oficial a fim de devolver o seu livro e de lhe agradecer, porém as palavras não saíram. Fiquei calada olhando o seu rosto e, quando nossos olhares se cruzaram, lágrimas transbordaram. De repente, lágrimas brilharam também nos olhos do oficial. (DAZAI, 1957, Apêndice B, p. 184)

Dazai possibilita ao leitor captar a carga emotiva na imagem implícita. Mesmo nos momentos tão dramáticos, ele recorre à estética ao narrar um momento tão doloroso. Ele coloca poesia na narrativa de Kazuko, o derramamento de lágrima do oficial na forma "lágrimas brilharam", na intenção de sensibilizar o leitor e amenizar a dor da protagonista.

Em outro momento, Dazai relaciona o elemento água à inquietação, desordem e agitação de Kazuko pela fertilidade.

[...] Eu quero ter um filho seu. Filho de outrem não me interessa, haja o que houver. Por isso estou pedindo a sua opinião. Caso me compreenda, responda-me. Expresse-me todo o seu sentimento claramente. 
Parou de chover e começou a ventar. Agora, são três horas da tarde [...]. (DAZAI, 1957, Apêndice B, p. 207)

A passagem acima espelha a vontade de Kazuko de ser mãe. Ela sabe, porém, que está transgredindo o código moral, oferecendo-se como amante a um homem casado e com família. Cunha (2000) afirma a inquietação e desordem no ambiente relacionado com a chuva e vento dizendo:

Considerar a tempestade como fenômeno da natureza, pode-se imaginar uma chuva forte e violenta, acompanhada de ventos irrequietos que se movimentam desorganizadamente, provocando desordem e perturbação em todo o processo natural do ambiente. (CUNHA, 2000, p. 70-71)

Para Cunha, tal manifestação, de natureza física, se estendida ao campo da moral, pode traduzir uma desordem espiritual, vista por alguns como exemplo do poder e da cólera divina.

A chuva como associação para os momentos angustiantes na narrativa surge em momentos como este, descrito por Kazuko (DAZAI, 1974, p. 219): "[...] Sucederam-se dias chuvosos, quentes e úmidos. A febre da mamãe oscilava entre trinta e oito e trinta e nove graus todas as tardes". A chuva representa, na linguagem empregada por Dazai, a inquietação e angústia de Kazuko pela saúde de sua mãe. Ao usar o elemento água, Dazai apresenta ao leitor todas as inseguranças, incertezas e angústias que conturbam a paz do seu espírito.

\section{A natureza do fogo na estética do espaço - cronotopos do fogo}

O símbolo do fogo purificador e regenerador desenvolve-se tanto no Ocidente quanto no Oriente. A liturgia católica do fogo novo é celebrada na noite de Páscoa. A do Xintô coincide com a renovação do ano. $O$ fogo, na qualidade de elemento que queima e consome, é também símbolo de purificação e de regeneração.

O fogo na narrativa de Pôr-do-Sol norteia o enredo da história. Como na atitude impensada de Kazuko, que ao queimar os ovos da serpente dá início ao seu 
calvário. Os ovos de serpentes, no folclore japonês, segundo Baird (2001, p. 163, tradução nossa) justificam que "[...] é creditada a crença de que elas [as cobras] são capazes de prevenir uma jornada pacífica de suas almas para o céu [...]". A sua negligência, ao destruir os ovos do réptil, custou-lhe a inquietação de não ter a tal jornada pacífica de sua alma para o céu. Dentro de seu peito, cresce o mau presságio que tomou conta de seu subconsciente.

O fogo faz-se ainda presente na vida de Kazuko na passagem do incêndio da sua casa. Na narrativa, Kazuko relembra essa tragédia da seguinte forma:

Ao espiar casualmente, pela vidraça, ouvi o crepitar do fogo e reflexos vermelhos no vidro. Corri descalça para o postigo do banheiro, e vi o amontoado de lenha ao lado da fornalha, ardendo com espantoso ímpeto. (DAZAI, 1957, Apêndice B, p. 177)

O incêndio trouxe para Kazuko uma lição de sabedoria e responsabilidade pela vida dos outros e da sua. Kazuko, em conseqüência do incidente, foi capaz de conhecer a solidariedade e amizade dos aldeãos vizinhos e, acima de tudo, a compaixão humana. Kazuko (DAZAI, 1957, Apêndice B, p. 178) conhece a sua atual condição "[...] Eu estava descalça, de pijama. De repente, senti vergonha do meu próprio aspecto e, percebi que me encontrava em franca decadência". Dazai utiliza o fogo para apresentar a mudança ocorrida em Kazuko, que desperta para a humildade e conhece a solidariedade do ser humano.

Além do fogo no seu sentido literal, o autor recorre à simbologia da chama no seguinte trecho da narrativa de Kazuko (DAZAI, 1957, Apêndice B, p. 204): "[...] Desde muito tempo atrás, quando ocorre algo ruim, anseio muito ir voando ao seu encontro, devorada pelas chamas da paixão". A metáfora "chama do amor", na afirmação de Cunha (2000), é sinônimo de uma efetiva relação amorosa que representa a cumplicidade e a posse total de dois corpos. O leitor pode visualizar o calor de Kazuko se materializando em "ir voando ao seu encontro", que, na imaginação de Kazuko, seria a concretização do amor, a sua união com Uehara. Para Bachelard, o amor é a primeira hipótese científica para a reprodução objetiva do fogo, e antes de ser filho da madeira, o fogo é filho do homem. 0 método de fricção 
surge como o método natural, porque o homem chega a ele por sua própria natureza.

O incêndio, analisado pela ótica materialista, denota destruição, perdas e derrota. Mas na ótica da linguagem poética, dada pela análise dos elementos da natureza, Betina Cunha (2000) define que o fogo representa,

[...] - incêndio -, conseqüência cabal da temática do fogo, destaca-se, apresentando uma nova imagem, Aux souvenirs em loque de la véritè Lumière noire vieil incendie.

[Todas as lembranças em trapos da verdade Incêndio envelhecido já não queima]

que, paradoxalmente, se associa à negação do fogo. Na medida em que se pensa em 'lumière noire', imagina-se a própria ausência do fogo, ausência da luminosidade e clareza que, fatalmente, o acompanham. (CUNHA, 2000, p. 142)

$\mathrm{Na}$ análise da frase "todas as lembranças em trapos da verdade [...]" compreendemos o verdadeiro sentimento de Kazuko. Durante seis anos ela viveu no devaneio alimentado pelas lembranças de seu primeiro encontro com Uehara. Por todo esse período ela se distanciou da verdade criando uma verdade distante da imagem do seu amado daquela que a imaginação imprimiu em sua memória. 0 encontro dela com o Uehara de seis anos atrás continuava vívido na sua memória porque na verdade a lembrança não se refaz, a lembrança prossegue como um instante mágico até o momento em que o elemento sonhador se defronta com a realidade.

Ao avistar Uehara após seis anos, ocorre em Kazuko o desmoronamento de todo o seu devaneio, e, em questão de segundos, a magia daquela época se esvai. Isso é notado quando ela (DAZAI, 1957, Apêndice B, p. 231) diz, com certo desapontamento: "[...] parecia um velho macaco sentado no canto com as costas arqueadas". Para Kazuko, a confrontação da realidade foi mais cruel do que ela imaginava. Contudo, não se deixou abater pela visão imagética negativa de Uehara. Tinha sido o seu romantismo que havia gravado em sua memória a figura luminosa de Uehara. Como no verso "[...] incêndio envelhecido já não queima", o encontro de Uehara com Kazuko já não era o amor ardente de antes, o "fogo da paixão" já havia 
arrefecido, falando metaforicamente. Para Kazuko, o encontro com a figura decadente de Uehara é como se fosse o "incêndio envelhecido que já não queima". Com a constatação da realidade do Uehara decadente e doente, Kazuko torna-se manipuladora, e arquiteta o seu plano de ser mãe tomando Uehara como um objeto apenas de reprodução quando ela fala em My Comedian (Meu Farsante).

\section{A natureza da terra na estética do espaço - cronotopos da terra}

A terra, como a água, tem a força de germinar as plantas. Toda terra se torna, assim, símbolo do consciente, do desejo terrestre e de suas possibilidades de sublimação e de perversão. É a arena dos conflitos da consciência no ser humano. A terra em Pôr-do-Sol está simbolizada como um meio de Kazuko descarregar todas as suas tristezas e frustrações, quando ela afirma que até a companhia da mãe já estava insuportável e que preferia trabalhar na terra. Para Kazuko, a terra é um meio de sustento pelo fato dela cultivar a horta e extrair verduras frescas para manutenção da saúde das duas. A terra tornou-se um elemento importante para sua vida, pois Ihe transmite energia e vitalidade. Isso fica evidente quando Kazuko diz:

[...] Mamãe se preocupava muito com minha saúde, mas, ao contrário, eu me tornei mais forte e, quanto ao trabalho braçal, adquiri mais confiança. Trasformei-me numa mulher que não sofre mais com o trabalho duro da lavoura. (DAZAI, 1957, Apêndice B, p. 184)

Ao entrar em contato com a terra, Kazuko se torna uma parte da natureza, e o trabalho de lavoura não Ihe cansa mais. A terra, como as estações do ano, obedece ao ciclo da vida, o nascimento das plantas, a sobrevivência delas e também a morte do ser humano que volta à terra transformando-se em pó, que ajudará, com sua matéria, na função revitalizadora, que retoma a forma de terra, tornando-se elemento mineral. A cada dia que passa, a rudeza de Kazuko começa a se identificar mais com a terra bruta, similar à que ela ara no quintal da sua casa. Assim, ela se 
tornou fruto da harmonia entre o homem e a terra. A terra é mãe e sustenta toda a sociedade.

De acordo com Cunha (2000),

A terra, visível na sua superfície, guarda inúmeras lições de vida, sobrevivência e dignidade. Ela é abrigo seguro para as plantas se enraizarem. É a ancora na qual os homens fixam o seu destino e é, enfim, o alicerce sólido que firma o universo visível, fazendo dele um conjunto de princípios e imagens concretas. (CUNHA, 2000, p. 163)

Ao fixar o seu destino no espaço Izu, Kazuko conseguiu a comunhão com a natureza. Aflorou nela a sensibilidade da percepção do germinar das plantas, agora conseguia observar o florescer das ameixeiras e peônias e outras espécies florais. Aos poucos, Kazuko, com o contato direto com a terra, vai renovando a sua energia, porque a terra é dotada desse poder de revigorar os ânimos. O mesmo ocorre quando ela entra em contato com a terra, que ameniza a rigidez sofrida na guerra, expressa na seguinte narrativa da personagem:

As jika-tabi que calço agora para revolver a terra foram distribuídas pelo exército. Nunca havia calçado antes essa tal de jika-tabi. [...] Hoje, ao calçálas de novo, senti leveza, como se eu tivesse andando descalça, e pude constatar a alegria dos pássaros e animais ao entrar em contato com a terra sem os calçados. Senti uma felicidade imensa e tal alegria quase me doía 0 peito. (DAZAI, 1957, Apêndice B, p. 181)

Através do contato com a terra, Kazuko vai descobrindo as belezas da natureza. Sua sensibilidade ao observar um gesto tão óbvio dos animais, como pisar o chão, possibilita-lhe um novo olhar do mundo. O autor concebe um tom poético à estética do espaço, onde ela se situa, empregando o elemento terra como mola propulsora para esse despertar.

\subsection{A estética do espaço musical em Pôr-do-Sol-cronotopos da música}


A musicalidade existente dentro de Pôr-do-Sol aparentemente é tida, pelos críticos literários, como sendo uma improvisação de Dazai. Porém, Jinzai Kiyoshi em janeiro de 1948, organizou uma reunião com vários críticos literários, que concordaram com a possibilidade de haver musicalidade na obra Pôr-do-Sol. Isso fica evidente quando esses críticos, juntamente com Jinzai (1968, p. 105, tradução nossa) reafirmam: "[...] A vontade de Dazai era colocar Shayô em forma de música. Que a obra está estruturada solidamente na musicalidade é uma verdade, ou talvez seja um disfarce especial de improvisação [...]". Baseado em tais afirmações, eles consideram que Dazai a escreveu conscientemente, e foi genial ao fazê-la assim, com musicalidade.

Ao analisar as possibilidades, de intencionalidade e improvisação, pode-se considerar que Dazai, ao compor o espaço de Pôr-do-Sol com elementos estéticos, tinha em mente a cadência musical e o compasso ritmado. Analisando a obra de Dazai Osamu, Jinzai Kiyoshi (1968) diz que em Pôr-do-Sol existe musicalidade e lirismo. Ainda segundo Jinzai (1968), a musicalicalidade poderia estar relacionada com a obra clássica Quarteto em Corda em Dó Maior, de Mozart. De acordo com ele, o romance foi dividido em quatro movimentos, adaptados na forma de sonata. Juntamente com esses movimentos musicais existem temas que norteiam os movimentos musicais.

Primeiro movimento do Quarteto em Corda, de Mozart

O primeiro movimento se inicia com a apresentação da mãe, "a última das damas da aristocracia", ainda nobre e elegante. Descreve os seus gestos de tomar a sopa com postura refinada, comer com as mãos e até mesmo o ato de urinar atrás do arbusto, que quando realizadas pela mãe apresentam fina graciosidade. Pode-se 
dizer que o esse movimento está em forma de uma linda sonata ${ }^{26}$ e a velocidade de execução musical em allegrơ ${ }^{27}$. Essa cena seria a introdução.

O tema desse movimento se dá quando da mudança de Kazuko e sua mãe para a aldeia montanhosa de Izu. O ponto central é o momento em que acontece o incêndio no fundo da nova casa e os aldeões as ajudam, ocorrendo, assim, a integração delas ao espaço. O tema continua até o momento em que Kazuko tem lembranças da guerra, quando ocorreu o alistamento militar e Naoji foi para os Mares do Sul.

O primeiro movimento se encerra com o florescimento de uma rosa roxa em seu jardim. Nesse momento, ocorre um diálogo entre ela e sua mãe que diz que ela considera tais fatos corriqueiros como se fossem muito importantes. Kazuko (DAZAI, 1957, Apêndice B, p. 191) diz: "É que não tenho filhos". Com essa fala, Kazuko se apercebe de sua insatisfação e frustração perante a vida.

Segundo movimento do Quarteto em Corda, de Mozart

O segundo movimento é iniciado com o retorno de Naoji da guerra, quando Kazuko pega o antigo diário dele e lê em seu conteúdo o sofrimento de um viciado em entorpecentes. Kazuko faz uma retrospectiva da sua vida e lembra-se de acontecimentos de seis anos antes, quando procurou um amigo de Naoji, o Sr. Uehara, em Tóquio, para pedir-lhe ajuda. Uehara foi um antigo mestre de Naoji, um escritor fracassado, desregrado, com mulher e filho, que nas lembranças de Kazuko a remete ao passado onde ele rouba-Ihe um beijo. Kazuko, em suas reminiscências, traz à sua vida atual as cenas do divórcio do antigo marido e a morte de sua filha.

Esse movimento é caracterizado pelo envio de cartas de Kazuko para Uehara. Na primeira carta, Kazuko dirige-se a Uehara utilizando-se das enigmáticas iniciais "M.C.", que depois são decodificadas como "Meu Chekhov". Nessa carta está

\footnotetext{
${ }^{26}$ Peça de música instrumental, para conjunto ou solo, que classicamente se compunha de quatro tempos fundamentais, distintos entre si pela modulação e pelo andamento.

27 Andamento acima do normal na música.
} 
implícito um desejo em Kazuko de ser mãe e escolher Uehara como possível pai. Na segunda carta, Kazuko exterioriza o seu desejo e escreve: "[...] posso ser sua amante, eu quero ter um filho seu". As iniciais "M.C." tornam-se agora "My Child". Na terceira carta, fica explícito que Uehara somente foi o objeto de fertilização para a maternidade de Kazuko. As iniciais "M.C." significam agora "My Comedian".

O tema desse movimento se dá com o retorno de Naoji, com seus vícios, e a revolta de Kazuko, motivada pelas dívidas que Naoji impõe à família, bem como sua frustração por não ser mãe. Esse tema está diretamente ligado ao destino de Kazuko com suas revoltas. Isso fica claro no seguinte diálogo com a mãe:

- Mamãe, eu outro dia, estive pensando em que ponto o ser humano se
difere completamente dos outros animais, sabe? Palavras, inteligência,
raciocínio, ordem social, em tudo pode haver diferença de grau, mas todos
os outros animais são portadores dessas coisas, não acha? Até crenças é
possível que tenham. O homem orgulha-se de ser o rei da criação; no
entanto, não Ihe parece que não tem nada que o diferencie
fundamentalmente dos outros animais? Acontece, mamãe, que encontrei
uma única coisa. A senhora não sabe, não é? O que não existe em outro ser
vivo e há tão-só no homem. É o segredo... que me diz? (DAZAI, 1957,
Apêndice B, p. 189)

As cenas desse segundo movimento seguem o ritmo forte e cadenciado que acompanha o severo tempo de allegro assài ${ }^{28}$ de $s c h e r z 0^{29}$. Esse movimento é caracterizado por uma emoção além do comum no romance, muita energia da personagem, misturada com paixão, ansiedade e dúvida.

Terceiro movimento do Quarteto em Corda, de Mozart

O terceiro movimento se dá com um espaçoso tempo largo ${ }^{30}$, cresce e se transforma em uma marcha fúnebre (réquiem), até a morte da mãe de Kazuko. As cenas desse movimento são divididas em duas fases. A primeira fase é a

\footnotetext{
${ }^{28} \mathrm{Um}$ andamento um pouco mais rápido que o allegro comum.

${ }^{29}$ A palavra scherzo, de origem italiana, significa em português "brincadeira". Scherzo, em músicas, são trechos com três tempos, mais alegres que nos minuetos. Minueto, em italiano, significa "capricho", e scherzo, no teatro, significa "breve composição cômica".

30 Andamento lento na música.
} 
circunstância em que Kazuko se confronta com a difícil realidade de viver na miséria em companhia da mãe e a sua postura em aderir à idéia revolucionária de autodestruição. A segunda fase vai do momento em que é descoberta a tuberculose da mãe e se estende até a sua morte. Kazuko diz: "Meu peito hospeda uma serpente peçonhenta que engorda com o sacrifício dela". Juntas, as duas fases formam um movimento musical.

O tema desse movimento é a revolta de Kazuko, abandonada por Uehara, que não respondia suas cartas. Ela demostra sua angústia nessa passagem, ao escreverIhe uma carta dizendo:

[...] Esperando que os passos da felicidade ecoem no corredor, com tal ansiedade que chega a dilacerar o seu peito vazio? $\mathrm{Ai}$, como a vida é miserável! Enfrentar essa realidade é pensar que era melhor nem ter nascido. E, assim, esperar em vão, todos os dias [...]. (DAZAI, 1957, Apêndice B, p. 210)

O terceiro movimento se encerra na morte da mãe de Kazuko. Ele estipula a regra que segue à risca o formato rondo ${ }^{31}$ e largo, até a cena final, quando mostra o rosto da bela mãe como Maria de Pietà. Esse movimento se encerra como se fosse uma corrente de água. Está a velha mãe de Kazuko com sua passagem brilhante e o nascimento violento de uma nova mãe (Kazuko). São duas imagens de maternidade que dão uma impressão de independência desse capítulo.

Quarto movimento do Quarteto em Corda, de Mozart

A forma final do romance seriam os capítulos seis e sete. Nesses dois capítulos, como no primeiro movimento, existem os mesmos temas. Eles se misturam ferozes ao allegro e vão crescendo cada vez mais, até chegar ao começo da batalha. Essa forma de movimento começa quando a trombeta é tocada num som mais alto. Porem não é um som típico de uma sonata, mas o de um notável fugue.

31 A definição de rondo, de origem italiana, é o último tempo de uma sonata. 
Neste movimento há dois temas. O primeiro é o despertar de Kazuko para a maternidade. Ela oferece ao altar o seu sacrifício para acompanhar uma nova moral. Para isso, ela caminha altiva como uma figura corajosa. O segundo é a figura de Naoji, que vai de encontro com a morte. Pode-se dizer que aqui temos o renascimento. Nesse momento, Kazuko envia a última carta a Ueraha dizendo:

- Esta é a criança que Naoji secretamente teve com certa mulher. Por que eu procedo assim? Isso é uma coisa da qual eu não posso dizer a ninguém. Não, nem eu mesma sei por que lhe peço isso. Entretanto, estou ansiando que o senhor me faça esse favor. Por favor, peço-lhe por amor ao pequeno mártir chamado Naoji. (DAZAI, 1957, Apêndice B, p. 247)

Assim termina o quarto e último movimento, com a despedida de Kazuko. Nele fica evidente que, a partir desse momento, sua única preocupação passa a ser a maternidade. $O$ desejo de engravidar fora realizado após tantos anos de idealização.

Jinzai (1968), em seu artigo, diz que o romance Pôr-do-So/ está em forma de sonata, dizendo que Dazai, com certeza, não é somente um escritor talentoso, mas também extremamente detalhista. Por essa razão, Jinzai não poderia rotulá-lo de "escritor de improvisação". Ele conclui que de improvisação Pôr-do-Sol não tem nada, afirmando que Dazai tinha consciência exata quando escreveu o referido romance em forma musical.

Ainda segundo Jinzai (1968), além de um profundo conhecedor das artes ocidentais, nesse trabalho, Dazai reflete uma sensibilidade e gosto eclético pela musica clássica. A essência da obra de Dazai e sua técnica literária são muito criativas. Da melancolia do Pôr-do-So/ ele consegue apresentar o lirismo contido em sua obra, principalmente quando os críticos conseguem traçar um paralelo com a música clássica de Mozart. 


\section{Considerações Finais}

$\mathcal{N} a$ verdade, a alegria de estar juntos se esvai rapidamente; a tristeza de despedida é dolorosa. Geralmente não há muito a dizer quando nós vivemos no sentimento de partida. (Dazai Osamu).

O objetivo do presente trabalho de pesquisa é a apresentação da estética do espaço na obra Pôr-do-Sol, de Dazai Osamu. Nesse romance ele desenvolve narrativas que tratam da alma humana, do irracional, do onírico, da alegria e da desilusão atinentes a todos os seres humanos. A pesquisa foi desenvolvida com base na leitura da referida obra, bem como dos principais críticos da Literatura Japonesa que estudam as obras do autor. Em outro aspecto, houve a investigação dos elementos estéticos e simbólicos relacionados com a cultura japonesa, buscando sua representação e significação na obra Pôr-do-Sol.

Para situar o autor e sua obra dentro da Literatura Japonesa, foram feitos estudos do panorama literário prevalecente no pós-guerra de 1945. Para se chegar até a modernização ocorrida em 1945, o Japão passou pela abertura dos portos para o Ocidente na Restauração Meiji, em 1868. A aceleração da modernização afetou a vida cotidiana dos japoneses, transformando radicalmente a sociedade com a introdução de inovações advindas do Ocidente. Naturalmente, as mudanças ocorridas no período da guerra foram acompanhadas também nos meios literários, conforme apresentado nessa pesquisa.

A partir de 1868, muitos romancistas japoneses foram influenciados pela estética literária européia. Nesse período, vários escritores receberam apoio do governo para viajar à Inglaterra, Alemanha e França, entre outros países, a fim de assimilar novas técnicas narrativas e de constatar as novas tendências literárias da vanguarda européia para tornar o Japão integrado com os movimentos culturais mundiais. De acordo com o crítico literário Kobayashi Hideo (1902-1983), todos os 
romancistas modernos japoneses começaram no movimento naturalista, tendo como exceção os escritores Mori Ôgai e Natsume Sôseki, que estavam entre os escritores que vivenciaram as criações estrangeiras, mas não aderiram a esse movimento de vanguarda.

Muitos dos escritores japoneses tidos como naturalistas enveredaram pelo caminho do Watakushi Shôsetsu (Romance do Eu) influenciados por autores europeus, como André Gide, Marcel Proust e James Joyce. Gide e seus seguidores tentaram restabelecer a humanidade que havia desmoronado sob a pressão ideológica do Positivismo, no século XIX, criando um novo estilo literário onde o autor pudesse ter uma maior liberdade para falar de si em sua obra. Essa corrente foi denominada na Europa como Romance Confessional, e no Japão impulsionou o Romance do Eu. Na segunda metade da era Taishô (1912-1926), os escritores do Romance do Eu sentiram a necessidade de transformar as suas vidas em material literário adaptável que se encaixasse nos termos do movimento ao qual pertenciam, enfatizando o lado sombrio da vida humana, como exigiam as expectativas dos leitores. Com a importação e tradução dos romances autobiográficos contemporâneos de André Gide, Marcel Proust e James Joyce, atraíram um grande número de intelectuais japoneses e escritores como Dazai Osamu. Na década de 1930, Dazai iniciou a sua atividade como escritor engajado na literatura proletária ${ }^{32}$. A literatura proletária dominou o mundo literário japonês, mas com o avanço do militarismo e a censura, os partidários viram-se obrigados a converter-se para a política de ideologia imperialista (literatura de conversão). Dazai passou a escrever nos moldes do Romance do Eu autodestrutivo, que refletia a atmosfera de decadência e degeneração, utilizando-se do auto-escárnio, expondo as conturbações, libertinagens e outros aspectos negativos de sua vida.

Durante a Segunda Guerra Mundial, a atividade literária tornou-se escassa devido à censura por parte das autoridades governamentais e pela falta de recursos. Mesmo assim, Dazai conseguiu se sobressair com várias publicações, sendo uma delas Otogizôshi (Fábulas), recriação de quatro fábulas publicadas no período

\footnotetext{
32 Literatura proletária, corrente que surgiu no final da era Taishô (1912-1926) e no começo da era Shôwa (1926 - 1989).
} 
Muromachi (1392-1573). As quatro readaptações embora originariamente escritas para crianças são consideradas pelos críticos como de suma importância literária, visto que Dazai conseguiu durante o período da guerra criar histórias repletas de humor capazes de atenuar a realidade daquele período calamitoso do Japão.

Dazai passou por várias fases durante sua trajetória literária, sendo que no início de sua carreira, ele pertenceu à escola romântica. Após 1935, suas obras adquirem nuances da literatura proletária, do Romance do Eu e dos Decadentes. Percebe-se na obra Pôr-do-Sol uma forte influência do Naturalismo, porque nela temos os princípios de que o homem é o produto do meio, ou seja, os personagens sofrem a influência do meio ambiente na formação do caráter e eles vivem o momento histórico e a cultura a que estão sujeitos.

Pôr-do-Sol pode ser considerada, contudo, a obra marcante de sua carreira, já que retrata um momento histórico importante para a nação japonesa com a derrota na Segunda Guerra Guerra Mundial, trazendo a decadência da nobreza, o empobrecimento do povo e momentos de grandes dificuldades. Sua obra deu origem ao termo Shayôzoku (Tribo do Pôr-do-Sol), significando "tribo dos decadentes", que devido ao uso constante pelo povo japonês pela significação com a situação social, foi incorporada ao vocabulário e dicionário nacionais. Nela temos retratado o cotidiano da vida de uma família aristocrática decadente ao ser exilada para a pequena aldeia montanhosa de Izu.

De acordo com Chiba Sen'ichi (1988), a obra Pôr-do-Sol foi inspirada no diário de Ôta Shizuko, Shayô Nikki (Diário de Pôr-do-Sol), porém, a concepção inicial de Dazai era escrever Shayô com o nome de Jardim das Cerejeiras de Tsugaru. Isso em alusão à perda da propriedade de Tsugaru, pertencente à sua família, devido à reforma agrária ocorrida após a derrota do Japão na guerra. A idéia de Dazai era fazer analogia com a perda da propriedade ocorrrida na obra Jardim das Cerejeiras, de Anton Tchekhov.

Em Pôr-do-Sol há uma forte influência das obras Jardim das Cerejeiras e $A$ Gaivota, de Tchekhov, inclusive citadas dentro do romance. Arnold Hauser (2003) define Tchekhov como um escritor pertencente ao Naturalismo e Impressionismo. 
Segundo Tomiko Yanagi (1970), percebe-se que a obra de Dazai está intimamente ligada à obra de Tchekhov. Vários japoneses vêem a similaridade entre os quatro personagens de Jardim das Cerejeiras com os quatro personagens de Pôr-do-Sol. Não há dúvidas de que Dazai sofreu influências estrangeiras ao conceber as personagens do romance. Em várias passagens, Dazai cita Marx, Rosa Luxemburgo, Nietzsche, Tchekhov, Strindberg, Verlaine e faz menção à Revolução Francesa ao descrever a guilhotina, presente na brincadeira que Uehara fazia: "Guilhotina, guilhotina, zuuuup", coisa inexistente no Japão.

Outra característica naturalista da obra Pôr-do-Sol fica evidente com o enfoque dado ao cotidiano. Os personagens estão próximos de pessoas comuns da sociedade japonesas, com seus problemas do dia-a-dia, as suas angústias e desilusões. Nessa análise, os personagens contextualizam a realidade histórica do pós-guerra. Kazuko pode ser vista como a metonímia do povo japonês, porque busca reerguer-se da miséria e luta para alcançar seus ideais. Naoji representa a decadência da nobreza, é um ser subjugado pelo fator do determinismo e de seu comportamento social. Já a mãe deles representa a aristocracia, como última dama do Japão que desaparece. Outro enfoque naturalista recai sobre o autor Dazai, que escreveu sua obra ambientada em seu tempo contemporâneo, como estabelece o Naturalismo. A crítica social está enrustida na obra, enfocando a realidade da família decadente como conseqüência do meio e a perda dos bens dos abastados gerando a reforma agrária no país. Nesse sentido, a obra Pôr-do-So/ representa, no contexto do momento em que foi escrita, a queda do Império Japonês.

No que tange a visão estética da natureza de Dazai, de acordo com Torii Kunio (1999, p. 21), o autor era totalmente avesso à observação da natureza, embora na obra Fugaku Hyakkei (Cem Visões do Monte Fuji) possam ser encontradas descrições que contemplam a beleza natural do Monte Fuji. Para Torii (1999), Dazai utiliza-as apenas para externar sentimentos recriminatórios contra pessoas que exaltam cegamente o referido monte. Torii (1999) conclui que é impossível identificar a visão do autor sobre a natureza. 
A opinião de Tsuruya Kenzô (1996, p. 107-112, tradução nossa) coincide com a de Torii (1999) ao afirmar que: "[...] a visão do Fuji como algo sagrado e símbolo de espírito tradicional e valores ocidentais em relação aos importantes temas para intelectuais da época, como o colapso do ego, consciência própria excessiva e outros". Ele analisa, também, o significado do Fuji durante a guerra, ressaltando as características da época dominada pela tendência de mecanização e materialização de essências humanas, abolindo as posturas conceituais.

Entretanto, observa Tsuruya (1996) que é difícil visualizar as cores da guerra em Fugaku Hyakkei (Cem Visões do Monte Fuji), mas é possível ler as oscilações de sentimentos pessoais, de intriga de redescoberta de nova oscilação, de equilíbrio de forças e de harmonia na obra de Dazai. Tsuruya $(1996$, p. 107) exemplifica citando a frase dita por Dazai: "O Monte Fuji do Japão é belo, porque existe uma adoração prévia por ele $[. .$.$] ", o que, pela leitura de Tsuruya, leva a uma crítica velada da$ época que forçava a padronização e uniformização. Considerando que o espírito de verdade está na diversidade, falta de ordem e indefinição, Dazai critica as pessoas vulgares que só enxergam a verdade por um filtro padronizado (uma só maneira de ver). Para Tsuruya (1996), Dazai acredita que essas pessoas sequer duvidam desse seu comportamento ou da falta de consciência. Sendo assim, Dazai é apenas um crítico desse comportamento de padronização e da forma com que o povo japonês se comporta com relação à questão estética.

A idéia apresentada por Tsuruya (1996) é contraria à de Torii (1999) no que tange à capacidade de Dazai de observar a natureza e retratá-la com tanta eficácia em seus mínimos detalhes. A sensibilidade de Dazai reflete no estilo narrativo a que ele recorre com tanto esmero, enaltecendo o conteúdo de forma poética, como fez na obra Pôr-do-Sol. Na observação de Tsuruya (1996), Dazai era apenas contra a uniformização e padronização do povo japonês almejado pelo governo militar do pósguerra. A mesma estrutura narrativa de Cem Visões do Monte Fuji aparece em Pôrdo-Sol, inserindo a obra no contexto da época, onde Dazai não deixa transparecer as cores da guerra. Na obra Pôr-do-Sol o autor recorre ao seu filtro estético para atenuar alguns elementos, como a guerra, e evidenciar outros, como os fenômenos 
da natureza, as estações do ano, as floradas, os elementos simbólicos, entre outros. Assim, fica evidenciada a sua capacidade de observação e sensibilidade estética.

Dazai deixa transparecer, através do romance, a interferência da literatura ocidental inserindo em sua obra citações bíblicas do Cristianismo do Evange/ho Segundo Mateus. Para alguns leitores orientais isso pode denotar uma profundidade de conhecimentos históricos do Cristianismo, mas para outros pode causar o estranhamento pelo choque com a cultura religiosa oriental. 0 mesmo sentimento pode acometer os leitores ocidentais ao ler um romance europeu adornado com citações dos mestres zen budistas. Para uma obra concebida no caos do pós-guerra, Dazai insere o Evangelho Segundo Mateus de forma natural, como se todos os japoneses tivessem familiaridade com a cultura religiosa cristã. Para uma obra ocidental, o Cristianismo seria um elemento considerado natural, porém, para um país como o Japão, onde a maioria pratica o Xintoísmo e Budismo, e somente a minoria da população pratica o Catolicismo, isso é tido como incomum.

Nas obras do período inicial de Dazai, a técnica de narrar usava o amor e o ódio permeando a trama, muitas vezes marcados pelas lembranças da sua vida. Ocorre uma mudança na postura narrativa do escritor no período da guerra. Essa técnica se esvai, dando vez a um autor com uma maior sensibilidade estética e maior compreensão das questões do relacionamento humano. Dazai deixa transparecer que sua missão é escrever dentro da turbulência da sociedade e alinha a técnica de escrever acompanhando a correnteza da época. Ao mesmo tempo em que Dazai cita os elementos ocidentais nas obras, a partir de então, ele também referencia a literatura oriental da era Heian como Narrativas de Genji e Sarashina Nikki. Ao escrever Pôr-do-Sol, Dazai buscou inspiração no período Heian para embasar Diário de Naoji e Diário de Kazuko em uma época em que predominava a literatura em formato de diários.

Existem dois espaços na obra Pôr-do-Sol: o espaço idílico Tóquio, que representa o tempo passado, onde os personagens pertenciam à aristocracia japonesa no período anterior à guerra, e o espaço de exílio em Izu, que representa o tempo presente, onde os personagens vivem os seus conflitos devido à perda do status social ocasionado pela derrota na guerra. Em alguns momentos, no tempo 
presente da obra, Dazai apresenta as influências do espaço idílico Tóquio em contraponto a Izu, como se houvesse uma tênue ligação entre eles, apenas para representar o caos, os vícios, as desiluções, a decadência social e as paixões, entre outras emoções. Já em Izu temos os momentos de reflexão dos personagens e o reencontro com suas emoções mais íntimas. Dazai, em Pôr-do-Sol, fez uso do dualismo como técnica narrativa, onde apresenta o contraponto do novo com o velho, da metrópole com a província, do caos social com a pacata vida do campo, dos conflitos interpessoais com os conflitos intrapessoais, e do Japão imperialista com o Japão derrotado. O espaço se apresenta como o pano de fundo de um cenário, uma janela que convida o leitor a adentrar na trama. Os diários, as cartas e testamentos são transmissores de mensagens. Transportando as mensagens pelo tempo e possibilitando ao leitor decifrar os elementos da trama, faz com que o passado explique o presente. E os solilóquios são como um meio do leitor conhecer os pensamentos da narradora. Portanto, a presente análise demostra a importância desse recurso lingüístico que permeia os cronotopos da narrativa.

Mas nem tudo em Pôr-do-Sol é local. Dazai também invade os conflitos do homem universal, permitindo que o leitor ocidental se identifique com os personagens. Com isso se percebe um duplo valor na narrativa: a complexidade de um Japão devastado e as angústias que afligem o homem desde os primórdios, como a morte e a compreensão da vida.

A imagem descrita para realçar a beleza do espaço em harmonia com a experiência íntima da protagonista possui um valor pictórico típico de um artista plástico. Dazai utiliza o espaço como uma descrição pictórica dentro da narrativa para, com isso, realçar a beleza de Izu, que funciona como outra metonímia do Japão. Se de um lado o Japão é pura ruína, de outro, antiteticamente, ele é belo e cheio de possibilidades humanas que se mostram através da espacialidade, ou, mais especificamente, da temporalidade manifestada através do espaço físico.

Através das paisagens é possível captar a interioridade das personagens, 0 clima de transitoriedade e toda a representatividade que a natureza possui para 0 povo japonês. As descrições em Pôr-do-Sol exploram a beleza botânica que insurge 
resplandecente no meio de todo o caos. Nas telas espaciais pintadas pelo autor, a obra busca mostrar também que a decadência não é tudo que resta à vida daquelas personagens. Ainda existem o mar, as floradas e outros refúgios naturais que restauram um pálido otimismo pela existência mais satisfatória das coisas. Trata-se do Japão que restou intacto.

Dazai explora as estações do ano, apontando, por meio delas, o valor cíclico da existência - nascimento, vida e morte. As estações funcionam como bússolas emocionais, acenando para os leitores que cada estação tem a sua função bem definida na vida das personagens. Assim, o espaço surge como um dos elementos constitutivos da força estética da obra. $O$ autor não economiza recursos poéticos para descrever as imagens. Com isso ampliam-se as possibilidades de desvendar alguns importantes aspectos estilísticos.

Cabe destacar também o detalhismo de Dazai na construção do espaço, que é minuciosamente preenchido com espécies florais, como crisântemos, peônias, ameixeiras, quérrias, cerejeiras, entre outros elementos florais. A mãe de Kazuko sempre está inserida nesse contexto poético como se fosse uma personagem da pintura. A sua frágil saúde pode ser comparada à transitoriedade da vida de uma flor, quando, após a sua morte, o cenário floral desaparece. A simbologia da flor de crisântemo como o brasão da nobreza desaparece com a morte da mãe, a última das nobres, segundo palavras de Kazuko. Dazai, com sua técnica narrativa, através do detalhamento da natureza, colore o pano de fundo do cronotopo e permite que 0 leitor estenda sua visão para dentro do ambiente da obra, como se houvesse uma "janela" que possibilitasse isso. Ele descreve a natureza com o propósito de dar sentido à efemeridade do tempo, tanto da natureza como o da vida humana.

A tese de que Pôr-do-Sol possua musicalidade e ritmo, compasso e cadência, segundo Jinzai Kiyoshi (1968) e demais literatos japoneses, apresenta a possibilidade de que Dazai teve intencionalidade e criatividade ao relacionar o espaço pictórico e estético com um espaço musical. Jinzai organizou esse ensaio a fim de discutir a similaridade da obra com o Quarteto em Corda de Mozart, buscando a relação entre os quatro movimentos em função dos tempos, modulação e andamento da música, 
com as ações, conflitos e emoções dos personagens. Portanto, o espaço musical proposto convidaria o leitor a "ouvir" o ritmo da vida dos personagens, ou seja, ampliar a percepção da transitoriedade da vida humana apresentada por Dazai na obra.

Por fim, cabe ressaltar que este trabalho de pesquisa apresenta novos parâmetros para análise das obras de Dazai para todos os interessados na cultura oriental, para fins de estudos que tragam aprimoramento às pesquisas acadêmicas sobre a Literatura Japonesa. O objetivo principal é o de difundir a cultura japonesa entre os brasileiros e nikkeis que anseiam por leitura de bons escritores japoneses. Dazai Osamu é um dos escritores mais traduzidos na língua inglesa, portanto, espera-se com esse trabalho não esgotar a interpretação de sua obra e impedir outros olhares. Ao contrário, visa estimular novas pesquisas que possibilitem uma análise mais ampla de outros aspectos não abordados na presente pesquisa, ou de traduções de outras obras desse autor. Contudo, almeja-se também, com essa pesquisa, desmistificar a idéia de alguns críticos, como Tsuruya Kenzô (1996), de que Dazai seja dotado de ausência de sensibilidade para observar a natureza. Tão polêmico, Dazai, através das ambigüidades do mundo real, consegue externar as sensações verdadeiras e as trivialidades da vida na sua obra de forma dualista, poética e estética.

A análise de Pôr-do-Sol apresenta a importância do autor na Literatura Japonesa, bem como acrescenta novos elementos para a interpretação da vida humana associada a essa cultura. 


\section{Referências}

ADORNO, Theodor W. Dialética do conhecimento: fragmentos filosóficos. Rio de Janeiro: Jorge Zahar, 1985.

Idéias para a sociologia da música. BENJAMIN, Walter; HORKHEIMER, Max; ADORNO, Theodor W.; HABERMAS, Jurgen. Textos escolhidos. Tradução José L. Grünnewald et al. São Paulo: Abril Cultural, 1983. p. 259-268. (Os pensadores).

. Notas da literatura I. Tradução Jorge de Almeida. São Paulo: Editora 34, 2003. Coleção Espírito Crítico.

ANDO, Hiroshi. Dazai bungaku ni okeru <josei> (As mulheres da literatura de Dazai). Kokubungaku: kaishaku to kanshô (Literatura nacional: interpretação e apreciação). Tôkyô, JP: Shibundo, v. 64, n. 9, p. 15-19, 1 set. 1999. Tokushû: Dazai Osamu no nazo (Edição especial: Enigma de Dazai Osamu).

ASTON, William G. A history of japanese literature. Tôkyô, JP: Charles E. Tutle, 1975.

AUERBACH, Erich. Mimesis: a representação da realidade na literatura ocidental. 5. ed. São Paulo: Perspectiva. 2004.

BACHELARD, Gaston. A filosofia do não; o novo espírito científico; a poética do espaço. Tradução Joaquim J. M. Ramos et al. São Paulo: Abril Cultural, 1978. p. 181-354. (Os Pensadores).

BAIRD, Merrily. Symbols of Japan. New York, US: Rizzoli International Publications, 2001.

BAKHTIN, Mikhail. Questões de literatura e de estética. São Paulo: Hucitec, 1990.

Estética da criação verbal. São Paulo: Martins Fontes, 2000. 
A cultura popular na Idade Média e no Renascimento: o contexto de François Rabelais. Tradução Yara Frateschi Vieira. São Paulo: Hucitec, 1987.

BAN, Etsu. Dazai Osamu no Josei Kan (A visão sobre as mulheres de Dazai Osamu). Kokubungaku: Kaishaku to Kanshô (Literatura Nacional: Interpretação e apreciação). Tôkyô, Jp: Shibundo, v. 61 n. 6, p. 43-49, jun.1996. Tokushû: Dazai Osamu, sotsugyô ronbun he no shishin (Edição especial Dazai Osamu, teses de formatura).

BARBOSA, Sidney (Org.). Tempo, espaço e utopia nas cidades. Araraquara: Cultura Acadêmica Editora, 2004. (Série Estudos Literários, n. 4).

BENJAMIN, Walter. Sobre arte, técnica, linguagem e política. Tradução Maria L. Moita, Maria A. Cruz e Manuel Alberto. Lisboa, PT: Relógio D’Água Editores, 1992.

et al. Textos escolhidos. São Paulo: Abril Cultural, 1983. (Os Pensadores).

CAMPEDELLI, Samira Y. Literatura, história \& texto 2. São Paulo: Editora Saraiva, 2003.

CANDIDO, Antonio. Tese e antítese. 5. ed. São Paulo: Ouro Sobre Azul, 2006.

CANDIDO, Antonio; ROSENFELD, Anatol; PRADO, Décio A.; GOMES, Paulo E. S. A personagem de ficção. 9. ed. São Paulo: Perspectiva, 1995.

CHEVALLIER, Jean; GHEERBRANT, Alain. Dicionário de símbolos: mitos, sonhos, costumes, gestos, formas, figuras, cores, números. Coordenação Carlos Sussekind. Tradução Vera C. Silva et al. 7a ed. Rio de Janeiro: José Olympio, 1982 e 1999.

CHIBA, Sen'ichi. Shayô Shiron: Shayô Nikki no hyôsetsu wo meguru mondai (Ensaio de Pôr-do-Sol: problema acerca do plágio do Diário de Pôr-do-Sol). Kokubungaku: kaishaku to kanshô (Literatura nacional: e interpretação e apreciação). Tôkyô, JP: Shibundo, v. 53, n. 6, p. 111-117, 1 jun. 1988. Tokushû: Dazai Osamu shôwa 20 nen 23 nen (Edição especial: Dazai Osamu de 1945 a 1948).

CHKLOVSKI, Victor. A arte como procedimento. In: EIKHENBAUM, Boris et al. Teoria da literatura: formalistas russos. Porto Alegre: Globo, 1971. p. 39-56.

CUNHA, Betina R. R. A poética da natureza na obra de Eluard e Bandeira. São Paulo: Annablume, 2000. 
DAZAI, Osamu. Crackling mountain and other stories. Tradução James O'Brien. 1. ed. Tôkyô, JP: Charles E. Tutle, 1989. Título original: Kachi Kachi Yama.

Ha (Folhas). In: SHINCHÔ (Org.). Dazai Osamu shû. (Coletânea Dazai Osamu). Tôkyô, JP: Kabushiki Gaisha, Shinchôsha, 1969. p. 7-16. Nihon Bungaku, 35 (Literatura Japonesa, v. 35).

. Hashire Merosu (Corra Melos). In: KAWAHASHI, Yasunari; ITO, Sei. (Org.). Nihon no Bungaku (Literatura do Japão). Tôkyô, JP: Kabushiki Gaisha, Shûeisha, 1972. v. 13.

Hashire Merosu. (Corra Melos). Kôsei sha Kadogawa Bunko (Organização Biblioteca Kadogawa). Tôkyô, JP: Kabushiki Gaisha, Kadogawa Shoten, 1970.

Indigno de ser humano. Tradução Montse Watkins. Ilustração Tadahiko Hayashi. Kanagawa Ken, JP: Luna Books, Tôkyô, JP: Gendai Kikakushitsu, 1999. Título original: Ningen Shikkaku.

. Joseito (A Estudante). In: KAWAHASHI, Yasunari; ITO, Sei. (Org.). Nihon no bungaku (Literatura do Japão). Tôkyô: Kabushiki Gaisha, Shûeisha, 1972. v. 13.

. Matsu (A Espera). In: KAWAHASHI, Yasunari; ITO, Sei. (Org.). Nihon no bungaku (Literatura do Japão). Tôkyô: Kabushiki Gaisha, Shûeisha, 1972. v. 13.

. No longer human. 1. ed. Tradução Donald Keene. Tôkyô, JP: Charles E. Tutle, 1981. Título original: Ningen shikkaku.

- Otogizôshi (Fábulas). In: TORII, Yutaka (Org.). Dazai Osamu zenshû (Coleção completa de Dazai Osamu). Tôkyô, JP: Hatsukumo Shoten, 1939. p. 207367. (v. 11).

. Omoide (Lembranças). In: KAWAHASHI, Yasunari; ITO, Sei. (Org.). Nihon no bungaku (Literatura do Japão). Tôkyô: Kabushiki Gaisha, Shûeisha, 1972. (v. 13).

. Pôr-do-Sol. Tradução Antonio Nojiri. Ilustração Yûji Tamaki. São Paulo: Hamburg, 1974. Título original: Shayô. 
. Return to Tsugaru: travel to a purple tramp. Tradução James Westerhoven. Fotografias Tôkyô, JP: Kodansha International, 1985. Título original: Tsugaru.

. Seigi to bishô (Justiça e Sorriso). KAWAHASHI, Yasunari; ITO, Sei. (Org.). Nihon no bungaku (Literatura do Japão). Tôkyô: Kabushiki Gaisha, Shûeisha, 1972. (v. 13).

. The setting sun. Tradução Donald Keene. New York, US: Charles E. Tuttle Company Publishers, 1981.

. Shayô (Pôr-do-Sol). In: SHINCHÔ (Org.). Dazai Osamu shû. (Coletânea Dazai Osamu). Tôkyô, JP: Kabushiki Gaisha, Shinchôsha, 1969. p. 206-294. Nihon bungaku, 35 (Literatura japonesa, v. 35).

. Shayô (Pôr-do-Sol). In: ITO, Sei et al. (Org.). Dazai Osamu shû. (Coletânea Dazai Osamu). Comentários Kôda Susumu e Okuno Takeo. Tôkyô, JP: Shûeisha, 1957. p. 07-111 e 384-386. Nihon Bungaku Zenshû, 70 (Coleção completa da Literatura Japonesa, v. 70).

. Shayô (Pôr-do-sol). SHINCHÔ (Org.). Shayô to Ningen shikkaku: Dazai Osamu. (Pôr-do-sol e Desqualificado como ser humano: Dazai Osamu). Tôkyô, JP: Kabushiki Gaisha, Shinchôsha, 1979. p. 7-102. Gendai Bungaku, 20 (Literatura Contemporânea, v. 20).

DIMAS, Antonio. Espaço e romance. 3. ed. São Paulo: Ática, 1994.

GESSEL, Van C.; MATSUMOTO, Tomome. The Shôwa anthology: modern japanese short stories; 1929-1984. Tôkyô, JP: Kodansha International, 1989.

HATOUM, Milton. O espaço geográfico no romance brasileiro. Salvador: Fundação Casa de Jorge Amado, 1993.

HAUSER, Arnold. História social da arte e literatura. Tradução Álvaro Cabral. São Paulo: Martins Fontes, 2003. cap. 7, p. 727-955 e 1024-1032.

HIRANO, Ken. Watakushi Shôsetsu no niritsu haihan. (Antinomia do Romance do Eu) In: Hirano Ken zenshû. (Coleção completa de Hirano Ken). Tôkyô, JP: Shinchôsha, 1975. (v. 2). 
ITO, Sei et al. (Org.). Dazai Osamu shû. (Coletânea Dazai Osamu). Ilustrações Fukuoka Ken'nichi. Tôkyô, JP: Shûeisha, 1957. Nihon Bungaku Zenshû, 70 (Coleção completa da Literatura Japonesa, v. 70).

JINZAI, Kiyoshi. Shayô no mondai (Problema de Pôr-do-Sol). In: OKUNO, Takeo. Dazai Osamu kenkyû (Pesquisa sobre Dazai Osamu). Tôkyô, JP: Chikuma Shobo, 1968. p. 103-114.

KAKUTA, Ryojin. Otogizôshi: kodoku he no tonsôkyoku. (Fábulas: fuga musical para a solidão). Kokubungaku: kaishaku to kanshô (Literatura Nacional: interpretação e apreciação). Tôkyô, JP: Shibundo, v. 52 n.6, p.130-134, jun. 1987. Tokushû Dazai Osamu shôwa 13 nen 20 nen (Edição especial Dazai Osamu de 1938 a 1945).

KARATANI, Kôjin. Origins of modern japanese literature. Tradução Brett De Bary. Durham, NC, US: Duke University Press, 1993.

KASAI, Akifu. Dazai Osamu to kirisuto kyô: shôwa jûichi nen zengo ni okeru seishô to no kakawari. (Dazai Osamu e o cristianismo: relação com a bíblia nos anos de 1936). Dazai Osamu kenkyû. (Estudos sobre Dazai Osamu). Tôkyô, JP: Oizumi Shoin, v. 02, p. 15-29, 1996.

KATO, Shuichi. A history of japanese literature. 3. ed. Tôkyô, JP: Kodansha International, 1990.

KAYSER, Wolfgang. Análise e interpretação da obra literária: introdução à ciência da literatura. Tradução Paulo Quintela. 2. ed. Coimbra, PT: Armênio Amado, 1958. (Studium, v. 1).

KEENE, Donald (Ed.). Anthology of japanese literature: from the earliest era to the mid-nineteenth century. New York, US: Grove Press, 1955.

1981.

Appreciation of japanese culture. Tôkyô, JP: Kodansha International,

Dawn to the West: japanese literatures in the modern era, fiction. New York, US: Columbia University Press, 1998. (A history of japanese literature, v. 3).

. Love suicides at Amijima. New York, US: Columbia University Press, 1961. Major Plays of Chikamatsu (Coletânia). 
Seeds in the heart: japanese literatures from earliest times to the late sixteenth century. New York, US: Columbia University Press, 1999. (A history of japanese literature, v. 1).

World within walls: japanese literatures of the pre-modern era, 16001867. New York, US.: Columbia University Press, 1999. (A history of japanese literature, v. 2).

Kenbetsu shirizu kyodô shiryô jiten (Dicionário de dados e séries geográficas). Tôkyô, JP: Jinbunsha, 1987. (v. 20). Shizuoka Ken Kankô to Tabi (Província de Shizuoka: passeio e viagem).

KOBAYASHI, Hideo. Literature of the lost home. Tradução Paul Anderer. Stanford, CA, US: Stanford University Press, 1995.

KOIZUMI, Kôichirô. Yamagishi Gaishi: ningen Dazai Osamu. (Yamagishi Gaishi: o ser humano Dazai Osamu). Kokubungaku: kaishaku to kanshô (Literatura Nacional: interpretação e apreciação). Tôkyô, JP: Shibundo, v. 55 n. 11, p. 97, nov.1990. Tokushû Dazai Osamu kenkyû no tameni (edição especial para estudos sobre Dazai Osamu).

KOKUSAI, Bunka Shinkôkai (Org.). Synopses of contemporary japanese literature II: 1936-1955. Yokohama, JP: General Printing, 1970. (Japanese Life and Culture Series).

LEWELL, John (Ed.). Modern japanese novelists: a biographical dictionary. Tôkyô, JP: Kodansha International, 1993.

LUKÁCS, Georg. A teoria do romance. Tradução José M. M. Macedo. São Paulo: Duas Cidades; Editora 34, 2000. (Coleção Espírito Crítico).

LYONS, Phyllis I. The saga of Dazai Osamu: a critical study with translations. Stanford, CA, US: Stanford University Press, 1985.

MIYASAKA, Satoru. Dazai Osamu to Akutagawa Ryûnosuke. Kokubungaku: Kaishaku to Kanshô (Literatura Nacional: interpretação e apreciação). Tôkyô, JP: Shibundo, v. 63, n. 6, p. 49 - 53, jun. 1998. Tokushû Dazai Osamu Botsugô gojûnen (Edição especial: Dazai Osamu cinqüenta anos da morte). 
MIYATA, Masayuki; ÔOKA, Makoto; LEVY, Ian H. Love songs the Man'yôshû: selections from a Japanese classic. Tradução Ian $\mathrm{H}$. Levy. Ilustração Miyata Masayuki. Tôkyô, JP: Kodansha International, 2000.

NAGAE, Neide Hissae. De Katai a Dazai: apontamentos para uma morfologia do romance do Eu. 2006. 155 f. Tese (Doutorado em Teoria Literária e Literatura Comparada). Faculdade de Filosofia, Letras e Ciências Humanas, Universidade de São Paulo, 2006.

Ficção e realidade em trajetória em Uma Noite Escura (An'ya Kôro) de Shiga Naoya. 1999. 151 f. Dissertação (Mestrado em Língua, Literatura e Cultura Japonesa). Faculdade de Filosofia, Letras e Ciências Humanas, Universidade de São Paulo, 1999.

NAKAMURA, Miharu. Shayô no dekadansu to "kakumer" ("Revolução" e decadência de Pôr-do-sol). Kokubungaku: kaishaku to kyôzai no Kenkyû (Literatura nacional: interpretação e pesquisa de material educativo). Tôkyô, JP: Shibundo, v. 44, n. 7, p. 94-101, jun. 1999. Henbô suru Dazai Osamu: botsugo gojûshûnen (Dazai Osamu que transforma: aniversário da morte de cinqüenta anos).

NIPPON GAKUJUTSU SHINKÔKAI (Associação de Pesquisas do Japão) (Org.). The Manyôshû: one thousand poems (Coletânea de Dez mil folhas). New York, US.: Columbia University Press, 1969.

NOHARA, Kazuo. Kaisô Dazai Osamu (Retrospectiva Dazai Osamu). Tôkyô, JP: Shinchôsha, 1980.

NOSAKA, Yukihiro. Dazai Osamu to fûdô-shizen (Natureza e o regionalismo de Dazai Osamu). Kokubungaku: kaishaku to kyôzai no Kenkyû (Literatura nacional: interpretação e pesquisa de material educativo). Tôkyô, JP: Shibundo, v. 32 n. 1, p. 92-93, jan. 1987.

NOSAKA, Yukihiro. Dazai Osamu shûen he no naratorojii (Dazai Osamu: narratologia para a morte) Kokubungaku: kaishaku to kyôzai no Kenkyû (Literatura nacional: interpretação e pesquisa de material educativo). Tôkyô, JP: Shibundo, v. 32 n. 1, p. 136-137, jan. 1987.

NUNES, Benedito. 0 tempo na narrativa. São Paulo: Ática, 2002. (Série Fundamentos). 
ODAGIRI, Hiroko; MORRELL, Robert. The princeton companion to classical japanese literature. New Jersey, US: Princeton University Press, 1985.

OKUNO, Takeo Hen. Dazai Osamu kenkyû (Estudos sobre Dazai Osamu). Tôkyô, JP: Chikuma Shobô, 1968.

. Dazai Osamu no shôgai to sakuhin (Vida e obra de Dazai Osamu). In: KAWAHASHI, Yasunari; ITO, Sei. (Org.). Nihon no Bungaku (Literatura do Japão). Tôkyô: Kabushiki Gaisha, Shûeisha, 1972. (v. 13).

ÔTAKA, Tomoji. Dazai Osamu to senkô bungaku; Dazai Osamu ni okeru Akutagawa Ryûnosuke (Dazai Osamu e a literatura precedente; Dazai Osamu que está em Akutagawa Ryûnosuke). Kokubungaku: kaishaku to kanshô (Literatura nacional: interpretação e apreciação). Tôkyô, JP: Shibundo, v. 50, n. 12, p. 51-56, nov. 1985. Tokushû Dazai Osamu shôwa 8 nen 12 nen (Edição especial Dazai Osamu de 1933 a 1937).

POLLACK, David. Reading against culture: ideology and narrative in the japanese novel. London, UK: Cornell University Press, 1992.

POUILLON, Jean. 0 tempo no romance. Tradução Heloysa L. Dantas. São Paulo: Cultrix; Edusp, 1974.

POWELL, Irena. Writers and society in modern Japan. Tôkyô, JP: Kodansha International, 1983.

RIMER, J. Thomas. A reader's guide to japanese literature. Tôkyô, JP: Kodansha International, 1990.

Dazai Osamu: the death of the past The Setting Sun. Modern japanese fiction and it's traditions an introduction. New Jersey, US: Princeton University Press, 1978. cap. 10, p. 182-199.

SEIDENSTICKER, Edward G. Kobayashi Hideo. In: SHIVELY, Robert (ed.). Tradition and modernization in japanese culture. Princeton, US: Princeton University Press, 1971.

SEKII, Mitsuo. Dazai Osamu to gaikoku bungaku aruiwa inyô no shûjigaku. (Dazai Osamu e a literatura estrangeira ou citação da retórica). Kokubungaku: kaishaku to kanshô (Literatura nacional: interpretação e apreciação). Tôkyô, JP: Shibundo, v. 50, 
n. 12, p. 43-49, Nov. 1985. Tokushû Dazai Osamu shôwa 8 nen 12 nen (Edição especial Dazai Osamu de 1933 a 1937).

. "Kyôgen no Kami" aruiwa gengo no kenchiku kûkan ("Deus da Farsa" ou a linguagem de construção do espaço). Kokubungaku: kaishaku to kanshô (Literatura nacional: interpretação e apreciação). Tôkyô, JP: Shibundo, v. 48, n. 9, p. 71-77, jun. 1983. Tokushû Dazai Osamu (Edição especial Dazai Osamu).

SÔMA, Shoichi. Shayô nikki no originarite (A originalidade do diário de Pôr-do-sol). Kokubungaku: kaishaku to kanshô (Literatura nacional: interpretação e apreciação). Tôkyô, JP: Shibundo, v. 44, n. 7, p. 109-115, 1 jun. 1999. Botsugo gojusshûnen: hembô suru Dazai Osamu (Aniversário de 50 anos morte: Dazai Osamu que se transforma).

- Dazai Osamu to fûdô (Dazai Osamu e as características regionais). Kokubungaku: kaishaku to kanshô (Literatura nacional: interpretação e apreciação). Tôkyô, JP: Shibundo, v. 61, n. 6, p. 22-28, 1 jun. 1996. Tokushû: Dazai Osamu, sotsugyô ronbun he no shishin (Edição especial: Dazai Osamu, teses de formatura indicadas).

SUZUKI, Tomi. Narrating de self: fiction of japanese modernity. Stanford, CA, US: Stanford University Press, 1996.

TAKEKOSHI, Yukio. Hyôden Dazai Osamu (biografia crítica Dazai Osamu). Kokubungaku: Kaishaku to Kanshô (Literatura Nacional: Interpretação e apreciação). Tôkyô, JP: Shibundo, v. 52 no 6, p.136-139, jun.1987 Tokushû Dazai Osamu shôwa 13 nen 20 nen (Edição especial Dazai Osamu de 1938 a 1945).

TARDIÉ, Jean-Yves. A crítica literária no século XX. Rio de Janeiro: Bertrand Brasil, 1992.

TCHEKHOV, Anton. As três irmãs. Tradução Gabor Aranyi. São Paulo: Abril Cultural, 1981. p. 67-129. (Em Cartaz, v. 2).

O jardim das cerejeiras; Teatro II: As três irmãs / O Jardim das cerejeiras. Tradução Gabor Aranyi. São Paulo: Abril Cultural, 1981. p. 67-129. (Em Cartaz, v. 2).

TODOROV, Tzvetan. As categorias da narrativa literária. In: BARTHES, Roland et al. Análise estrutural da narrativa: pesquisas semiológicas. Tradução Maria Z. B. 
Pinto. Petrópolis, RJ: Vozes, 1971. p. 211-256. (Novas Perspectivas de Comunicação, v. 1).

TÔGÔ, Katsumi; TSUSHIMA, Kôichi. Dazai Osamu shûen he no naratorojii (A narratologia para a morte de Dazai Osamu). Kokubungaku (Literatura Nacional). Tôkyô, JP: Kabushiki Gaisha, Gakutôsha, v. 32, n, 1, p. 40-59, jan. 1987. Dazai Osamu to Tsushima Ie no Hitobito (Dazai Osamu e as pessoas da casa de Tsushima).

TORII, Kunio. Dazai Osamu no shizen kan. (A perspectiva da natureza de Dazai Osamu). Kokubungaku: kaishaku to kanshô (Literatura nacional: interpretação e apreciação). Tôkyô, JP: Shibundo, v. 64, n. 9, p. 20-24, 1 set. 1999. Tokushû: Dazai Osamu no nazo (Edição especial: enigma de Dazai Osamu).

TSURUYA, Kenzô. Fugaku hyakkei: sono kôzo to toki no nagare (Cem Visões do Monte Fuji: sua estrutura e o transcorrer dos tempos). Kokubungaku: kaishaku to kanshô (Literatura nacional: interpretação e apreciação). Tôkyô, JP: Shibundo, v. 61, n. 6, p. 107-112, 1 jun. 1996. Tokushû: Dazai Osamu, sotsugyô ronbunhe no shishin (Edição especial: Dazai Osamu, teses de formatura indicadas).

YANAGI, Tomiko. Shayô ni tsuite (Sobre Pôr-do-sol). Nihon bungaku shiryô sôsho (Coletânea de dados para estudo da Literatura Japonesa). Tôkyô, JP: Yûseidô, 1970. p. 166-176. (Dazai Osamu, v. 1).

WADA, Toshie. Shayô. (Pôr-do-Sol). Kokubungaku: kaishaku to kanshô (Literatura nacional: interpretação e apreciação). Tôkyô, JP: Shibundo, v. 61, n. 6, p. 137-142, 1 jun. 1996. Tokushû: Dazai Osamu, sotsugyô ronbun he no shishin (Edição especial: Dazai Osamu, teses de formatura indicadas).

WELLEK, René; WARREN, Austin. O estudo intrínseco da literatura. Teoria da literatura e metodologia dos estudos literários. Tradução Luis C. Borges. São Paulo: Martins Fontes. 2003. Parte 4, p. 177-368.

WOLFE, Alan. Suicidal narrative in modern Japan: the case of Dazai Osamu. New Jersey, US: Princeton University Press, 1990. 


\title{
Apêndice A
}

\section{Cronologia da Vida de Dazai Osamu e suas Obras ${ }^{1}$}

\begin{abstract}
Para todo o trabalho histórico literário, é de maior importância saber-se qual o ano do aparecimento ou da elaboração de uma obra literária. O estabelecimento de dependências, de coincidências e evoluções depende em grande medida da fixação da data. (KAYSER, 1958, p.56)
\end{abstract}

1909

- Em 19 de junho nasce Tsushima Shûji, na vila Kanagi, distrito de Tsugaru, no extremo norte do Japão, na província de Aomori. Shûji era o décimo filho do casal Tsushima Gen'emon e Tane. Dois filhos do casal morreram ainda crianças. Gen'emon, ao se casar com Tane, foi adotado pela família Tsushima, em 1888, por não haver filhos homens na família. Em Aomori, Gen'emon era proprietário de enorme extensão de terra e participava do círculo político na prefeitura local.

1911 (2 anos)

- Take, na época com 14 anos de idade, vem a ser a ama-seca de Dazai.

1912 (3 anos)

- Sua irmã mais velha falece, e nasce o irmãozinho Reiji. O Imperador Meiji falece, e o Imperador Taishô ascende ao trono.

1916 (7 anos)

- Janeiro: vai para Goshogawara com sua tia, cuja filha se casa. Take não os acompanha.

- Abril: retorna à Kanagi para ingressar no primeiro ano primário.

- Dezembro: falece a avó.

1922 (13 anos)

1 Traduzido e adaptado para o português. Fonte: LYONS, 1985; LEWELL, 1993. 
- Abril: começa o ano de admissão para ingressar no ginasial, para mais tarde cursar o colegial.

- Ensaio: Boku no Yôji (Minha Infância).

1923 (14 anos)

- Março: o pai falece em Tóquio.

- Abril: ingressa no Colégio de Aomori. Começa a escrever.

- Setembro: um grande terremoto destrói a maior parte de Tóquio e Yokohama.

1925 (16 anos)

- Começa a pensar em ser escritor. Com os colegas da escola, publica duas revistas literárias intituladas Seiza (Constelação) e Shinkirô (Miragem).

1926 (17 anos)

- Setembro: com seus irmãos, começa a escrever a revista Aombo (Grande Menino Azul). O Imperador Taishô falece, e Hirohito, Imperador Shôwa, ascende ao trono.

1927 (18 anos)

- Abril: ingressa na Faculdade de Hirosaki no Departamento de Literatura. Interessa-se pela cultura Edo e começa a estudar Gidayû.

- Outubro: encontra uma jovem, Oyama Hatsuyo, de Beniko, como era conhecida.

- 24 de julho: o escritor Akutagawa Ryûnosuke comete suicídio.

1928 (19 anos)

- 15 de março: derrubada do Partido Comunista em todo o território japonês, quando cerca de 1.600 pessoas foram presas.

- Maio: publica, com amigos, a revista Saibô Bungei (Literatura Enclausurada). Começa a envolver-se com atividades da política de esquerda. 
- Verão: vai para Tóquio com o intuito de se encontrar com Ibuse Masuji, mas o encontro não se concretiza.

- Dezembro: torna-se membro e empregado do colegiado jornalístico e da revista Saibô Bungei.

Obras: Mugen Naraku (Inferno Sem Fim) e Aware Ga (Pobre mariposa).

1929 (20 anos)

- Janeiro: morte do irmão mais novo, Reiji.

- Fevereiro: greve escolar em protesto contra a má administração da Diretoria. Começa a escrever Jinushi Ichidai (A Vida dos Proprietários de Terras).

- Dezembro: noite de 10 de dezembro, primeira tentativa de suicídio ingerindo sonífero em grande quantidade. $\mathrm{Na}$ tarde do dia seguinte, recobra a consciência. Passa um mês se recuperando nas termas de Ôwani, juntamente com a sua mãe.

- 29 de outubro: a queda da Bolsa de Valores de Nova Yorque, nos EUA, leva o mundo à grande depressão.

- Obra: Jinushi Ichidai (A Vida do Senhor das Terras).

1930 (21 anos)

- Abril: ingressa na Universidade Imperial de Tóquio, no Departamento de Literatura Francesa. Encontra Ibuse Masuji. Ele se torna seu mentor profissional e pessoal. Ibuse fora apresentado a Dazai pelo ex-colega de classe de Hirosaki. Desde então, começa a contribuição mensal de dez ienes para o movimento de esquerda.

- Junho: o irmão Keiji falece em Tóquio.

- Outubro: Hatsuyo livra-se do contrato de gueixa e vai a Tóquio. 0 irmão mais velho de Dazai, Bunji, chega a Tóquio a fim de discutir a situação e leva Hatsuyo de volta para Aomori.

- Novembro: Dazai é deserdado do registro familiar. Tenta se suicidar com a garçonete Shimeko Tanabe em Enoshima (mais precisamente no 
local chamado Koyurugigasaki, localizado na ilha principal no lado oposto de Enoshima). A garçonete falece. Dazai é acusado de cúmplice pela morte da moça, mas é posto em liberdade.

- Dezembro: Dazai recupera-se nas termas de Ikarigaseki. Lá, ele se casa com Hatsuyo, na presença de sua mãe. Ele continua escrevendo $A$ vida do Senhor de Terras (obra inacabada).

1931 (22 anos)

- Janeiro: retorna para Tóquio. Ele e Hatsuyo se mudam com freqüência.

- Abril: é interrogado pela polícia sobre suas atividades políticas. Libertado da prisão sob o pagamento de fiança pelo amigo de seu irmão Reiji, Tobishima Sadahiro.

- Julho: é interrogado novamente pela polícia. Interessa-se em escrever haiku, sob o nome de Shûrindô.

- Setembro: o incidente de Manchúria sinaliza que o Japão quer a expansão militar sobre a China.

1932 (23 anos).

- Abril: é interrogado novamente pela polícia. Solto sob fiança paga por Kita Yoshihiro. O irmão, Bunji, fica enfurecido e suspende a ajuda mensal de 120 ienes, mas após dois meses de suspensão, ele a restabelece, reduzindo-a para 90 ienes mensais.

- Julho: toma conhecimento do passado de Hatsuyo (ex-geisha). Intimado para um interrogatório pela polícia de Aomori, ele rompe com a esquerda.

- Agosto: vai à cidade de Numazu com Hatsuyo, para relaxar.

- Setembro: eles retornam para Tóquio e mudam-se para Tobishima. Começa a escrever Omoide (Lembranças) e Bannen (Últimos Anos).

- Dezembro: é chamado a Aomori pela polícia, para interrogatório, sendo liberado em seguida.

$\checkmark$ Obra: Ressha(O Trem). 
1933 (24 anos)

- Janeiro a maio: fica acamado em conseqüência de ataque de tuberculose.

- Fevereiro: utiliza pela primeira vez o pseudônimo Dazai Osamu. Com a história Ressha (O Trem), recebe o prêmio jornalístico Tôo Nippô.

- Março: junta-se ao grupo que publica Kaihyô (O Leão Marinho).

Obras: Gyofukuki (Metamorfose), Omoide (Lembranças).

1934 (25 anos)

- Abril: publica parcialmente Ghost Written (Escritos por outrem) e Yônosuke no Kien (O Destino de Yônosuke) na revista Bungei Shunjû (Estações Literárias).

- Dezembro: publica, com os amigos, a revista Aoi Hana (Flor Azul), que finda no primeiro número.

Obras: Ha (Folhas); Sarumen Kaja (Cara de Macaco); Kare wa Mukashino Kare Nazaru (Ele Não é Mais o Mesmo Homem); Romanesku (Romanesco); Sange (Flores Despetaladas); Yônosuke no Kien (A Conversa de Yônosuke); Chansu (Chance); Gakuseigun (Os Estudantes).

1935 (26 anos)

- Fevereiro: Gyakko (Retrocesso) é publicado na revista Bungei (Arte Literária). Dazai interrompe seus estudos na Universidade Imperial de Tóquio, decidido a não dar continuidade aos estudos. Ao tomar conhecimento da reprovação nos exames para ingresso no Miyako Shinbun (Notícias da capital), ele tenta se enforcar na cidade de Kamakura.

- Abril: contrai peritonite após uma cirurgia emergencial de apendicite. É acometido também por problemas pulmonares. Drogas são prescritas para amenizar-Ihe a dor. Após a alta hospitalar, torna-se dependente das mesmas.

- Julho: muda-se com Hatsuyo para Funabashi a fim de se recuperar.

- Agosto: começa a corrida pelo primeiro prêmio literário Akutagawa. 
$\checkmark$ Obras: Dasu Gemaine (Das Gemaine); Dôke no Hana (Flores de Palhaço); Gangu (Brinquedos); Kawabata Yasunari E (Para Yasunari Kawabata); Kyokô no Haru (A Primavera Fictítia); Sôseiki (Gênesis); Gyakkô (Contra a Corrente).

1936 (27 anos)

- Fevereiro: busca apoio de Satô Haruo para a indicação ao prêmio Akutagawa. Dazai é hospitalizado em razão do vício ao barbitúrico, mas deixa o hospital sem receber alta. Implora aos amigos para the concederem empréstimos em dinheiro.

- Junho: é publicada a primeira coleção de contos Bannen (Últimos Anos).

- Julho: ao comemorar a publicação do livro, ele promove festas, excedendo-se nos vícios, e novamente o pulmão é afetado.

- Agosto: decide ir para as termas de Tanigawa a fim de se recuperar. Recebe a notícia de que novamente não fora o ganhador do prêmio Akutagawa.

- Setembro: em carta, fala aos seus amigos da intenção de se suicidar. Relata aos outros amigos sobre planos de se internar por dois anos no sanatório para cuidar da sua tuberculose.

- Outubro: em 13 de outubro, é internado pelos amigos no hospital para doentes mentais na cidade de Musashino. Ele é mantido lá até o dia 12 de novembro. Finalmente o vício é controlado, e de alguma maneira a sua saúde melhora. Tão logo recebe alta, começa a escrever Nijisseiki kishu (Sinaleiro do Século XX), mas por outro lado, poucos trabalhos foram escritos até meados de 1938.

$\checkmark$ Obras: Mesu ni Tsuite (Sobre a Mulher); Sarugashima (Ilha dos Macacos); Saruzuka (A Tumba do Macaco).

1937 (28 anos) 
- Março: toma conhecimento do adultério de Hatsuyo. Eles vão às termas de Minakami e tentam se suicidar, mas ambos sobrevivem. Eles retornam a Tóquio e se separam. A princípio, Hatsuyo vai para a casa de Ibuse e depois para a casa de seu tio.

- Maio: viaja com amigos e Ibuse por uma semana para Miyakejima.

- Julho: Hatsuyo retorna a Aomori com 30 ienes, dados por Dazai como um presente.

$\checkmark$ Obras: Nijisseiki Kishu (Sinaleiro do Século XX); Tôrô (Lanterna Mágica); Zakyô ni Arazu (Não Brinque); Kyokô no Hôkô (Vagando na Falsidade).

1938 (29 anos)

- Na primeira metade do ano, Dazai vive na indolência total. Ele consegue escrever pouca coisa.

- Setembro: Dazai é chamado por Ibuse para ir a Misaka. Passa os próximos dois meses no sopé do Monte Fuji e começa a escrever novamente. Nesse local, ele é apresentado a Ishihara Michiko. Em novembro, é feito o preparativo para o noivado.

- Novembro: deixa Misaka e se estabelece em Kôfu.

$\checkmark$ Obras: Mangan (Realização do Pedido); Matsu (A Espera); Ubasute (Abandono do Ancião Para a Morte); Hi no Tori (Pássaros de Fogo).

1939 (30 anos)

- Janeiro: com a intermediação de Ibuse, Dazai casa-se com Michiko. Eles alugam um apartamento em Kôfu.

- Abril: recebe o prêmio de 50 ienes pelo Ôgon Fûkei(Cenário Dourado).

- Maio: Viaja com sua mulher para Suwa.

- Junho: viaja com sua mulher, cunhada e sogra ao redor de Izu.

- Setembro: o casal se muda para uma casa alugada em Mitaka, nas cercanias de Tóquio. Lá, a empresa jornalística Tôo Nippô oferece um banquete para os escritores e artistas nascidos em Aomori, inclusive Dazai. 
Pela quarta vez recebe o prêmio Kitamura Tôkoku pelo conto Joseito (A Estudante).

- Setembro: começa a Segunda Guerra Mundial na Europa.

$\checkmark$ Obras: Ai to Bini Tsuite (Sobre Beleza e Amor); Bishôjo (Bela Jovem); Fugaku Hyakkei (Cem Visões do Monte Fuji); Hazakura no Mateki (O Assobio da Folha de Cerejeira); I Can Speak (Eu Posso Falar); Joseito (A Estudante); Ôgon Fûkei (Cenário Dourado); Bannen (Últimos Anos); Chikukendan (Animal Doméstico); Shûfûki (Registro de Vento Outonal); Zenzô o Omou (Lembranças de Zenzô); Oshare Dôji (A Criança Vaidosa); Hachijûhachiya (Oitenta e Oito Noites); Chikyûzu (Mapa do Mundo); Hifu to kokoro (Pele e Coração).

1940 (31 anos)

- Abril: organiza um banquete para comemorar a publicação do livro do amigo Yamagishi Gaishi.

- Julho: vai a Izu e começa a escrever o conto Tôkyô Hakkei (Oito Visões de Tóquio).

- Outono: faz palestra na Universidade Comercial de Tóquio e na Faculdade de Niigata. Logo depois, viaja para Ilha Sado.

$\checkmark$ Obras: Anitachi (Meus Irmãos); Hashire Merosu (Corra, Melos); Kakekomi Uttae (Eu Acuso); Onna no Kettô (Duelo de Mulheres); Zokutenshi (O Anjo Vulgar); Haru no Tôzoku (Ladrão de Primavera); Kojiki Gakusei (Estudante Pedinte); Kirigirisu (O Grilo); Sado (Sado); Aomori (Aomori); Goshogawara (Goshogawara); Kamome (A Gaivota); Ensaio: Konogoro (Esses Dias).

1941 (32 anos)

- Janeiro: viaja com a mulher para Izu.

- Fevereiro: viaja para Shizuoka a fim de dar início a Shin Hamuretto (Novo Hamlet).

- Abril: viaja para Kôfu para dar continuidade às suas escritas. 
- Junho: nasce a primeira filha, Sonoko. Começa a receber diversas cartas de Ôta Shizuko.

- Agosto: sob o conselho de Kita Yoshihiro, Dazai retorna à terra natal após dez anos. Lá, ele se encontra com a mãe e a avó.

- Setembro: encontra-se com Ôta Shizuko. A amizade entre ambos começa a se fortalecer.

- Novembro: é recrutado para o serviço militar, mas é dispensado devido à saúde frágil. Dazai despede-se de Ibuse, que segue para Singapura.

- 8 de dezembro: ataque dos japoneses a Pearl Harbor, que marca o início da Guerra do Pacífico contra os EUA.

$\checkmark$ Obras: Chiyojô (Jovem Talentosa); Fukusô ni Tsuite (Uma Questão de Aparência); Tôkyô Hakkei (Oito Visões de Tóquio); Shinkirô (Miragem); Shinrô (Os Recém-Casados); Jûnigatsu Yôka (Oito de Dezembro); Shin Hamuretto (O Novo Hamlet); Rôman Dôro (Lanternas de Romance); Seihintan (Conto de Pobreza Honesta).

1942 (33 anos)

- Nas termas perto de Kôfu, começa a escrever Seigi to Bishô (Justiça e Sorriso).

- Junho: é recrutado como reservista. De tempos em tempos, precisa fazer desempenho de autodefesa local.

- Verão: viaja para Kôfu e para os arredores de Hakone.

- Outubro: Hanabi (Fogos de Artifício) é censurado no limiar da publicação. Após a guerra, é publicado com o título de Hinode Mae (Antes do Amanhecer). A mãe adoece gravemente. Viaja para Kanagi com a mulher e a filha.

- Dezembro: viaja para Atami e arredores de Shizuoka com Ibuse a fim de escrever Udaijin Sanetomo (Sanetomo, Ministro da Direita). Sua mãe se encontra em estado crítico. Viaja sozinho a Kanagi para vê-la. No dia dez de dezembro, ela falece. 
$\checkmark$ Obras: Kikyôrai (Retorno para Tóquio); Seigi to Bishô (Justiça e Sorriso); Hinode Mae (Antes do Amanhecer); Hanabi (Fogos de Artifício); Chiisai Arubamu (Pequeno Álbum); Haji(Vergonha).

1943 (34 anos)

- Janeiro: viaja para Kanagi com a família para prestar homenagem póstuma à sua mãe.

- Março: finaliza Udaijin Sanetomo (Sanetomo, Ministro da Direita).

- Abril: ele é convidado para ser o mestre de cerimônias no casamento de um amigo.

- Novembro: Hibari no Koe (O Canto da Cotovia) não é publicado, com receio da censura. Aparece após a guerra sob o título de Pandorano Hako (Caixa de Pandora).

$\checkmark$ Obras: Kokyô (Terra Natal), Udaijin Sanetomo (Sanetomo, Ministro da Direita); Hibari no Koe (O Canto da Cotovia); Sakka no Techô (Agenda do Escritor).

1944 (35 anos)

- Janeiro: viaja para Atami a fim de escrever uma sinopse para o filme Kajitsu, baseado em sua história. Enquanto permanece em Atami, visita Shizuko próximo a Shimo Soga. Dazai recebe apoio financeiro governamental para escrever Sekibetsu (O Pesar da Separação).

- Maio e junho: com o patrocínio oferecido pela livraria Koyama, Dazai viaja durante três meses por Tsugaru (na província de Aomori) a fim de reunir material suficiente para concluir a obra de nome homônimo. Chegando à cidade natal, Dazai encontra velhos amigos e a ama-seca de infância, Take.

- Janeiro: leva sua mulher para Kôfu a fim de esperar o nascimento do seu segundo filho. Retorna para Mitaka após dez dias.

- Julho: finaliza o romance autobiográfico Tsugaru (Tsugaru).

- Agosto: nasce o filho Masaki. 
- Outubro: a sua ex-mulher, Hatsuyo, falece na China.

- Dezembro: Hibari no Koe (O canto da Cotovia) é destruído durante o bombardeio sobre a gráfica, mas a galé de imprensa é salva. Vai para a região de Sendai fazer pesquisa.

Obras: Kajitsu (Dias Felizes) e Tsugaru (Tsugaru)2 ; Yottsu no Kekkon (Quatro Casamentos); Yannuru Kana (Plano Falho); Suzumekko (Pequeno Pardal).

1945 (36 anos)

- Fevereiro: a obra Sekibetsu (O Pesar da Separação) é finalizada.

- Março: começa a escrever Otogizôshi (Fábulas). A fim de escapar dos intensos bombardeios sobre Tóquio, Dazai manda a família para Kôfu.

- Abril: a casa de Mitaka é danificada seriamente pelo ataque aéreo. Dazai a deixa sob os cuidados do amigo Koyama Kiyoshi e vai se juntar à família, em Kôfu.

- Junho: Otogizôshi (Fábulas) é finalizado.

- Julho: Kôfu também sofre bombardeios. Dazai entrega o manuscrito de Otogizôshi para Koyama Kiyoshi a fim de ser enviado para a editora Chikuma Shobô e depois volta para a terra natal. A viagem dura três dias. Aguarda o fim da guerra silenciosamente, lendo e cuidando da lavoura.

- Novembro: a irmã mais velha falece. Em carta, Dazai revela o crescente desespero acerca de sua vida "parasitária".

- 15 de agosto: rendição incondicional do Japão aos EUA, pondo fim à Segunda Grande Guerra.

$\checkmark$ Obras: Otogizôshi (Fábulas): Kachi Kachi Yama (A Montanha Crepitante); Kobutori Jiisan (O Removedor de Calombos); Urashima San (Senhor Urashima); Shitakiri Suzume (O Pardal da Lingua Cortada).

2 Dazai reduz a sua produção literária neste período devido à intensificação do bombardeio aéreo norte-americano. A vida cotidiana estava sendo muito difícil para todos. 
Shinshaku Shokoku Banashi (Novos "Relatos de Províncias"): Saruzuka (Tumba do Macaco; Hin no Iji (Sentimento do pobre); Dairiki (Força Bruta); Ningyo no Umi (Mar de Sereias); Hasan (Falência); Hadakagawa (Rio Despido); Giri (Dever); Nyozoku (A Jovem que Furta); Akai Taiko (O Tambor Vermelho); Suijin (Pessoa Sofisticada); Yûkyôkai (Lições de Divertimento); Yoshino Yama (Monte Yoshino).

Sekibetsu (O Pesar da Separação); Pandora no Hako (A Caixa de Pandora). Chikusei (O Bambu Azul).

1946 (37 anos)

- Fevereiro: participa da discussão em mesa-redonda em Aomori e realiza palestras em colégios. Nesse ínterim, corresponde-se com Ôta Shizuko.

- Abril: o irmão mais velho, Bunji, é eleito para a Casa dos Representantes. Koshino Take vem visitá-lo, vinda de Komori.

- Maio: o ator Akutagawa Hiroshi, filho do escritor Akutagawa Ryûnosuke, faz uma visita de dois dias a Dazai.

- Julho: falecimento da avó.

- Novembro: retorna com a mulher e os filhos para a casa de Mitaka, nos arredores de Tóquio. Participa de uma mesa redonda com os escritores Sakaguchi Ango e Ôda Sakunosuke.

- Dezembro: aluga um escritório nas redondezas. Sai toda tarde para se embebedar. O ensaio para a peça teatral Fuyu no Hanabi (Fogos de Artifícios de Inverno) é fechado pelas autoridades da ocupação.

Obras: Fuyu no Hanabi (Fogos de Artifícios de Inverno); Hakumei (Luzes da Aurora); Haru no Kareha (Folhas Secas de Primavera); Jûgonenkan (Durante Quinze Anos); Kahei (Dinheiro); Kunô no Nenkan (O Almanaque da Dor); Merii Kurisumasu (Feliz Natal); Niwa (O Quintal); Oya to Iu Niji (Duas Letras que Significam "Pais"); Shin'yû Kôkan (Meu Melhor Amigo); Uso (Mentira); Suisen (Narcisos); Tazunebito (Pessoas Desaparecidas); Ningen (O Ser Humano); Danjô Dôken (Direito de Igualdade Feminina); Jorui (Mulheres); Watari Dori (Pássaros Migratórios). 
1947 (38 anos)

- Fevereiro: passa vários dias com Ôta Shizuko na cidade de Shimo Soga.

- Março: começa a escrever Shayô (Pôr-do-Sol) nas proximidades da cidade de Mitohama. Retorna para Tóquio. Visita Shizuko novamente. A sua mulher toma conhecimento do caso amoroso. Encontra Yamazaki Tomie. Nesse ano, nasce a segunda filha do casal, Sotoko. Ele se muda para o escritório perto do apartamento de Yamazaki Tomie.

- Maio: Haruno Kareha (Folhas Secas de Primavera) é protagonizado em forma de peça pela emissora de rádio NHK (Nippon Hôsô Kyoku). Ôta Shizuko e o irmão vão à casa de Dazai discutir sobre a gravidez da mesma. Dazai leva-os para beber em um bar, onde encontram com Tomie, a nova amante de Dazai.

- Junho: o romance Shayô (Pôr-do-Sol) é concluído.

- Julho: Tomie ouve a notícia oficial da morte do seu marido. Dazai relata aos amigos sobre o pacto que fizera de morrer com Tomie no decorrer do ano.

- Agosto: Tomie recebe em seu apartamento a visita de Ibuse Masuji, mentor de Dazai, Usui Yoshimi e o proprietário da Editora Chikuma Shobô, Furuta Akira. Eles se reuniram lá para discutir sobre a publicação da coletânea de Ibuse. Ficou estabelecido que Dazai seria o editor geral da publicação. Nesse ano, a saúde de Dazai se deteriorou visivelmente. Ele ocupava o apartamento de Tomie como escritório e raramente aparecia em casa.

- Setembro: vai para Resort Atami com Ima Harube e Tomie.

- Novembro: a livraria Yakumei Shoten contrata Dazai para publicar os trabalhos e coletâneas. Nasce a filha de Shizuko, Haruko. Dazai dá o nome ao bebê. Nessa época, a saúde de Dazai piora, e ele começa a tossir sangue.

- Dezembro: overdose acidental de sonífero. Recobra o sentido, mas a sua saúde está extremamente debilitada. 
$\checkmark$ Obras: Asa (Manhã); Chichi (Meu Pai); Haha (Minha Mãe); Kyôgen no Kami (O Deus da Farsa); Osan (A Empregada); Tokatonton (O Som da Martelada); Viyon no Tsuma (A Esposa de Villon); Yukino Yô no Hanashi (História de Noite de Nevasca); Shayô (Pôr-do-Sol); Megami (Deusa); Fuosforecensu (Fosforescência).

1948 (39 anos)

- Fevereiro: a peça Haruno Kareha (Folha Seca de Primavera) é encenada em Tokyo. A cunhada falece. Enquanto sua mulher está fora, cuidando do funeral da mesma, Dazai traz para a sua casa Tomie, e sua mulher toma conhecimento do caso.

- Março: viaja para Atami com Tomie. Começa a escrever Ningen Shikkaku (Desqualificado Como Ser Humano). Com o patrocínio do jornal Asahi Shimbun, começa a escrever a série em forma de novela Guddobai (Adeus). Tem início a publicação de Nyoze Gamon (Palavras da Sagrada Escritura). Recebe com irritação a crítica feita pelo escritor Shiga Naoya sobre Nyoze Gamon (Palavras da Sagrada Escritura).

- Abril: Ibuse aconselha Dazai a interromper Nyoze Gamon (Palavras da Sagrada Escritura). É publicado o primeiro volume de Dazai Osamu Zenshû (Obras Completas de Dazai Osamu) pela livraria Yakumo. Ele viaja em companhia de Tomie para Ômiya. Estabelece-se por lá até meados de maio, finalizando Ningen Shikkaku (Desqualificado Como Ser Humano).

- Maio: começa a escrever Guddobai (Adeus). Dazai sofre hemorragia pulmonar.

- Junho: é publicada a primeira parte de Ningen Shikkaku (Desqualificado Como Ser Humano). Conclusão dos primeiros capítulos de Guddobai (Adeus).

- 13 de junho: Dazai e Tomie desaparecem no meio da noite, deixando um bilhete de despedida para amigos. Os jornais dão conta do desaparecimento somente no dia 15 de junho. 0 canal de Tamagawa é revirado pelas equipes de resgate a fim de encontrá-los. 
- Na manhã do dia 19 de junho, dois corpos são encontrados no canal, justamente no dia do aniversário de 39 anos do escritor, (pela contagem japonesa, 40 anos).

- 21 de junho: funeral de Dazai. No dia 18 de julho, suas cinzas são depositadas no templo Zenrinji, em Mitaka.

- 25 de julho: Ningen Shikkaku (Desqualificado Como Ser Humano) é publicado pela Editora Chikuma Shobô.

$\checkmark$ Obras: Bidanshi to Tabako (O Belo Homem e o Cigarro); Guddobai (Adeus) *inacabada; Hannin (O Criminoso); Katei no Kôfuku (A Felicidade do Lar); Kyôo Fujin (A Dama da Diversão); Ningen Shikkaku (Desqualificado Como Ser Humano); Nyoze Gamon (Palavras da Sagrada Escritura); Ôtô (Cerejeiras); Bisan.

\section{Cronologia das Obras de Dazai Osamu}

1922 - Ensaio: Boku no Yôji (Minha Infância)

1928 - Mugen Naraku (Inferno sem Fim)

Aware ga (Pobre Mariposa).

1929 - Jinushi Ichidai (A Vida do Senhor das Terras)

1932 - Ressha (O Trem)

1933 - Gyofukuki (Metamorfose)

Omoide (Lembranças)

1934 - Ha (Folhas)

Sarumen Kaja (Cara de Macaco)

Karewa Mukashino Kare Nazaru (Ele é o Mesmo Homem)

Romanesku (Romanesco)

Sange (Flores Despetaladas) 
Yônosuke no Kien (Conversa de Yônosuke)

Chansu (Chance)

Gakuseigun (Os Estudantes)

1935 - Dasu Gemaine (Das Gemaine)

Dôkeno Hana (Flores de Palhaço)

Gangu (Brinquedos)

Kawabata Yasunari e (Para Yasunari Kawabata).

Kyokô no Haru (A primavera fictícia)

Sôseiki (Gênesis)

Gyakkô (Contra a Corrente)

1936 - Mesuni Tsuite (Sobre a Mulher)

Sarugashima (Ilha dos Macacos)

1937 - Kyokô no Hôkô (Vagando na Falsidade))

Nijusseiki Kishu (Sinaleiro do Século XX)

Tôrô (Lanterna Mágica)

Zakyôni Arazu (Não Brinque)

1938 - Mangan (Realização do Pedido)

Matsu (A Espera)

Ubasute (Abandono do Ancião para a Morte)

Hino tori (Pássaros de Fogo)

1939 - Aito Bini Tsuite (Sobre Beleza e Amor)

Bishôjo (Bela Jovem)

Fugaku Hyakkei (Cem Visões do Monte Fuji)

Hazakurano Mateki (O Assobio da Folha de Cerejeira)

I Can Speak (Eu Posso Falar)

Joseito (A Estudante)

Ôgon Fûkei (Cenário Dourado)

Bannen (Ultimos Anos) 
Chikukendan (Animal Doméstico)

Shûfûki (Registro de Vento Outonal)

Zenzôo Omou (Lembranças de Zenzô)

Oshare Dôji (A Criança Vaidosa)

Hachijûhachiya (Oitenta e Oito Noites)

Hifu to Kokoro (Pele e Coração)

Chikyûzu (Mapa do Mundo)

1940 - Anitachi (Meus irmãos)

Hashire Merosu (Corra, Melos)

Kaketomi Uttae (Eu Acuso)

Onnano Kettô (Duelo de Mulheres)

Zokutenshi (O Anjo Vulgar)

Haruno Tôzoku (Ladrão de Primavera)

Kojiki Gakusei (Estudante Pedinte)

Sado (Sado)

Kamome (A Gaivota)

Kirigirisu (O Grilo)

Aomori (Aomori)

Goshogawara (Goshogawara)

Ensaio: Konogoro (Esses Dias)

1941 - Chiyojô (Jovem Talentoso)

Fukusôni Tsuite (Uma Questão de Aparência)

Tôkyô Hakkei (Oito Visões de Tóquio)

Shinkirô (Miragem)

Shinrô (Os Recém-casados)

Jûnigatsu Yôka (Oito de Dezembro)

Shin Hamuretto (O Novo Hamlet)

Rôman Dôro (Lanternas de Romance) 
Seihintan (Conto de Pobreza Honesta)

1942 - Kikyôrai (Retorno para Tóquio)

Seigito Bishô (Justiça e Sorriso)

Hinode Mae (Antes do Amanhecer)

Hanabi (Fogos de Artifício)

Chiisai Arubamu (Pequeno Álbum)

Haji (Vergonha)

1943 - Kokyô (Terra Natal)

Udaijin Sanetomo (Sanetomo, Ministro da Direita)

Hibarino Koe (O Canto da Cotovia)

Sakka no Techô (Agenda do Escritor)

1944 - Tsugaru (Tsugaru)

Kajitsu (Dias Felizes)

Yottsu no Kekkon (Quatro Casamentos)

Yannuru Kana (Plano Falho)

Suzumekko (O Pequeno Pardal)

1945 - Otogizôshi (Fábulas): Kachi Kachi Yama (A Montanha Crepitante); Kobutori Jiisan (O Removedor de Calombos); Urashima San (Senhor Urashima); Shitakiri Suzume (O Pardal da Lingua Cortada).

Shinshaku Shokoku Banashi (Novos Relatos de Províncias Reinterpretados): Saruzuka (Tumba do Macaco); Hin no Iji (Sentimento do Pobre); Dairiki (Força Bruta); Ningyo no Umi (Mar de Sereias); Hasan (Falência); Hadakagawa (Rio Despido); Giri (Dever); Nyozoku (A Jovem que Furta); Akai Taiko (O Tambor Vermelho); Suijin (Pessoa Sofisticada); Yûkyôkai (Lições de Divertimento); Yoshinoyama (Monte Yoshio).

Sekibetsu (O Pesar da Separação)

Pandora no Hako (A Caixa de Pandora)

Chikusei (Bambu Azul)

1946 - Fuyuno Hanabi (Fogos de Artifícios de Inverno) 
Hakumei (Luzes da Aurora)

Haruno Kare Há (Folhas Secas de Primavera)

Jûgonenkan (Durante Quinze Anos)

Kahei (Dinheiro)

Kunono Nenkan (O Almanaque da Dor)

Merii Kurisumasu (Feliz Natal)

Niwa (O Quintal)

Oyato Iu Niji (Duas Letras que Significam Pais)

Shin'yû Kôkan (Meu Melhor Amigo)

Uso (Mentira)

Ningen (O ser humano)

Suisen (Narcisos)

Tazunebito (Pessoas Desaparecidas)

Danjô Dôken (Direito de Igualdade Feminina)

Jorui (Mulheres)

Watari Dori (Pássaros Migratórios)

1947 - Asa (Manhã)

Chichi (Meu pai)

Haha (Minha Mãe)

Kyôgenno Kami (O Deus da Farsa)

Osan (A Empregada)

Tokatonton (O Som da Martelada)

Viyon no Tsuma (A Esposa de Villon)

Yukino Yono Hanashi (História de Noite de Nevasca)

Shayô (Pôr-do-Sol)

Megami (Deusa)

Fuosforecensu (Fosforescência)

Bisan 


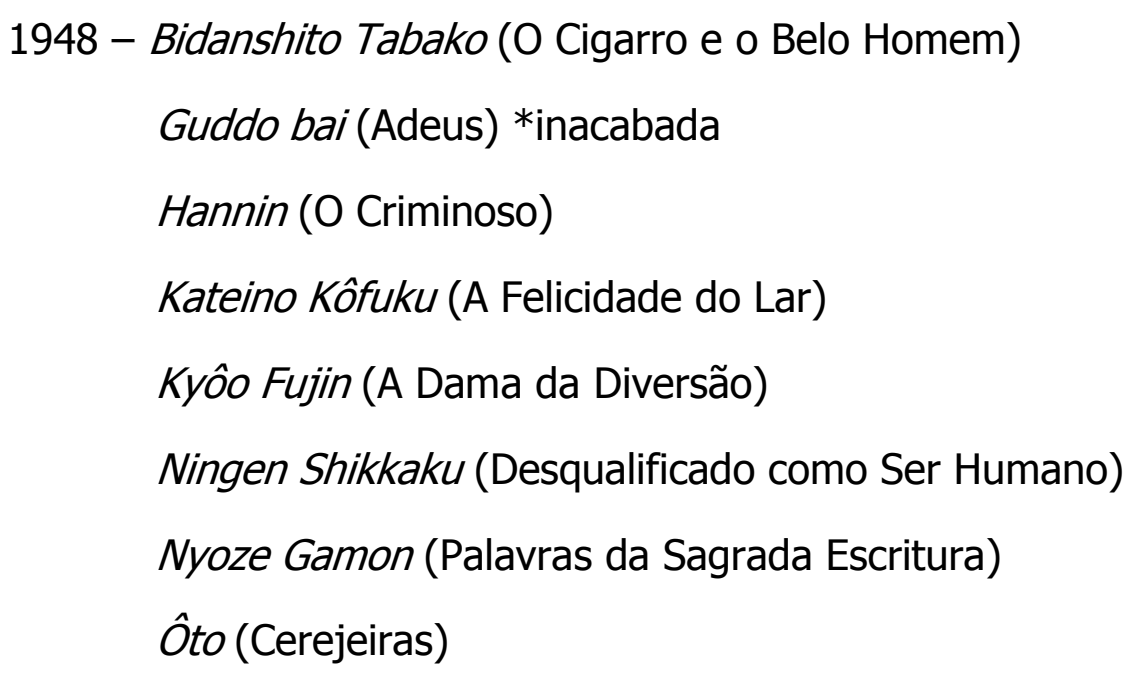




\section{Apêndice B \\ Tradução da Obra Shayô (Pôr-do-Sol)}

Por: Hiroko Hashimoto da Silva

hiroko.hashi@hotmail.com

\section{Referência:}

DAZAI, Osamu. Shayô (Pôr do Sol). In: ITO, Sei et al. (Org.). Dazai Osamu shû. (Coletânea Dazai Osamu). Comentários Kôda Susumu e Okuno Takeo. Tôkyô, JP: Shûeisha, 1957. p. 07-111 e 384-386. Nihon Bungaku Zenshû, 70 (Coleção completa da Literatura Japonesa, v. 70).

\section{Capítulo I}

De manhã, na sala de jantar, ao sorver uma colher de sopa, mamãe soltou uma exclamação:

$$
\begin{aligned}
& \text { - Oh! } \\
& \text {-É cabelo? - indaguei, pensando ter algo desagradável na sopa. } \\
& \text { - Não é nada. }
\end{aligned}
$$

Como se não houvesse nada, mamãe tornou a levar a sopa à boca, virando levemente o seu rosto e, através da janela da copa, ficou a observar as cerejeiras floridas. Ainda com o rosto virado, ela entornou a sopa rapidamente entre seus delicados lábios - essa descrição não é nada exagerada ao falar de mamãe. O seu modo de se servir às refeições difere completamente do apresentado nas revistas femininas de boas maneiras.

Uma vez, enquanto bebia, meu irmão Naoji, disse-me

- Fique sabendo que não é pelo título que alguém se torna nobre. Há nobres de fato que, mesmo sem título, já nascem com essa virtude e outros, como no nosso caso, que, embora portadores de título estamos mais próximo dos excluídos. O Iwajima, por exemplo (citou o nome de conde, um colega seu de escola), aquele cara era mais vulgar que o funcionário de um bordel de Shinjuku ${ }^{3}$. Ainda outro dia, o Yanai (também colega de escola, filho de um visconde), na cerimônia de casamento do irmão, vestiu fraque aquele idiota! Não tinha necessidade para tanto. Bem, isso ainda vá lá, mas na hora do discurso, ele utilizou uma expressão exageradamente

3 O bordel de Shinjuku funcionou na quadra 2 do bairro de Shinjuku até a proibição total de prostituição no mês de abril de 1958. 
polida e estranha, que me causou náuseas. A postura pode-se traduzir em vulgaridade, nada tem a ver com distinção. Havia nos arredores de Hongo, uma tabuleta com a inscrição "Pensão de Alta Classe", mas na realidade, esses nobres, na maioria dos casos, pode-se dizer, serem "mendigos de alta classe". O verdadeiro nobre não posa como o desajeitado Iwajima. Dentro do nosso círculo familiar, o verdadeiramente nobre talvez somente a mamãe. Ela, sim, é uma legítima nobre! Impossível ser como ela.

No nosso caso, ao tomarmos sopa, inclinamos um pouco o rosto sobre o prato, pegamos segurando a colher lateralmente e depois a levamos à boca. Contudo, no caso da mamãe, ela repousa os dedos da mão esquerda suavemente sobre a mesa, sem inclinar o corpo. Com o rosto ereto, sem quase olhar para o prato, pega a sopa, segurando a colher lateralmente, e com um gesto tão leve e ágil que lembra o vôo da andorinha, leva a colher perpendicularmente à boca, e deixa deslizá-la entre os lábios, pela ponta. E, depois, num gesto inocente, observa ao redor, manejando a colher como uma pequena asa, sem entornar uma gota do líquido, sem nenhum som do sorver ou do prato. Esse procedimento não seria o que recomenda a etiqueta de boas maneiras à mesa, mas, aos meus olhos, era muito gracioso e me parecia correto. De fato, a sopa torna-se mais deliciosa quando você a toma pela ponta da colher, do que pegá-la lateralmente e levá-la à boca. Todavia, como diz o Naoji, eu não passo de uma mendiga de classe alta, e não consigo manejar a colher com desenvoltura feito mamãe, com classe e leveza. Como sou um caso perdido, desisti de imitá-la e debruço-me sobre o prato para me servir, seguindo o modo sombrio ditado pela etiqueta de boas maneiras.

Não é só no ato de tomar sopa que mamãe transgride as regras de boa etiqueta. Ao se servir de carne, ela pega o garfo e a faca, fatia-a toda primeiro e depois deixa de lado a faca, transferindo o garfo para a mão direita. Então, vai-se servindo dos pedaços fatiados, espetando-os com o garfo, saboreando-os calmamente e se deliciando com a iguaria. $\mathrm{O}$ mesmo acontece com o pedaço de frango. Enquanto nós padecemos em não provocar ruído de talheres sobre o prato ao separar os ossos da carne, mamãe, sem escrúpulos, pega-o com a ponta dos dedos e separa a carne dos ossos com os dentes. Esse gesto grosseiro, em se tratando de mamãe, torna-se gracioso e estranhamente erótico. Com certeza, a verdadeira nobreza difere da falsa. Não é somente o caso de ela pegar o frango com as mãos. Mamãe pega também com as mãos os acompanhamentos do lanche, como os presuntos e salsichas.

- Você sabe por que é que o omusubi ${ }^{4}$ é tão gostoso? É porque é feito com a mão humana, comprimido na palma da mão. - ela me disse certa vez. Na realidade, se nós comêssemos com a mão, seria delicioso, penso algumas vezes, mas como uma mendiga de classe alta que sou, se eu passasse a comer com as mãos, pareceria uma verdadeira mendiga, então contenho-me para não me expor a tal baixeza.

Até meu irmão Naoji diz que é impossível ser como mamãe. É difícil imitá-la, o que me leva ao desespero. Certa noite, no começo do outono, no quintal ao fundo da casa em Nishikata, eu estava com ela no quiosque perto do lago, observando o luar, conversando e rindo sobre a diferença entre os preparativos de casamento da

4 Bolinho de arroz comprimido na palma da mão. 
raposa e da rata. De repente, mamãe levantou-se e dirigiu-se ao fundo do canteiro de lespedezas e, depois, entre as flores brancas, mostrou seu rosto alvo, com um sorriso maroto na face, e indagou-me:

- Kazuko, adivinhe o que eu estou fazendo agora?

- Colhendo flores.

Mamãe riu baixinho e disse:

- Estou urinando.

Espantei-me por ela não estar agachada, e senti que havia naquilo algo realmente adorável que eu jamais conseguiria imitar.

Desviei um pouco o assunto do caso da sopa da manhã, mas outro dia, li certo livro sobre o reinado de Luís XIV ${ }^{5}$. Naquela época, era comum as damas da corte urinarem nos jardins do palácio, ou nos cantos dos corredores. Essa inocência da mamãe me encantou, e me fez pensar que ela seria a última remanescente dessas damas da corte.

Naquela manhã, ao sorver uma colherada de sopa, quando mamãe soltou uma leve exclamação, perguntei se haveria um fio de cabelo. Respondeu que não.

-- Está muito salgada?

Eu havia feito um creme de ervilhas, das enlatadas distribuídas dias antes pelos americanos. Como não me considero boa cozinheira, havia feito aquela pergunta, receosa.

\section{- Está muito bem feita!}

Mamãe falou seriamente e, ao tomá-la, pegou o bolinho de arroz envolto em nori ${ }^{6}$ e serviu-se.

Desde pequena, não tenho apetite na refeição matinal, é lá pelas dez horas, que me dá fome. Àquela hora da manhã, consegui me forçar a tomar a sopa, coloquei o bolinho de arroz no prato, amassei-o com o ohashi ${ }^{7}$ e coloquei-o na boca. Queria imitar mamãe quando ela tomava sopa: posicionei o ohashi perpendicularmente à boca e, como um pássaro alimentando o filhote, empurrei o bolo de arroz garganta abaixo. Enquanto eu me demorava a comer daquela forma mamãe já havia terminado sua refeição. Levantou-se e foi postar-se na parede a fim de tomar o sol da manhã. Enquanto ela se banhava nos raios de sol, junto à parede, observava silenciosamente o meu modo de me servir à mesa e disse:

- Kazuko, você ainda não se alimenta bem. Você deve se esforçar para que a refeição matinal seja a mais gostosa.

- E a senhora? Acha gostosa?

- Deliciosa. Eu já não estou mais doente.

- Eu também não estou doente.

\footnotetext{
${ }^{5}$ Luís XIV (1638-1715) foi rei da França. Implantou o sistema da lei monárquica, presenciou a Idade de Ouro da França, difundiu a cultura da residência palaciana e teve como ícone o Palácio de Versailles. Foi executado no século XVI (1751-1793), na Revolução Francesa.

${ }^{6}$ Folha feita de pasta de algas para enrolar o sushi.

${ }^{7}$ Dois palitos que os orientais utilizam para comer.
} 
- Não, não, você não se alimenta bem.

Mamãe sorriu melancolicamente e meneou a cabeça.

Cinco anos atrás, fiquei acamada devido a uma doença pulmonar, que eu sabia ter sido causada pelo meu egoísmo. A doença que acometeu mamãe outro dia, porém, foi preocupante e entristeceu-nos. Mesmo assim, mamãe se preocupa mais com a minha saúde do que com a dela.

-Oh! - Exclamei.

- O que foi?

Desta feita, foi ela quem me perguntou. Olhamos uma para a outra e Ihe sorri, como se tivéssemos tido o mesmo pensamento e ela também me retribuiu.

Quando somos assaltadas por um sentimento de extrema vergonha, geralmente soltamos esse leve clamor: "Oh!" Em meu peito, naquele instante, emergiu, com toda a nitidez, a imagem de seis anos atrás, na ocasião do meu divórcio, coisa insuportável, e, sem pensar, soltei um "Oh!". Mas, no caso da mamãe, o que seria? Será que ela escondia um segredo vergonhoso como o do meu passado? Se não fosse isso, o que seria?

- Agora há pouco, a senhora também acabou de se lembrar de algo, não é? Que tipo de coisa foi?

- Ah, eu me esqueci.

-É sobre mim?

- Não.

-É sobre Naoji?

$-\operatorname{Sim} . .$.

Ela começou a falar, inclinou a cabeça e emendou:

-É possível.

Naoji cursava a universidade quando fora convocado para servir nas ilhas do sul; as notícias sobre ele se interromperam. Mesmo com o fim da guerra, o seu paradeiro era ignorado. Mamãe vive dizendo que se conformou em não vê-lo vivo nunca mais, no entanto, eu nunca fiz essa projeção agourenta sobre sua volta, e sempre tive um fio de esperanças de tornar a vê-lo.

--- Pensei que tinha me conformado com o desaparecimento de Naoji, mas enquanto saboreava a sopa, lembrei-me dele e senti uma dor insuportável. Eu deveria tê-lo tratado com mais carinho.

Desde o ingresso no colégio, Naoji tornara-se aficionado pela literatura e começou uma vida praticamente indolente, causando imensurável preocupação para mamãe. Mesmo assim, ela se lembra de Naoji, entre uma colherada e outra da sopa, e exclama "Oh!". Eu enfiei o arroz garganta abaixo e fiquei com os olhos marejados de lágrimas.

- Não se preocupe. Naoji está bem. Gente ruim como o Naoji é difícil de morrer, viu? As pessoas que morrem são gentis, belas e boas. Um sujeito feito Naoji não morre nem a paulada. 

forma.

- Ah, então, você, Kazuko, falecerá prematuramente. - E caçoava-me dessa

- Ora, por quê? Eu, como encarnação do mal, posso garantir até os oitenta anos.

- Ah, é? Se for assim, eu posso viver até os noventa, não é?

-É...

Comecei a responder e fiquei um pouco embaraçada. Os maus têm vida longa. As pessoas belas morrem cedo. Mamãe é bela. No entanto, eu quero que ela tenha vida longa. Fiquei extremamente confusa.

- Como a senhora é má, hein?

Ao dizer isso, meus lábios começaram a tremer e lágrimas transbordaram dos meus olhos.

Será que devo falar sobre as cobras? Numa tarde de uns quatro ou cinco dias antes, as crianças da redondeza trouxeram dez ovos de serpentes que foram encontrados no bambuzal que serve de cerca no quintal.

- São ovos de cobra peçonhenta - elas insistiram.

Eu conjecturei que, caso nascessem aquelas dez cobras, eu não poderia mais andar pelo quintal, então decidi:

- Vamos queimá-los!

As crianças se exaltaram e me seguiram.

Amontoei folhas e gravetos perto do bambuzal, acendi o fogo,e lancei ali os ovos um a um. Eles eram difíceis de queimar. As crianças juntaram mais folhas secas e gravetos para aumentar a labareda e, mesmo assim, os ovos não queimaram. sorridente:

A filha do lavrador que morava no pé da colina perguntou-nos meio

- O que vocês estão fazendo?

- Estamos queimando ovos de cobra, tenho pavor delas.

- De que tamanhos são?

- São do tamanho de ovos de codorna, bem branquinhos.

- Ah, então são ovos de cobra comum. Não são de serpente peçonhenta. Os ovos dificilmente se queimam, sabia?

A mocinha riu, como se achasse graça, e foi embora.

Durante trinta minutos, deixei os ovos dentro do fogo e, mesmo assim, eles não queimaram. Por isso mandei as crianças pegarem-nos de dentro do fogo e enterrarem-nos ao pé da ameixeira. Juntei umas pedrinhas e fiz um túmulo.

- Bem, crianças, vamos todos rezar.

Enquanto eu rezava agachada, as crianças também se puseram de joelhos atrás de mim. Terminada a cerimônia, despedi-me delas, e comecei a subir 
vagarosamente as escadarias de pedra. Em seu topo, junto ao caramanchão de glicínias, estava mamãe, que me disse:

- Que crueldade você cometeu!

- Pensei que fossem ovos de serpentes peçonhentas, mas, no fim, não eram. Para me remediar, fiz o devido sepultamento, por isso não há problema.

Disse isso, mas não achei bom que mamãe tivesse visto.

Com certeza, mamãe não é uma pessoa supersticiosa, mas, dez anos antes, desde a morte de papai, na casa de Nishikata, começou a temer as cobras. Um pouco antes do seu falecimento, mamãe viu caído em sua cabeceira algo que pensou ser um cordão preto e foi pegá-lo, mas era uma cobra. Ela saiu rastejando pelo corredor e desapareceu em algum lugar. Somente a mamãe e o tio Wada foram as pessoas que presenciaram esse incidente. Os dois se entreolharam, mas para não tumultuarem o quarto em que papai agonizava, mantiveram-se calados. Nós estávamos presentes também no local, mas não tomamos conhecimento de nada. Entretanto, ao entardecer do dia do falecimento do papai, eu havia realmente visto cobras em todas as árvores próximas ao lago.

Hoje sou uma "titia" de vinte e nove anos, portanto, dez anos antes eu estava com dezenove anos. Como já não criança, o acontecimento de dez anos atrás se fixou claramente na minha memória, não há engano. Quando eu saí para o quintal em direção ao lago, a fim de colher flores para ofertar no sepultamento de papai, parei junto à azaléia na margem do lago e deparei com uma cobra enrolada na extremidade do galho. Levei um pequeno susto e fui tentar pegar o galho de rosas quérrias, mas, nele também havia uma cobra enrolada. No jasmim-do-imperador, ao lado dele, também havia uma cobra; no bordo japonês, na giesta, na glicínia, e também na cerejeira. Em todas as plantas, sem exceção, havia cobras enroladas por todo lado. Todavia, a mim não me amedrontavam tanto. Nisso veio-me à mente que, como eu, as cobras também estavam tristes pelo passamento do papai e elas saíram das suas tocas a fim de se despedir do morto. Notifiquei mamãe sobre a aparição das serpentes, mas ela não se manifestou, apenas inclinou a cabeça e ficou pensativa, sem nada comentar.

$\mathrm{Na}$ verdade, foi a partir desses dois incidentes que mamãe começou a ter aversão a cobras. Mais que aversão, é antes veneração ou temor, um temor reverente.

Achei que ao ser surpreendida por mamãe, quando queimava os ovos da serpente, tivesse provocado nela um sentimento de mau presságio. Nada me dissuadia de que aquele meu ato impensado desencadeara uma maldição na mamãe. Passei dias angustiantes, sem poder esquecer o fato. Dia após dia, minha preocupação foi crescendo. Depois de tudo, naquela manhã, na sala de jantar, deixei escapar aquela tolice de que as pessoas belas morrem prematuramente. Acabei caindo em prantos. Após o café da manhã, enquanto eu arrumava a mesa, tive um mau pressentimento de que, no fundo do meu peito, habitava uma cobra nojenta, que estava prestes a abreviar a vida da mamãe. Ai, esse sentimento era insuportável.

$E$, depois, naquele dia, vi no quintal uma cobra. Como o dia estava lindo e claro, após o término dos afazeres domésticos, carreguei a cadeira de vime até o gramado e pensei em tricotar ali mesmo. Logo vi uma cobra ao pé do bambuzal, 
junto às pedras. Ai que desgosto! - foi o que passou na minha mente. Voltei com a cadeira para a varanda, sentei-me e comecei a tricotar. À tarde, pensei em pegar o álbum de pinturas de Laurencin ${ }^{8}$ que fica na coleção de livros guardada no fundo do salão do quintal, quando vi, sobre a relva, uma cobra a deslizar lentamente. Era a mesma da manhã, delgada e elegante. É fêmea - pensei. Ela atravessou silenciosamente o gramado e, tendo chegado à sombra da roseira silvestre, parou, ergueu a cabeça e tremulou sua língua, como se fossem chamas. Parecia estar contemplando os arredores. Passado algum tempo, a cobra deixou pender a cabeça e se enrolou languidamente. Tive a impressão de que se tratava apenas de uma linda cobra. Depois, fui ao salão à procura do álbum e, na volta, espiei o local onde minutos antes estivera a cobra, mas ela já havia sumido.

Quase ao entardecer, ao tomar chá com a mamãe na sala chinesa e espiar o quintal, havia, na escadaria de pedra, uma cobra idêntica à da aparição matutina. Ela estava serena, estendida no terceiro degrau. Mamãe também a viu.

- E aquela cobra...?

Mal acabou de dizer isso, veio em minha direção, pegou a minha mão e se levantou, ficando estática. Ao ouvi-la, de repente lembrei-me do incidente e deixei escapar:

- Os ovos seriam dela?

-É, com certeza. - A voz da mamãe soou meio rouca.

Nós nos demos as mãos com a respiração presa e muda, e ficamos olhando para a cobra. Ela, que estava enrolada languidamente sobre a pedra, começou a se mover lentamente, atravessou o degrau de pedra e se esgueirou entre as folhagens de íris.

- Ela estava a rondar o jardim desde a manhã. - Disse em voz baixa, e mamãe, suspirando, deixou-se prostrar na cadeira, dizendo em voz melancólica:

- Deve ser. Coitada, está à procura dos ovos.

Sorri, sem jeito.

O raio de sol do entardecer batia no rosto da mamãe, o brilho dos seus olhos tinha uma cor azulada, sua feição estava carregada de leve irritação: era extremamente bela. E, depois, pensei comigo mesma: "Ah, o rosto triste da mamãe tem semelhança como a daquela cobra de agora há pouco. Há uma víbora que habita o meu peito e essa víbora será capaz, de um dia, matar a cobra mãe... não sei por que tive esse mau presságio..." aflita.

Coloquei a mão sobre o seu delicado ombro e senti-me inexplicavelmente

\footnotetext{
${ }^{8}$ Marie Laurencin (1885-1956), pintora e poetisa francesa explorou os temas da feminilidade e modos de representação feminina. Pintava retratos líricos de reparigas em cenários atrativos. O seu estilo linear e conciso, bem como a tendência para reduzir os rostos a uma simplicidade quase esquemática, reflete a influência das gravuras japonesas. Ela foi uma das poucas mulheres associadas aos cubistas parisienses, mas o seu trabalho manteve-se, sobretudo decorativo, apesar de refletir o tipo de estilização e de bidimensionalidade do espaço característicos daquele movimento.
} 
No início de dezembro, no ano em que o Japão se rendeu incondicionalmente, abandonamos a casa de Nishikata, em Tóquio, e mudamos para Izu, numa casa de campo em estilo chinês. Desde o passamento do papai, quem administrava as nossas finanças era o tio Wada. Era o irmão mais novo de mamãe e, também, único parente vivo. Com o fim da guerra, o mundo se transformou e parece que ele lhe disse que não havia outro jeito senão vender a casa, dispensar as empregadas e comprar uma casa nova em algum lugar do interior, onde mamãe e eu pudéssemos viver despreocupadamente. Mamãe, que, em matéria de dinheiro, entendia menos que uma criança, deixara tudo por conta do meu tio.

Em fins de novembro, chegou uma carta expressa enviada pelo tio Wada, dizia haver uma casa de campo à venda, pertencente ao Visconde Kawata localizada junto à estrada de ferro de Sunzu'. A casa ficava numa colina, possuía uma bela vista panorâmica e uma horta com cerca de cem metros quadrados. A região era famosa pelas flores de ameixeiras e o clima era cálido no inverno e ameno no verão. Uma vez residindo lá, ele achava que gostaríamos do lugar. Havendo a necessidade de negociar a casa com a outra parte, pedia a presença de mamãe no escritório dele em Ginza.

- A senhora vai? - perguntei-lhe.

- Pois é, eu tinha feito o pedido a ele. - respondeu sorrindo com profunda melancolia.

No dia seguinte, pediu ao antigo motorista, o Sr. Matsuyama, que a levasse até Ginza. Eles partiram logo depois do almoço e regressaram perto das oito horas da noite.

Mamãe entrou no meu quarto e colocou a sua mão sobre a cadeira, e sentouse como que desabando e disse:

- Pronto, está resolvido.

- Resolvido o quê?

- Tudo.

- Mas...

Assustada, perguntei-lhe:

- Como resolveu tudo, se a senhora nem viu a casa e não sabe como ela é?

Mamãe apoiou um dos cotovelos sobre a mesa e, colocando levemente a mão na testa, deu breve suspiro e disse:

- Bem, se o seu tio Wada diz que o local é bom, achei que podia confiar nele e mudar para lá de olhos fechados.

Dizendo isso, ela levantou o rosto e deu um breve sorriso. Seu rosto estava meio abatido, mas, assim mesmo, era belo.

-É, a senhora tem razão.

\footnotetext{
${ }^{9}$ Estrada de ferro de Sunzu - antiga linha férrea principal de Tôkaidô, que ia da estação da cidade de Mishima a Shûzenji, cortando a região por uma extensão de $40 \mathrm{~km}$. Atualmente, interliga Izu a Hakone.
} 
Vencida pela confiança depositada pela mamãe no tio Wada, eu também acabei concordando com ela e disse-Ihe:

- Se é assim, eu também fecho os olhos.

Nós duas gargalhamos, mas, em seguida, fomos assoladas por uma grande sensação de melancolia.

Desde então, todos os dias vinham os trabalhadores, a fim de fazer os preparativos para a mudança. Tio Wada também comparecia para nos ajudar, a fim de classificar os objetos vendáveis ou não. Eu e a empregada Okimi ficamos muito ocupadas arrumando as roupas, queimando as coisas inúteis no quintal, mas mamãe permanecia no quarto, sem ajudar em nada, nem mesmo dando instruções.

- O que aconteceu? Não quer ir para Izu? - Perguntei-Ihe com um tom algo áspero, sem obter resposta plausível.

- Não é isso... - Respondia absorta.

Passados dez dias, acabaram-se os preparativos para a mudança. À tarde, no quintal, eu e Okimi queimávamos papéis e palhas. Nisso, mamãe saiu do seu quarto e, da varanda, ficou a nos observar em silêncio. Começou a soprar um frio vento a oeste que parecia ter uma cor acinzentada, e a fumaça da fogueira quase arrastava no chão. De repente, levantei o rosto e, ao encarar mamãe, reparei que seu rosto tinha um aspecto extremamente pálido, nunca antes visto. Dei um sobressalto e disse:

- Nossa, mamãe, a senhora está pálida, o que houve?

Com um débil sorriso, respondeu:

- Não é nada.

Assim dizendo, recolheu-se vagarosamente ao seu quarto.

Nessa noite, como nós tínhamos empacotado todos os acolchoados de dormir, Okimi dormiu no sofá da sala do segundo andar e eu e mamãe dormimos no quarto dela, sobre o par de acolchoados emprestados pelo vizinho. Com a voz embargada e fraca, e para meu espanto, mamãe falou: comigo!

- Sabe, Kazuko, vou a Izu porque você está comigo, viu? É porque você está

Senti-me estremecer e, sem querer, perguntei:

- E se eu não estivesse?

De repente, mamãe caiu em prantos.

- Seria melhor morrer. Eu também queria morrer nesta casa em que seu pai morreu.

Disse isso aos soluços e começou a chorar aos prantos.

Até então, mamãe nunca demonstrara tamanha fraqueza, nem nunca desatara a chorar assim na minha frente. Nem na ocasião do falecimento do papai; nem quando me casei, ou, mais tarde, ao retornar ao lar com um bebê no ventre; nem quando a criança nasceu morta no hospital; nem quando caí doente e fiquei acamada. Nem mesmo quando Naoji agia com má conduta. Ela jamais se mostrou tão fragilizada nos dez anos subseqüentes ao falecimento de papai. Continuou a 
mesma da época em que papai estava vivo, uma mãe tranqüila e meiga. Prevalecemo-nos disso e crescemos mimados. A situação atual era outra, mamãe não tinha mais dinheiro. Fora tudo gasto em nosso proveito, meu e de Naoji, sem se importar consigo mesma. Agora ela precisava abandonar o lar em que morara por muitos anos, e recomeçar a vida numa pequena aldeia montanhosa de Izu, isolada de tudo, somente nós duas. Se fosse maldosa e avarenta, e tivesse nos censurado sempre e, em surdina, amealhasse mais dinheiro, nesse caso, sim, ela jamais teria vontade de morrer, por mais que o mundo revirasse. No entanto, ai que inferno horroroso, miserável e sem salvação é a gente ficar vivendo de parcimônia! Senti angústia pela primeira vez na vida, com o peito sufocado querendo chorar e sem conseguir (seria esta a sensação do que chamamos "austeridade de viver"?), senti como se estivesse anestesiada, fiquei paralisada, dura como pedra, deitada de costas.

No dia seguinte, mamãe continuava pálida e, pela sua expressão, dava para notar que ela gostaria de permanecer na casa, nem que fosse por mais alguns momentos. Nisso, apareceu tio Wada e, como toda a bagagem havia sido praticamente despachada, disse que partiríamos naquele dia para Izu. Mamãe vestiu relutantemente o seu casaco e fez uma leve reverência a Okimi, que the dirigia palavras de despedida, bem como para as pessoas que apareceram para se despedir. Por fim, ela, titio e eu deixamos a casa de Nishikata.

O trem estava relativamente vazio, e conseguimos nos sentar, os três. Titio estava bem-humorado, até cantarolava. Em contrapartida, mamãe estava pálida, taciturna e parecia sentir frio. Ao chegar à cidade de Mishima, fizemos baldeação para a linha férrea de Sunzu e desembarcamos em Izu Nagaoka. Descemos do ônibus, depois de cerca de quinze minutos seguimos em direção à montanha, por um leve aclive, e encontramos uma pequena aldeia. Nesses arredores localizava-se a casa de campo em estilo chinês. ofegante.

- Olhe mamãe, é um lugar melhor do que pensávamos, não é? - Indaguei-a

Diante da varanda da casa de campo, por uma fração de segundos, os olhos dela brilharam de contentamento.

- E, além do mais, veja que ar bom, que ar puro! - Elogiou titio.

- É verdade.

Mamãe sorriu e exclamou:

- Delicioso, o ar daqui é delicioso.

Nós três rimos simultaneamente.

Ao entrarmos no hall, a bagagem de Tóquio já havia chegado. Desde o hall até o quarto, ela ocupava todo o espaço.

- E, depois, vejam a vista da sala. - Dito isso, titio pegou nossas mãos e arrastou-nos até a sala, obrigando-nos a sentar.

Eram mais ou menos três da tarde, o sol de inverno batia no gramado do quintal. Além do gramado, havia um pequeno lago e muitos pés de ameixeiras. Mais para baixo do quintal estendiam-se laranjais; um pouco para frente, havia a estrada aldeã, e, ao longe, os arrozais irrigados. Um pouco mais adiante, havia um pequeno 
bosque de pinheiros, por trás do qual se avistava o mar. Sentada, assim, na sala, parecia que a altura do mar, na linha do horizonte, vinha tocar as pontas dos meus seios.

- Que vista agradável - disse mamãe, num tom lânguido.

- Será por causa do ar? Os raios de sol diferem totalmente dos de Tóquio. Eles parecem filtrados por seda - disse eu, num tom brejeiro.

A casa era composta por um quarto de dez tatami ${ }^{10}$, outro de seis, uma sala de visita em estilo chinês, bem como um hall de entrada de três tatami e uma sala anexa ao banheiro de mesma dimensão. Além disso, havia a sala de jantar, a copa e a cozinha. No andar de cima, havia um quarto de hóspedes. O número de aposentos da casa era suficiente, a meu ver, para nós duas (aliás, mesmo que fôssemos três, com o retorno de Naoji, sobraria espaço).

Titio saiu a fim de tratar da refeição na pensão, que diziam ser a única em toda a aldeia. E, quando, pouco mais tarde, nos foi entregue a marmita, ele abriu-a na sala, bebericou o uísque que trouxera consigo e relatou alguns fracassos sofridos em aventuras vividas na China em companhia do ex-proprietário da nossa casa de campo, o visconde Kawata. Titio mostrava-se alegre e expansivo; mamãe, por sua vez, estava amuada, só tinha tocado de leve sua marmita. Ao começar a escurecer, mamãe se retirou, dizendo:

- Com licença, vou me deitar um pouco.

Eu acompanhei-a até o quarto e ajudei-a a se deitar. Depois, desempacotei os acolchoados e os cobertores da bagagem. Ao notar o desânimo da mamãe, comecei a ficar angustiada. Retirei da bagagem o termômetro e fui medir sua temperatura. Estava com trinta e nove graus de febre.

Titio também ficou apavorado e saiu à procura de um médico na aldeia.

- Mamãe!

Eu a chamava, mas ela apenas se mostrava sonolenta.

Apertei sua delicada mão e comecei a soluçar. Pobre mamãe, pobrezinha. Não, sentia tanta pena de nós duas que, por mais que chorasse, não conseguia aliviar a dor. Chorando, desejei verdadeiramente morrer com ela ali mesmo. Não queríamos mais nada. Pensei que nossas vidas haviam terminado quando saímos da casa de Nishikata.

Decorridas duas horas, titio trouxe um médico da aldeia. Ele parecia bastante idoso e estava trajado em estilo formal japonês, com calça hakama ${ }^{11}$ e calçava tabi $i^{12}$ brancos.

- É possível que vire pneumonia. Mas, mesmo que isso ocorra, não há por que se preocupar.

Após tê-la examinado, fez um diagnóstico assim incerto, aplicou-lhe uma injeção e foi-se embora.

\footnotetext{
10 Esteira com que se forra todo o assoalho de um cômodo. Para indicar a área de uma sala ou de um quarto, usa-se por unidade o tatami.

11 Hakama, tradicional vestimenta japonesa, espécie de saia-calça masculina.

12 Espécie de meia, com divisão entre dedo artelho e os demais dedos.
} 
No dia seguinte, a febre ainda não havia baixado. Titio entregou-me dois mil ienes, recomendou-me que the telegrafasse caso necessitasse de internação e, depois, retornou a Tóquio.

Eu retirei da bagagem os apetrechos da cozinha, preparei um papa de arroz e ofereci à mamãe. Deitada, tomou somente três colheradas e depois recusou o resto, sacudindo negativamente a cabeça.

Pouco antes do meio dia, o médico da aldeia apareceu. Desta vez, não estava vestindo hakama, mas calçava os tabi brancos. evasivas.

- Não seria melhor interná-la? - perguntei-lhe, mas ele continuou com suas

- Não, no momento talvez não haja necessidade. Hoje eu aplicarei uma injeção forte, creio que a febre baixará.

Ele se retirou após aplicar a referida injeção.

A injeção provavelmente surtiu efeito. Logo após o almoço, o rosto de mamãe ficou avermelhado e ela começou a transpirar abundantemente. Ao trocar o pijama encharcado de suor, riu dizendo:

- Pelo jeito, ele deve ser um grande médico.

A febre havia baixado para 37 graus. Fiquei radiante. Corri para a aldeia em direção à única pensão e pedi à dona dez ovos. Cozinhei-os com a gema mole e ofereci-os a mamãe. Ela comeu três e tomou meia tigela de papa de arroz.

No dia seguinte, o grande médico da aldeia apareceu calçando os tabi brancos. Quando agradeci pela injeção do dia anterior, ele assentiu como se dissesse que era normal surtir efeito, e depois fez um cuidadoso exame suplementar, dizendo:

- A senhora sua mãe não está mais doente, portanto, a partir de hoje, ela poderá comer o que quiser e fazer o que for do seu agrado. - Dizia ele, naquele tom esquisito, eu reprimia a vontade de rir. Acompanhei-o até o hall e, ao retornar à sala, deparei com mamãe sentada no leito.

- Realmente, ele é um grande médico, eu já não estou mais doente. Com uma expressão muito feliz, pronunciara essas palavras como num monólogo.

- Mamãe, vamos abrir o shôji ? ${ }^{13}$. Está nevando hoje.

Flocos de neve enormes que lembravam pétalas de peônias começavam a cair levemente. Abri o shôji e sentei-me ao lado de mamãe e, através da janela de vidro, ficamos a contemplar a neve de Izu. falar:

- Já não estou mais doente. - Disse ela num tom de monólogo, e começou a

- Sentada assim, tenho a impressão de que as coisas do passado não passaram de um sonho. Na verdade, um pouco antes da mudança, eu não queria, de forma nenhuma vir para Izu. Gostaria de ter permanecido, nem que fosse um dia ou pelo menos meio dia que fosse, na casa de Nishikata. No momento em que embarcamos no trem, tive a sensação de estar meio morta. Mesmo quando

13 Porta corrediça forrada de papel, que também tem a função de clarear o interior de um ambiente. 
desembarcamos aqui, no começo senti-me alegre mas, à medida que escurecia, comecei a sentir uma saudade imensa de Tóquio. Parecia que o meu peito ia explodir e, então, senti-me desfalecer. A minha doença não é uma coisa comum. Deus me matou uma vez. Ao me ressuscitar, transformou-me em outra pessoa, diferente da que era antes.

$\mathrm{E}$, depois disso, até hoje, nossa existência nessa aldeia montanhosa, na medida do possível, tem decorrido sem novidade e em paz. Os aldeãos também foram muito gentis conosco.

Nós nos mudamos para cá em dezembro do ano passado. Depois, janeiro, fevereiro, março, e até hoje abril, fora os preparativos para as refeições, nós passamos a vida somente tricotando na varanda ou lendo livros e tomando chá na sala chinesa. Vivíamos como se tivéssemos sido esquecidas pelo resto do mundo. Em fevereiro, o florescer das ameixeiras tingiu toda a aldeia com suas flores. Mesmo entrando em março, elas continuaram a exibir a sua beleza até o final do mês, em decorrência da calmaria do vento, que se estendia desde o mês anterior. De manhã até $\mathrm{o}$ anoitecer, as flores das ameixeiras estavam esplêndidas, a ponto de arrancar suspiros. E ao abrir a porta de vidro da varanda, o perfume da flor adentrava na sala. Em fins de março, ao entardecer, sempre soprava um vento, e enquanto preparava a mesa para o jantar, pétalas de ameixeiras entravam pela janela e se molhavam dentro da tigela.

Ao chegar o mês de abril, eu e mamãe nos encontrávamos sentadas na varanda tricotando e o tema da conversa girava, invariavelmente, em torno do plano de cultivo da horta. Mamãe também dizia querer me ajudar... Ai! Ao tentar escrever essas coisas, certamente, como me disse ela, nós duas parecíamos ter morrido e ressuscitado em forma de outra pessoa. Entretanto, uma ressurreição feita a de Jesus seria impossível para nós, humanos mortais. Mamãe falou daquele jeito, mas, ao sorver uma colherada de sopa, ao lembrar-se de Naoji, soltou um suspiro. Ah! $\mathrm{Na}$ verdade, chego à conclusão de que a ferida aberta do meu passado não cicatrizou nem um pouco.

Ai! Como gostaria de escrever tudo, sem ocultar nada. Às vezes, chego a pensar em segredo que a vida pacífica dessa vila do fim do mundo não passa de uma farsa, somente para manter as aparências. Mesmo que Deus tenha-nos dado um breve intervalo de repouso, nada me faz pensar o contrário: que, nesta paz, se acha enrustida uma sombra agourenta, a nos cobrir. Mamãe finge estar animada e feliz, no entanto, dias após dia, ela vai enfraquecendo e meu peito hospeda uma serpente peçonhenta que engorda com o sacrifício dela, e, por mais que eu a contenha, ela vai engordando. Ai! Espero que isso seja somente um efeito sazonal. Para mim, ultimamente, essa vida está se tornando insuportável. Cometi atos tão vis, como queimar ovos de cobras! Essa irresponsabilidade é o que está corroendo a minha alma. E assim, cada vez mais a agonia e a fraqueza da mamãe vão se aprofundando.

Depois que escrevi "Amor", não consegui escrever o resto. 


\section{Capítulo II}

Decorridos cerca de dez dias do incidente com os ovos da cobra, ocorreram seguidamente fatos nefastos, que colaboraram para o entristecimento de mamãe, e contribuíram para encurtar-Ihe a vida. Eu provoquei um princípio de incêndio.

Eu provoquei um incêndio. Durante toda a minha vida, nem em sonhos passou pela minha cabeça fazer uma coisa tão terrível como essa.

Negligência com fogo resulta em incêndio - seria eu uma princesinha mimada a ponto de não perceber fato tão evidente? No meio da noite, ao levantar-me para ir ao banheiro, dirigi-me até o biombo do hall. Nisso, percebi uma claridade na direção do banheiro. Ao espiar casualmente pela vidraça, ouvi o crepitar do fogo e reflexos vermelhos no vidro. Corri descalça para o postigo do banheiro e vi o amontoado de lenha ao lado da fornalha ardendo com espantoso ímpeto.

Corri até a casa do agricultor, nosso vizinho, bati a porta e gritei:

- Sr. Nakai! Acorde, por favor! É incêndio.

O Sr. Nakai já aparentava estar deitado, mas respondeu:

- Sim, já vou!

Enquanto eu implorava, "por favor, por favor, depressa!", ele saiu da casa, vestindo um pijama de yukata ${ }^{14}$.

No momento em que corríamos para debelar o fogo com baldes de água retirados do tanque, mamãe veio do corredor e soltou um grito. Mais que depressa, larguei o balde e subi para o corredor.

- Mamãe, não se preocupe, está tudo bem, fique descansando.

Segurei mamãe, que desfalecia, levei-a ao leito e deitei-a. Em seguida, corri para o local do fogo. Desta vez, pegava a água do ofurô ${ }^{15}$ e a passava para o $\mathrm{Sr}$. Nakai, que a lançava sobre a pilha de lenhas. Mesmo assim a labareda não cedia, tornando inútil todo o trabalho.

\section{- Fogo! Fogo na casa de campo!}

Ouviram-se esses gritos lá de baixo e logo quatro ou cinco aldeãos quebraram a cerca e invadiram a casa. Transportaram com baldes a água do reservatório debaixo da cerca, em revezamento, e em dois ou três minutos tinham debelado o fogo. O telhado do banheiro, por pouco, não fora atingido pelas chamas.

Assim que me senti aliviada, compreendi a causa do incêndio e senti um calafrio. Percebi pela primeira vez que o incêndio ocorrera por descuido meu. À tarde, havia retirado o resto da lenha da fornalha, crente de que havia apagado 0 fogo, e coloquei-a ao lado do monte de lenha. Quando compreendi minha falta, fiquei com vontade de chorar e permaneci imóvel no solo; nisso, ouvi a voz da nora do vizinho da frente, Sr. Nishiyama, a falar: "O banheiro se queimou todo devido à negligência com o fogo da fornalha".

14 Espécie de kimono informal, de algodão, para uso no verão.

15 Banheira feita de madeira. 
Vieram os senhores Fujita - o aldeão chefe -, o guarda Ninomiya, o senhor Ouchi - comandante do corpo de bombeiros - e o senhor Fujita, que me disse 0 rosto risonho e bondoso de sempre:

- Que susto, hein? O que aconteceu?

- Foi tudo culpa minha, a lenha que eu julgava apagada...

Comecei a falar, mas senti-me tão miserável que não pude conter as lágrimas, permaneci cabisbaixa e me calei. E pensei comigo: "Eles me levarão para a delegacia e talvez eu seja incriminada". Eu estava descalça, de pijama. De repente, senti vergonha do meu próprio aspecto e percebi que me encontrava em franca decadência. reconfortante.

- Entendi. E a senhora sua mãe? - O senhor Fujita perguntou-me com ar

- Deitei-a na sala. Coitada, está tão assustada...

- Mas, bem...

O jovem guarda Ninomiya também começou a falar para me confortar.

- Ainda bem que não pegou fogo na casa toda, não é? disse:

Nisso, reapareceu o agricultor, o senhor Nakai, já com a roupa trocada, e

- Isso não foi nada, somente queimou um pouco da lenha, nem chegou a ser um incêndio.

Assim disse ele, ofegante, acobertando-me da minha própria estupidez.

- Ah! É mesmo? Entendi bem.

O aldeão chefe senhor Fujita, fez dois ou três sinais de assentimento com a cabeça e, em seguida, dirigiu-se em voz baixa ao guarda Ninomiya.

- Bem, vamos embora. Recomendações à senhora sua mãe.

Assim dizendo, retirou-se acompanhado do comandante do corpo de bombeiros, o senhor Ouchi, e das demais pessoas, restando somente o guarda Ninomiya. Ele aproximou-se de mim, como num sussurro, e disse, encarando-me: policial.

- Bem, quanto ao incidente dessa noite, não vamos registrar ocorrência

Quando o guarda Ninomiya se retirou, o senhor Nakai perguntou-me em tom sério, muito apreensivo:

- E então, o que disse o senhor Ninomiya?

- Que não registrará ocorrência.

Do lado de fora da cerca ainda se aglomerava a vizinhança e, como se tivesse escutado a minha resposta, a multidão foi se dispersando vagarosamente, repetindo: "Ainda bem, ainda bem".

O senhor. Nakai também me desejou boa noite e se retirou. Fiquei sozinha em pé distraidamente ao redor de restos de lenha queimada, e com os olhos marejados de lágrimas contemplei o céu. Já estava quase amanhecendo. 
No banheiro, lavei as mãos, os pés e o rosto, estava receosa de encarar mamãe, e na saleta de três tatamis do banheiro comecei a ajeitar os cabelos, esperando o tempo passar. Depois fui à copa, onde permaneci, até o raiar do dia, gastando um tempo desnecessário na arrumação dos utensílios da cozinha.

Ao amanhecer, dirigi-me furtivamente à sala, encontrei mamãe já toda vestida, sentada e com ar fadigado, prostrada na cadeira da sala chinesa. Ao me ver, deu um sorriso franco, mas seu rosto estava extremamente pálido.

Sem sorrir, calada, fui me postar atrás da cadeira dela.

Depois de algum silêncio, ela me disse:

- Não foi nada, não é? A lenha é para se queimar, mesmo.

De repente, alegrei-me e ri. Lembrei-me das palavras ditas na aparição ${ }^{16}$, no provérbio bíblico: Na escultura, entalham-se maçãs de ouro. Eu agradeci a Deus a felicidade de ter me dado uma mãe tão compreensiva. E pensei: o que houve ontem à noite é coisa do passado, não vou mais ficar lamentando. Permaneci um longo tempo atrás da cadeira da mamãe, contemplando o mar matinal de Izu, através da vidraça. Senti que a minha respiração estava em sintonia com a dela, serena.

Após um café da manhã leve, comecei a limpar os restos da queimada, quando ouvi a voz da senhora Osaki, proprietária da única pensão existente na aldeia.

$-O$ que houve? O que houve? Somente agora fiquei sabendo, nossa! Afinal o que aconteceu ontem à noite?

Assim dizendo, entrou correndo pelo portão da sebe que rodeava o quintal, lágrimas brilhantes a the escorrer pelos seus olhos.

- Desculpe-me! - Disse-lhe em voz baixa.

- Não tem do que se desculpar, meu bem. O que disse a polícia?

- Que não registraria ocorrência.

- Ah! Ainda bem.

Ela demonstrava sinceridade e uma alegria do fundo do coração.

Perguntei à senhora Osaki de que forma eu poderia retribuir a solidariedade recebida e enviar o meu pedido de desculpas aos aldeãos.

- Dinheiro seria mais conveniente. - Ela respondeu-me, e indicou as casas que eu deveria visitar.

- Escute, meu bem, se você não quiser ir sozinha, eu posso acompanhá-la, viu?

- Não é melhor ir sozinha?

- Você consegue? Claro, é melhor ir sozinha.

- Então, farei isso.

Depois, a senhora Osaki ajudou-me na arrumação do local do incêndio.

${ }^{16}$ Bíblia Sagrada, Velho Testamento, parágrafo 25 versículo 11. 
Ao final do trabalho, solicitei o dinheiro para mamãe, coloquei as notas de cem ienes embrulhadas em papel Mino ${ }^{17}$ dentro de cada um dos envelopes e escrevi: "Desculpe-me."

Em primeiro lugar, fui à repartição pública. Como o aldeão chefe, o senhor Fujita, estava ausente, entreguei o envelope à atendente e me desculpei:

- Ontem à noite, cometi um grave erro. A partir de hoje tomarei mais cuidado, por isso, peço perdão. Recomendações ao senhor Fujita.

Depois disso, dirigi-me à casa do comandante do corpo de bombeiros, senhor Ouchi. Ele apareceu no hall, sorria-me calado e com semblante triste. De repente, não sei porque, fiquei com vontade de chorar.

- Desculpe-me pela ocorrência de ontem à noite.

Com a voz embargada, isso foi tudo que consegui falar; despedi-me depressa, com as lágrimas a escorrerem pelo rosto e a maquiagem toda borrada. Retornei para casa a fim de refazer a maquiagem; quando eu estava calçando os sapatos para sair novamente, mamãe apareceu e me perguntou:

- Você ainda vai a algum lugar?

- Sim, vou sair agora. - Respondi, sem levantar o rosto.

- Está sendo um grande sacrifício, não é? - Disse-me, com pesar.

Confortada pelo carinho de mamãe, consegui concluir o trabalho sem choramingar.

Quando fui à residência do chefe do distrito, ele não estava. Quem me atendeu foi sua nora, que, ao me ver, se derreteu em lágrimas. Na casa do guarda Ninomiya, ele reconfortou-me, dizendo: "Ainda bem, ainda bem". Todos foram bondosos comigo. Em seguida, visitei as casas da vizinhança e eles mostraram compreensão e me consolaram, exceto a nora do senhor Nishiyama, da casa em frente, uma senhora nos seus quarenta anos. Somente ela me repreendeu severamente:

- Por favor, tome cuidado a partir de agora. Não sei se são da nobreza mas desde o começo, estive observando apreensiva o modo de vida de vocês, que pareciam estar brincando de casinha. É como se duas crianças estivessem vivendo juntas, é até estranho que não tivessem causado incêndio até agora. Tome realmente cuidado a partir de agora. Ontem à noite, se o vento tivesse soprado forte, a aldeia toda teria se incendiado.

Essa nora do senhor Nishiyama fora quem se alterara diante do meu descuido de ter provocado o incêndio. Enquanto o agricultor vizinho senhor Nakai, o aldeão chefe, e o guarda senhor Ninomiya me defendiam, dizendo que nem chegara a ser um incêndio, ela ficou gritando do outro lado da cerca, dizendo que o banheiro se queimaria todo, que fora negligência com o fogo da fornalha. Mesmo assim, eu senti sinceridade no sermão da nora do senhor Nishiyama. Ela estava com toda a razão. Não tenho motivos para odiar a nora do senhor Nishiyama. Apesar de mamãe ter me confortado, dizendo que a lenha era para ser queimada mesmo, se, naquela noite, o vento tivesse soprado forte, como disse a nora do

17 Papel produzido na antiga província de Mino que fica ao sul da atual Província de Gifu. 
senhor Nishiyama, a aldeia toda teria incendiada. Se isso tivesse ocorrido, mesmo que eu me matasse, não teria perdão. E se eu morresse, mamãe também não sobreviveria e, acima de tudo, eu mancharia o nome do meu falecido pai. Agora já não existem mais princesas ou nobres, mas se é para sucumbir, gostaria que fosse com dignidade, de maneira mais grandiosa. Provocar incêndio e morrer para redimir tal erro, de forma tão miserável, talvez não levasse minha alma a descansar em paz. De qualquer maneira, preciso ficar mais forte a partir de agora.

A partir do dia seguinte, concentrei-me nos serviços da horta. A filha do senhor Nakai, o agricultor vizinho, ajudava-me de vez em quando. Após a minha conduta vergonhosa pela provocação do incêndio, senti que o meu sangue se tornara denso e escuro. E, antes disso, no meu peito habitava uma serpente maldosa e, desta vez, como até a cor do sangue se modificou um pouco, finalmente tive a impressão de ter-me transformado numa mulher rude do interior. Mesmo estando a tricotar na varanda com mamãe, sentia-me estranhamente sufocada, com falta de ar. Por outro lado, eu me sentia mais confortável cavando a terra da horta.

Chamaria isso de trabalho braçal? Não é a primeira vez que executo um trabalho parecido. Na ocasião em que fui convocada para a guerra, até yoitomake ${ }^{18}$ fui obrigada a executar. As $j i k a t a b i^{19}$ que calço agora para revolver a terra foram distribuídas pelo exército. Nunca havia calçado antes essa tal de jika tabi. Foi naquela época que tive contato com elas pela primeira vez, eram extraordinariamente confortáveis. Hoje, ao calçá-las de novo, senti leveza, como se eu estivesse andando descalça, e pude constatar a alegria dos pássaros e animais ao entrar em contato com a terra sem calçados. Senti uma felicidade imensa e tal alegria quase me doía no peito. Da guerra, somente essa lembrança boa ficou na memória. Pensando bem, a guerra não tem nenhum sentido.

No ano passado, não houve nada.

No ano retrasado, não houve nada.

No ano anterior ao retrasado, também não houve nada.

$\mathrm{Li}$ esse interessante poema num certo jornal. $\mathrm{Na}$ verdade, ao relembrar os acontecimentos daquela época, tenho a impressão de ter vivenciado diversas coisas, mas também, por outro lado, parece que não houve nada. Não quero falar das reminiscências da guerra e nem ouvir falar delas. Apesar de ter morrido muitas pessoas, mesmo assim a guerra é putrefata e tediosa. Seria um capricho meu? Depois da minha convocação e de ter calçado jika tabi e ter sido colocada em trabalho de construções, aquilo não me parecia tão obsoleto. Passei por experiências terríveis, mas, graças aos trabalhos braçais de construção, a minha constituição física se fortaleceu. Até hoje, se a situação apertar, serei capaz de enfrentar o trabalho árduo para poder viver.

$\mathrm{Na}$ época em que a guerra atingiu um estágio desesperador, um homem trajando um fardamento militar apareceu na casa de Nishikata, entregou-me o papel de convocação, e também um papel em que havia escrito a programação diária dos trabalhos. Ao verificar essa programação, vi que teria de viajar em dias alternados

18 Yoitomake é o trabalho de assentamento de solo realizado na construção civil.
19 Jika-tabi meias com solas de borracha que dispensam o uso de calçados. 
para o fundo das montanhas de Tachikawa e, inconscientemente, começaram a jorrar lágrimas dos meus olhos.

- Será que não poderiam mandar outra pessoa? - indaguei, com os olhos marejados de lágrimas, num tom de lamúria.

- Como a convocação para a guerra veio destinada à sua pessoa, assim terá de ser. - Disse o homem com veemência.

Decidi ir.

Chovia no dia seguinte, e nós fomos obrigados a fazer fila no sopé da montanha de Tachikawa, onde ouvimos o primeiro sermão do oficial:

- Com certeza, ganharemos a guerra. - Começou. - Com certeza ganharemos esta guerra! No entanto, se todos não trabalharem conforme o comando do exército, ficará comprometida a nossa estratégia de luta e acabaremos como Okinawa. Gostaria que executassem sempre o trabalho que lhes for ordenado. $\mathrm{E}$, além do mais, pode até haver espiões infiltrados nesta montanha, portanto precavenham-se uns contra os outros. A partir deste momento, vocês ingressam como se fossem soldados; portanto, queremos que fiquem atentos para não divulgar, em hipótese nenhuma, a nossa localização.

Chovia na montanha e cerca de quinhentos convocados, entre homens e mulheres, encharcados até os ossos, ouviram o discurso. Entre os convocados havia alunos e alunas da Escola do Povo ${ }^{20}$. Todos estavam com feições chorosas, tremulando de frio. A chuva já havia transpassado a capa, encharcando a jaqueta e, por fim, molhou minhas roupas íntimas.

Transportei terra no balaio de corda o dia todo e, dentro do trem de retorno, foi impossível conter as lágrimas. No dia seguinte, minha tarefa foi puxar corda num trabalho de construção, e até que me diverti.

À medida que ia à montanha, duas, três vezes, os alunos da Escola do Povo começaram a me encarar de modo estranho e maldoso. Certo dia, enquanto eu carregava o balaio de terra, num grupo de duas ou três pessoas quase trombando comigo, uma delas disse:

- Ah, essa fulana é que é a espiã?

Mesmo tendo falado em voz baixa, acabei escutando e me espantei.

- Por que eles dizem tais coisas? - Perguntei à jovem do meu lado, que também estava carregando o balaio de terra.

-É que você parece estrangeira. - A jovem respondeu com seriedade.

- Você também pensa que sou espiã?

- Não acho. - Desta feita, ela respondeu rindo.

- Olhe, sou japonesa. - assim disse, mas achei que minhas palavras não passavam de um nonsense idiota, e ri sozinha.

20 Designação anterior da escola primária, utilizada entre os anos de 1941 e 1947. 
Num dia de tempo bom, junto a alguns homens, estava carregando umas toras de madeira, quando um jovem oficial que estava a me observar com a cara fechada, apontou-me o dedo.

- Ei, você, venha cá!

Dizendo isso, começou a caminhar apressadamente em direção ao bosque de pinheiros e o meu peito começou a se acelerar num misto de medo e insegurança. Ao chegar ao fundo do bosque, estavam amontoadas tábuas recémtrazidas da serraria. O oficial voltou-se para mim e disse:

- Estão sendo árduos todos os dias, não é? Hoje quero que monte guarda junto a este madeiramento.

Ele me deu um sorriso largo, deixando à mostra os alvos dentes.

- Eu devo permanecer em pé aqui?

- Este local é sossegado e fresco. Você poderá tirar uma soneca sobre as tábuas. Se ficar entediada... não sei se já leu esse livro, em todo caso...

Dizendo isso, ele retirou do bolso do casaco um livro fino e, como se estivesse envergonhado, jogou-o sobre a tábua.

- Fique lendo isso.

No livro estava escrito: Troika ${ }^{21}$.

Apanhei-o e disse-Ihe:

- Muito obrigada. Em casa também tenho alguém que gosta de ler, atualmente encontra-se nos mares do sul... tristeza:

Ao dizer isso, parece que ele interpretou mal, pois proferiu com certa

- Ah, é? É o seu marido, não é? Os mares do sul são dureza... Bem, seja como for, hoje, você ficará montando guarda nesse local. Quanto à sua marmita, trarei depois, portanto, pode ficar descansando calmamente.

Depois, foi-se embora apressadamente.

Estava sentada sobre a madeira lendo o livro, já pela metade, quando o oficial, apareceu dizendo:

- Trouxe a sua marmita. É monótono ficar sozinha, não é?

Assim dizendo, colocou a marmita sobre a relva e partiu apressadamente.

Após a refeição, subi no madeiramento, deitada de lado, e terminei de ler o livro. Depois, comecei a tirar a soneca do dia.

Quando acordei, já passava das três da tarde. De repente, veio na minha mente a imagem daquele jovem oficial. Tive a impressão de tê-lo visto em algum lugar, mas, mesmo forçando a memória, não consegui lembrar-me. Desci do madeiramento e, enquanto ajeitava o cabelo, escutei o som das botas.

21 Nome do romance do escritor russo Nicolai Dimitri Evuch Telechov (1867-1957), publicado em 1890, que descreve a vida miserável e cruel dos imigrantes siberianos na mina de carvão da Rússia. 
- Hoje foi muito cansativo, muito obrigado, você já pode ir embora.

Corri em direção ao oficial a fim de devolver o seu livro e de the agradecer, porém as palavras não saíram. Fiquei calada olhando o seu rosto e, quando nossos olhares se cruzaram, lágrimas transbordaram. De repente, lágrimas brilharam também nos olhos do oficial.

Nós nos separamos sem uma palavra. Desde então, aquele jovem oficial nunca mais tornou a aparecer no nosso local de trabalho. Para mim, aquele foi o único dia em que pude descansar. Depois disso, em dias alternados, tive um trabalho duro nas montanhas de Tachikawa. Mamãe se preocupava com minha saúde, mas, ao contrário, eu me tornei mais forte e, quanto ao trabalho braçal, adquiri mais confiança. Transformei-me numa mulher que não sofre mais com o trabalho duro da lavoura.

Havia dito antes que não gostaria de falar sobre a guerra nem ouvir falar dela, mas, sem querer, acabei relatando as minhas "preciosas experiências". Somente isso é o que deixei relatado sobre as recordações de guerra, pois, quanto ao resto, como dizia o poema:

"No ano passado, não houve nada

No ano retrasado, não houve nada

No ano anterior ao retrasado, também não houve nada."

Era isso, apenas bobagens, e o que me resta é esta triste e vazia realidade de ter um par de jika tabi.

Desde a menção às jika tabi, acabei divagando, relatando coisas inúteis. Calçando essas jika tabi, que posso considerar minha única recordação da guerra, trabalho na horta quase todos os dias e me distraio da inquietação e da ansiedade ocultas no fundo do meu peito, mas mamãe vai-se enfraquecendo a olhos vistos, a cada dia que passa.

Ovos de serpente.

Incêndio.

Desde aquele dia, sinto que mamãe foi ficando cada vez mais doente. Ao contrário dela, tenho a impressão de que aos poucos vou-me tornando mais grosseira e vulgar. Não sei mais, mas tenho a nítida impressão de que fortaleço-me sugando a seiva de mamãe.

Mesmo no caso de incêndio, ela amenizou brincando que a lenha serve para se queimar, e não disse mais nada a respeito, procurando, dessa maneira, me confortar. O choque que ela sentiu deve ter sido no íntimo dez vezes mais forte do que o meu. Desde aquele incêndio, mamãe ocasionalmente geme no meio da noite. Nas noites de ventania, ela finge ir ao banheiro e sai do leito para rondar ao redor da casa. E o seu rosto tem sempre uma aparência pálida, parecendo até caminhar com dificuldades. Mostrou interesse em ajudar na horta. Tentei dissuadi-la, mas ela transportou quatro ou cinco baldes de água do poço, e no dia seguinte, dizendo estar com dores terríveis no ombro a ponto de lhe ser difícil respirar, permaneceu acamada o dia todo. Desde então, desistiu de mexer na horta. Às vezes, saía para a horta somente para me ver trabalhar.

- Dizem que quem gosta de flores de verão morre no verão, seria verdade? 
Naquele dia, também, mamãe ficou a observar os trabalhos da horta e, de repente, começou a dizer coisas assim. Eu permaneci calada enquanto regava os pés de berinjela. Ah! Falando nisso, já estavamos no verão.

- Eu gosto de flor de acácia de Constantinopla, mas nesse jardim não há nenhuma muda, não é? - mamãe falou com suavidade. propósito.

- Mas temos um monte de espirradeiras. - Respondi bruscamente de danadinhas.

- Eu detesto espirradeiras. Gosto de flores de verão, mas aquelas são muito

- Eu prefiro as rosas. Como elas florescem nas quatro estações, os apreciadores dessa espécie precisam morrer quatro vezes, na primavera, verão, outono e inverno?

Nós rimos juntas.

- Não quer descansar um pouco?

Mamãe continuou rindo e disse:

- Hoje tenho um assunto a tratar com você.

- O que é? Se for conversa de morte, não quero ouvir.

Fui atrás de mamãe, sentei-me a seu lado no banco debaixo do caramanchão de glicínias. Elas já tinham terminado a florescência, e um tênue raio de sol filtrava as folhas que caíam sobre nossos colos, tingindo-os de verde.

- Há muito tempo gostaria que me ouvisse, esperando uma ocasião em que nós nos encontrássemos com boa disposição. Até hoje esperei essa chance. De qualquer modo, não é uma conversa agradável, mas hoje posso falar sem rodeios, portanto, peço-lhe que tenha paciência e me ouça até o fim. Na verdade, Naoji está vivo.

Senti meu corpo enrijecer.

- Faz cinco ou seis dias, recebi uma carta do seu tio Wada. Um exfuncionário dele regressou recentemente dos mares do sul. Essa pessoa apareceu na empresa para cumprimentá-lo e, no fim da conversa, teria contado ao seu tio que estivera alistado na mesma unidade de Naoji e que ele está bem, e que em breve retornará. Mas tem uma coisa desagradável... de acordo com a conversa dessa pessoa, Naoji está viciado em ópio.

- Outra vez?

Retorci a boca como se tivesse comido fel. Nos tempos do colégio, Naoji imitou certo romancista, e viciou-se em entorpecentes e, em razão disso, endividouse com uma quantia estrondosa na farmácia. Mamãe levou dois anos para saldar totalmente a dívida.

- É, pois é. Parece que começou tudo de novo. Mas, enquanto não se desintoxicar, ele não poderá regressar para o lar. Com certeza voltará curado do vício, segundo essa pessoa. De acordo com a carta do seu tio, mesmo que Naoji retorne curado, seria impossível empregar uma pessoa tão imprudente de imediato, até uma pessoa sã começa a se sentir louca na atual Tóquio, tão convulsiva. Não se 
pode prever a atitude de um viciado convalescente, que poderia ter uma recaída; então a primeira ordem do seu tio Wada é que recebamos Naoji aqui na casa de campo de Izu, não o deixando sair para nenhum lugar, e que o obriguemos a repousar por um bom tempo. A outra coisa é que o seu tio diz que não temos mais dinheiro. Parece que seria muito trabalhoso remeter o dinheiro como tem feito até hoje, por causa do congelamento de depósitos, imposto de renda, etc. Daí, com o retorno de Naoji, se nós vivermos sem trabalhar, seu tio se sacrificaria demasiadamente para arranjar o dinheiro do nosso sustento; assim, ele diz para fazer uma escolha entre Kazuko se casar e procurar emprego... Essa é a ordem.

- Empregar-me, eu...? Ele quer dizer trabalhar como empregada doméstica?

- Não, seu tio refere-se... àquele ...de Komaba... - e citou o nome de certo príncipe.

- Segundo seu tio aquele príncipe tem ligação consangüínea conosco, caso a empregasse lá como professora particular da princesa, você não se sentiria sozinha e não passaria incômodos.

- Não haveria emprego em outro lugar?

- Outro emprego seria impossível para você, segundo seu tio.

- Por que impossível, me diga, por que impossível?

Mamãe só sorria melancolicamente, e nada me respondia.

- Ai! Eu não quero mais saber dessa conversa.

Eu mesma senti que extrapolei na resposta, pensei; mas não pude parar.

- Eu, com estas jika tabi, com estas jika tabi...

Ao dizer isso, as lágrimas jorraram e, sem querer, caí em prantos. Levantei o rosto e, com as mãos enxugando as lágrimas, ao encarar mamãe, pensava que não podia fazer aquilo. As palavras saíam inconscientemente, uma após outra, como se o meu corpo não pertencesse a mim.

- A senhora não me disse uma vez? Porque eu existo, que fico junto da senhora, que viria a Izu? Não disse? A senhora não disse que, se eu não existisse, preferia morrer? Por isso eu não fui a lugar nenhum, para ficar a seu lado, calçando a jika tabi todos os dias com o único intuito de cultivar verduras frescas e saborosas para a sua saúde, mas estou vendo que logo que a senhora escuta a respeito da volta de Naoji, me vê como um estorvo e quer que eu vá me empregar na casa desse tal príncipe. Para mim isso é demais... demais.

Até eu pensei ter-me excedido em palavras tão cruéis, mas elas saíram como se fossem independentes da minha pessoa.

- Se nós ficarmos pobres e sem dinheiro, por que não vender nossas roupas? Não seria o caso de nós vendermos até essa casa? Eu posso fazer qualquer coisa, poderia ser funcionária da repartição dessa aldeia. Se não me empregarem lá, posso trabalhar nas construções. Pobreza, isso não é nada. Se mamãe me amasse, eu gostaria de permanecer a seu lado a minha vida inteira, assim pensava eu, mas pelo jeito a mamãe deve amar mais a Naoji do que a mim, não é isso? Eu partirei. Está bem, eu saio. De qualquer modo, meu gênio não combina com o de Naoji mesmo, se nós vivêssemos sob o mesmo teto, seríamos os 
três infelizes. Eu vivi por longo período a sós com a senhora, já não tenho nada a reclamar. Daqui para frente, Naoji que viva com a senhora, sem interferência de terceiros, e que ele the dedique muito, mas muito amor filial, mais do que eu. Eu já estou farta. Estou farta da vida que vivi até hoje. Vou-me embora. A partir de hoje deixarei esta casa. Tenho para onde ir.

Dito isso, levantei-me.

- Kazuko!

Mamãe censurou-me severamente, com uma expressão austera, nunca demonstrada anteriormente. Levantou-se, silenciosamente, e encarou-me. Pareceume um pouco mais alta que eu.

Pensei em dizer desculpe-me, mas não consegui pronunciar. Pelo contrário, acabou saindo outra coisa da minha boca.

- Me enganou. A senhora me enganou. Aproveitou-se de mim até a chegada de Naoji. Não passo de uma reles empregada sua. Já que o serviço acabou, me manda para servir ao tal do príncipe.

Dei um grito e, do jeito mesmo em que estava, de pé, chorei convulsivamente.

- Como você é tola!

Mamãe falou baixinho, mas sua voz estava trêmula de raiva.

Levantei o rosto e disse:

- É isso mesmo, sou tola mesmo. Por isso fui enganada. Sou tola, por isso sou rejeitada. Seria melhor eu não ficar, não é? Pobreza - o que é isso? Dinheiro o que vem a ser? Eu não entendo. Amor, amor de mãe, essa foi a razão da minha existência até hoje.

Deixei escapar essas palavras insensatas, que na verdade não deveria nem ter pensado.

Mamãe virou o seu rosto de leve. Ela estava chorando. Pensei em abraçá-la e dizer me perdoe, mas me incomodava um pouco o fato de as minhas mãos estarem sujas em decorrência dos trabalhos de horta, e desisti:

- Melhor eu sumir, não é mesmo? Eu sairei. Tenho aonde ir.

Dito isso, eu corri para o banheiro, aos prantos, lavei o rosto, as mãos e os pés, e depois me dirigi ao quarto para me trocar para traje ocidental. Enquanto assim o fazia, queria chorar mais ainda; subi para o quarto de cima me atirei na cama, e cobri o corpo inteiro com o cobertor. Chorei até o ponto de exaustão. Nesse tempo, senti que ia desfalecendo e, aos pouco, comecei a sentir saudades imensas de certa pessoa. E gostaria de ver o seu rosto, ouvir a sua voz. Esse sentimento foi me dilacerando o meu peito a ponto de eu ficar em estado de torpor. Mesmo se me aplicassem moxa ${ }^{22}$ na planta dos meus pés, eu ficaria inerte, insensível.

Ao entardecer, mamãe entrou de mansinho no quarto, acendeu a luz, com um estalido aproximou-se da minha cama, e me chamou ternamente:

22 Tratamento medicinal baseado em mecha de algodão aplicada acesa sobre a pele para cauterizá-la. 
- Kazuko.

- Sim, senhora. encará-la.

Sentei-me na cama, ajeitando os cabelos com as duas mãos, e sorri ao janela.

Mamãe também sorriu de leve e afundou-se no sofá que havia perto da

- Pela primeira vez na minha vida, desobedeci às ordens do seu tio Wada. Escrevi a resposta para o seu tio Wada. O problema dos meus filhos, deixe-os por minha conta, escrevi. Kazuko, nós venderemos as nossas roupas. Vamos vender sem dó, sem piedade, as nossas roupas, faremos gastos fúteis e vamos aproveitar a vida de luxo, não quero mais que você trabalhe na horta. Vamos comprar verduras caras, não é? Aquele trabalho duro de horta para você é muito penoso.

$\mathrm{Na}$ verdade, o trabalho diário da lavoura estava ficando meio puxado para mim. Se pouco antes agira daquela maneira tresloucada, era porque o cansaço do trabalho se confundira com a tristeza, redundando em desgosto por tudo.

Permaneci calada e cabisbaixa sobre a cama.

- Kazuko!

$-\operatorname{Sim}$ ?

- Você me disse que tinha lugar para ir, aonde seria?

Eu enrubesci até o pescoço.

- Seria o senhor Hosoda?

Fiquei calada.

Mamãe suspirou profundamente,

- Posso falar de coisas passadas?

- Por favor, - Disse-lhe baixinho.

- Quando você retornou para a casa de Nishikata, após deixar a casa de senhor Yamaki, eu não tinha intenção de condená-la, mas só disse uma coisa, que foi: "mamãe foi traída por Kazuko". Eu lhe disse, não é? Lembra-se? Então você começou a chorar... Achei também que utilizei uma palavra muito cruel ao dizer que você tinha me traído, mas...

$\mathrm{Na}$ verdade, eu chorava de felicidade naquela ocasião, pois senti-me agradecida pelas palavras de mamãe.

- Escute: a mamãe lhe falou naquela ocasião que se sentiu traída não pelo fato de você ter deixado a casa do senhor Yamaki. Foi quando escutei da boca de senhor Yamaki que você tinha um caso amoroso com o senhor Hosoda. Quando me foi dito isso, eu me senti empalidecer, pois o senhor Hosoda, muitos antes, já tinha mulher e filhos, mesmo que você pensasse nele, nada podia ser feito...

- Que nós éramos amantes? Que coisa horrível! Isso não passa de uma suspeita sem fundamento que ele alimentava!

- Será? Acaso, você não estaria ainda pensando no senhor Hosoda? Não é mesmo? Você disse que tinha aonde ir ... aonde era? 
- Com certeza, não é a casa do senhor Hosoda.

- Ah, é? Então, onde seria?

- Mamãe, eu, outro dia, estive pensando, em que ponto o ser humano difere completamente dos outros animais, sabe? Palavras, inteligência, raciocínio, ordem social, em tudo pode haver diferença de grau, mas todos os animais são portadores dessas coisas, não acha? Até crenças é possível que tenham. O homem se orgulha de ser o rei da criação; no entanto, não the parece que não tem nada que o diferencie fundamentalmente dos outros animais? Acontece, mamãe, que encontrei uma única coisa. A senhora não sabe, não é? O que não existe em outro ser vivo e há tão somente no homem. É o segredo... que me diz?

Seu rosto enrubesceu levemente, e ela abriu um sorriso lindo.

- Ah, tomara que o segredo de Kazuko produza bons frutos. Todas as manhãs peço ao seu pai para que a faça feliz.

Em meu peito, aflorou a lembrança da paisagem do campo outonal, onde eu costumava passear de carro com papai dirigindo nos campos de Nasuno e, no meio da viagem, eu descia do carro para observar as flores: lespedezas, cravos franjados, gencianas, patrínias floresciam sobre os campos outonais. As uvas silvestres ainda estavam verdes.

Depois disso, fomos para o Lago Biwa e andamos de barco. Mergulhei e senti os peixinhos que habitam as algas baterem nos meus pés, e no fundo do lago suas sombras refletiam-se em movimento. Essa situação, que nada tinha a ver com a circunstância presente, ressurgiu e depois se apagou de repente da minha memória.

Eu desci da cama, abracei-me ao colo de mamãe e consegui balbuciar:

- Mamãe, desculpe o que disse agora há pouco.

Ao recordar, vejo que foram esses os dias em que, pela última vez, brilhou o derradeiro lampejo da nossa felicidade. Desde então, com o regresso de Naoji, teve início o nosso verdadeiro inferno. 


\section{Capítulo III}

Uma sensação de desamparo de quem não consegue mais, de jeito nenhum, continuar a viver. Seria este aquele sentimento que chamam de inquietação? Em meu peito bate uma onda de angústia, semelhante a nuvens brancas que, após uma chuva repentina, se dispersam numa correria pelo céu, apressadamente, e elas ora apertam meu coração ora o dilatam e, com isso, o pulso começa a falhar, a respiração fica entrecortada, a visão escurece, todo o meu corpo parece esvair-se pela ponta dos dedos da mão. Por causa dessa sensação, não consegui continuar a tricotar.

Ultimamente, tem chovido sem parar. Tive vontade de permanecer na letargia, mas hoje arrastei a cadeira de vime para a varanda com o firme propósito de terminar o suéter que havia começado e deixado inacabado na primavera daquele ano. A lã era cor-de-peônia, pálida e desbotada; queria acrescentar nela uns tons de azul cobalto para sua conclusão. A lã cor-de-peônia era a mesma de vinte anos atrás, quando eu ainda cursava a escola primária e mamãe fizera um cachecol para mim. Sua extremidade terminava em capuz pontiagudo e, ao experimentá-lo e espiar no espelho, achei que eu me assemelhava a uma diabinha. Além do mais, sua cor destoava completamente da dos colegas da escola. Eu o detestava com todas as minhas forças.

Certo dia, uma das colegas da escola, extremamente rica, vinda da região oeste do Japão, apesar de tê-lo elogiado com ar de superioridade - "Você está usando um cachecol lindo" -, me fez sentir vergonha do referido acessório. Desde então, nunca mais o utilizei, larguei-o em algum canto, por um longo tempo. Foi aquele mesmo que, nesta primavera, com a intenção de desenterrar coisas velhas, comecei a desfiar para transformar em um suéter novo, mas como a tonalidade desbotada da linha não me agradou, desisti novamente. Como hoje estava à toa, retirei-o a fim de dar continuidade ao trabalho interrompido. Enquanto eu tecia a linha, pareceu-me que a lã pálida, cor-de-peônia, e o céu pardacento e chuvoso se diluíam, tornando impossível a descrição da tonalidade de sua maciez e suavidade. Ao constatar sua coloração, percebi que havia feito uma perfeita combinação tonal. Eu não sabia do importante detalhe de que era preciso pensar na harmonia da cor do céu e da roupa. Harmonia - que coisa linda -, senti-me um pouco surpresa e pasma. O céu cinzento e a lã pálida cor-de-peônia; ao combinar os dois, surpreende-me que ambos parecessem tão vívidos ao mesmo tempo. A lã repentinamente tornava-se quente ao toque da mão, e eu sentia que o céu frio e chuvoso também se tornava macio e aveludado. Isso fazia lembrar a pintura da catedral envolta em brumas de Monet ${ }^{23}$. Tive a impressão de que, graças à cor daquela lã, compreendia pela primeira vez o significado da palavra "gout". Bom gosto.

${ }^{23}$ Claude Monet (1840-1926), pintor e principal representante do impressionismo francês. Ele retratou a delicada transformação da coloração ao ar livre. Tema de sua pintura: ninféias, álamos, a catedral de Rouen, a estação de Saint-Lazare, O Sena - representados sob luzes diferentes conforme as horas do dia ou as estações do ano. 
Mamãe estava perfeitamente ciente de que aquela cor pálida harmonizava com o céu de inverno, que anuncia a neve. Ela escolhera a lã especialmente e eu, tola, rejeitei-a, sem saber da sua boa intenção. Como era criança, não me obrigou a usar nada e deixou que eu agisse a meu modo. Até eu compreender a verdadeira beleza daquela cor, foram necessários vinte anos e, sobre aquele tom, mamãe nunca pronunciou nada, esperou calada, como quem nada sabe. Do fundo do coração, penso como mamãe foi boa para conosco e, sem nos importarmos, eu e Naoji judiamos dela, nós a enfraquecemos, talvez até poderíamos provocar o seu óbito e, de repente, brotou no meu peito um temor mórbido de que nós dois abreviaríamos a sua vida, por causa das inquietações e esgotamentos. Quanto mais pensava, mais nefasta e horrível previsão fazia para o futuro. E, inquieta, já sem ânimo nenhum para continuar a viver perdi força até nas pontas dos dedos, larguei as agulhas de tricô no colo, suspirei fundo, cabisbaixa, e, com os olhos cerrados, chamei, sem querer:

- Mamãe!

Ela lia um livro, no canto da sala, apoiada na mesa.

- Sim? - respondeu, com certa estranheza.

Eu estava confusa e disse-lhe em voz alta:

- Finalmente a rosa floresceu. Mamãe, a senhora tinha percebido? Eu notei somente agora. Até que enfim, floriu!

A roseira ficava logo em frente à varanda da sala. Ela fora trazida pelo tio Wada de longe, há tempos, não sei bem se foi da Inglaterra ou da França. Ela fora replantada pelo tio Wada no quintal desta casa de campo cerca de dois ou três meses atrás. Naquela manhã, eu já tinha percebido que, finalmente, ela tinha florido. Entretanto, fiz aquele escândalo todo, como se eu não tivesse notado, para disfarçar a minha confusão. A flor de cor púrpura floria com firmeza e força.

- Eu já sabia. - Disse ela, suavemente. - Para você, parece que um fato corriqueiro como este tem grande importância, não é?

- Talvez tenha. Tem pena de mim?

- Não, eu apenas disse que você tem dessas coisas. Grudar pinturas de Renoir $^{24}$ nas caixas de fósforos, fazer lencinhos para as bonecas... Gosta dessas coisas, não? Além do mais, ao ouvi-la falar da roseira do quintal, parece referir-se a elas como pessoas vivas.

-É que não tenho filhos.

Essas palavras saíram da minha boca inesperadamente. Depois de tê-las dito, sobressaltei-me e, para disfarçar atrapalhada, comecei a remexer o tricô que estava no meu colo.

-É, já está com vinte e nove anos!

Tive a impressão de ter escutado nitidamente uma voz masculina pelo telefone. Fiquei com tanta vergonha, que me ruborizei a ponto de meu rosto inflamar.

24 Auguste Renoir (1841-1919). Pintor impressionista francês. Com predomínio de tons claros e suaves, pintava mulheres, crianças, e rosas. Na sua segunda fase pintava mulheres de busto nu. 
Mamãe, sem nada opinar, retornou à sua leitura. De uns dias para cá, ela começou a usar uma máscara de gaze no rosto, e não sei se por causa disso, ultimamente, ela tem ficado bastante calada. Ela a usa obedecendo à ordem de Naoji. Ele regressou das ilhas do Pacífico Sul, cerca de dez dias atrás, com rosto muito queimado.

Sem nenhum aviso, veio entrando pelo portão dos fundos, num entardecer de um dia de verão, dizendo:

- Ai! Que coisa horrível! Que casa de mau gosto. Coloquem uma tabuleta: "Mansão Chinesa". "Temos shû-mai".

Esse foi o primeiro cumprimento de Naoji, no momento em que nos encontramos, depois de tanto tempo.

Fazia dois ou três dias que mamãe estava acamada, com dores na língua. $\mathrm{Na}$ ponta não apresentava nada, estava somente dolorida, segundo ela, quando fazia movimentos, e nas refeições tomava caldo ralo de arroz. Perguntei-lhe se deveríamos chamar um médico. Ela acenou negativamente com a cabeça e respondeu com um sorriso amarelo:

- Ele caçoará de mim.

Passei-Ihe Lugol ${ }^{25}$, mas, como não surtiu nenhum efeito, comecei a ficar inquieta. Nisso, Naoji retornou da guerra, e foi sentar-se na cabeceira da cama de mamãe para cumprimentá-la, dizendo: "Estou de volta". Levantou-se em seguida e começou a examinar a pequena casa. Eu o segui e perguntei-lhe:

- E então? A mamãe... você acha que ela mudou?

- Mudou. Mudou... Está magra e fraca. É melhor que morra logo. Num mundo como esse, pessoa como ela não deve viver. Ela está tão infeliz, que mal posso encará-la.

$$
\text { - E eu? }
$$

- Está ficando vulgar. Está com a cara de quem tem três ou quatro amantes. Tem saquê? Hoje à noite vou me embebedar.

Fui à única pensão da aldeia e pedi à senhora Osaki que me arranjasse um pouco de saquê para o irmão que havia retornado da guerra. Ela respondeu que infelizmente estava em falta. Retornei para casa e comuniquei o fato a Naoji, que, com o rosto transtornado, nunca antes visto, disse, todo irado: "Ora, você é que é uma péssima negociante!". Perguntou-me o endereço da pensão e saiu correndo, calçando o getá26 que estava na varanda e não retornou para casa. Eu preparei maçãs assadas, de que Naoji tanto gostava, e depois preparei pratos feitos à base de ovos. Até troquei a lâmpada da sala de jantar para uma mais potente e, assim, esperei-o por um longo tempo. Nisso, apareceu a senhora Osaki na porta da cozinha.

- Com licença. Será que está tudo bem? Olhe... Ele está tomando shôchû́${ }^{7}$.

Solução Lugol era utilizada para a inflamação da garganta.

Espécie de tamanco feito de madeira, com dois saltos perpendiculares à planta dos pés.

Aguardente, geralmente fabricado de batata doce. 
Falou sussurrando, encarando-me fortemente, como se fosse a coisa mais importante do mundo, arregalando os olhos arredondados parecidos com os de uma carpa.

- Mas... shôchû? - aquele álcool metílico?

- Não, não é álcool metílico, mas...

- Escute... ao beber isso, a pessoa não adoece, não é?

- Sim, mas...

- Deixe-o tomar.

A senhora Osaki foi embora parecendo estar engolindo em seco.

Dirigi-me a mamãe:

- Parece que Naoji está na senhora Osaki, bebendo.

Ao informá-la, ela deu uma risada, entortando um pouco a boca.

- Ah é? Será que deixou o vício do ópio? Você pode jantar. E depois, esta noite, vamos dormir nós três juntos no quarto. Nós arrumaremos o acolchoado de Naoji no meio.

Fiquei com vontade de chorar.

Naoji retornou altas horas da noite, fazendo ruído com passos largos. Dormimos todos no mesmo quarto, sob o mesmo mosquiteiro.

- E se você falasse para a mamãe sobre os mares do sul? - perguntei-Ihe, deitada. Respondeu-me rispidamente:

- Não tenho nada, não tenho nada para falar. Eu esqueci tudo. Ao chegar ao Japão, tomei o trem e, da janela, vi os arrozais irrigados, pareciam esplêndidos. Só isso. Ora, apague essa luz. Não consigo dormir assim.

Desliguei a luz. Os raios de luar de verão inundaram o mosquiteiro. Na manhã seguinte, Naoji ficou debruçado no leito fumando e contemplando o mar ao longe:

- Está com a língua dolorida?

Disse isso como se, pela primeira vez, tivesse percebido o estado de saúde da mamãe.

Ela apenas sorriu debilmente.

-- Ah, esse negócio deve ser psicológico. À noite, a senhora dorme de boca aberta, não é? É feio! Use máscara. Será bom embeber a gaze em Rivanol e colocar dentro da máscara à noite.

Ao escutar suas palavras, caí na gargalhada.

- Como se chama esse tratamento?

- Chama-se tratamento estético.

- Mas, com certeza, mamãe detesta máscaras.

Mamãe tem horror não só a máscaras como ao uso de vendas ou óculos. respondeu:

- E então, mamãe, a senhora usará máscara? - perguntei-lhe, e ela 
- Eu usarei. - foi sua resposta, emitida em voz baixa, e séria. que for.

Senti-me abalada. Tudo que Naoji diz mamãe acata, sem pestanejar, seja o

Logo após o café da manhã, fiz a máscara com a gaze embebida em Rivanol, de acordo com o que Naoji havia recomendado, e levei-a para a mamãe. Sem se erguer do leito, ela apanhou-a e ajustou o cordão atrás das orelhas como se fosse uma criancinha, o que me entristeceu.

À tarde, Naoji, com pretexto de se encontrar com amigos, bem como com seu mestre em assuntos literários, em Tóquio, vestiu um terno e, arranjando dois mil ienes com mamãe, partiu para lá. Desde então, decorreram dez dias e nada de ele retornar para casa. Enquanto isso, mamãe faz uso diário da máscara, esperando pelo seu regresso.

- Esse Rivanol é um bom remédio. Ao utilizar essa máscara, a dor da língua desaparece.

Ela proferiu essas palavras rindo, mas tenho a impressão de que está mentindo. Diz: "Já estou bem". Agora ela está caminhando, mas continua sem apetite, e o seu aspecto taciturno é motivo de preocupação e me faz também ansiar por Naoji e me conduz a pensar: "O que estará Naoji aprontando em Tóquio!". Com certeza, deve estar se divertindo pela cidade inteira em companhia daquele romancista, senhor Uehara, envolvido no redemoinho caótico da cidade. Quanto mais penso nisso, mais me angustio e acabo piorando as coisas com minhas bobagens como aquela do anúncio da rosa, ou do fato de eu não ter filhos.

- Ah! - Exclamei e levantei-me sem saber a direção a seguir, nem o que fazer. Subi os degraus meio cambaleando e entrei no quarto ocidental do andar superior.

Ali seria o quarto de Naoji; quatro ou cinco dias atrás, eu havia conversado com mamãe, e pedimos ajuda ao senhor Nakai, o vizinho agricultor. Transportamos para lá o guarda-roupa, a mesa, a estante, mais cinco ou seis caixas de madeira abarrotadas dos livros e cadernos de Naoji. Enfim, tudo que havia no quarto dele da antiga casa em Nishikata. Ao retornar de Tóquio, ele colocaria as coisas no seu devido lugar e ao seu gosto. Achei melhor deixar tudo espalhado pelo quarto, onde não havia mais espaço para colocar os pés. Foi por acaso que avistei, dentro de caixa de madeira, junto aos meus pés, um caderno dele.

Estava escrito Diário de $Y_{\text {ûgao }}^{28}$ e, no seu interior, estavam registradas coisas como as que se seguem, em ordem desconexa. Parecia o depoimento atormentado da época em que ele esteve sob efeito de entorpecentes.

Sensação de morrer consumido pelo fogo. Embora eu sinta dor, não consigo soltar um grito lancinante, nem uma, nem meia palavra, sequer. Não tente disfarçar essa percepção da profundeza infinita do inferno, sem precedentes, desde a mais remota antigüidade, desde a formação da vida humana.

Filosofia? Mentira. Princípios? Mentira. Ideais? Mentira. Ordem? Mentira. Sinceridade? Verdade? Pureza? Tudo mentira. Dizem que as glicinias de Ushijima têm mil anos, e as de Kumano,

${ }^{28}$ Corriola, flor que se abre ao entardecer. Alusão ao capítulo de mesmo nome da obra Genji Monogatari. (Narrativas de Genji). 
centenas de anos, e, ao ouvir que os mais compridos cachos de flores daquelas atingem perto de três metros, $e$ os destas quase dois, só de pensar nelas o meu coração exulta.

Ele também é filho de homem. E está vivo.

A lógica, afinal, não passa de amor à lógica. Não é amor ao homem que está vivo.

Dinheiro e mulher. A lógica, envergonhada, parte, caminhando apressadamente.

História, Filosofia, Educação, Religião, Direito, Política, Economia, Sociologia - no lugar dessas ciências todas, mais nobre é o sorriso de uma donzela - essa é a constatação corajosa do Doutor Fausto. ${ }^{[29]}$

Estudo é outra denominação de vaidade. É o esforço do homem para deixar de ser homem.

Posso até jurar na presença de Goethe. Eu sou capaz de escrever bem quanto eu quiser. Sem errar uma construção, com dose exata de humor, com tristeza convincente, com persuasão de levar o leitor às lágrimas. Posso escrever o romance perfeito, lido em voz alta, como se estivesse vendo o filme. Seria capaz de escrever tais coisas, sem me envergonhar? Para mim, há uma impressão de sovinice seme lhante à escrita de obra-prima. Altivez para ler romance. Só os loucos agem assim. Se fosse assim, nós deveríamos ler trajados a rigor. Ah, as grandes obras são justamente aquelas que não impõem altivez. Eu escrevo um romance, de propósito, desestruturado, sem uma elaboração prévia, somente para observar a reação dos amigos, e me encho de prazer ao constatar que eles se divertem com as minhas escritas desastrosas. Ah! O sorriso franco do amigo nessa ocasião.

Inabilidade, aparência desleixada, tocando corneta de frinquedo, aqui está o maior idiota de todos os tempos do Japão, tu és, ainda, uma pessoa bondosa e saudável! - Por que esse desejo de amor ao próximo? - Afinal, o que é isso?

O amigo com ar triunfante lembra: "Esse cara tem um péssimo hábito, portador de sentimentos preciosos, mas, ele os desperdiça”. Ignora que é amado.

Existiria alguém que não seja libertino?

Penso que seria insípido.

Quero dinheiro.

Caso contrário,

Morte natural, enquanto durmo!

Tenho uma dívida de quase mil ienes com a farmácia. Hoje, eu trouxe para casa, um gerente da casa de penhores e o conduzi em surdina ao meu quarto e falei: "Se tiver algo valioso neste quarto, e for objeto de penhor, pode levar, preciso de dinheiro urgente". O gerente, sem avaliar atentamente cada objeto exposto no quarto, retrucou: "Desista, esses objetos não the pertencem". "Está 6em, se é assim, carregue os objetos que comprei até hoje com a minha mesada." - Repliquei-Che com arrogância, juntei as bugigangas mas, dentre eles não havia um único objeto digno de penhora.

Para começar, a mão de gesso. A mão direita de Vênus. Mão que parecia uma dália, Granquíssima, simplesmente assentada sobre um pedestal. Entretanto, ao olhar detalhadamente, percebia-se que era a

29 Doutor Fausto. Personagem da famosa peça de teatro escrita pelo alemão Johann Wolfgang Von Goethe (1749-1832). No primeiro ato, Fausto faz um acordo com o satã Mefistófeles e se transforma num jovem. Depois de ter se desesperado com informação e conhecimento, perambula pelo mundo e toma conhecimento do prazer. Nasce a tragédia que envolve a jovem Gretchen. No segundo ato, Fausto arranja um casamento com Helena. Ele morre pensando em construir um mundo novo e ideal da espécie humana, por fim sua alma sobe aos céus e alcança a redenção. 
Vênus que, ao ser surpreendida por um homem na sua nudez, assustara-se toda ruborizada, envolta pelo redemoinho da vergonha, contorcendo todo o seu corpo, como se estivesse submetida a uma chama ardente. $\mathcal{A}$ sua vergonha era tanta que ela quase perdia os sentidos. Através daquela delicada e alvíssima mão, onde não se via a impressão digital, nem os sulcos na palma da mão, conseguimos ver nitidamente tal expressão, que chegava a sufocar o nosso peito. Dá para ver isso. - Disse ao gerente. Este, por sua vez, emitiu sua opinião: "Está claro, na verdade, essa coisa não passa de uma inútil Gugiganga". Ele pechinchou para cinqüenta sen. ${ }^{[30]}$

Fora isso, um imenso mapa regional de Paris, um pião de celulóide com quase $30 \mathrm{~cm}$. de diâmetro, uma pena especial, que produz letras mais finas que um fio de linha, todos artigos adquiridos julgando serem verdadeiros achados; o gerente porém, não se interessou e limitou-se a rir e dizer que ia embora. "Espere" - impedi-o e amontoei diversos livros diante dele. Recebi cinco ienes. A maioria dos livros da estante era livro de bolso barato comprado em sebos, razão pela qual a avaliação do penhor fora tão inferior.

Cinco ienes diante de uma dívida de mil. Esse é o resultado da minha total inaptidão para viver na sociedade. Não é coisa para rir.

Decadent? ${ }^{[31]}$, mas se não fizer assim, eu não consigo viver. Em vez de dizer isso e me criticar, é preferivel as pessoas me dizerem "Morra!". Eu agradeceria mais e me sentiria mais aliviado, mas, raramente as pessoas dizem "Morra!". Ó, vós, fariseus sovinas e precavidos!

Justiça? A essência da luta de classes não é isso? O Humanismo? Não é Grincadeira. Eu sei. Para conseguir a nossa felicidade, é necessário eliminar o outro. É para matar. Morra! - Se não é isso, o que é? $\mathcal{N a ̃ o ~ m e ~ i f u d a m ~ c o m ~ t o l i c e s . ~}$

No entanto, mesmo na nossa classe, não há um sujeito que preste. Idiotas, assombrações, avarentos, cachorros Loucos, papudos, sim senhor. Mijo-lhes das nuvens!

Morram! - Nem merecem que eu diga isso.

Guerra. A guerra do Japão é um desespero de causa.

Morrer envolvido em desespero de causa, isso não. Prefiro morrer por conta própria.

O ser humano ao mentir, com certeza, faz uma cara séria. Que tal a seriedade dos educadores de hoje? Que nojo!

Quero 6rincar com pessoas despreocupadas em merecer o respeito dos outros.

Mas essas pessoas boas sequer se dignam a brincar comigo.

Quando fingi precocidade, as pessoas comentaram que eu era precoce. Quando fingi ser indolente, as pessoas comentaram que eu era preguiçoso. Quando fingi não saber escrever romances, as pessoas comentaram que eu não sabia escrevê-los. Quando eu fingi ser mentiroso, as pessoas comentaram que eu o era de fato. Quando fingi ter dinheiro, as pessoas comentaram que eu era rico. Quando fingi ser insensivel, as pessoas comentaram que eu era um cara insensivel. Mas, quando soltei um verdadeiro grito de angústia, as pessoas comentaram que eu fingia sofrer.

${ }^{30}$ Um sen corresponde a um centésimo do iene.

31 Decadência. No final do século XIX, os decadentes procuravam o conceito técnico de desordem como uma forma diferente. Eles viviam de forma autodestrutiva. 
$\mathcal{N} a ̃ o$ nos entendemos.

Não tem saída, a não ser cometer suicídio.

Estou sofrendo. Só de pensar em terminar a vida cometendo suicídio, grito e choro.

Manfã de primavera, floresceram duas ou três flores de ameixeira e, nos seus galhos, brilhavam os raios de sol matutino. Nesse mesmo ramo, dizem que fora encontrado pendendo morto um jovem estudante de Heildeberg.

- Mamãe! Por favor, repreenda-me.

- De que modo?

- Diga que sou covarde!

- Ah, é? Covarde... já chega, não é?

Mamãe é cheia de bondade inigualável. Quando penso nela, fico com vontade de chorar. Mesmo que seja só para me penitenciar por tudo o quanto the fiz, hei de morrer.

Mamãe, me perdoe! Perdoe-me somente mais uma vez.

Os anos passam

e, cego,

o filhote de cegonha

vai crescendo:

ele vai engordando.

(Poema ensaio de Ano Novo)

Morfina, atromol, narcopon, pantopon, pabinal, panopin, atropin.

Orgulho- o que é? O que é orguโho?

As pessoas, aliás, o homem não pode viver sem pensar: "Eu sou excepcional", "Eu tenho boas qualidades"? Detesto pessoas, pessoas me detestam.

Comparações de vaidades.

Austeridade $=$ idiotice

De qualquer modo, se está vivo, não há dúvida de que está praticando fraude.

Carta pedindo dinheiro emprestado:

“A resposta.

Responda a carta, por favor.

E que ela seja, de todo jeito, de uma boa-nova.

Penso nas mais variadas humilhações, encontro-me sozinho a gemer. 
Não estou fingindo. A6solutamente.

Eu the imploro.

Sinto-me sucumbir por causa da vergonha.

$\mathcal{N a ̃ o e ́ ~ e x a g e r o . ~}$

Dias após dias, aguardo resposta, e noite e dia sou tomado de tremores.

$\mathcal{N a ̃ o ~ m e ~ f a c ̧ a ~ c o m e r ~ a r e i a . ~}$

Ouço risadas abafadas através da parede, e, até tarde da noite, fico me revirando na cama.

Não me humi lhe.

Maninha!"

Li o Diário de Yûgao até aquele ponto, coloquei-o novamente dentro da caixa de madeira, caminhei em direção à janela, escancarei-a. Ao olhar para o quintal lá embaixo, estava esbranquiçado pela chuva que caía, e depois comecei a relembrar as coisas daquela época.

Desde então, já se passaram seis anos. O vício de Naoji em entorpecentes foi o pivô para o meu divórcio. Não, não posso dizer desse modo. Ele não foi o causador da minha separação, ela foi desencadeada por outro motivo qualquer. Como foi dito uma vez, tenho a sensação de que, desde o momento do meu nascimento, já estava assim traçado. Naoji enfrentava dificuldades em saldar a dívida junto à farmácia e, freqüentemente, me pedia dinheiro. Como eu estava recém-casada com Yamaki, não tinha disponibilidade de tamanha quantia; além do mais, havia uma regra de que seria indecente emprestar o dinheiro do próprio marido, em surdina, para o meu irmão. Conversando com minha velha empregada, senhora Oseki que me acompanhara, vendi braceletes, colares e vestidos. Meu irmão mandou-me uma carta dizendo:

Me mande o dinheiro, estou sofrendo e envergonhado, não consigo nem encará-la mana, tampouco The telefonar, mande o dinheiro através de Oseß̧i no endereço onde mora o romancista Jirô Vehara, que fica no Edifício Kayano, da rua ... bloco ... de Kyôbashi, você deve conhecer, ao menos, pelo nome. O senhor Vehara tem reputação de ser imoral perante a sociedade. Com certeza, ele não é o que dizem, portanto pode confiar nele e enviar o dinheiro no referido endereço. Procedendo dessa maneira, ao recebê-lo, ele me telefonará informando da remessa. Mana, imploro-the que proceda desse modo. Eu não gostaria que o meu vício chegasse aos ouvidos da mamãe, e eu pretendo me tratar antes de notificá-la dessa minha dependência e, desta vez, com o envio do seu dinheiro, saudarei as dívidas da farmácia e depois vou-me internar na casa de campo de Shiohara. Pretendo recuperar a boa saúde e retornar ao lar; é verdade, e se eu saldar a dívida da farmácia, a partir desse dia não vou ter mais recaída. Assim peço a Deus. Mana, acredite em mim, por favor, mantenha segredo da mamãe, recorra a Oseki para a remessa do dinheiro chegar no apartamento de senhor Vehara no Edifício Kayano.

Era o que estava escrito na carta. Por intermédio da senhora Oseki, seguindo o mapa traçado por meu irmão, enviei o dinheiro, às escondidas, para o apartamento do senhor Uehara. Mas, como sempre, as promessas da carta de Naoji eram mentiras, ele não se internou na casa de campo de Shiohara e o vício com o entorpecente foi-se agravando cada vez mais. Suas frases assemelhavam-se, 
nas cartas de pedido de dinheiro, a penosos gritos de dor, e dizia que daquela vez largaria o vício, jurava e suplicava. A minha vontade era-lhe dar as costas a ele e, pensando outra vez nas suas mentiras, novamente, fui obrigada a recorrer à Sra. Oseki a fim de vender os meus broches e enviar o resultado da venda ao apartamento do senhor Uehara.

- Como é o senhor Uehara?

- Ele é baixinho, de rosto pálido, um tanto indelicado. - foi o que a senhora Oseki respondeu.

- Mas, ele raramente se encontra no apartamento. Geralmente, estão lá somente as duas, a esposa com a filha de seis ou sete anos. Essa senhora não é muito bonita, mas tem uma aparência bondosa e de bom caráter. Se for para ela, posso entregar o dinheiro com segurança.

Naquela época, comparada com quem sou agora... - nem cabe aqui a comparação - eu era totalmente diferente de hoje, era como se fosse outra pessoa, distraída, despreocupada. No entanto, com o sucessivo pedido de dinheiro, em quantias vultosas, comecei a ficar aflita. Um dia, na volta do teatro $N \hat{o}^{32}$, em Ginza, dispensei o carro, caminhei em direção a Kyôbashi, e fui visitar o apartamento do Edifício Kayano.

O senhor Uehara estava na sala sozinho lendo o jornal. Vestia um haori ${ }^{33}$ listrado de branco com azul escuro, e se assemelhava a um animal raro, nunca antes visto, e, em razão disso, ele me causou uma impressão muito esquisita, de modo que não pude deduzir sua idade.

- Minha mulher foi agora mesmo buscar a quota de mantimento

Falou com uma voz anasalada e entrecortada. Ele me tomou como amiga de sua esposa. Depois de me apresentar como a irmã mais velha de Naoji, limitou-se a sorrir, dizendo "Hum". Aquele instante, senti um calafrio, não sei por quê.

- Vamos sair? - mal proferiu a frase, já tinha colocado o nijû mawashij, retirou o tamanco da sapateira, calçou-o e saiu andando na minha frente, apressado, pelo corredor.

Era o entardecer de começo de inverno. O vento estava gelado. Dava a sensação de que vinha soprando do rio Sumida. O senhor Uehara foi caminhando calado, como se estivesse resistindo à brisa fluvial, com o ombro direito erguido, em direção ao aterro. Eu acelerei os passos atrás dele para alcançá-lo.

Nós fomos para o subsolo de um edifício erguido atrás do Teatro de Tóquio. Dentro dele, estavam quatro ou cinco grupo de clientes num cubículo comprido e estreito, de aproximadamente vinte tatami; estavam todos em suas respectivas mesas bebendo saquê silenciosamente.

O senhor Uehara começou a beber saquê em um copo. Depois, ele pediu outro para mim e me serviu a bebida. Eu bebi duas doses, mas não senti nada.

32 Teatro clássico japonês.

33 Espécie de casaco.

34 Sobretudo para inverno. 
Ele bebeu saquê, fumou e, o tempo inteiro, permaneceu calado. Pela primeira vez na vida, eu me encontrava num lugar como aquele, mas estava calma e me sentia muito bem.

- Seria bom que ele bebesse bebida alcoólica.

- Como?

- Refiro-me a seu irmão. Seria melhor que ele mudasse para álcool. Antigamente, eu também fui viciado em entorpecentes, e aquilo deixa as pessoas aterrorizadas. O álcool também tem a mesma reação, mas, de certa forma, é tolerado pela sociedade. Vamos transformar o seu irmãozinho num beberrão, o que me diz?

- Uma vez, eu vi um bêbado. Foi no Ano-Novo, quando eu ia saindo de casa. Um conhecido do nosso chofer estava dormindo e roncando no banco de passageiros. Sua face estava tão vermelha que parecia a de um diabo. Quando eu o vi naquele estado, soltei um grito e o meu motorista me disse: "Esse cara é um beberrão incorrigível!". Depois de retirá-lo do carro, ele carregou-o nos ombros e levou-o a algum lugar. O bêbado estava tão maleável que era como se não tivesse ossos. Mesmo assim, ele resmungou algo; foi nessa ocasião em que, pela primeira vez, eu vi um bêbado. Foi divertido.

- Eu também sou beberrão.

- Ora, mas é diferente, não?

- Você também é uma beberrona.

- Nada disso. Eu não sou. Eu já vi bêbados. Sou totalmente diferente.

Pela primeira vez, o senhor Uehara riu alegremente.

- Sendo assim, talvez seu irmãozinho não possa ser um bêbado. Bem, de qualquer modo, é melhor ele mudar para bebida alcoólica. Vamos embora. Se ficar muito tarde, é complicado para você, não?

- Não, não se incomode.

- Não, na verdade ... eu é que fico em apuros. Mocinha, a conta!

- Seria muito alta? Se for pouco, eu tenho.

- Ah, é? Então, você paga a conta.

- Pode ser que falte.

Eu olhei para dentro da minha bolsa, para me certificar da quantia existente, e depois notifiquei o senhor Uehara.

- Puxa! Se você tem tudo isso, dá para nós bebermos em mais dois ou três bares. Você está caçoando de mim.

O senhor Uehara franziu as sobrancelhas e sorriu. seriedade:

- Vamos beber em outro lugar? - mal perguntou, ele sacudiu a cabeça com

- Não, já é suficiente. Eu lhe arranjarei um táxi, volte para casa. 
Nós subimos as escadarias escuras do subsolo. O senhor Uehara estava um degrau acima de mim quando, no meio da escada, ele se virou rapidamente e me beijou. Recebi o beijo com os lábios cerrados.

Não é que eu estivesse gostando do senhor Uehara, assim mesmo, a partir desse momento, passei a ter um "segredo". Toc, toc, toc, ele foi subindo as escadarias, tive um sentimento estranho; subi vagarosamente atrás dele. Lá fora, a brisa fluvial batendo no rosto era agradável.

Após ele ter chamado o táxi, nós nos separamos sem nada dizer.

No sacolejar do carro, tive a sensação de que o mundo se tornara amplo como um oceano.

- Tenho um namorado. - Certo dia, fui assaltada pela melancolia por receber críticas do meu marido e, de repente, disse aquilo.

- Estou sabendo. Na certa, é o tal de Hosoda, não é? Não consegue esquecê-lo, não é?

Fiquei calada.

Esse problema surgia toda vez que aconteciam coisas desagradáveis entre nós. Pensei comigo mesma que não dava mais. É como se cortasse de maneira inadequada um tecido novo para um vestido, e não houvesse como remendar o corte errôneo, a não ser jogando fora e reiniciando tudo com tecido novo.

- Não vá me dizer que esse filho na sua barriga...

Certa noite, ao ser questionada por ele sobre a criança, não conseguia parar de tremer de tanto pavor. Pensando agora, eu e meu marido éramos jovens. Eu nem conhecia o amor. Nem mesmo afeição eu sabia o que era. Fiquei extasiada com os quadros que o senhor Hosoda pintava e dizia para todo mundo que, se eu me tornasse sua mulher, seria maravilhoso passar os dias a seu lado, e que se não me casasse com uma pessoa de tão bom gosto quanto o dele, meu casamento seria algo insignificante. Por isso fui mal interpretada por todos. Mesmo assim, sem conhecer amor nem afeição, corajosamente admiti gostar do senhor Hosoda, e não me esforcei para desmentir. As coisas foram se complicando e até o bebê que adormecia no meu ventre ficou sendo alvo de suspeitas do meu marido. Ninguém falava abertamente sobre o divórcio, mas a indiferença foi crescendo irremediavelmente entre nós, e a separação foi inevitável. Eu retornei para a casa materna em companhia da senhora Oseki. Depois, o bebê nasceu morto, adoeci e fiquei acamada, e cortei relações com Yamaki para sempre.

Naoji parecia sentir-se responsável pelo meu divórcio e teimou em dizer: "Vou me matar!"; começou a chorar aos gritos, desesperadamente, a ponto de seu rosto transfigurar-se. Perguntei em quanto estava o montante da dívida na farmácia: era estratosférico. Além disso, mesmo aquela cifra eu soube mais tarde que ele havia inventado, sem coragem de dizer-me a verdade. A importância exata atingia quase 0 triplo do que ele me confessara na ocasião.

- Encontrei-me com o senhor Uehara. É uma boa pessoa, não? Que tal, a partir de agora, ir beber com ele? Bebida alcoólica não é uma coisa barata. Se precisar de dinheiro, posso até lhe arranjar. Não se preocupe com a dívida da farmácia, eu darei um jeito. 
O fato de eu ter-me encontrado com o senhor Uehara e tê-lo elogiado, parece ter deixado Naoji muito feliz e, naquela noite, o mano saiu para se encontrar com ele, levando o dinheiro que eu the havia dado.

O vício, talvez seja, na verdade, uma doença de espírito. Elogiei o senhor Uehara, depois tomei emprestado de meu irmão alguns de seus livros. Ao lê-los, concluí: "Como ele é notável!". Replicou-me, então: "A mana não é capaz de entendê-lo". Mesmo assim, demonstrou alegria e, pegando outro livro da autoria do senhor Uehara, entregou-o a mim, dizendo: "Experimente ler este". Nesse ínterim, eu também comecei a me interessar pelos romances do escritor e nos tornamos seus assíduos leitores e fazíamos comentários a respeito da sua obra. O mano ia orgulhoso todas as noites à sua casa. E, conforme o plano do escritor, Naoji, aos poucos, parece que foi transferindo o seu vício para o álcool.

Ao consultar mamãe, privadamente, a respeito do montante da dívida da farmácia, ela cobriu o rosto com uma das mãos, permaneceu imóvel e calada, assim, por longo tempo. Depois, ergueu o seu rosto, sorriu e, com ar melancolico, disse: "Não adianta ficar pensando, não é? Não sei quanto tempo levaremos para saldar a divida, mas iremos pagando mensalmente, em pequenas parcelas".

Desde então, já se passaram seis anos.

Yûgao. Ai, o mano também deve sofrer. Além do mais, com os caminhos interrompidos, ele deve estar se remoendo em dúvida quanto à direção a tomar. Talvez ele esteja bebendo todos os dias, pensando em morrer.

E se, sem pestanejar, ele se tornasse um verdadeiro libertino? Se assim procedesse, não se sentiria ele mais feliz? Haveria, acaso, uma pessoa que não fosse libertina? Assim estava escrito naquele caderno, mas, se me dissessem tal coisa, eu também seria uma libertina, o tio Wada também, e até a mamãe seria uma libertina. Libertino não seria o mesmo que gentil? 


\section{Capítulo IV}

\section{Primeira carta de Kazuko para Uehara}

Hesitei muito em escrever-lhe. Mas, hoje de manhã, lembrei-me repentinamente das palavras de Jesus: "Sede prudentes como as serpentes, e simplices como as pombas". Foi então que resolvi escrever-lhe esta carta, levada por uma estranha coragem. Sou a irmã mais velha de Naoji. Será que o senhor me esqueceu? Se já me esqueceu, por favor, tente lembrar-se.

Peço desculpas por $\mathcal{N} a o j i$ ter causado transtorno em sua casa outro dia. (NNa verdade, o que ele fez diz respeito somente a ele e tenho a impressão de que o meu pedido de desculpas parece um nonsense). Hoje eu gostaria de The fazer um pedido, em prol da minha pessoa, não para $\mathcal{N}$ aoji. Disse-me ele que houve um incêndio em seu apartamento de Kyôbashi, o que fez mudar-se para a atual residência. Pensei em visitá-to no subúrbio de Tóquio. Como ultimamente a saúde de mamãe tem piorado, fiquei impossibilitada de ir à capital em decorrência de sua fragilidade, e, por essa razão, resolvi escrever-the.

Há um assunto sobre o qual gostaria de consultá-lo.

Do ponto de vista da filosofia dos "Altos conhecimentos para mulheres" [35], que vim adotando até agora, essa consulta poderia até soar má e até criminosa, mas eu, não, nós - tenho a impressão de que nós não podemos continuar levando essa vida. Eu gostaria que o senhor - a quem o mano $\mathcal{N}$ aoji mais respeita nesse mundo - se inteirasse dos meus reais sentimentos e me aconselhasse.

Para mim, esta vida está se tornando insuportável. Não se trata de uma questão de gostar ou não - do jeito que está, não poderemos, nós três, mãe e filhos, continuar a viver.

Ontem mesmo eu senti o meu corpo febril, a respiração ofegante, estava até difícil de eu mesma me suportar; nisso, logo após o almoço, so6 a chuva, a mocinha, filha do agricultor lá de baixo, trouxe arroz, carregando-o em suas costas. Eu, de acordo com o combinado, paguei-The a mercadoria com roupas. A mesma mocinha sentou-se à minha frente, na sala, servindo-se de chá, e perguntou-me com sinceridade:

- Escute, por quanto tempo você poderá viver vendendo as suas coisas?

- Mais ou menos meio ano ou talvez um ano. - respondi-lhe. E, escondendo o rosto com uma das mãos, disse-lhe:

- Estou com sono. Estou morrendo de sono.

- Você está cansada. Deve ser um tipo de esgotamento nervoso que causa sono.

- É, talvez seja isso mesmo.

Eu estava prestes a chorar, e de repente emergiram dentro do meu peito as palavras "realismo" $e$ "romantismo." Em meu interior, não existe realismo. Do jeito como estou, conseguirei continuar viva? Ao pensar nisso, senti um calafrio pelo corpo todo. Mamãe está debilitada, ora se levanta, ora se deita, e o mano, como sabe, é doente de espirito. Seu estado é grave e, quando está por aqui, freqüenta assiduamente a pensão restaurante da redondeza a fim de beber shôchiu. A cada três dias, pega o dinheiro da venda das nossas roupas e parte para Tóquio. Mas não é isso o que me faz sofrer. O meu temor é que a minha existência diária se deteriore por si só, abandonada, similar à folha de bashô (variedade de bananeira ornamental do Japão) que apodrece no próprio pé, sem cair. E por essa razão que eu queria tanto escapar dessa vida

35 Onna Daigaku - Manual de comportamento social feminino do período Edo (1867). 
ordinária, ainda que, para isso, seja obrigada a violar as regras dos "Altos conhecimentos para mulheres". Sendo assim vim pedir o seu conselho.

Eu gostaria de deixar bem clara a minha posição para minha mãe e meu irmão. Queria explicitar a eles que há muito amo certa pessoa e que, no futuro, pretendo viver em sua companfia, como amante. Essa pessoa, por certo, o senhor a conhece. Suas iniciais são: $\mathcal{M}$ e C. Desde muito tempo atrás, quando ocorre algo ruim, anseio muito ir voando ao seu encontro, devorada pelas chamas da paixão.

M. C. tem, como o senhor, esposa e filho. Além do mais, parece que possui diversas amigas mais jovens e bonitas do que eu. Sinto, no entanto, que não tenho outro caminho na vida, senão ir ao encontro de M. C. Ainda não encontrei sua esposa, mas me parece uma pessoa bondosa e gentil. Ao pensar nessa meiga esposa, penso no quanto sou má. Contudo, minha vida atual é mais horrorosa ainda e não consigo parar de pensar em me apoiar em $\mathcal{M}$. C., e penso em concretizar o meu amor "símplice como a pomba e prudente como a serpente." Certamente, nem mamãe, nem o mano, nem as pessoas da sociedade me apoiarão. $\mathcal{E}$ o senhor, o que acha? Eu não tenho outra saída senão raciocinar e agir sozinha. Só de pensar nisso, meus olhos se enchem de lágrimas. Como se trata de algo que faria pela primeira vez na minha vida, penso se não haveria algum meio de solucionar esta difícil questão com a aprovação de todos. Assim, como se estivesse a cuidar de um problema de álgebra, começo a sentir, por vezes, que existe em algum lugar um ponto por onde a questão se desembaraça e se soluciona com facilidade, e repentinamente fico eufórica.

Entretanto, o que estará pensando M. C.? Mas o que é que me importa? Desanimo-me quando penso nisso. $\mathcal{N a}$ verdade, sou, por assim dizer, uma "esposa forçada ..." $\mathcal{N}$ ão, não posso definir-me como esposa forçada, talvez pudesse dizer "amante forçada ..." e se acaso $\mathcal{M}$. C. não me quiser em hipótese nenhuma, ficará por isso mesmo. Por isso peço-the esse favor. Peço-The que pergunte a ele. Certo dia, há seis anos, apareceu um delicado e fosco arco-íris em meu peito e, embora não se tratasse de paixão, nem amor, à medida que os meses iam passando ele foi perdendo a indefinição e adquirindo uma coloração mais vívida. Até hoje, nunca o perdi de vista. O arco-íris que desponta no céu, após o entardecer chuvoso, tem existência efêmera e logo se desvanece; por outro lado, o arco-íris que brota no coração da gente tem existência duradoura. Por favor, peço-The que o interpele. Sinceramente, o que ele estaria pensando sobre mim? Será que ele me toma por um arco-íris pós-chuva, que desapareceu há muito tempo?

Se for assim, eu também preciso apagar o meu arco-íris. Porém, sinto que o arco-íris do meu coração não se dissipará enquanto eu não terminar com a minha vida. Estou orando por uma resposta.

$$
\text { Ao Sr. Jirô Vehara (Meu Chekhov. }{ }^{[36]} \text { My Chekhov. M. C.). }
$$

P.S.: Vltimamente, tenho engordado pouco a pouco. Acho que me transformei numa mulher mais humana do que uma pessoa animalesca. Neste verão, eu fi somente um romance de $\mathcal{D}$. H. Lawrence. ${ }^{\text {[3] }}$

\section{Segunda carta}

Como não obtive resposta, escrevo-the outra carta. $\mathcal{N a}$ que the enviei outro dia o senhor deve ter percebido todas as minhas artimanhas venenosas. $\mathcal{N a}$ verdade, esgotei todos os meus ardis em cada uma das linhas daquela carta. No fim das contas, o senhor deve ter pensado que seria uma carta pedindo ajuda

36 Anton Pavlovich Chekhov (1860-1930), romancista e dramaturgo russo. Escreveu a peça teatral $O$ jardim das cerejeiras, baseada na decadência da nobreza russa. Ele é aclamado em toda a Rússia como um escritor que descreveu a sociedade moderna.

37 David Herbert Lawrence (1885-1930), escritor inglês. Escreveu obras baseadas na psicologia do amor, da paixão, e do espírito, como $O$ amante de lady Chaterley e $O$ filho e a amante. 
financeira. Até que eu não negaria essa intenção, mas, no fundo, com o perdão da palavra, caso eu quisesse ter apenas um defensor, a minha escolha não recairia sobre o senhor. Tenho impressão de que por aí há muitos velhos ricos que cuidariam de mim com carinho. Outro dia, mesmo, eu recebi uma proposta de casamento. O nome dessa pessoa o senhor deve conhecer, mas trata-se de um senhor de seus sessenta e tantos anos, que vive só, membro de qualquer coisa, de um não sei o quê de artes, um grande mestre. Esse dito mestre veio até esses confins para me pedir em casamento. Ele morava perto da nossa casa em Nishikata, no tempo da minha infância; como nós pertencíamos à sociedade e éramos amigos de 6airro, encontrávamo-nos esporadicamente. Certo dia, Cembro-me de que foi no entardecer de um outono, eu e mamãe, passamos de carro em frente à sua casa, e ele lá estava em pé distraído, sozinho ao lado da entrada. Quando mamãe o cumprimentou pela janela do carro, o rosto grave e pálido do mestre avermelhou-se de repente, como uma folha de bordo.

- Seria amor? - Eu irrompi animadamente.

- Ele gosta da senhora, não é?

Mas ela me disse serenamente:

- Não, senhora. É uma pessoa importante.

Ela me falou, como se fosse monólogo. Parece que está na nossa tradição familiar respeitar os artistas.

Esse mestre, que havia perdido a esposa no ano anterior, apresentou à mamãe a proposta de casamento por intermédio de um amigo da nobreza que fazia parte do grupo de Tengu ${ }^{[38]}$ de Yôkyoǩu de tio Wada. Mamãe me sugeriu: "Por que você mesma não đá a resposta diretamente a ele?". Eu, sem pestanejar, recusei sua proposta, alegando que não tinha intenção de me casar. Consegui escrever isso sem qualquer hesitação.

- Eu posso recusar, não posso?

- Claro que pode... eu também achava que não daria certo.

Como o senhor mestre se encontrava na casa de campo de Karuizawa, enviei a carta-resposta para aquele endereço. Nisso, passados dois dias, ainda sem conhecimento da carta, o próprio mestre apareceu, sem avisar, em nossa casa, sem saber da minha resposta. Ele estava de passagem para as termas de Izu, por motivo de trabalho. Parece que esses ditos artistas, não importa a idade, agem arbitrariamente, feito crianças.

Como mamãe estava mal, eu o atendi, ofereci-lhe chá na sala chinesa, e the disse:

- Olhe... a respeito da carta de recusa, creio que ela já deve ter chegado a Karuizawa, eu refleti muito a respeito, mas...

- Ah, é? - Respondeu-me afobadamente, enxugando o suor com o lenço.

- Mas, por favor, reflita 6em, mais uma vez. Não sei o que dizer, e nem sei como me expressar, talvez eu não possa oferecer-The a felicidade espiritual, mas, em contrapartida, posso the suprir de bens materiais, que the proporcionem certa felicidade. Isso eu posso the assegurar, com toda a franqueza.

- $\mathcal{N a ̃ o ~ e n t e n d o ~ m u i t o ~ b e m ~ o ~ s i g n i f i c a d o ~ d o ~ q u e ~ s e j a ~ e s s a ~ f e l i c i d a d e . ~ D e s c u l p e - m e ~ p e l o ~ a t r e v i m e n t o . ~}$ Uma vez, não havia escrito Chekhov em sua carta endereçada à esposa: "Dê-me um filho, façamos nosso filho"? Havia também, num ensaio de $\mathcal{N i e t z s c h e ~}{ }^{[39]}$, palavras como: "MMlher com quem gostaria de ter um filho". Eu quero ter um filho. A mim não importa essa tal de felicidade. Quero dinheiro também, mas ter o necessário para poder educar a criança é o suficiente para mim.

${ }^{38}$ Um ser imaginário de nariz grande que habita nas montanhas. Canto clássico de Nô do Japão.

39 Friedrich Wilhelm Nietzsche (1844-1900), pensador e filósofo alemão. 
O mestre riu de modo estranho.

- Você é uma pessoa atípica. Consegue dizer o que pensa, não importa a quem. Em sua companfia, quem sabe, talvez eu tivesse novas inspirações.

Ele falou num tom de orgulho, que nada combinava com a sua idade avançada. Se eu pudesse, com todas as minhas forças, renovar o trabalho de um artista tão importante - pensei - me sentiria reconfortada, mas, por outro lado, era impensável ter o meu corpo abraçado por aquele velho mestre.

- Não se importaria se eu não o amasse?

Perguntei-o com um sorriso, e ele respondeu-me sério:

- As mulheres não precisam amar. As mulheres podem viver sem se preocupar com nada.

- Mas... uma muโher feito eu, com certeza, não posso nem imaginar estar casada com uma pessoa sem amor. Afinal, já sou adulta. No próximo ano completo trinta anos.

Disse isso sem pensar. Quando atinei, já era tarde.

Trinta anos. Lembrei-me das palavras de um romance francês que havia lido antigamente, que dizia que até os vinte nove anos ainda resta na mulher o aroma da virgem. Mas, no corpo de uma mulher de trinta anos, não mais resta aroma de virgem em parte alguma. De repente, fui tomada por uma profunda melancolia. Ao olhar para fora, o mar refletia os raios de sol do meio dia e brilhava intensamente como cacos de vidro. Ao ler aquele romance, acabei convencendo-me de que aquilo que estava escrito tinha um quê de verdade. Tenho saudades daquela época em que acreditava que a vida de uma mulher acabava aos trinta. Pulseira, colares, vestidos, obi ${ }^{[40]}$, à medida que essas coisas foram desaparecendo, ao redor do meu corpo, uma após outra, o aroma de virgem também foi se desvanecendo do meu corpo. Mulher de meia idade, além de tudo, pobre. Ai, que desgosto. Mas, mesmo na vida de uma muโher de meia idade, ainda há com certeza presença da mulher. Foi só ultimamente que comecei a entender. Lembro-me de quando eu tinha dezenove anos, uma professora inglesa me disse, antes de regressar à sua pátria:

- Você não deve amar. Se amar, será infeliz. Se quiser amar, faça-o quando estiver mais madura. Ame aos trinta anos.

Diante dela, fiquei sem compreender nada. Nessa época, não fazia a mínima idéia das coisas que faria quando chegasse aos trinta anos.

- Ouvi rumores de que venderão esta casa.

O mestre, de repente, interpelou-me com um semblante maldoso.

Comecei a rir.

- Me desculpe, lembrei-me de O jardim das cerejeiras ${ }^{[41]}$. É o senhor que irá comprá-la, não é?

O mestre mostrou-se sensibilizado e ficou evidente o seu interesse, fez-se de zangado e entortou a boca, calando-se. Na certa, o mestre deve ter ouvido rumores de que certo príncipe estaria interessado em adquirir o imóvel por quinhentos mil ienes novos, mas o assunto não passou de 6oato. Contudo, o mestre, ao ser comparado com o personagem Lopaßfhin de O jardim das cerejeiras, pareceu ter perdido o 6om humor, comentou mais sobre alguns assuntos corriqueiros e foi-se embora.

O que estou procurando agora não é Lopaßfhin. Isso eu posso the garantir. Aceite somente a oferta feita por uma mulher de meia idade.

${ }^{40}$ Faixa para quimono. Conforme o tecido, pode ser de valor elevado.

${ }^{41}$ Jardim das Cerejeiras (Vishnjouyi sad, 1903), peça teatral de Chekhov. O servo Lopakhin compra a propriedade chamada Jardim das Cerejeiras, pertencente à nobre dama Lanefuscaia, após a queda da aristocracia. 
Já se passaram seis anos desde que me encontrei com o senfor pela primeira vez. Naquela ocasião, eu não sabia nada sobre sua pessoa. Apenas achei que fosse uma má influência de mestre sobre o meu irmão. $\mathcal{E}$, depois, tomamos um copo de saquê juntos e, depois, me fez uma pequena travessura, não foi? Mas, eu me mantive indiferente. Tive a sensação de ter me tornado mais leve. Nãa gostei e nem desgostei do senhor. Entrementes, a fim de agradar o mano, tomei emprestados diversos livros dele, da sua autoria. Eu os li, achei alguns interessante e outros não, não cheguei a ler com ardor. No período desses seis anos, não sei precisar a data, só sei que o senhor havia penetrado no meu peito como uma névoa. O que fizemos naquela noite na escadaria do subsolo veio à minha memória repentinamente, de modo nítido e vívido, como se aquele acontecimento fosse a coisa mais importante que determinasse o meu destino. Senti imensas saudades do senhor e me indaguei, com o coração apertado, se seria amor. Indefesa, chorei. O senhor difere totalmente de outros homens. Eu não estou amando um escritor, feito a Nina do $\mathcal{A}$ Gaivota ${ }^{[42]}$. Não estou apaixonada por um romancista. Eu ficaria embaraçada se o senhor pensasse que sou uma garota apaixonada pela literatura. O que quero é ter um filho seu.

Muito antes, quando o senhor era solteiro, e eu também não estava casada com Yamaki, talvez não sofrêssemos tanto se, tivéssemos nos casado; mas eu já me conformei com o fato de não poder desposá-lo. Abandonar sua esposa me parece um ultraje sórdido, algo em que me recuso a pensar. Eu seria sua amante (recorro a essa palavra com muito desgosto, contudo, não adianta me chamar de namorada. Falando vulgarmente, não passaria de uma amante), assim mesmo, não me importa. A vida comum de uma amante na sociedade parece árdua, não é? Pelo que dizem, descartam-na quando não a querem mais. Dizem que todos os homem, ao se aproximarem dos sessenta anos, retornam para as suas legítimas esposas. Portanto, não é para ser amante de ninguém, assim ouvi dizer uma vez na conversa entre um velho empregado e uma pajem em $\mathcal{N}$ ishikata. Mas isso se refere a amantes comuns. Sinto que, no nosso caso, seria diferente. Eu penso que, para o senhor, a coisa mais importante é o seu trabalho. Sendo assim, caso o senhor me ame, ficarmos juntos seria 6om para o seu trabalho. Assim sendo, sua esposa também entenderá a nossa situação. É uma estranha teoria da perversão, mas, no meu modo de pensar, acho que não há nenhum erro.

A questão é somente a sua resposta. Se o senhor gosta de mim, se desgosta, ou se the sou indiferente. Tenho muito medo, mas essa resposta, eu preciso saber. Outro enviei-Che uma carta sobre ser "amante oferecida," e nesta outra, escrevi "mulher de meia idade oferecida;" mas ao refletir bem, agora, se eu não obtiver a resposta da sua parte, não terei nenhum indício de sua anuência, e nesse caso só me restaria ir definhando sozinha e abandonada. E, também, não havendo concordância da sua parte, o meu trabalho será em vão.

De repente, veio à minha mente que, sendo o senhor um romancista, escreve muito sobre aventuras amorosas. Tem-se aventado entre os leitores de que o senhor é uma pessoa má, mas, na realidade, é uma pessoa bem equilibrada, não? Eu não sei o que seria uma pessoa equilibrada. Pelo meu conceito, viver bem fazendo o que é prazeroso, isso é que me importa. Quero ter um filho seu. Filho de outrem não me interessa, haja o que houver. Por isso estou pedindo a sua opinião. Caso me compreenda, responda-me. Expresse-me todo o seu sentimento claramente.

Parou de chover e começou a ventar. Agora, são três horas da tarde. Irei buscar a quota de distribuição de saquê especial. Dentro de dez minutos, irei à aldeia de baixo, levando comigo duas garrafas de rum na sacola, e essa carta, carrego-a no bolso do peito do meu sobretudo. Esse saquê, eu não permitirei que o mano o beba. Sou eu mesma que o beberei. Todas as noites tomarei um gole no copo. $\mathcal{N} a$ verdade, o saquê não é para ser degustado em copos? Não quer vir para cá?

Para Sr. M. C.

42 Chaika ( A Gaivota, 1896), peça teatral de Anton Chekhov. Nina é a personagem principal que se apaixona por um famoso escritor, Trigorin. Após ser abandonada por ele, Nina trilha caminhos difíceis. No fim, Trigorin se mata. 


\section{Terceira carta}

Hoje também o tempo ficou chuvoso. Está caindo uma garoa fina quase invisível. Todos os dias permaneço em casa à espera de uma resposta e, no entanto, até hoje não recebi nenhuma notícia sua. Afinal, o que estaria pensando o senhor? Será que eu não deveria ter escrito a carta a respeito daquele mestre? "Escrever sobre a proposta de casamento, despertando em mim o espirito de competição". Teria o senhor pensado assim? Mas, aquela proposta de casamento do mestre ficou por isso mesmo. Agora há pouco, estive conversando com a mamãe sobre isso, e nós rimos. Outro dia, mamãe se queixava de que a ponta da sua língua estava dolorida, contudo, ultimamente, ela tem se mostrado um pouquinho melhor, graças ao tratamento receitado pelo $\mathcal{N}$ aoji.

Há poucos instantes, eu contemplava da varanda a garoa, a fazer redemoinhos, meditando a respeito dos seus sentimentos. Mamãe me chamou à sala de jantar.

- Kazuko, venha tomar o leite quente. Esquentei bem devido ao frio.

Enquanto tomávamos o leite fumegante, conversamos sobre a proposta daquele mestre.

- A senhora não acha que aquele senhor e eu não temos nada em comum?

Ela me respondeu imperturbável.

- Sim, vocês não têm nada a ver.

- Eu sou egoísta desse jeito. Além disso, não desgosto dos artistas, e ele parece ter uma renda alta. Creio que, nessas condiçães, não seria tão mal casar com uma pessoa como ele. No entanto, não dá!

Mamãe riu e disse:

- Kazuko, você não tem jeito. Você diz que não o tolera, mesmo assim ficou de prosa alegremente com ele durante muito tempo. Eu não entendo os seus sentimentos.

- Ora, mas estava divertido. Gostaria de ter conversado sobre diversos assuntos. Acho que não tenho decência, não é?

- Não, você é manhosa, Kazuko é manhosa demais.

Mamãe estava de bom humor hoje.

Após reparar nos meus cabelos, que eu havia prendido no dia anterior, comentou:

- Esse tipo de penteado combina com pessoas que têm pouco cabelo. Não é o seu caso, fica majestoso demais, fico com vontade de colocar uma pequena coroa de ouro. Nãa ficou bem.

- Estou desapontada. Pois não foi a senhora mesma que disse uma vez que minha nuca era branca e linda e que eu deveria fazer o possivel para não escondê-la?

- Você se lembra somente dessas coisas, não é?

- Nunca me esqueço dos elogios. É agradável lembrá-los.

- Pois é, outro dia, você foi elogiada por aquela pessoa, não foi?

- É verdade. Por isso fiquei manhosa. Ele disse que em minha companhia a inspiração brota... ai, que coisa insuportável. Não é que eu não goste de artistas, mas não agüento pessoas com ar de dignidade como se fossem homens de caráter.

- Que tipo de homem é o mestre de $\mathcal{N} a o j i$ ?

Senti um calafrio.

- Não sei ao certo, mas se ele é o mestre de $\mathcal{N} a o j i$ deve ser um libertino notório. 
- Notório? - murmurou ela, com os olhos irradiando alegria.

- Que palavra engraçada. Se é notório, é melhor porque é confiável, não é? Até que pode ser gracioso, pois ele fica parecido com um gatinho com o sino atado em seu pescoço. Eu tenho medo de libertinos não notórios.

- Será?

Sentia me feliz, tão feliz que era como se o meu corpo tivesse se transformado em fumaça e levitasse em direção ao céu. O senhor compreende por que fiquei tão feliz? Se não compreender... vou-the dar um murro.

$\mathcal{N} a ̃ o$ quer vir realmente até aqui um dia? Pedir ao $\mathcal{N} a o j i$ para trazê-lo seria um tanto forçado e estranho, então o senhor poderia passar por aqui, como que por acaso; poderia vir acompanhado de $\mathcal{N}$ aoji, mas gostaria que viesse sozinho e, de preferência, na ausência do mano, quando ele estiver em Tóquio. Se ele estiver aqui, com certeza vai tirá-lo de mim e carregá-lo para a casa de senhora Osaki, a fim de beber shôch $\hat{u}$ e ficariam por lá mesmo. Na minha casa, sentir atração pelos artistas parece ser uma coisa hereditária. Por exemplo, o pintor Kôrin ${ }^{[43]}$, antigamente, permaneceu longo tempo em nossa casa de Quioto e produziu uma bela pintura no fusuma ${ }^{[44]}$. Portanto, creio que mamãe apreciará a sua visita. Provavelmente, o senhor ficaria acomodado no quarto de hóspedes em estilo ocidental, no andar de cima. Por favor, não se esqueça de deixar a luz apagada. Pegarei uma pequena vela acesa numa das mãos e subirei as escadarias, no escuro... não posso fazer isso? Seria precipitado, não é?

Eu adoro os libertinos. E, acima de tudo, adoro os libertinos notórios. Além do mais, eu também gostaria de ser uma libertina notória. Pressinto que, se não agir dessa forma, não poderei continuar vivendo. E o senhor não é o libertino mais notório do Japão? E, depois, por outro lado, muita gente chama-o de imundo, imoral, e o ofende com ódio explícito - isso eu escutei do meu irmão-, e, desde então, comecei a gostar ainda mais do senhor. Conhecedora de sua fama, com certeza o senhor deve ter muitas amigas, mas, com o passar do tempo, ficará gostando somente de mim. Não sei por que eu tenho essa convicção. Além disso, vivendo comigo, o senhor terá mais disposição para enfrentar o trabalho todos os dias. Desde pequena, eu ouço as pessoas dizerem a meu respeito: "Estando em sua companfia, esqueço o sofrimento". As pessoas sempre gostaram de mim. Todos me diziam que eu era uma boa menina. Por isso, penso que o senhor também não terá motivos para não gostar de mim.

Seria 6om se nós nos encontrássemos. Já não me importa mais a resposta, nem nada. Quero me encontrar com o senhor. Se eu pudesse ir a Tóquio, à sua residência, resolveria o problema da maneira mais simples; é que mamãe está mal e, sendo eu sua empregada e enfermeira permanente, não posso deixá-la sozinha. Suplico-The. Peço-The que venha até aqui. Quero vê-lo, nem que seja uma única vez. E, depois, tudo ficará esclarecido nesse encontro. O senhor precisa constatar as pequenas rugas nos cantos da minha boca. Peço-lhe que repare nelas, como sendo a infelicidade do século. Qualquer palavra que eu pronuncie agora será inútil, porque a prova maior está no meu rosto, penso que o senhor, ao vê-las, se enternecerá.

$\mathcal{N a}$ primeira carta enviada, eu The escrevi sobre um arco-íris que apareceu em meu peito, mas, esse arco-íris não é delicado e belo como o brilho do vagalume ou das estrelas. Se fosse tão vago e longínquo, eu não estaria sofrendo desse jeito $e$, aos poucos, poderia ir esquecendo o senhor. O arco-íris do meu peito é como uma ponte de chamas. É um sentimento crepitante que arde no meu peito. Nem um viciado em entorpecente, quando falta o produto, se angustia e sofre tanto quanto eu agora. Não estou agindo erroneamente. Às vezes me pergunto se estou prestes a cometer uma tolice e arrepiam-me até os fios do cabelo. Às vezes me pergunto se já não enlouqueci, esse sentimento me assola sempre. Mas ainda tenho momentos de lucidez. Sinceramente, gostaria que o senhor viesse para cá. Poderá vir quando quiser. Estarei esperando a qualquer momento. Acredite-me.

43 Ogata Kôrin (1658-1716), meados do período Edo. Pintor de Quioto.

44 Porta corrediça de papel, que tem como finalidade separar cômodos. 
Quero encontrá-lo mais uma vez e, se não the agradar, diga-me claramente. A chama do meu peito foi o senhor quem me ateou, portanto, é obrigação sua apagá-la. Com o meu próprio esforço, serei incapaz de extingui-la. Alcançarei a salvação se nós nos encontrarmos. O que estou expondo agora seria a coisa mais natural do mundo se vivêssemos na época de Man'yôshûu ou Genji Monogatari ${ }^{[45]}$. Meu desejo: tornar-me sua amante e ser de mãe de um filho seu.

Se houver alguma pessoa que zombe dessa carta, será uma que menospreza os esforços de uma mulher que procura apenas viver. Será alguém que faz escárnio da vida de mulher. É insuportável o ar estagnado de um porto, e mesmo que haja tempestade no mar, eu quero içar a vela. A vela recolhida é feia. As pessoas que zombam de mim são como as velas recolhidas de um 6arco. Elas não são capazes de enfrentar nada.

Mulher problemática. Quem mais está sofrendo com tudo isso sou eu. O espectador que não sofre nem um pouco com esse problema e que se limita somente a criticar, com as velas recolhidas, demonstra um grande contra-senso. SNão gosto que me atribuam gratuitamente esta ou aquela ideologia. Eu não tenho nenhuma ideologia. SNão agi nenhuma vez de acordo com qualquer ideologia ou filosofia.

Eu sei que as pessoas consideradas boas e respeitadas pela sociedade são mentirosas e falsas. $\mathcal{N a ̃ o}$ acredito na sociedade. Somente os libertinos notórios são meus afiados. Libertinos notórios. $\mathcal{N a}$ cruz deles eu poderia morrer crucificada. Mesmo censurada pela multidão, ainda assim, eu seria capaz de retrucar: "Vocês não passam de libertinos desconhecidos muito mais perigosos".

\section{Compreendeu?}

Para o amor não existem razões. Eu acabei me excedendo em argumentos. Além disso, tenho a impressão de que não passaram de imitação das palavras do mano. O fato é que fico no aguardo da sua visita. Quero encontrá-lo mais uma vez. É somente isso.

Esperar. Na vida da gente, ah! diversos sentimentos se mesclam, como alegria, ira, tristeza, ódio; todavia, esses sentimentos constituem apenas um por cento de nossas vidas; e os noventa e nove por cento restantes... não the parece que o ser humano vive a vida simplesmente esperando, esperando que os passos da felicidade ecoem no corredor, com ansiedade tal que chega a dilacerar o seu peito vazio? Ai, como a vida é miserável! Enfrentar essa realidade é pensar que era melhor nem ter nascido. E, assim, esperar em vão, todos os dias. É miserável demais. Ah, eu gostaria de saudar a vida, os homens, a sociedade, dizendo que vale a pena ter nascido.

Nós não poderíamos deixar de lado a moralidade?

Para M. C. (Nã̃o são iniciais de My Chekhov. NNão estou amando o escritor, My Child).

45 Man'yôshû, (Coletânea das Dez Mil Folhas), do século VIII, é a mais antiga antologia poética do Japão. Genji Monogatari (Narrativas de Genji) foi escrito pela dama da corte Murasaki Shikibu no século XI. 


\section{Capítulo V}

No verão deste ano, eu enviei três cartas a certo homem, mas não recebi resposta. Após refletir muito, cheguei à conclusão de que não havia outro jeito de viver - expressei esse sentimento nas cartas e as enviei, como uma desesperada que se atira de um promontório sobre as ondas revoltas, e, apesar de cansar de esperar, não obtive resposta. Perguntei disfarçadamente a Naoji o que fazia a referida pessoa, e soube que ele continuava o mesmo, encharcava-se de saquê todas as noites, escrevia somente obras cada vez mais imorais e era maldito e odiado pelas pessoas de bem. Além disso, ele havia proposto a Naoji que iniciasse atividades editoriais. Este se entusiasmou com a perspectiva de contar com o apoio dele e de mais dois ou três romancistas como conselheiros, e que já havia pessoas dispostas a empatar capital no negócio. Ao ouvir o que Naoji dizia, tive a impressão de que a atmosfera envolvendo a pessoa amada não se achava nem um pouco impregnada do meu odor e, em vez de um sentimento de vergonha, eu comecei a presumir que esse mundo era um monstro, completamente diferente daquilo que eu imaginava. Sentia-me abandonada num campo, no pôr-do-sol de um dia de outono, onde, por mais que eu berrasse e esperneasse por alguém, não era ouvida - esse pensamento trágico infiltrou-se em meu peito de uma forma jamais vivenciada antes. Seria isso uma desilusão amorosa? Enquanto me deixavam só, em pé, no campo, o sol se punha completamente e, se pensar que não me restava senão morrer congelada sob o orvalho congelante noturno, com a sensação de sufocar a respiração, os ombros e o peito se sacudiam violentamente, as lágrimas nem escorriam, somente o choro lancinante.

Não havia outro jeito, senão eu ir a Tóquio encontrar-me com o senhor Uehara. A minha vela já fora içada e então me lancei ao mar distanciando-me do porto. Não posso ficar parada, agora preciso ir até o fim. Quando iniciei os preparativos em segredo, com objetivo de rumar para Tóquio, o estado de saúde de mamãe agravou-se repentinamente.

Uma noite, após um forte acesso de tosse, ao medir sua temperatura, vi que estava com trinta e nove graus.

- É porque fez frio hoje. Amanhã eu estarei boa. - disse mamãe numa voz fraca e seguida de tosse, que me deu a impressão de não ser normal e eu decidi chamar o médico da vila quando amanhecesse.

$\mathrm{Na}$ manhã seguinte, a febre havia baixado para trinta e sete graus e a tosse também tinha acalmado. Mesmo assim, fui à procura do médico da vila e lhe contei que ultimamente mamãe debilitava a olhos vistos e que a febre havia voltado na noite anterior. A tosse também não era de um resfriado qualquer, então, pedi-Ihe que a examinasse.

Ele respondeu-me: "Está bem, irei mais tarde. Estas frutas eu ganhei de presente". Dizendo isso, ele me deu três peras que tirou da despensa do canto da sala. Pouco depois do meio-dia, ele veio para examinar mamãe, vestido de haori de 
verão ${ }^{46}$ feito de shirogasuri ${ }^{47}$. Como no procedimento anterior, colocou-lhe 0 estetoscópio aqui e ali, deu umas batidas com o dedo, examinou-a demoradamente com cuidado e me informou:

- Não há com o quê se preocupar. Se tomar o remédio, ela ficará boa.

Não sei por quê, eu achei graça, reprimi o riso e disse:

- Não é preciso uma injeção? - ao perguntar-Ihe, ele respondeu seriamente:

- Não há necessidade. É somente um resfriado. Ficando em repouso, logo o sintoma desaparecerá.

Mas a febre de mamãe persistia mesmo após uma semana. A tosse havia cessado, mas a febre oscilava entre trinta e sete graus e sete décimos, pela manhã, e trinta e nove, à tarde. O médico, desde o dia seguinte àquele, estava de repouso, por causa de uma indigestão; eu mesma precisei pedir-Ihe a medicação, informando à enfermeira sobre o estado péssimo de mamãe. Ela se comunicava com ele, que repetia: "É um resfriado comum; não se preocupe" - e receitava remédios líquidos e em pó.

Como sempre, Naoji se encontrava em Tóquio. Ele não retornava para a casa havia uns dez dias. Sozinha e apreensiva, enviei um cartão postal ao tio Wada notificando-o da mudança que se operara na saúde de mamãe.

No décimo dia após a ocorrência da febre, finalmente, o médico da aldeia veio examiná-la, alegando que finalmente se curara dos intestinos.

Ele examinou-a meticulosamente e, com expressão preocupada, disse:

- Já sei o que é, já sei!

$E$, encarando-me:

- Descobri a causa da febre. Há uma infiltração de água no pulmão esquerdo, mas não se preocupe. A febre continuará, mas, ficando em repouso, não há com o que se preocupar.

"Será isso mesmo?" - Pensava eu, e, como quem procura agarrar-se a uma palha quando está naufragando, encontrei, nas palavras do médico, um pouco de alento para a minha angústia.

Depois que ele se foi, eu disse:

- Ainda bem, mamãe. Um pouquinho de infiltração de água todo mundo tem. É só manter o otimismo que a senhora ficará bem. A irregularidade do verão deste ano é que foi culpada. Eu detesto o verão. Nem mesmo das flores de verão eu gosto.

Fechando os olhos, ela sorriu:

- Dizem que os apreciadores do verão morrem no verão. Eu também pensei que morreria próximo ao verão, mas, com o retorno de Naoji, consegui sobreviver até 0 outono.

46 Haori, espécie de capa que veste sobre o quimono, com as mangas dobradas e mais curtas que o kimono.

47 Shirogasuri, tecido branco estampado com motivos de letras nas cores azul marinho ou preto. 
Pensando que até alguém como Naoji servia de alicerce para a existência de mamãe causou-me sofrimento.

- Então, como o verão passou, quer dizer que o pico da crise perigosa também, não acha? Mamãe, as lespedezas do quintal estão floridas. Também as patrínias, as sanguissorbas, as campânulas, as themedas e eulálias. O quintal está totalmente forrado de ares de outono. Quando chegar outubro com certeza a sua febre baixará.

Eu estava rezando para que isso acontecesse. Eu torcia para que esse tempo quente e abafado de setembro passasse logo. Depois, quando começassem a florescer os crisântemos e perdurasse o clima sereno e seco, com belos dias outonais, certamente a febre baixaria, e mamãe se fortaleceria. Eu também poderia encontrar-me com aquela pessoa, e concretizar os meus planos para que houvesse uma floração linda e triunfal como a de um crisântemo. Ah, como seria bom se outubro chegasse logo e baixasse a febre dela!

Após passar uma semana do envio do telegrama a tio Wada, ele nos enviou o velho Dr. Miyake de Tóquio, que trabalhava como médico da corte, trazendo consigo a sua enfermeira.

O velho médico era um conhecido do nosso falecido pai. Ao vê-lo, mamãe mostrou-se extremamente feliz. Desde antigamente, ele era notório pela sua má conduta. Dizia o que queria sem se importar a quem. Além disso, pareceu-me que ele fazia o gosto da mamãe, os dois deixaram o tema de doença por algum tempo e ficaram a conversar descontraidamente. Ao dirigir-me à sala, levando o pudim que havia feito, já o exame tinha sido concluído e o velho médico, com estetoscópio suspenso desajeitadamente ao ombro, estava sentado na cadeira de vime do corredor da sala.

- Eu também gosto de comer $u d o n^{48}$ em pé no yatal ${ }^{49}$. Não é questão de ser ou não saboroso.

Ele continuava a falar, despreocupadamente, de coisas corriqueiras. Mamãe também o ouvia com uma feição serena. Ela não tinha nada - suspirei aliviada.

- E então, Doutor? O médico dessa vila constatou que havia uma infiltração de água no pulmão esquerdo...

Enchendo-me de coragem de repente, perguntei ao velho médico Miyake, e ele respondeu-me com naturalidade e leveza:

- Ah, não se preocupe, não há perigo.

- Que bom! Não é mesmo, mamãe?

Sorri do fundo do meu coração e depois a chamei.

- Ele disse que está tudo bem, sabia?

Nesse momento, o Dr. Miyake levantou-se da cadeira de vime e se encaminhou em direção à sala chinesa. Como deu indício de querer falar comigo em particular, levantei-me e o segui.

\footnotetext{
48 Tipo de macarrão.

49 Barraca de rua onde se serve comida, especialmente udon.
} 
O velho doutor dirigiu-se ao lado do quadro da sala chinesa e parou:

- Sabe, hoje eu ouvi uns estalidos - me disse.

- Não seria infiltração de água?

- Não.

- Bronquite pulmonar? - perguntei-Ihe, já lacrimejante.

- Não.

Tuberculose! Não queria pensar que era isso. Fosse pneumonia, infiltração de água, bronquite pulmonar, haveria de curar com as minhas próprias forças. Mas fosse tuberculose, ai... não teria mais jeito. Senti o chão desmoronar aos meus pés.

- O barulho... o estalido... é realmente muito grave?

Eu já estava em prantos, com o peito sufocado.

- O lado direito e o esquerdo, está tudo tomado. delicioso....".

- Mas mamãe ainda está sadia. Ela saboreia o arroz, dizendo: "delicioso,

- Não tem mais jeito.

- É mentira, não é? Não é nada disso, não é? E se ela comer bastante manteiga, ovos, carnes, ficará boa, não é? E se fortificar o corpo, a febre baixará, não é?

- Certo, o negócio é se alimentar bem, seja o que quer que seja.

- Não é? Não é mesmo? Ela come uns cinco tomates todos os dias.

-É, tomate é bom.

- Então, tudo bem? Ela ficará boa, não é mesmo, Doutor?

- Em todo caso, a doença, desta vez, pode tirar-lhe a vida. É melhor ficar preparada.

Neste mundo, há diversas coisas que independem da força humana - pela primeira vez na vida, tive a impressão da existência dessa parede de desespero.

- Quanto tempo de vida Ihe resta... dois, três anos? - indaguei, tremendo, baixinho ao médico.

-- Eu não tenho como saber. Seja como for, não há o que fazer.

E, assim, nesse mesmo dia, o Dr. Miyake, alegando que havia reservado uma pousada para aquele dia nas termas de Nagaoka de Izu, foi embora com aquela sua enfermeira. Eu os acompanhei até o portão, e, em seguida, retornei ofegante para a cabeceira de mamãe, sentando-me a seu lado. Ela estava sorrindo, como se nada tivesse acontecido, e perguntou-me:

$-\mathrm{O}$ que disse o doutor?

- Que era bom baixar a febre.

- E o meu peito?

- Não é caso muito grave. Olhe, é como fosse a doença da vez passada. Logo que os dias ficarem mais amenos, gradativamente a senhora ficará boa. 
Eu queria acreditar na minha própria mentira. Palavras terríveis como Tirar a vida... resolvi esquecê-las! Tive a sensação de que se mamãe morresse, minha própria vida se esvairia junto com ela. Isso era inconcebível como realidade. A partir daquele momento, eu esqueceria tudo e viveria em função de mamãe, e prepararia iguarias deliciosas: peixes, sopas, conservas, fígado, caldo de carne, tomates, ovos, leites. Seria bom se tivesse tôfu ${ }^{50}$. Faria misoshiru ${ }^{51}$ de tôfu. Arroz branco. Mochi ${ }^{52}$, daria tudo quanto é coisa gostosa a ela, mesmo que tivesse de vender todas as minhas coisas.

Levantei-me e fui à sala chinesa. Depois, carreguei a espreguiçadeira para perto da varanda da sala e sentei-me, de modo a poder ver o rosto de mamãe. Ela estava repousando e não aparentava em nada uma pessoa doente. Os seus olhos estavam belos e límpidos, e seu aspecto facial estava rosado e vívido. Todas as manhãs, ela se levanta impecável, vai ao banheiro, penteia-se na sala de três tatamis, arruma a sua própria roupa, volta ao leito, toma a refeição sentada, ora se deita, ora se levanta, lê jornais e revistas durante toda a manhã, e se torna febril somente à tarde.

- Ah, mamãe está forte, não há dúvidas de que ela está bem.

Como num monólogo, desmenti energicamente do fundo do coração o diagnóstico emitido pelo Dr. Miyake.

Enquanto pensava na chegada de outubro, quando floresciam os crisântemos, comecei a cochilar. Saí à margem de um lago num bosque cuja paisagem eu jamais vira na realidade, mas que me era familiar, porque a tinha visto em sonhos, o que me fez exclamar: "Eis-me outra vez aquil". Estava caminhando silenciosamente ao lado de um jovem trajado em estilo japonês. Tive a impressão de que toda a paisagem estava envolta numa bruma esverdeada. No fundo do lago, uma delicada ponte branca estava submersa.

- Ah, a ponte está submersa. Hoje, não dá para ir a nenhum lugar. Vamos descansar neste hotel. Com certeza, há um quarto vago aqui.

Havia um hotel de pedra à margem do lago. As paredes de pedra do hotel estavam molhadas de névoa. Acima do pórtico de pedra, estava escrito em letras finas e douradas: Hotel Switzerland. Enquanto lia Swi, de repente, eu me lembrei de mamãe. Como estará ela? Será que ela também virá a este hotel? Foi a dúvida que despontou. Depois, junto com o jovem, atravessei o pórtico de pedra e entramos para o jardim da frente. Envolta pela bruma, estava florida no jardim uma flor grande e vermelha, semelhante à hortênsia. Quando eu era criança, sentia uma tristeza estranha ao ver o meu cobertor com as mesmas estampas, mas pensei que essas flores realmente existiam.

- Você não está com frio?

- Sim, um pouco, minhas orelhas estão úmidas de orvalho e estão geladas. Respondi rindo, e perguntei-Ihe:

- O que será que a mamãe vai fazer?

50 Espécie de queijo de soja.

51 Sopa à base de levedo de soja.

52 Bolinho feito de arroz glutinoso moído em pasta e depois moldado. 
Nisso, o jovem sorriu, com pesar e piedosamente:

- Ela já está debaixo do túmulo.

$-\mathrm{Ah}$ !

Soltei um leve grito. Era verdade, mamãe já não existia. Não é que já tínhamos feito o funeral faz muito tempo? Ai, mamãe já faleceu. Quando me conscientizei disso, de repente, fui tomada por um sentimento de solidão que estremeceu todo o meu corpo, e acordei.

A varanda já estava totalmente na penumbra. Estava chovendo. A sensação de solidão esverdeava todo o ambiente, como no sonho.

- Mamãe! - Gritei.

Ela me respondeu com a voz calma: Ihe:

- O que está fazendo?Levantei num impulso, corri alegre para a sala e disse-

-- Sabe, agora há pouco eu estava cochilando. hein?

- Ah, é? Estive pensando no que você estaria sonhando. Que cochilo longo,

Ela riu alegremente.

Só o fato de ela estar viva e respirando delicadamente me deixou muito feliz e, grata, não pude conter as lágrimas.

- E o menu do jantar? A senhora tem alguma preferência? - perguntei-Ihe em tom de brincadeira.

- Não, não tenho. Não quero nada. Minha febre subiu hoje a trinta e nove graus e cinco décimos.

De repente, fui tomada pelo desânimo. Como se estivesse sem rumo, olhei para dentro do quarto na penumbra. Por um instante, fiquei com vontade de morrer.

$-O$ que terá acontecido? Trinta e nove graus e cinco décimos.

- Não é nada. Só não gosto do instante que precede a febre. É que a cabeça começar a doer, me dá calafrios pelo corpo todo e logo vem a febre.

Lá fora já havia escurecido, a chuva havia parado e começara a ventar. No instante em que acendi a luz, enquanto caminhava para a sala de jantar, mamãe me pediu:

- Não ligue a luz, me ofusca os olhos.

- Não é desagradável ficar deitada no escuro? - perguntei-Ihe.

- Como fico deitada de olhos cerrados, não faz diferença. Não me sinto nem um pouco sozinha. Ao contrário, não gosto de sentir a luz ofuscando os olhos. A partir de agora, peço-lhe para deixar a luz da sala desligada, sim?

Para mim, aquilo era um mau presságio. Apaguei a luz, fui ao aposento ao lado, acendi o abajur. Senti-me extremamente triste, corri para a sala de jantar e me servi de salmão em conserva sobre o arroz frio. Não conseguia parar de chorar. 
Ao anoitecer, o vento começou a soprar mais forte e, das nove em diante, transformou-se em tempestade. A cortina de bambu da varanda que eu havia enrolado uns dois ou três dias antes agora fazia barulho constante batendo na janela, e eu estava no quarto ao lado da sala lendo com uma estranha euforia a Introdução à Economia, de Rosa Luxemburgo ${ }^{53}$. Havia trazido esse livro do quarto de Naoji, sem sua permissão juntamente com as Antologias de Lênin $^{54}$, bem como as Revoluções Sociais de Kautsky ${ }^{55}$, e deixado sobre a minha escrivaninha no quarto ao lado. Nisso, de manhã, mamãe na volta do seu asseio matinal, pegou cada livro, deu uma espiada e colocou-os no lugar. Ela respirou fundo, com olhar triste, sem expressar crítica nem desgosto. Os autores de mamãe são Hugo ${ }^{56}$, Dumas pai e filho ${ }^{57}$, Musset ${ }^{58}$, Daudet ${ }^{59}$ e outros. Apesar de esses autores recorrerem a uma narrativa amena, há indícios de revolução no conteúdo. Uma pessoa como ela, dotada de cultura inata - essa palavra soa estranha - enfim, uma pessoa portadora de semelhantes dotes, talvez seja capaz de aceitar a revolução como uma coisa natural. Até mesmo eu, ao ler o livro de Rosa Luxemburgo... não que não me sintisse um tanto pedante, mas tenho os meus interesses em aprender sobre o livro. O assunto é ciência econômica, mas, se o leio como tal é extremamente maçante. $\mathrm{Na}$ verdade, são coisas simples e de conhecimento de todos. Aliás, para mim, talvez seja incompreensível a ciência econômica. De qualquer maneira, não a acho nada interessante. A economia é uma ciência que consiste na premissa de que o ser humano é sovina, eternamente sovina. Para aquele que não é, o problema de dividir e distribuir, bem como qualquer outro aspecto da questão, deixa de ter interesse. Mesmo assim, li esse livro e, em certas passagens, senti uma sensação estranha. É porque a autora desse livro, corajosamente, sem hesitação, vai destruindo todas as velhas ideologias, uma a uma. Veio à minha mente a imagem de uma mulher casada que, mesmo contrariando os preceitos morais, vai correndo para junto do seu amado. Ideologia destrutiva. A destruição é triste e causa compaixão, mas é bela. Destruir, reconstruir e concluir - este é o sonho. Talvez nunca chegue o dia da conclusão, mas, uma vez iniciada a destruição, será preciso levá-la até o fim para a concretização do amor que se procura. É imprescindível fazer uma revolução. Rosa dedica triste e ardente amor ao marxismo.

Aquilo ocorreu no inverno, há doze anos.

53 Rosa Luxemburgo (1871-1919): economista e socióloga alemã.

54 Antologias de Lênin. Vladimir llich Lenin (1870-1924) foi fundador de direitos do trabalhador rural russo. Em novembro de 1917, ele liderou a revolução bolchevique. Revolução e Estado é outra de suas obras.

55 Karl Johann Kautsky (1854-1938), sociólogo e economista alemão que difundia o conceito marxista. Posteriormente, converteu-se para o Partido Social Democrata e se opôs à Revolução Russa, sendo criticado por Lênin.

56 Victor Hugo (1802-1885), dramaturgo, poeta e romancista francês. Suas obras: Nostradamus de Paris e Os miseráveis.

57 A obra mais conhecida de Alexandre Dumas (1803-1870) Conde de Monte Cristo, a de Alexandre Dumas Filho (1824-1895) é Dama das Camélias. Ambos foram dramaturgos e romancistas franceses.

58 Alfred de Musset (1810-1857), poeta, romancista e dramaturgo francês, representante do romantismo; escreveu: Noite.

59 Alphonse Daudet (1840-1897), romancista francês do gênero naturalista. 
- Você é exatamente como garota de Sarashina Nikki ${ }^{60}$ (Diário de Sarashina). Não adianta falar mais nada.

Após dizer essas palavras, minha amiga afastou-se de mim. Eu the devolvera o livro de Lênin sem ler.

- Já leu?

- Me desculpe, não li.

Estávamos sobre a ponte, de onde se via a Torre de Nicolai ${ }^{61}$.

- Por quê? Como não leu?

Essa amiga era uma polegada mais alta que eu e era boa aluna de línguas. $O$ gorro vermelho combinava bem com o formato do seu rosto, era linda e tinha a fama de se parecer com a Gioconda ${ }^{62}$.

- Eu não gostei da cor da capa do livro.

- Você é muito esquisita. Não foi isso, foi? Na verdade, você ficou com medo de mim, não é?

- Eu não tenho medo de você. Somente não suportei a cor da capa.

- Ah, é?

Disse-me com expressão melancólica, e acrescentou que eu era Sarashina Nikki. Ela decidiu que não adiantava falar mais nada para mim.

Nós ficamos por algum tempo caladas, observando o rio invernal.

- Felicidades. Se isso for separação eterna, felicidades eternas. Byron ${ }^{63}$. leve.

Ela recitou rapidamente os versos de Byron, no original, e abraçou-me de

Eu lhe disse envergonhada:

- Me desculpe, viu? - Eu the disse em voz baixa, e fui andando em direção à estação Ochanomizu. Ao virar-me, vi minha amiga sobre a ponte, ainda imóvel, olhando-me fixamente.

Desde então, nunca mais a vi. Nós duas freqüentávamos a casa de um professor estrangeiro, mas estudávamos em escolas diferentes.

Já se passaram doze anos. No entanto, não consegui avançar um passo sequer de Sarashina Nikki. Afinal, que fiz eu durante esse tempo todo? Não tive desejos de fazer nenhuma revolução, nem mesmo sabia da existência do amor. Até hoje, os adultos nos ensinaram que revolução e amor são duas coisas estúpidas e detestáveis. E, mesmo antes, durante a guerra, nós pensávamos que assim fossem. Contudo, após a derrota na guerra, perdemos a confiança nos adultos e começamos a sentir que o caminho da verdadeira vida era o oposto daquilo que nos foi dito. Cheguei à conclusão de que os adultos mentiam descaradamente ao dizer que as

60 Diário de Sarashina, publicado por volta de 1060, de autoria da filha de Takasue Sugawara.

61 Torre da Catedral Ortodoxa Russa de Tóquio.

62 La Gioconda, obra prima conhecida como Mona Lisa, do mestre italiano Leonardo da Vinci (14521519).

${ }^{63}$ Byron, George Gordon (1788-1824), poeta inglês. Escreveu Don Juan. 
uvas ainda estavam verdes. Quero convencer-me de que o homem nasceu para o amor e para a revolução.

A porta corrediça se abriu repentinamente, e mamãe apareceu com um sorriso no rosto e perguntou-me:

- Você ainda está acordada, não está com sono?

Ao olhar o relógio sobre a mesa, percebi que já era meia-noite.

- Não senhora, não estou, nem um pouco. Estava lendo o livro sobre o socialismo e acabei me emocionando.

- Ah, é? Será que não tem alguma bebida? Nesses casos, se tomar um pouco de saquê e se deitar, você conseguirá dormir bem, viu?

Ela me falava num tom zombeteiro, e essa sua atitude tinha um ar de faceirice, beirando a decadência.

Logo chegou o mês de outubro, mas não vimos aquele céu claro e límpido típico de outono. Sucederam-se dias chuvosos, quentes e úmidos. A febre da mamãe oscilava entre trinta e oito e trinta e nove graus todas as tardes. Foi quando, certa manhã, presenciei uma coisa terrível. As mãos da mamãe estavam inchadas. Ela, que dizia ser a refeição matinal a mais saborosa, ultimamente permanecia sentada sobre o leito e se servia de pouquíssima comida, como um caldo leve de arroz, e se recusava a alimentar-se de outros pratos, dizendo que cheiravam forte. Nesse dia, eu lhe ofereci caldo de matsutake ${ }^{64} \mathrm{e}$ até isso ela recusou, alegando não estar com apetite. Colocou a tigela na boca somente uma vez, devolvendo-a em seguida sobre a mesa. Nesse instante, ao olhar para a sua mão, fiquei assustada. A mão direita estava bastante inchada.

- Mamãe! As suas mãos não estão doloridas?

Até o rosto aparentava estar inchado, com um tom esverdeado.

- Não é nada, isso não é nada.

- Desde quando estão assim?

Ela estava com os olhos semicerrados, como se estivessem ofuscados pelos raios de sol, e permaneceu calada. Tive vontade de berrar e chorar. Aquelas mãos não eram de mamãe. Eram de alguma pessoa estranha. As dela são pequenas e delgadas. Eu as conheço bem. Mãos carinhosas. Mãos graciosas. Será que suas mãos se esvaíram para sempre? A mão esquerda ainda não estava tão inchada, mas doía-me muito ver aquilo. Não suportei olhá-las e desviei a atenção para uma cesta de flores que ornava a alcova.

A situação estava insuportável e eu estava a ponto de cair em prantos. Levantei-me e fui à sala de jantar, onde encontrei Naoji se servindo de ovos cozidos de gema mole. Mesmo ele retornando à casa de vez em quando, à noite, invariavelmente, ia à pensão da senhora Osaki se embebedar de shôchû. De manhã, ele estava sempre de péssimo humor, servia-se somente de quatro ou cinco ovos cozidos, subia ao seu quarto, ora se deitando, ora se levantando.

- As mãos de mamãe incharam.

64 Espécie de cogumelo que cresce entre pinheirais. 
Dizendo isso a Naoji, fiquei cabisbaixa. Sem poder prosseguir a conversa, continuei cabisbaixa e acabei chorando. Naoji também permanecia calado. Depois, virei o rosto e disse:

- Já não tem jeito. Você não percebeu? Se as mãos da mamãe incharam tanto, não tem mais jeito. - disse-lhe apoiando-me na beirada da mesa. Naoji também ficou amuado e disse, com um ar sombrio:

- Está próximo o fim dela. Que situação chata!

- Eu quero curá-la mais uma vez. Quero curá-la de qualquer jeito. - quando disse isso, esfregando a mão direita na esquerda, Naoji de repente começou a choramingar e, esfregando os olhos com os punhos, disse:

- Não há nada de bom para nós. Para nós, não há nada de bom.

Naquele dia, Naoji partiu para Tóquio a fim de notificar o estado de saúde de mamãe a tio Wada e receber instruções do que fazer dali em diante. Eu, se não estava com mamãe, permanecia chorando de manhã à noite. Mesmo quando ia buscar o leite, na cerração matinal, ao mirar o espelho para ajeitar os cabelos e ao passar batom, eu estava sempre chorando. Vinham na minha mente, como fosse um quadro, os dias felizes passados com mamãe, e não conseguia parar de chorar, por mais que me esforçasse. À tarde, ao escurecer, ao ir à varanda da sala chinesa, solucei por um longo período. As estrelas brilhavam sob o céu outonal, mas sob os meus pés, apenas um gato de alguma casa enrolado, imóvel.

No dia seguinte, o inchaço das mãos de mamãe havia se agravado. A comida, ela tinha deixado intocada e havia recusado o suco de laranja, alegando alguma irritação na boca, que a impedia de beber.

- Mamãe, e se colocarmos novamente a máscara recomendada por Naoji?

Minha intenção era dizer isso rindo, mas, enquanto eu falava, a tristeza me tomou e acabei elevando a voz e chorando.

- Você está trabalhando demais, deve estar muito cansada. Contrate uma enfermeira. -- Disse-me ela em tom suave. Compreendi que mamãe estava mais preocupada com a minha saúde do que com a dela e me senti ainda mais triste. Levantei-me, corri até o banheiro e chorei desesperadamente.

Logo após o almoço, Naoji trouxe o velho Dr. Miyake, acompanhado de duas enfermeiras.

O velho médico era sempre brincalhão, mas, nesse dia, aparentava irritação. Foi entrando sem cerimônia no quarto da doente, começando logo a examiná-la. E, depois, sem se dirigir a ninguém em especial, falou:

- Ficou fraca, não? - Proferindo somente isso em voz baixa, aplicou-lhe uma injeção de cânfora. delírio.

- Doutor, onde o senhor vai se hospedar? - disse mamãe, como que em

- Ficarei outra vez em Nagaoka. Não se preocupe, porque eu já deixei reservado um quarto. Essa paciente precisa parar de se preocupar com os outros e pensar mais em si, e precisa se alimentar com tudo o que ela gosta. Se comer 
alimentos nutritivos, ela ficará boa. Voltarei novamente amanhã. Deixo aqui a enfermeira.

O velho médico falou em voz alta propositalmente, para que a paciente escutasse. Sinalizou com os olhos para Naoji e levantou-se.

Naoji acompanhou o médico e a enfermeira. Após retornar, seu rosto procurava reprimir o impulso de chorar.

Silenciosamente, saímos do quarto e dirigimo-nos à sala de jantar.

- Já não tem mais jeito, não é?

- Que dureza!

Naoji torceu a boca e riu:

- Parece que o declínio da saúde aconteceu repentinamente. Ele me disse que poderia esperar o pior de hoje para amanhã. - enquanto dizia isso, brotaram lágrimas dos seus olhos.

- Será que não é preciso enviar telegramas para vários lugares? - Falei, em contrapartida, serena e calmamente.

- Sobre os telegramas, consultei titio. Ele me disse que, na situação atual, não será possível reunir tantas pessoas. Mesmo que recebêssemos as visitas, seria desrespeitoso acomodar as pessoas numa casa tão apertada como essa e, não há hospedaria decente nas imediações. Além do mais, nas termas de Nagaoka, não conseguiríamos reservar sequer dois ou três quartos. Em suma, agora somos pobres, não temos condições para chamar pessoas importantes. Titio deverá vir mais tarde, mas aquele sujeito sempre foi um sovina, não serve para nada. Ainda ontem à noite, ignorou a doença da mamãe e me encheu de sermões. Não há provas nos quatro cantos do mundo de alguém que tenha escutado o sermão de um sovina e tenha se regenerado. Os dois são irmãos, mas entre mamãe e ele existe um abismo como entre o céu e terra, o que me deixa chateado.

- Mas... fora eu, a partir de agora, você terá que depender dele...

- Deus me livre! É melhor virar mendigo de vez. A mana, sim, precisará pedir arrimo para o titio.

- Eu... - as lágrimas rolaram. - Eu tenho aonde ir.

- Casamento? Já está decidido?

- Ainda não.

- Independência? Ou mulher batalhadora? Deixe disso!

- Não é também independência. Eu vou virar revolucionária.

-Ah, é?

Naoji olhou-me surpreso com certo espanto.

Nesse instante, a enfermeira que o doutor Miyake trouxera veio me chamar.

- A senhora sua mãe parece que tem algo a dizer-lhe.

Corri para o leito da mamãe e sentei-me na sua cabeceira, aproximei o meu rosto ao seu e perguntei: 
$-\mathrm{O}$ que foi?

Ela gesticulava parecendo querer contar alguma coisa, porém continuava calada, e perguntei-Ihe:

- Água?

Ela meneou a cabeça levemente, no sentido de não estar com sede. Passados alguns minutos, disse-me, com uma voz débil:

- Tive um sonho.

- Ah, é? Que tipo de sonho.

- Sonhei com cobras.

Senti um calafrio.

- Kazuko, vá verificar se não há uma cobra fêmea listrada de vermelho sobre a pedra do degrau da varanda.

Senti um frio na espinha, levantei-me e sai para a varanda. Ao olhar através do vidro da porta, estendida sobre a pedra do degrau, lá estava a cobra. Ela estava banhando-se ao sol de outono. Fui tomada por uma sensação de tontura, como se tudo ao redor girasse.

"Eu a conheço. Você engordou um pouco e envelheceu, comparada àquela cobra que vi uma vez. Você é a mesma cobra fêmea cujos ovos eu queimei, não é? Já senti na pela a sua vingança, portanto, vá-se embora, peço-lhe que se vá, depressa!"

Do fundo do meu coração, eu desejava que a cobra sumisse dali. Fiquei à espera contemplando-a, mas ela não fazia menção de se mover. Não sei por que, mas não queria que a enfermeira avistasse aquela cobra. Para espantá-la, bati o pé com força sobre o assoalho.

- Mamãe, não tem nenhuma cobra lá. A senhora não deve levar a sério os seus sonhos. - Assim dizendo, elevei propositalmente a voz. Ao lançar o olhar em direção à pedra do degrau, vi que a cobra finalmente havia começado a se mover, deslizando sobre a pedra preguiçosamente.

Já não adianta, não adianta. Após ver aquela cobra, pela primeira vez a resignação tomou conta do meu coração. No momento do falecimento de papai, dizem que havia uma cobrinha preta na cabeceira dele, e, vi naquela mesma ocasião, cobras pendendo de todas as árvores do quintal.

Parecia que o ânimo de mamãe tinha-se esvaído. Até para se sentar no leito era-Ihe difícil e ela vivia em constante estado de sonolência. Havia se entregado totalmente aos cuidados da enfermeira. Por sua condição, passava a impressão de que não conseguia mais digerir os alimentos. Desde que havia visto a cobra, poderse-ia dizer que experimentei a sensação de ter ultrapassado toda a tristeza e alcançado uma paz de espírito semelhante a um alívio no coração; e pensei em permanecer ao lado da mamãe o máximo de tempo possível.

Assim, nos dias subseqüentes, sentei-me à sua cabeceira e ocupei o tempo tricotando. Eu era mais ágil em tricotar e costurar que outras pessoas, porém fazia tudo malfeito. Por isso, mamãe sempre apontava os meus erros e me ensinava detalhadamente o modo correto de costurar e tricotar. Nesse dia, não estava com 
vontade alguma de tricotar, mas como estava junto à sua cabeceira, para não denotar a gravidade da situação, e também para agradá-la, comecei a remexer na caixa de lã. Comecei a tricotar como se estivesse alheia aos acontecimentos, a fim de dar uma aparência de normalidade.

Mamãe fixou o olhar em minhas mãos e disse:

- Você vai fazer as suas meias, não? Nesse caso, terá de aumentar oito pontos senão ficarão apertadas.

Quando criança, por mais que mamãe insistisse em me ensinar, eu não conseguia tricotar bem; e, como sempre, acabei me atrapalhando e fiquei envergonhada, com saudades da infância; pensar que, provavelmente, esta seria a última vez que ela estaria a me ensinar! De repente, desmanchei-me em lágrimas, a ponto de não poder enxergar os fios trançados do tricô.

Deitada como estava, mamãe não parecia absolutamente estar sofrendo. Desde manhã, os alimentos não the apeteciam e eu me limitava a molhar a gaze embebida em chá, levando-a à sua boca, mas ela estava lúcida e, de vez em quando, dirigia-me a palavra serenamente.

- Kazuko, parece-me que saiu no jornal a foto de Sua Alteza Imperial, mostre-me mais uma vez.

Estendi sobre o seu rosto a parte onde estava a foto de Sua Alteza.

- Como ele envelheceu!

- Não é isso, a fotografia é que está ruim. Na foto tirada outro dia, ele aparentava ser mais jovem, parecia divertir-se. Como ele não se alegraria numa época como esta?

- Por quê?

- Pois desta vez Sua Alteza também recebeu a liberdade.

Mamãe sorriu melancolicamente. Depois de alguns instantes, disse:

- Mesmo que eu quisesse chorar, as lágrimas já secaram, sabe?

"Não estaria ele feliz agora?", pensei repentinamente. Esse sentimento de felicidade não seria como um pó dourado com fosco brilho no fundo de um rio de tristezas? Transportar o limite da tristeza, e alcançar a estranha sensação de ser uma tênue luz, se isso se chama felicidade, então Sua Alteza, mamãe e certamente eu somos felizes agora. Manhã calma de outono. Jardim de outono, onde batem suaves raios solares. Deixei de lado o tricô e contemplei o brilho do mar que alcançava a altura do meu peito. eu.

- Mamãe, até hoje eu desconhecia muitas coisas a respeito da vida. - Disse

Havia mais coisas que eu gostaria de Ihe ter dito, mas, envergonhada pela presença da enfermeira, que estava no canto preparando a injeção sedativa, acabei desistindo.

- Você disse, até agora...

Mamãe sorriu ligeiramente ao escutar minhas palavras, e concluiu:

- Ah, então agora você já sabe o que é a vida? 
Não sei por quê, enrubesci.

- O mundo é incompreensível! - mamãe virou o rosto, como num monólogo e murmurou baixinho:

- Para mim é incompreensível. Talvez não haja ninguém que o compreenda, não é? Por mais que passe o tempo, somos todos como crianças. Não compreendemos coisa nenhuma.

$\mathrm{Eu}$, entretanto, tenho de prosseguir vivendo. Talvez eu não passe de uma criança, mas não posso mais esperar ser mimada. A partir de agora, tenho de lutar contra a sociedade. Mamãe deve ser a última das damas a encerrar a sua vida tão bela e tristemente, sem lutar com ninguém, nem odiar, nem trair ninguém. Será que daqui para a frente não haverá lugar nesse mundo, para tais pessoas? As pessoas que falecem tornam-se belas. Sinto que o fato de viver e permanecer vivo é uma coisa horrível; além de nojenta, cheira a sangue. Tentei desenhar na minha imaginação a figura de uma cobra prenhe cavando um buraco no chão. Entretanto, para mim, existe algo com que não posso me resignar. Pode ser até sórdido de minha parte, mas tenho de continuar vivendo, e até que eu concretize o meu ideal, necessito lutar contra a sociedade. Ao saber que o fim da mamãe estava próximo, gradualmente o meu romantismo e a minha melancolia foram se esvaindo, e fui tomada pela sensação de que eu ia me transformando em alguma criatura desonesta e calculista em que não se podia confiar.

Após o almoço desse dia, enquanto eu estava ao lado de mamãe umedecendo sua boca, um carro parou em frente ao portão. Eram os tios Wada que tinham vindo de Tóquio, de carro. Quando titio entrou no quarto e se sentou calado à cabeceira de mamãe, ela escondeu metade do seu rosto com um lenço e, olhando fixamente para ele, chorou. Contudo, só a feição estava chorosa, pois não the vieram lágrimas aos seus olhos. Ela parecia uma boneca. Após alguns minutos, mamãe se voltou para mim e perguntou:

- Onde está Naoji?

Fui ao andar superior, onde Naoji estava deitado no sofá da sala ocidental, lendo uma revista, e disse-lhe:

- Mamãe está chamando. Ele exclamou:

- Ah não, lá vem o muro das lamentações! Como você pode suportar permanecer firme ali? Você tem nervos de aço, não? Ou você é insensível? Eu sofro tanto que até o coração ferve, mas o corpo fraqueja, e não tenho forças suficientes para ficar ao lado de mamãe! - Assim dizendo, Naoji vestiu o casaco e me acompanhou ao andar inferior.

Quando nós nos sentamos junto à cabeceira, mamãe retirou a sua mão de baixo do cobertor repentinamente apontou calada para Naoji e, depois, para mim. Voltou-se em direção a titio e depois juntou as palmas das suas mãos.

- Ah, já sei. Já compreendi. Já compreendi, viu? - disse titio.

Mamãe, como se estivesse aliviada, fechou levemente os seus olhos, e retornou delicadamente as suas mãos para baixo do cobertor.

Chorei e Naoji também soluçou, cabisbaixo. 
Nisso, apareceu o velho doutor Miyake, vindo de Nagaoka, e, mais que depressa, aplicou-lhe uma injeção. Tendo encontrado titio, mamãe teria sentido que já não havia nada com que se afligir, então pediu ao médico:

- Doutor, por favor, me alivie da dor logo. lágrimas.

$\mathrm{O}$ velho médico e titio se entreolharam em silêncio. Nos seus olhos, brilharam

Eu me levantei e dirigi-me à sala de jantar a fim de preparar o kitsune Udon ${ }^{65}$ de que titio tanto gostava. Levei a iguaria para a sala chinesa para ser servida para quatro pessoas: o Doutor, Naoji, titio e titia; e depois mostrei a mamãe os sanduíches do Hotel Marunouchi que titio havia trazido, e quando eu os coloquei ao lado de sua cabeceira, ela me disse em voz baixa:

- Devo estar dando muito trabalho para você, não é mesmo?

$\mathrm{Na}$ sala chinesa, todos conversavam assuntos variados, e titio e titia, alegando terem compromisso inadiável em Tóquio, me entregaram um envelope contendo dinheiro. O doutor Miyake também resolveu se retirar com a enfermeira, junto com titio. Tendo em vista que a consciência da mamãe se mantinha inalterável e o coração ainda não tinha enfraquecido, ele prescreveu diversos medicamentos para a outra enfermeira assistente. O médico concluiu que poderia manter o quadro de saúde dela por meio de injeções e que poderia manter a estabilidade de sua saúde por mais quatro ou cinco dias. Sendo assim, todos partiram para Tóquio, de carro, nesse mesmo dia.

Após despedir-me de todos, ao retornar à sala, mamãe virou-se para mim com um sorriso terno que só mostrava a mim.

- Hoje foi muito trabalhoso para você, não? - Ela me disse em voz baixa, quase sussurrando. Seu rosto estava vívido, e os olhos brilhantes. Essa aparência poderia ser o resultado da satisfação do reencontro com o titio, pensei comigo mesma.

- Não foi, não, senhora.

Também me senti aliviada e Ihe dei um sorriso franco.

$\mathrm{E}$, assim, aquela foi a última conversa que mantive com mamãe.

Depois, passadas umas três horas, ela faleceu. Esse fato ocorreu num entardecer tranqüilo de outono, com a enfermeira a medir-lhe as pulsações, na presença de duas únicas pessoas consangüíneas: eu e Naoji. Nossa bela mãe, que fora a última dos nobres do Japão, havia falecido.

Sua feição estava quase inalterada. Ao contrário da feição de papai, que havia mudado repentinamente, a aparência dela não havia se alterado nada, somente a respiração havia cessado. A ausência de sua respiração era quase imperceptível. O inchaço do seu rosto havia desaparecido desde o dia anterior, suas faces estavam lisas como cera, e os seus lábios finos, ligeiramente retorcidos,

65 Kitsune udon, é tipo de macarrão servido com caldo, que contém pedaços de tôfu fritos. 
pareciam externar um tênue sorriso; mamãe aparentava estar mais encantadora do que em vida. Achei que ela se assemelhava à Maria da Pietá ${ }^{66}$.

${ }^{66}$ Maria da Pietà, de Michelangelo. É a imagem da Virgem Maria lamentando o Cristo morto em seu colo. 


\section{Capítulo VI}

Início da batalha!

Eu não podia ficar mergulhada eternamente na tristeza. Dentro de mim, tinha algo a obter a todo custo através da luta. Nova ética. Não, dizer isso é hipocrisia. Amor. Só isso. Do mesmo modo que Rosa Luxemburgo não podia viver sem se apoiar na nova Ciência Econômica, agora eu não conseguirei viver sem me apoiar no amor. Não me pareceram totalmente estranhas as palavras de ensinamentos que Jesus proferiu antes de enviar os seus doze apóstolos ${ }^{67}$ aos quatro cantos do mundo, a fim de desmascarar a hipocrisia dos religiosos, moralistas, sábios e poderosos da Terra, e de revelar aos homens, sem qualquer hesitação, o verdadeiro amor de Deus.

$\mathcal{N} a ̃ o$ possuais ouro, nem prata, nem cobre, em vossos cintos. Nem alforjes para o caminho, nem duas túnicas, nem alparcas, nem 6ordão. Eis que vos envio como ovelhas ao meio de lo6os; portanto, sede prudentes como as serpentes e símplices como as pombas. Acautelai-vos, porém, dos homens; porque eles vos entregarão aos sinédrios, e vos acoitarão nas suas sinagogas. $\mathcal{E}$ sereis até conduzidos à presença dos governadores, e dos reis, por causa de mim, para thes servir de testemunho a eles e aos gentios. Mas, quando vos entregarem, não vos dê cuidado como, ou o que haveis de falar, porque naquela mesma hora vos será ministrado o que haveis de dizer. Porque não sois vós quem falará, mas o Espírito de vosso Pai é que fala em vós. $\mathcal{E}$ odiados de todos sereis por causa do meu nome; mas aquele que perseverar até o fim será salvo. Quando, pois, vos perseguirem nesta cidade, fugi para outra; porque em verdade vos digo que não acabeis de percorrer as cidades de Israel sem que venha of filho do Homem.

E não temais os que matam o corpo e não podem matar a alma; temei antes aquele que pode fazer perecer no inferno a alma e o corpo. Não cuideis que vim trazer a paz à terra; não vim trazer paz, mas espada. Porque eu vim pôr em dissensão o homem contra seu pai, e a filha contra sua mãe, e a nora contra sua sogra. $\mathcal{E}$ assim os inimigos do homem serão os seus familiares. Quem ama o pai ou a mãe mais do que a mim não é digno de mim; e quem ama o filho ou a filha mais do que a mim não é digno de mim. E quem não toma a sua cruz, não é digno de mim. Quem achar a sua vida, perdê-la-á; e quem perder a sua vida, por amor de mim, achá-[a-á. ${ }^{[68]}$

Início da batalha!

Se eu colocasse o amor acima de tudo e prometesse cumprir todos os mandamentos de Jesus, ele me censuraria? Eu não compreendo porque a paixão pelo sexo oposto é ruim e o amor ao próximo é bom. Em minha opinião, as duas coisas são as mesmas. Existem pessoas que, em prol da paixão e do amor,

67 Jesus Cristo escolheu doze apóstolos a fim de divulgar o evangelho: Pedro, André, João, Tiago o maior, Tiago o menor, Mateus, Felipe, Tomé, Judas, Tadeu, Bartolomeu e Simão.

68 Extraído do Evangelho, Novo Testamento, segundo Mateus, capítulo X. Tradução da edição ecumênica espanhola Editorial Herder S.A., Provenza 388, Barcelona (Espanha) 1968. Edições Loyola - São Paulo - 1978. 
conseguem destruir o corpo e alma no inferno - ai, quero afirmar que essa pessoa sou eu!

Com a ajuda dos meus tios, foi realizado o sepultamento da mamãe em Izu, e a cerimônia foi feita em Tóquio; depois disso eu e Naoji continuamos a viver na mansão de Izu. Apesar de estarmos sob o mesmo teto, vivíamos como estranhos, sem nos comunicar, levando uma existência insuportável. Com pretexto de necessitar de capital para o início de atividades editoriais, Naoji, carregou todas as jóias da mamãe; mas, ao se cansar de embebedar-se em Tóquio, retornava cambaleante para casa, com rosto pálido, semelhante a um doente gravemente enfermo, e dormia na casa de campo de Izu. Certa vez, ele veio acompanhado de uma jovem que parecia ser dançarina. Quando me viu, mesmo ele pareceu um pouco embaraçado, e perguntei-lhe:

- Posso ir a Tóquio hoje? Gostaria de ir passear na casa de uma amiga que não vejo há muito tempo. Ficarei por lá umas duas ou três noites, tome conta da casa, sim? Peça à jovem que cozinhe.

Aproveitei-me do ponto fraco de Naoji, sem lhe dar chances para réplicas, "prudente como uma serpente", depois coloquei cosméticos e pão na bolsa, e, com a maior naturalidade, embarquei para Tóquio a fim de me encontrar com "ele".

Ao desembarcar pelo lado norte da estação de Ogikubo, da linha oficial, no subúrbio de Tóquio, demorava somente vinte minutos, aproximadamente, até chegar à nova residência do pós-guerra do senhor Uehara - isso eu havia ouvido de Naoji.

Nesse dia, soprava um vento forte. Quando desci na estação de Ogikubo, já estava escurecendo. Abordei os transeuntes da rua a fim de pedir informações a respeito do número da casa de Uehara, ouvia deles a direção a seguir, e, assim perambulei durante uma hora pelas ruelas escuras do subúrbio da capital. Senti-me desamparada e as lágrimas começaram a jorrar. Nesse instante, ao tropeçar numa pedra da calçada de pedregulhos, uma das alças do meu tamanco rompeu-se. Fiquei imóvel, sem saber o que fazer. De repente, na penumbra da rua, ao olhar de relance a tabuleta de uma das casas geminadas da direita, tive a impressão de ler "Uehara". Descalça de um dos pés, calçando somente tabi, corri para a frente da casa e, ao certificar-me melhor sobre a tabuleta, vi que estava escrito claramente "Jirô Uehara". O interior da referida casa estava bem escuro.

Que fazer? Hesitei por instantes; depois, com firme propósito, encostei-me à porta gradeada da frente e disse, num sussurro, passando as mãos pelas grades:

- Com licença? O senhor Uehara está?

Obtive a resposta, mas era uma voz feminina.

A porta da frente abriu-se, e uma mulher aparentando três ou quatro anos mais velha que eu, de rosto afinado e aparência conservadora, sorriu na penumbra que cobria a varanda da entrada.

- A senhora é...?

No tom de sua pergunta não havia nenhuma maldade nem precaução.

- Não, sabe, é que...?

Mas, não consegui dizer-lhe meu nome. Para essa pessoa, meu amor pareceu-me suspeita e esquisita. Com certo receio, indaguei: 
- O senhor Uehara não está?

- Não - respondeu a dona, encarando-me com pesar. - mas ele deve estar onde quase sempre está...

-É longe daqui? boca.

- Não, senhora. -- disse, parecendo achar graça, e levando uma das mãos à

- Ele está em Ogikubo, em frente à estação. Se for à casa de oden ${ }^{69}$ chamada Shiraishi, com certeza dirão o paradeiro dele.

Com o coração em sobressalto, eu the disse:

- Ah, sim?

- Moça, olhe o seu calçado...

Convidada pela dona da casa, entrei e me sentei no estrado; ela me deu um pedaço de cordão que deveria ter de reserva. Consertei com ele a alça do tamanco. Enquanto isso, a dona trouxe uma vela acesa para a varanda.

- Me desculpe, mas é que as duas lâmpadas queimaram. Como você pode observar, as lâmpadas de hoje, além de serem extremamente caras, queimam facilmente, não é mesmo? Se meu marido estivesse aqui, poderia comprá-las, porém, ele não retornou para casa nem ontem, nem anteontem à noite. Por isso, hoje faz três noites que dormimos cedo, e, além de tudo, estamos sem um centavo.

A senhora falava com um sorriso sincero e despreocupado. Atrás dela, encontrava-se em pé uma menina magrinha de olhos grandes, de seus doze ou treze anos, que dava a impressão de querer manter distância de desconhecidos.

Inimigas. Eu não penso assim, mas, com certeza, essa senhora e sua filha um dia me odiarão e me terão como inimigas. Pensando nisso, senti como se o meu amor tivesse despertado. Arrumei a alça do tamanco, levantei-me batendo as duas palmas das mãos como se estivesse tirando a sujeira do corpo. Depois, fui dominada por uma sensação de melancolia; pensei em subir correndo para a penumbra da sala, ali eu choraria agarrada às mãos da senhora, mas, ao imaginar minha lastimável e patética figura, perdida sem saber o que fazer, desisti e disse-lhe apenas:

- Muito obrigada.

Fiz-lhe um cumprimento exageradamente formal, saí e, sob forte ventania, fui à luta. Eu o amo, eu o desejo. Eu realmente o amo, sim, eu o quero. Eu o adoro tanto. Não tem jeito, sinto o amor; não posso fazer nada. Aquela senhora é, sem dúvida, boa pessoa, não existe outra igual. Aquela menina também é linda. Mas, ainda que me colocassem no banco dos réus, no julgamento de Deus, não me consideraria nem um pouco má. $\mathrm{O}$ homem nasceu para o amor e para a revolução. Não é possível que Deus me castigue - eu não sou má, absolutamente. Gosto de

${ }^{69}$ Oden é um prato típico de inverno constituído de vários ingredientes como ovos, nabo, rabanete, kombu (alga marinha desidratada), cozidos no caldo de tempero de peixe (dashi). Os ingredientes variam conforme a região. 
verdade, por isso gosto de demonstrar o meu afeto. E até que eu veja ao menos uma vez aquela pessoa, dormirei ao relento, duas ou três noites, hei de...

Encontrei rapidamente a casa de oden chamada Shiraishi, na frente da estação. Mas Uehara não estava ali.

- Está em Asagaya, com certeza. Vá direto pela entrada norte da estação e... bem, seria uma quadra e meia, aproximadamente. No final dessa rua, há uma casa de artigos de metal. Depois dobre à direita, dá uns cinqüenta metros. Chegando lá, há um pequeno restaurante chamado Yanagiya. Ultimamente, o senhor Uehara vive de amores pela dona do Yanagiya, a Osute. Ele praticamente vive lá, puxa vida!

Fui à estação, comprei um bilhete, embarquei no trem da linha oficial para Tóquio e desembarquei em Asagaya pela entrada norte, cerca de uma quadra e meia da casa de artigos de metal, e dobrei a direita, andei meia quadra, chegando a Yanagiya. O local se encontrava em total silêncio. Apareceu a proprietária e me disse:

- Eles saíram agora mesmo, era um grupo grande, e diziam que iriam até Dona Chidori de Nishiogi, e que virariam a noite bebendo.

Ela era mais nova que eu; era calma, fina e atenciosa. Seria esta a tal de Osute, que está de amores com ele?

- Chidori? Em que lugar de Nishiogi?

Senti um aperto no coração e quase chorei. Pensei por um momento se eu não estaria louca.

- Não sei direito, mas, se você descer na Estação de Nishiogi, caminhar para a entrada sul e virar à esquerda... em caso de dúvida, pergunte no posto policial, talvez lhe informe, não? Bem, de qualquer modo, ele não se contenta em embebedar-se em uma só casa, pode ser que entre em algum outro bar antes de chegar a Chidori.

- Bem, vou tentar ir até Chidori. Até logo!

Novamente tomei o trem, de volta a Asagaya. Em Asagaya, embarquei no trem para Tachikawa, na linha oficial, Ogikubo, Nishi Ogikubo, desci na entrada sul da estação. Comecei a perambular pela rua, impelida pelo forte vento. Ao avistar um posto policial, indaguei ao oficial em que direção ficava Chidori. Seguindo a informação do oficial, caminhei a passos largos, praticamente correndo pelas ruas escuras, até finalmente encontrar uma lanterna verde pendente do Chidori. Abri a porta, sem vacilar.

Havia uma pequena entrada e, logo depois, um quarto de aproximadamente seis tatames, cujo ambiente estava esfumaçado pelo cigarro. Ao redor da mesa estavam sentados cerca de dez homens que gritavam ruidosamente: Wah! Wah! Todos eles estavam tomando saquê. Com eles, havia também três moças com aparência mais jovem que eu, fumando e bebendo saquê.

Eu estava de pé na entrada e, de repente, avistei Uehara. Logo que o vi, senti-me como num sonho. Não era possível, ele estava tão diferente... Seis anos! Ele se transformara numa pessoa completamente diferente.

Era este, então, o meu arco-íris, o M. C., a razão da minha existência? Seis anos! Os cabelos soltos e desgrenhados do senhor Uehara continuavam os mesmos 
de antigamente, mas já estavam ralos e desbotados na tonalidade ruiva; o rosto amarelado e inchado, ao redor dos olhos havia irritações avermelhadas e ele estava banguela. Movia e removia a boca continuamente, como se mascasse algo; parecia um velho macaco sentado no canto, com as costas arqueadas.

Uma das moças me avistou e sinalizou com olhos para o senhor Uehara, avisando-o da minha presença. Ele permaneceu sentado, levantou o seu pescoço comprido e magro, olhou em minha direção e, sem alterar sua feição, fez sinal com o seu queixo para que eu subisse. O grupo, sem se importar com a minha presença, continuou com seu ruído estrondoso. Ao me notarem, eles se espremeram a fim de arranjar um lugar para mim no lado direito do senhor Uehara.

Eu me sentei calada ao seu lado. Ele encheu o meu copo de saquê a ponto de transbordar, e depois complementou o seu próprio copo, dizendo em voz rouca e baixa:

- Saúde!

Os dois copos bateram levemente no outro, provocando um triste estalido.

"Guilhotina, guilhotina, zuuuup" - disse alguém, e outro replicou: "guilhotina, guilhotina, zuuuup!" batendo fortemente os copos. Eles bebiam numa só tragada. "Guilhotina, guilhotina, zuuuup!"

Aqui e ali, replicavam as vozes dessa canção, cantadas aleatoriamente, brindando e saudando animadamente, provocando ruídos com os copos. Tinha-se a impressão de que eles despejavam à força o saquê pela garganta abaixo, ao compasso daquele ritmo desenfreado.

- Bem, até logo.

Enquanto um dos clientes, assim dizendo, saía cambaleante, um novo cliente chegava repentinamente e juntava-se ao grupo fazendo apenas um cumprimento discreto para o senhor Uehara.

- Senhor Uehara, aquele trecho... senhor Uehara, sabe aquele trecho... que diz "Aaa." De que maneira devo dizer aquilo? Digo "A, a, a?", ou "aa, a?" Perguntava-lhe, atirando-se para frente, 0 ator Fujita, do Novo Teatro, que reconheci, por tê-lo já visto no palco.

- É "aa, a." "Aa, a", como se dissesse que o saquê de Chidori não é barato. - Retrucou senhor Uehara.

- Ele só fala em dinheiro - disse uma mocinha. cavalheiro.

- Um vintém por dois pardais. Isso é caro? Barato? - Disse um jovem

- Existe esta expressão: "hei de pagar até o ultimo centavo."70 Existe também este provérbio complicado: "Para um homem, cinco talentos; para outro, dois talentos; para outro ainda, um talento" ${ }^{\prime 1}$. Cristo é meticuloso nas contas. - Disse outro cavalheiro.

70 Novo Testamento. Evangelho segundo Mateus, capítulo 5, versículo 26.

Novo Testamento. Evangelho segundo Mateus, capítulo 25, versículo 15. 
- Além disso - disse um outro - ele era um beberrão. É engraçado que há diversas parábolas sobre bebidas na passagem da Bíblia. E, como se esperava, a Bíblia faz críticas "àquele que aprecia o vinho". Diz: "aquele que aprecia o vinho" e não "aquele que bebe vinho". Pelo visto, deveria ter sido um grande beberrão. Eu apostaria que ele beberia uns dois litros de uma vez.

- Já chega, chega. "Aa, a", vocês, que são temerosos da moral, estão tentando usar o nome de Jesus como uma desculpa. Chie, querida, vamos beber. "Guilhotina, guilhotina, zuuuuup!"

Dizendo isso, o senhor Uehara brindou com força o seu copo no da mocinha mais nova e bonita do local, bebendo em seguida um trago. O saquê escorreu pelo canto da sua boca, molhando-lhe o queixo; ele enxugou-o com a palma da sua mão, desesperadamente, com gestos selvagens, depois espirrou com força, seguidamente, cinco ou seis vezes.

Eu me levantei silenciosamente, fui ao quarto vizinho, perguntei o local do lavatório à dona, uma mulher magra, pálida, com aparência doentia; e, ao retornar de volta ao quarto, deparei-me com Chie, aquela mocinha mais jovem e bonita. Ela estava de pé, como se estivesse à minha espera. E, solícita:

- Você não está com fome? - perguntou-me com sorriso amigável.

- Sim, mas trouxe alguns pães comigo...

- Não temos muito a the oferecer por aqui; em todo caso... - disse-me a dona com aparência doentia, sentada preguiçosamente de lado, apoiando-se com certa fraqueza no braseiro.

- Por favor, sirva-se neste quarto. Se você ficar na companhia daqueles bêbados, não conseguirá comer nada durante a noite inteira. Sente-se aqui, também, Chie.

- Ei, Kinu, estamos sem saquê! - berrava o cavalheiro da sala ao lado.

- Já vai, já vai! - respondeu a empregada Kinu, de aproximados trinta anos de idade, vestida com um elegante quimono listrado, trazendo da copa umas dez garrafas de saquê sobre uma bandeja.

- Espere! - a dona chamou a Kinu e disse-Ihe rindo:

- Deixe aqui duas garrafas.

- E depois, Kinu, eu Ihe peço que vá até o Suzuya dos fundos e me traga, com urgência, duas tigelas de udon. mãos.

Eu e Chie estávamos sentadas lado a lado junto ao braseiro, aquecendo as

- Aconchegue-se e cubra-se com o cobertor. Esfriou, não? Não quer beber um pouco?

A dona colocou o saquê da garrafa em sua xícara de chá, e em duas outras.

$\mathrm{E}$, assim, nós três bebemos em silêncio. melancólico.

- Vocês agüentam bem o saquê, não? - A dona disse isso num tom 
Ouviu-se um ruído da abertura da porta da frente, juntamente à voz de um jovem.

- Senhor Uehara, eu trouxe o seu pedido, aqui está. A verdade é que o nosso presidente é mão-fechada. Eu insisti dizendo que eram vinte mil ienes, mas com esforço, só consegui dez mil.

- Está em cheque? - Soou a voz rouca do senhor Uehara.

- Não senhor, dinheiro vivo. Desculpe-me.

- Tudo bem. Darei o recibo.

"Guilhotina, guilhotina, zuuuuup!" - o grupo continuou a fazer ruídos, cantando a canção e brindando com os copos. calafrio.

- Como está Nao? - a dona perguntou a Chie, com a feição séria. Senti um

- Por que devo saber dele? Não sou vigia de Nao.

Chie respondeu meio confusa, com rosto ruborizado.

- Ultimamente, ele não teria tido um desentendimento com o senhor Uehara? Eles estavam sempre juntos - disse a dona com calma.

- Me disseram que ele acabou gostando mais da dança. Provavelmente, arrumou uma namorada dançarina.

- Puxa, esse senhor Nao, além da bebida, se envolve com as mulheres, ele não tem jeito mesmo.

- Tendo o senhor Uehara como professor...

- Mas, o senhor Nao é pior que ele. Um filhinho-de-papai, um devasso...

- Me desculpe. - eu lhes disse, interrompendo com leve sorriso. Pensei que seria mais desrespeitoso se ficasse calada do que se falasse com elas.

- Eu sou irmã de Naoji.

A dona pareceu surpresa. Encarou-me, examinando o meu rosto. Chie mostrou-se calma e disse:

- O rosto é bem parecido com o dele. Ao vê-la em pé, na penumbra da entrada eu me assustei, pensando que fosse o senhor Nao.

- Ah, é?

A dona disse em tom de respeito:

- Deve ser difícil para você vir num lugar tão horrível... E então? Você conhece o senhor Uehara há muito tempo?

- Sim, eu me encontrei com ele faz seis anos e...

Hesitei em dizer, cabisbaixa, quase caí em prantos.

- Desculpem-me a demora. - era a empregada trazendo a tigela de udon

- Sirva-se enquanto está quente. - disse a senhora. 
Debrucei o rosto sobre o vapor que subia do udon e comecei a sugá-lo para dentro da boca. Senti como se estivesse vivenciando a extrema desolação causada pelo fato de estar viva.

"Guilhotina, guilhotina, zuuuuup! Guilhotina, guilhotina, zuuuuup!" - o senhor Uehara veio entrando no nosso quarto, murmurando baixinho a canção, sentou-se ao meu lado com as pernas cruzadas, como se tivesse jogado o corpo, sem dizer uma palavra, e depois entregou um envelope grande para a senhora.

- Não pense em enganar-me somente com isto, não se esqueça do restante, hein? - disse a dona sorrindo, colocando o envelope dentro da gaveta do braseiro, sem se certificar do conteúdo.

- Eu trarei mais. Pagarei o restante no próximo ano.

- Posso acreditar nisso?

Dez mil ienes. Tendo tudo isso, quantas lâmpadas poderiam ser compradas? Mesmo eu, com todo aquele dinheiro, poderia viver um ano sossegada.

Ah! Há algo errado com essas pessoas. Mas, talvez, justamente como o caso do meu amor, eles não consigam continuar vivendo, exceto da maneira como o faziam. Se for verdadeira a premissa de que o homem, uma vez nascido nesse mundo, precisa viver de alguma maneira a sua própria vida, é possível que também a figura dessas pessoas no seu esforço de viver não mereça ódio, afinal. Estar viva. O fato de estar viva. Ah, que empreendimento gigantesco, insuportável e sufocante é viver!

- De qualquer maneira - disse o cavalheiro da sala ao lado, se quiser viver em Tóquio, a partir de hoje, é necessário que o sujeito seja capaz de dizer "Boa tarde" de forma informal e natural. Atualmente, exigir das pessoas virtudes como respeito ou sinceridade é como puxar os pés de um enforcado. Respeito? Sinceridade? Bah! Com isso não é possível continuar vivendo! Se, por acaso, não somos capazes de dizer "Boa tarde!" informalmente não nos resta senão três caminhos: primeiro, retornar à lavoura; segundo, suicidar-se; ou ser sustentado por uma mulher.

- Para um pobre diabo que não consiga fazer nada disso, há pelo menos uma alternativa - disse outro cavalheiro -, que seria depender de Jirô Uehara e beber até cair.

"Guilhotina, guilhotina, vuuuup. Guilhotina, guilhotina, vuuuup."

- Você não tem onde dormir, não é? - disse o senhor Uehara em voz baixa, como num monólogo.

- Eu?

Percebi em mim a cobra preparada para o bote. Maligna! Com um sentimento semelhante, enrijeci o corpo.

- Você consegue dormir no chão amontoado no mesmo quarto com outras pessoas? Sentirá frio, sabe? - murmurou ele, indiferente à minha ira.

- Isso é impossível, ah, tenha dó, coitadinha dela - interpelou a senhora.

- Bah! - exclamou o senhor Uehara, mostrando contrariedade, e emendou: 
- Então, quem lhe mandou vir a um lugar como este?

Permaneci em silêncio. Com certeza, ele lera as minhas cartas; e ele me amava mais que às outras. Percebi instantaneamente pelo tom de suas palavras.

- Não tem jeito. E se pedisse um pernoite para o senhor Fukui? Chie, poderia levá-la? Não, o caminho seria perigoso para duas mulheres desacompanhadas. Quanto aborrecimento! Patroa, eu the peço que leve para a cozinha os calçados desta senhora, em surdina. Eu mesmo a levarei.

Lá fora, a noite já estava alta. O vento acalmara um pouco, no céu despontavam estrelas reluzentes. Nós caminhamos lado a lado e disse: quarto.

- Eu poderia perfeitamente dormir no chão junto aos outros, no mesmo

Com voz sonolenta, o senhor Uehara se limitou a dizer:

$-\operatorname{Sim}$.

- Você queria ficar a sós comigo não é? Não é mesmo? - eu lhe disse isso com um pequeno sorriso.

- Por isso é que não dá! - ele entortou a boca num sorriso amarelo. Nesse momento, tive a consciência de que eu estava sendo amada por ele.

- Você bebe saquê em demasia, não? Toda noite é assim?

- Ah! todos os dias, desde manhã cedo.

- $O$ saquê é gostoso?

- Não é gostoso.

Senti arrepios por todo o corpo ao ouvi-lo falar assim.

- Como está o seu trabalho?

- Não adianta. Tudo o que escrevo agora é estúpido e me parece bobagem, só me entristece. É o crepúsculo da vida. O crepúsculo da arte. $O$ crepúsculo da humanidade. Isto também é pedante.

- Utrillo $^{72}$.

Disse-lhe eu, quase inconscientemente.

- Ah, Utrillo. Dizem que ele ainda está vivo, não é? Uma vítima do álcool. Ele é um cadáver, não é isso? Os seus quadros, desses últimos dez anos, são incrivelmente vulgares, não têm nenhuma importância, sem exceção.

- Não é somente Utrillo, não é? Todos os outros mestres também...

- Sim, enfraquecimento. Porém, mesmo as mudas novas enfraquecem na condição de mudas. Geada. Frost. Parece que caiu uma geada fora de época, no mundo todo.

72 Maurice Utrillo (1883-1955). Pintor francês. Utilizou muito a cor branca para retratar o cenário do recanto suburbano. 
O senhor Uehara colocou as suas mãos sobre os meus ombros, e meu corpo ficou envolvido pela manga da sua vestimenta. Não o repeli. Pelo contrário, aconcheguei-me a ele e andei sem pressa.

Galhos de árvores plantadas à beira da estrada, galhos desfolhados finos e pontudos pareciam espetar o céu noturno.

- Como são lindos os galhos das árvores. - disse eu, como num monólogo. hesitante.

- Sim, há harmonia entre a flor e os galhos escuros. - disse ele, um tanto

- Não, senhor. Eu gosto dos galhos desprovidos de flores e folhas e brotos. Ainda assim, eles estão perfeitamente vivos. Eles diferem dos galhos secos.

- Você quer dizer que somente a natureza não enfraquece? - assim dizendo, deu diversos espirros violentos.

- Não seria resfriado?

- Não, não é nada disso. Tenho um estranho hábito: quando a embriaguez atinge o ponto de saturação, imediatamente começo a espirrar desse jeito. É como um barômetro da minha intoxicação, entende?

- E o amor?

- O que tem o amor?

- Há alguém? Alguém que você tenha amado até o ponto de saturação?

- O que é isso! Não zombe de mim. As mulheres são todas iguais. Elas são muito complicadas. "Guilhotina, guilhotina, zuuuup." Na verdade há uma, quero dizer, metade de uma.

- Você leu as minhas cartas?

$-\mathrm{Li}$.

$-E$ a resposta?

- Eu detesto os nobres. Existe neles sempre uma espécie de arrogância insuportável. Seu irmão Naoji é um grande sucesso para um aristocrata; mas, de vez em quando, ele mostra repentinamente uma impertinência que dificulta a convivência. Sou filho de lavradores do interior, sabe? E, quando passo perto de um riacho como este, invariavelmente me vem a lembrança da minha infância, do córrego da minha terra natal em que pescava carpas e apanhava lambaris na peneira, e me dá um aperto no coração.

Caminhávamos ao longo da margem do riacho que corria com um leve ruído em meio à escuridão.

- Vocês nobres, além de serem absolutamente incapazes de compreender esse nosso sentimentalismo, ainda nos desdenham.

- E Turgueniev? ${ }^{73}$

- Aquele sujeito é um nobre. Por isso é que eu o detesto.

73 Ivan Sergeevich Turgueniev (1818-1883). Escritor russo de origem aristocrática, autor de "Diário do caçador". 
- Mas, e o Diário do Caçador...

- Humm, somente esse conto não é tão ruim.

- Nesse conto, ele capta o sentimento da vida rural.

- Esse autor é um nobre rural - vamos fazer um acordo por aqui.

- Agora, eu também sou uma moça do interior. Estou cultivando uma horta, sabe? Uma garota pobre do interior. filho meu?

- Você ainda gosta de mim? - o tom de sua voz era brutal. — você quer um

Eu não respondi.

Seu rosto aproximou-se do meu com a força de uma rocha e fui beijada com fúria. Seus beijos revelavam o desejo sexual. Derramei lágrimas recebendo seus beijos, amargas como a vergonha por sentir-me humilhada. Elas jorravam dos meus olhos e molhavam-me o rosto.

Novamente, continuamos a andar lado a lado. Ele me disse:

-Cometi uma falha. Eu me apaixonei. - e riu

Mas eu não conseguia sorrir. Franzi o cenho, mordendo os lábios.

"Não havia jeito." Se expressasse em palavras, aquele seria o meu sentimento. Depois, eu percebi que arrastava o tamanco e caminhava de modo rude. final?

- Cometi uma falha - disse-me novamente o homem. - vai continuar até o

- Não seja fingido.

- Sua malvada!

O senhor Uehara bateu no meu ombro, e novamente deu um violento espirro.

$\mathrm{Na}$ casa daquele tal de senhor Fukui, todos pareciam estar dormindo.

- Telegrama! Telegrama! senhor Fukui, telegrama - berrou senhor Uehara, e depois bateu à porta da varanda. masculina.

- Ah, é você, Uehara? - do interior da residência ouviu-se uma voz

- Eu mesmo. "Príncipe" e "Princesa" solicitando uma noite de pousada. Quando se faz tanto frio assim, só espirro e até a jornada do amor torna-se uma comédia.

A porta da frente foi aberta por dentro. Um homem baixo, careca, acima de cinqüenta anos e trajando um pijama colorido, recebeu-nos com um sorriso meio envergonhado.

- Por favor.

O senhor Uehara disse somente isso, e sem nem mesmo tirar o sobretudo, foi adentrando na casa sem cerimônia. 

Venha.

- O seu "atelier" faz muito frio. Vou utilizar o quarto de cima, está bem?

Ele pegou a minha mão, seguiu até o final do corredor, subiu as escadas, entrou no quarto escuro e ligou o interruptor do canto do quarto.

- Parece uma sala de algum restaurante, não acha?

- Sim, gosto de novos-ricos. Mas, é um desperdício para um péssimo pintor como Fukui. Mas ele tem uma sorte dos diabos; está imune aos desastres naturais como incêndio. É melhor usufruí-la. Bem, vamos dormir, vamos dormir.

Como se estivesse em sua própria casa, ele abriu sem cerimônia o armário, retirou os acolchoados, estendeu-os e ordenou-me:

- Durma aqui. Vou-me embora. Amanhã cedo, virei buscá-la. O banheiro fica logo à direita, descendo a escadaria.

Desceu a escadaria apressadamente, como se tivesse quase despencando. Depois, o local permaneceu em total silêncio.

Desliguei a luz, tirei o casaco de veludo feito com o tecido estrangeiro que papai havia me dado, tirei somente a faixa do quimono, deitei assim mesmo. Sentia o meu corpo pesado, provavelmente devido à ingerência do saquê acrescido ao meu cansaço, e logo adormeci.

Não sei quando aconteceu, mas, ao despertar, notei que ele se encontrava deitado ao meu lado... Durante quase uma hora, resisti calada, com todas as minhas forças.

Subitamente, tive pena dele, e me entreguei a seus braços.

- Se eu não agir assim, o senhor não sossega, não é mesmo?

- Bem, é mais ou menos isso... sangue?

- Mas, o senhor não está bem de saúde, não é? Não andou expelindo

- Como sabe? Na verdade, ocorreu isso, outro dia. Mas não disse a ninguém.

- Pois este é o mesmo cheiro que mamãe exalava antes do seu falecimento.

- Bebo, pensando em morrer. Não agüento a tristeza de viver. Não se trata de extravagâncias como solidão, desolação. É tristeza. Quando entoam nos quatro cantos suspiros de lamentações, é impossível sentir uma felicidade particular, somente da gente. Quando o homem se atinar de que, enquanto estiver vivo, jamais poderá alcançar a felicidade ou uma glória própria, o que se há de fazer? Esforço tudo isso apenas alimentará as bestas esfomeadas. Há gente miserável em excesso! Estou sendo falso?

- Não, senhor.

- Somente o amor. Justamente como você escreveu em sua carta.

- Ah, sim?

Aquele meu amor já tinha se apagado.

Amanheceu. 
O quarto clareou de leve e contemplei atentamente o rosto da pessoa que dormia ao meu lado. Tinha o rosto de quem morreria em breve. Tinha a expressão fatigada.

A face de um mártir. Louvável mártir.

Meu homem. Meu arco-íris. My child. Malvado. Espertinho.

Como se não houvesse outro nesta vida, tão belo, tão belo me pareceu seu rosto, e como se o meu amor por ele tivesse ressuscitado e se renovado no meu peito, beijei-lhe, acariciando os seus cabelos.

Triste, triste realização do amor.

Com os olhos cerrados, o senhor Uehara me abraçou, dizendo:

- Sentia-me desprezado por ser filho de lavrador.

Não me separarei mais dele.

- Sou feliz agora, viu? Apesar das lamentações que se entoam nos quatro cantos. Essa minha felicidade encontra-se no ponto de saturação. Sou feliz a ponto de espirrar.

Ele riu:

- Puxa, como já está tarde! É crepúsculo.

- É manhã.

Naquela manhã, meu irmão Naoji havia se suicidado. 


\section{Capítulo VII}

\section{Testamento de Naoji}

Mana.

Não dá mais. Irei primeiro.

$\mathcal{N}$ ão compreendo nem um pouco por que devo continuar vivendo.

Aqueles que quiserem continuar vivendo, que vivam.

Assim como um homem tem direito de viver, ele também deve ter o direito de morrer.

Esse meu modo de pensar não tem nada de novo; apenas os homens é que, estranhamente, temem dizer em voz alta uma coisa tão primitiva e natural.

Quem quiser continuar a viver, deve fazê-lo a qualquer custo, com energia, até onde for capaz, e isso é louvável. Aquilo que chamam de coroa da glória humana, deve estar mais ou menos aí. Entretanto, estou convencido de que o suicídio tampouco se constitui um pecado.

Eu, a erva daninha que sou, tenho muita dificuldade em viver no ar e na luz deste mundo. Falta-me alguma coisa para continuar a viver. Falta-me algo. Consegui viver a muito custo até agora.

Quando entrei no colégio, ao defrontar-me pela primeira vez com amigos fortes e rijos como plantas crescidas numa classe social completamente diferente daquela onde me criaram, vi-me impelido pela força deles, mas, para não ser deixado para trás, tive de recorrer aos entorpecentes, e resisti freneticamente. Mais tarde, quando me tornei soldado, era como se o ópio fosse o meu último recurso para continuar a viver. Para a mana, deve ser difícil compreender o meu sentimento.

Queria tornar-me vulgar. Queria ficar forte, não, queria me tornar brutal. $E$ achei que este seria o único meio para me tornar amigo do povo, só saquê não adiantava. Eu precisava estar numa eterna vertigem. Não havia outra saída senão tomar drogas. Eu tive de esquecer minha casa, eu tive de renegar o sangue de meu pai, tive de recusar a meiguice de mamãe, tive de ser frio com a mana. Se não agisse assim, não conseguiria misturar-me ao povo, assim pensava eu.

Eu me tornei vulgar. Passei a dizer palavras de baixo calão. Entretanto, metade disso - não, sessenta por cento - não passava de desprezivel embuste. Era um trabalho desastrado. Para o povo, eu não passava de um homem pedante e relapso. Eles nunca relaxavam comigo e não ousavam brincar de fato comigo. Por outro lado, seria impossivel para mim retornar ao ambiente que abandonei. Apesar de minha vulgaridade de sessenta por cento ser falsa, os quarenta por cento restantes atuais são autênticos. Revolve o meu estômago a elegância intolerável da chamada alta classe. Aqueles distintos cavalheiros, aqueles eminentes cidadãos, como eles são denominados, ficariam revoltados com meus maus modos e logo colocarme-iam no ostracismo. Com certeza, eles me expulsariam do seu meio. Sem poder retornar ao mundo que eu reneguei, do povo eu só recebi um lugar no auditório cheio de maldade e idiotice.

A verdade é que, em qualquer sociedade, uma erva daninha como eu, sem vitalidade e cheia de defeitos está predestinado a perecer. Sujeito que não tem ideologia ou o que pode assim ser chamado; mas eu também tenho algo a oferecer. Eu sinto a impressionante pressão das circunstâncias que me impede de viver.

"Todos os homens são iguais." 
Afinal, é isso ideologia? Acho que o inventor dessa frase estranha não foi um religioso, nem filósofo, nem artista. Deve ter Grotado das tabernas freqüentadas pelo povo. A expressão alastrou-se como um verme, sem saber da sua origem, e sem que ninguém em especial tivesse começado a falar. Nasceu do nada, envolvendo todo o mundo, tornando-se constrangedora para todos.

Essa frase estranha nunca teve nenhuma relação com a democracia nem com marxismo. É apenas uma frase que, sem a menor dúvida, foi utilizada numa taberna, por um homem feio que a lançou para outro 6onito. Foi apenas uma irritação ou ciúme puro. Nada de ideologia ou coisa que o valha.

Contudo, esse berro ciumento de taberna, com feição esquisita de ideologia, andou infiltrando-se entre o povo, e, apesar de não ter nenhuma relação com a democracia ou com o marxismo, aproximou-se em surdina das ideologias politicas e econômicas, criando uma sórdida e insuportável confusão. Até Mefisto teria hesitado, face à própria consciência, em praticar uma arte como a de substituir a ideologia por uma frase tão absurda.

"Os homens são todos iguais!"

Que frase mais abjeta. Ao mesmo tempo em que humilha a todos, não poupa sequer aquele homem que a profere. E sem nenhum orgulho, parece anular todo o esforço. O marxismo proclama a superioridade do trabalhador. Mas não diz que eles são todos iguais. A democracia proclama a dignidade do individuo. Mas não diz que eles são todos iguais. Só o rufião diz: sim, apesar de toda a sua arrogância, pode-se ver que você é igual a mim.

Por que ele diz "igual"? São pode dizer "superior"? A vingança do espírito do escravo!

Essa frase é bem ordinária e obscena. As pessoas temem umas as outras, os princípios são violados, o esforço é ridicularizado, a felicidade negada, a beleza conspurcada, a honra derrubada... Eu acredito que a "inquietação do século" originou-se dessa frase bastarda.

Embora eu ache essa expressão medonha, também eu fui intimidado por ela, amedrontado e trêmulo, senti-me envergonhado de tudo que tencionava fazer. Fui tomado pela ansiedade e impotência para agir. Eu queria só uma paz momentânea e me entreguei ao álcoole à droga. E tudo se perdeu.

Eu devo ser fraco. Quero ser uma erva daninha com alguma falha importante. "Por que ele está racionalizando? Ele sempre gostou de vadiar! Não passa de um 6oa-vida, indolente, sujo e egoísta." Diria, talvez, zombeteiro, o referido rufião. $\mathcal{E}$ até agora, diante de tais palavras, eu apenas me mostrava envergonhado e negava de um jeito qualquer; mas, já que decidi morrer, quero deixar lavrada uma palavra de protesto.

Maninha, por favor, acredite em mim.

Mesmo vadiando, não sentia nem um pouco de prazer. Talvez eu fosse impotente em relação à diversão. Meu desejo era tornar-me independente da sombra do nobre, e enlouqueci, levei uma vida ociosa e sucumbi.

Maninha, afinal, nós temos culpa? É, por acaso, nossa culpa termos nascido na aristocracia? Só por termos meramente nascidos nessa família, somos condenados a passar eternamente nossa vida em humilhação, a mendigar o perdão como os familiares de Judas? ${ }^{[74]}$

Eu deveria ter morrido antes. Não o fiz por uma única razão: meu amor por mamãe. Quando eu pensava nela, era incapaz de morrer. Assim como todo o homem tem o direito de viver livremente, ele também tem o direito de morrer quando The for aprazivel, mas, enquanto mamãe estava viva, achei injusto recorrer a esse direito, pois significaria matá-la também.

74 Judas Escariotes. Um dos doze apóstolos de Jesus, que o traiu e, depois, suicidou-se. 
Agora, mesmo que eu morra, não há quem se lamente tanto. Não, mana, eu sei quanta tristeza a minha morte ocasionará a maninha. Porém, vamos deixar de lado o falso sentimentalismo. Indubitavelmente, vocês chorarão ao saberem da minha morte, todavia se pensarem no sofrimento da minha vida e na minha alegria de me libertar completamente do sofrimento de viver esta vida odiosa, com certeza a tristeza de vocês irá se dissipar aos poucos.

Quem censurar o meu suicídio só por gosto de julgamento, com ar de superioridade (sem oferecer-me ajuda), dizendo para continuar a vida a todo o custo, há de ser um grande homem, que está à altura daquele prodigioso homem com capacidade de sugerir a Sua Alteza que abra uma quitanda.

Mana, é melhor que eu morra. SNão tenho capacidade de continuar vivo. Não tenho forças para lutar contra os homens por causa do dinheiro. Nem sou capaz de ser dependente dos outros. Mesmo quando saio em companhia do senhor Vehara, para beber, sempre pago a minha conta. O senhor Vehara sempre me criticava dizendo que eu era um sovina orgulhoso da aristocracia, mas não era por causa do orgulho que eu pagava. E, sim, porque me afligia beber e comer abraçado às mulheres com o dinheiro do trabalho dele. Era por respeitar o trabalho literário do senhor Vehara, mas isso era uma mentira. Pois, na verdade, nem eu me compreendo. O que me perturba é quando a minha conta é paga por outrem. 'É intolerável, doloroso e repugnante a diversão bancada por outras pessoas, especialmente se o dinheiro é oriundo tão somente do próprio esforço.

E, assim, passei a retirar da minha própria casa dinheiro e objetos de valor, causando sofrimento a mamãe e a você. SNão tive nenhum prazer nisso e mesmo o projeto de atividade editorial não passou de embuste para esconder a minha estupidez. N Nunca tive verdadeiramente nenhuma intenção real de me tornar um editor. Mesmo que eu a tivesse tido, não poderia ganhar dinheiro de forma alguma porque sou incapaz de explorar os outros - por mais que eu seja estúpido, consigo perceber isso.

Mana, nós empobrecemos. Enquanto eu estava vivo e tinha meios, sempre pensei em oferecer comida e bebidas para outros, mas agora nós podemos somente sobreviver com a conta sendo paga pelos outros.

Mana, por que haveria eu de continuar vivendo? Já não dá mais. Eu morrerei. Possuo um veneno que me fará morrer sem sofrimento. Eu o consegui quando era soldado e tenho-o mantido sempre comigo.

A mana é linda (eu sempre me orgulhei de ter uma mãe e irmã lindas) e inteligente, por isso não me preocupo com nada em relação a você. N Não tenho nem mesmo qualificação para me preocupar com você. $\mathscr{E}$ vergonhoso o que sinto - como um ladrão que simpatiza com sua vítima! Tenho certeza de que a mana irá se casar. Você terá filhos e conseguirá viver apoiada ao seu marido.

Mana, tenho um segredo. Por longo tempo tratei de ocultá-lo bem, até mesmo na frente de Gatalha. $\mathcal{N}$ ão tenho pensado em outra coisa senão numa pessoa, e não sei quantas vezes acordei chorando, depois de vê-la em sonhos.

Eu não seria capaz de revelar o nome dela a ninguém, nem que o mundo acabasse. Como resolvi encurtar a minha vida, pensei em revelar pelo menos para a mana. De qualquer modo, o meu medo impede de revelar o nome dela. Porém, eu sinto que se eu morrer mantendo o segredo absoluto no fundo do meu peito, bem guardado, sem revelar a ninguém, tenho a impressão de que, mesmo se o meu corpo for incinerado, o meu peito permanecerá intacto, sem queimar. Esse pensamento tem-me atormentado e, para apaziguar a minha inquietação, resolvi dar-lhe alguns indícios vagos, como numa novela de ficção. Mesmo que eu chame isso de ficção, eu tenho certeza de que a mana reconhecerá imediatamente de quem eu estou falando. Esse indício nem chegará a uma novela de fiç̧ão, mas a um simples disfarce, como o de utilizar um nome fictício.

Será que a mana conhece essa pessoa?

A mana deve conhecer essa pessoa, mas, talvez, ainda não a tenha encontrado. Ela é um pouco mais velha que você, e têm as pálpebras sem dobras, os olhos repuxados, típicos de japonesa; ela tem os cabelos 
naturais, que nunca foram submetidos ao permanente, e o seu penteado é no estilo conservador japonês, cabelo todo puxado para trás. As vestimentas dela estavam gastas, porém, limpas. Ela estava sempre com postura distinta e asseada. Ela é esposa de um pintor de meia idade que se tornou célebre subitamente, no pós-guerra, produzindo uma sucessão de quadros modernos. Sua esposa mantém-se sempre sorridente, fingindo indiferença em relação ao comportamento brutal e conturbado do seu marido.

Eu me levantei.

- Bem, eu preciso ir embora. dizendo:

Ela também se levantou, sem qualquer menção de reserva, aproximou-se de mim e encarou-me,

$$
\text { - Por quê? }
$$

A sua voz estava em timbre comum. Ela ergueu a cabeça, pendendo um pouco para o lado, como se estivesse em dúvida, olhando diretamente para dentro dos meus olhos. No sua feição, não havia malícia, nem pretensão. SNormalmente, quando os meus olhos encontram os de uma mulher fico confuso, eu me embaraço e desvio do seu olhar; mas, naquele momento, não senti nenhum acanhamento. Durante sessenta segundos ou mais, os nossos rostos permaneceram separados pela distância de trinta centímetros. Enquanto eu fixava o meu othar ao dela, senti-me extremamente feliz. Depois, ela me disse com um sorriso:

- Mas... ele voltará logo - Disse ela com o rosto sério.

Subitamente, ocorreu-me que o que a expressão daquele rosto poderia resumir-se ao que as pessoas chamam "honestidade". Não se tratava de virtude ditada pela cartilha da moral. Não teria sido assim graciosa a virtude original expressa pela palavra honestidade?

- Voltarei outro dia.

- Sim?

Toda nossa conversa do começo ao fim foi inocente. Uma tarde de verão, fui procurar o pintor em seu apartamento, mas ele estava ausente. Sua esposa sugeriu-me esperá-lo, porque ele não demoraria a retornar. Aceitei sua sugestão, entrei na sala e, durante aproximadamente trinta minutos, fiquei a ler revistas. Como não tinha sinal do seu retorno, levantei-me e me despedi. Foi somente isso que houve. Mas, nesse dia e hora, eu me senti dolorosamente apaixonado pelos olhos dessa senhora.

Poderia dizer "sentimentos nobres"? Dentre os nobres do nosso círculo - com exceção da mamãe -, digo que jamais vi uma expressão dos olhos tão "honesta".

Depois disso, ao entardecer de um dia de inverno, fiquei impressionado com o seu perfil. Eu estive bebendo desde a manhã com o pintor em seu apartamento, enquanto nós ríamos e fazíamos críticas severas aos pseudo-intelectuais do Japão. De repente, o pintor caiu no sono e, logo depois, já estava roncando pesadamente. Eu também me deitei e comecei a cochilar, quando fui coberto delicadamente. Abri os olhos com o leve roçar do cobertor e vi que o céu do entardecer invernal em Tóquio estava límpido e azul. Visualizei a esposa do pintor sentada calmamente junto à janela com a filha no colo. Os contornos do seu perfil delicado ressaltavam com o fundo azul do céu pálido e longínquo, cujas silhuetas emergiam brilhantes como nas pinturas de perfis do tempo da Renascença. Ela colocou o cobertor carinhosamente, sem malícia nem interesse. Não teria a palavra "humanidade" readquirido seu sentido exato, quando utilizada numa ação como essa? Ela tinha agido quase inconscientemente, ditada pelo natural sentimento de solidão. E ela contemplava o distante céu, numa calma postura, idêntica à das pinturas.

Eu fechei os olhos, senti o desejo da paixão a ponto de enlouquecer, os meus olhos trans6ordaram de lágrimas, encobri o rosto com o cobertor para me esconder. 
Maninha, o motivo da visita à casa desse pintor foi, a princípio, o sentimento inebriante causado pelo toque singular dos seus trabalhos, bem como a paixão fanática que neles ocultava; contudo, à medida que o nosso relacionamento aprofundava, a sua falta de cultura, sua irresponsabilidade e sua sordidez me decepcionaram. Em oposição, fui atraído pela beleza dos sentimentos da sua esposa; não, apaixonei-me por uma pessoa de afeições verdadeiras e, na esperança de poder ver a figura dessa esposa e poder captar ao menos de relance o seu othar, comecei a freqüentar a casa desse pintor.

Eu estou convencido de que se, por acaso, emanar da obra dele algo por infimo que seja, de nobreza artística, provavelmente será o reflexo da meiguice da esposa.

o pintor - eu quero dizer exatamente o que eu sinto. - É um hábil mercador e não passa de um alcoólatra, amante de farras. Quando necessita de dinheiro para a sua diversão, Limita-se a manchar grosseiramente as telas, levando vantagem da tendência da sua popularidade e, posando de grande artista, vende a peso de ouro todos os seus quadros. Ele possui a rudeza de um caipira interiorano, uma confiança estúpida e um faro comercial velhaco - é só isso.

Certamente, ele não deve compreender a pintura de outros artistas, tanto estrangeiros como japoneses. Além do mais, eu duvido que ele entenda o que ele mesmo pinta. Com o intuito de obter dinheiro rápido para as suas diversões, ele salpica freneticamente as tintas em suas telas.

O mais assustador é que ele não aparenta nenhum remorso em relação ao lixo que produz, nem demonstra vergonha, nem terror.

De fato, o que ele sente é orgulho disso. Como é uma pessoa que nem compreende a sua própria pintura, obviamente ele não poderá avaliar a qualidade dos trabalhos alheios. Longe disso - e como ele critica os outros, e como critica...

Em outras palavras, embora da boca para fora ele diga do sofrimento de viver como um decadente, ele não passa de um matuto do interior que se deslumbrou pela metrópole, conseguindo galgar o sucesso na escala de uma fama quase inimaginável, até para os seus próprios olhos. Esse sucesso repentino inflou o seu ego e, agora, ele passa o seu tempo divertindo-se como um deslumbrado.

Certo dia, eu the disse: "Enquanto os meus amigos se divertem e vadiam, fico a estudar sozinho, o que me deixa constrangido e horrorizado, por isso, faço-lhes companfia e me divirto, ainda que sem nenhuma vontade".

O pintor de meia idade respondeu:

- O quê? É isso o que você chama modos de um nobre? Isso me revolve o estômago. Quando vejo os outros se divertindo, sinto que estou em desvantagem se não brincar também, e me junto aos foliões!

Diante da impassividade do pintor, a partir de então, comecei a sentir um desprezo enorme por ele, do fundo de minha alma. $N$ a libertinagem dele não existe tormento. Pelo contrário, ele se vangloria do seu estúpido prazer infantil. Ele não passa de um debochado legítimo e de um idiota hedonista.

Eu poderia citar inúmeras outras coisas desagradáveis a respeito desse artista, mas, afinal de contas, isso não interessa à mana. Além do mais, estou prestes a morrer. Entretanto, ao lembrar-me da longa convivência com esse dito pintor, sinto saudades e vontade de farrear em companfia dele, pelo menos mais uma vez. Não-lhe guardo nenhum rancor dele. Esse artista tem muitas qualidades boas e, no fundo, ele se sente só. $\mathcal{N a a ̃ o ~ d i r e i ~ m a i s ~ n a d a . ~}$

Gostaria de deixar a mana ciente do tormento que vivi levado pela paixão pela esposa desse pintor. Fiquei sem saber o que fazer. Por isso, não há necessidade de a mana, depois da minha revelação, cometer a desagradável indiscrição de revelar isso a alguém, a pretexto de satisfazer o desejo que em vida tinha o irmão. Ficarei feliz em compartilhar o meu com você mana, e peço-lhe que o mantenha em sigilo. $\mathcal{E}$, se me 
permite, deixe-me dizer se a mana compreender, mais do que ninguém, através dessa vergonhosa confissão, o sofrimento e calvário que foi a minha existência até hoje, ficarei feliz.

Um dia sonhei ter trocado aperto de mãos com a esposa do pintor. Soube que ela também gostava de mim, desde há muito tempo. Mesmo depois de ter despertado do meu sonho, o calor dos seus dedos permanecia na palma da minha mão. Convenci-me de que teria de me contentar com isso e me resignar. Não era a moralidade ou coisa que o valha que me intimidava, mas o que me aterrorizava era aquele pintor meio louco - não, completamente louco. Pensei em resignar-me, quis desviar o fogo dessa paixão para outra direção, e me lancei incansavelmente para orgias selvagens com toda a espécie de mulheres que estavam disponiveis, ignorando quem quer que fossem. Cheguei a um ponto em que até o pintor olhou-me com olhar de reprovação. Eu queria, de certa forma, libertar-me do encanto da sua esposa, esquecê-la e reduzir o que sentia a nada. Mas, foi tudo em vão. Eu sou do tipo de homem que consegue amar somente uma mulher. Posso declarar positivamente que nenhuma vez achei lindas ou adoráveis as minhas amigas, exceto ela.

Mana, antes de morrer, gostaria de escrever o nome dela, uma única vez:

... Suga.

É o nome da referida senhora.

Ontem, cheguei a essa casa de campo em companfia de uma dançarina, a quem não tenho muito afeição (ela é de uma estupidez congênita). Quando cheguei, nem tinha sonhado que eu morreria esta manhã. Pensava em morrer logo, algum dia desses, só isso. Obedecendo à insistência da dançarina, de querer viajar, acatei a idéia dela e, cansado que estava de Tóquio, resolvi repousar dois ou três dias nesta casa, juntamente com essa estúpida mulher. $\mathcal{N a}$ verdade, senti-me meio embaraçado com a sua presença, e, logo que cheguei, você partiu, em seguida, para a casa de uma amiga sua em Tóquio. Foi então que, de súbito, ocorreu-me a idéia: "Se vou me matar, agora é a hora propícia".

Desde há muito tempo, eu queria morrer na sala dos fundos da casa em Nishikata. Sempre detestei a idéia de morrer em locais públicos ou no campo e o meu corpo ser tocado por curiosos. Mas a nossa casa em $\mathcal{N}$ ishikata passou para outras mãos. Não tive opção, a não ser morrer nesta casa de campo. Ao imaginar que a mana seria a primeira pessoa a saber de minha morte, que se assustaria e se apavoraria, sentia um imenso peso no coração, que me impedia de me suicidar na sua presença.

$\mathcal{E}$, agora, surgiu a grande chance! A mana ausente e, em seu lugar, tenho aqui uma dançarina extremamente obtusa que servirá para descobrir o meu corpo.

Ontem à noite, bebemos saquê juntos, coloquei a mulher para dormir no quarto de cima, estendi a coberta na sala de baixo, onde faleceu mamãe, e, então, comecei a escrever esta miserável memória.

Mana, não tenho alicerce para esperanças. Adeus.

Em ultima análise, minha morte é natural - pois o homem não morre só por um ideal.

Tenho um pedido a the fazer, o que me deixa acanhado. Você se lembra do quimono de cânhamo que mamãe nos deixou? A mana reformou-o de modo que eu pudesse usá-lo no verão do ano seguinte, lembra? Por favor, coloque-o dentro do meu caixão. Eu queria vesti-lo.

Começa a amanhecer. Eu tenho feito você sofrer há muito tempo.

Adeus.

Minha embriaguez de ontem à noite passou inteiramente. Morro só6rio.

Mais uma vez, adeus.

Mana.

Eu sou, acima de tudo, um nobre. 


\title{
Capítulo VIII
}

\author{
Sonhos.
}

Todos vão se afastando de mim.

Após cuidar do funeral de Naoji, permaneci morando sozinha na casa de campo durante um mês de inverno.

\author{
Então, eu escrevi para o senhor Uehara. Provavelmente seria a última carta \\ escrita com uma alma límpida como a água.
}

\section{Quarta carta}

Pelo visto, o senhor também me abandonou. SNão, parece-me que gradualmente o senhor vai me esquecendo.

Mas eu estou feliz. Consegui engravidar, conforme o meu desejo. Tenho a impressão de que perdi tudo, mas a pequenina vida que palpita no meu ventre constitui uma fonte de alegria dentro da minha solidão.

Para mim, não foi nenhuma imprudência condenável. Esses dias passei a compreender por que, neste mundo, há coisas como guerra, paz, comércio, cooperativas, política. O senhor deve, por certo, ignorá-las. Por isso, o senhor será sempre infeliz. Eu the direi por que: essas coisas existem para que as mulheres dêem à luz filhos saudáveis.

Desde o começo, nunca tive intenção de confiar-me em seu caráter ou seu senso de responsabilidade. A única coisa que estava em jogo era tão somente o sucesso na aventura do meu único amor. Esse desejo foi concretizado e, dentro do meu coração, está silencioso como o pântano da floresta.

Eu acredito que venci.

Mesmo que Maria dê à luz o filho que não seja do próprio marido, se ela possuir brio de orgulho, então, mãe e filho se tornam santos.

Tenho a satisfação de ter gerado um bom filho, ignorando, impávida, velhos preceitos da moral.

Presumo que, desde o nosso último encontro, o senhor continue levando sua vida de decadência ou, como quer que chame, bebendo em companhia de senhoras e cavalheiros, entoando a canção "Guilhotina, guilhotina". Eu não tenho a intenção de the sugerir que desista de viver. Pois que isso também seja a forma de sua última batalha.

Não tenho mais o desejo de dizer: "Desista de beber, cuide da própria saúde, viva uma vida longa, realize trabalhos invejáveis", ou algumas dessas hipócritas injunções. Em vez de realizar "trabalhos invejáveis", o fato de levar uma existência dita imoral talvez venha, pelo contrário, a merecer, no futuro, alguma palavra de agradecimento.

Mártires. Mártires de um período de transformações morais, isso é o que certamente nós dois somos.

Afinal, onde será que está ocorrendo a revolução? Pelo menos ao nosso redor, a velha moral, impedindo a nossa passagem, continua de pé, sem mudar em nada. Ainda que as ondas da superfície do mar se revolvam, as águas profundas do fundo estão longe de experimentar a revolução. Permanecem adormecidas e imóveis, sem se incomodarem com as revoluções da superfície? 
Contudo, penso ter repelido a velha moral na primeira batalha desenvolvida até agora, ainda que em minúscula proporção. E pretendo lutar com a segunda e terceira batalhas juntamente à criança que irá nascer.

O fato de dar à luz o filho do homem amado e de criá-lo constitui a realização da minha própria revolução moral.

Mesmo que o senhor se esqueça de mim e, ainda que perca a vida bebendo, sinto que conseguirei viver firme até coroar a minha revolução.

Ainda outro dia, soube através de certa pessoa, em detalhes consideráveis, sobre sua personalidade deturpada; entretanto, quem me concedeu essa força foi o senhor. Quem colocou em meu peito o arco-íris da revolução foi o senhor. Foi também o senhor quem me deu motivação para viver.

Estou orgulhosa do senhor, e confie em mim, quero que a criança que está prestes a nascer também se orgulhe do senhor.

Filho bastardo e sua mãe.

Nós lutaremos eternamente contra a velha moral e meu filho e eu levaremos uma vida radiante como o sol.

Por favor, o senhor também prossiga a sua luta.

A revolução ainda não está, de mođo algum, completa. Serão necessárias mais e mais mártires nobres a lamentar.

$\mathcal{N}$ o mundo, as coisas mais belas são os seus mártires.

Quero the falar de um pequeno mártir.

Sr. Vehara.

Eu não tenho mais nada a pedir-lhe para mim mesma; mas, peço-the que o senhor seja complacente para com esse pequenino mártir.

Gostaria que sua esposa segurasse o meu filho nos seus braços, mesmo que fosse uma vez. E queria que o senhor me permitisse dizer-lhe o seguinte:

- Esta é a criança que Naoji secretamente teve com certa mulher.

Por que eu procedo assim? Isso é uma coisa que não posso dizer a ninguém. Nãa, nem eu mesma sei por que the peço isso. Entretanto, estou ansiando que o senhor me faça esse favor. Por favor, peço-lhe por amor ao pequeno mártir chamado $\mathcal{N a o j i . ~}$

Estou desagradando-lhe? Ainda assim, peço-lhe que me tolere. Pense que esta é uma das ofensas de uma mulher abandonada e que já the esqueceu. Peço-the of favor de atender-me.

Para M. C. "MY Comedian".

7 de fevereiro de 1947. 